Lívia Matheus Candian

\title{
ESTUDO DO POLIETILENO DE ALTA DENSIDADE RECICLADO PARA USO EM ELEMENTOS ESTRUTURAIS
}

Dissertação apresentada à Escola de Engenharia de São Carlos da Universidade de São Paulo, como parte dos requisitos para a obtenção do Título de Mestre em Engenharia de Estruturas.

Orientador: Prof. Dr. Antônio Alves Dias

São Carlos

2007 



\section{DEDICATÓRIA}

Dedico este trabalho aos meus pais,

Tadeu e Magaly, e à minha irmã Flora, pelo apoio e incentivo. 



\section{AGRADECIMENTOS}

Agradeço primeiramente a Deus, luz que me guia em todos os momentos.

Aos meus pais, Tadeu e Magaly, pelo amor, carinho, compreensão e dedicação de suas vidas, para a realização dos meus sonhos.

Ao professor Antônio Alves Dias, pela orientação, amizade e principalmente pelo incentivo e compreensão nas minhas escolhas.

Ao professor Libânio Miranda Pinheiro, pela amizade, paciência e dedicação para a concretização deste trabalho.

Ao professor José Augusto Marcondes Agnelli, pela grande ajuda na realização de alguns ensaios e principalmente pela simplicidade e disponibilidade na transmissão de conhecimentos.

Aos professores Benedito de Moraes Purquerio, Carlos Alberto Fortulan e Jonas de Carvalho, pela valiosa contribuição na discussão do projeto de pesquisa.

Ao professor Dirceu Spinelli, que cedeu seu laboratório, viabilizando a execução dos ensaios experimentais.

Aos empresários João Dimas Rodrigues Martins e Luciano Souza Osorio, que além de disponibilizarem as instalações de suas empresas para a confecção dos corpos-de-prova, cederam seus tempos, com discussão e ensinamentos a respeito do processamento dos materiais poliméricos.

Aos técnicos Lourival, Antônio Carlos e João Bernard, e ao pós-doutorando Cassius Ruchert, que além de ajudarem na realização dos ensaios experimentais, cederam tempo para a discussão desses ensaios.

Aos meus orientadores de iniciação científica, Maria Tereza Barbosa e Emil Sanches, que me direcionaram ao meio acadêmico.

Aos familiares que se preocuparam com minha felicidade e bem estar. Em especial ao meu padrinho, Luiz Carlos Abranches Penna.

Às amizades conquistadas nessa fase tão importante da minha vida: Larissa, Bia, Luciene, Fernanda, Érica, Sissi e Eduardo.

À Mariana, pela amizade verdadeira e à Marianinha, pelo carinho que sempre teve comigo. 
Aos amigos de turma: Dênis, Filipe, Saulo, André e Gustavo, pelos vários momentos de risos, principalmente nas festinhas de aniversário.

Aos grandes amigos "pentelhos", Marlos e Luis, que com sua alegria e amizade me ajudaram a superar momentos difíceis.

À Carlinha, Leila, Josi, Danielle, Roberta, Raquel e Isabel, amigas de verdade, pois a distância não interferiu na nossa amizade.

Aos amigos da Transpetro: Karina, Luciano, Anderson, Alexandre, Eline, Catiúcia, Alecsandra, Marilene, Pedro Paulo, Gilson, Bill, Gonçalves, Tavares, Santos, Saulo, Denner, Pinheiro e Sanandres.

Aos meus novos amigos campistas, Cláudia, Juliana, Marcelle, Rose e Marcelo, pelo carinho, amizade e pela força que sempre me deram.

À Karenina, uma grande amiga, que não só esteve presente em muitos momentos felizes, mas em muitos momentos importantes na minha vida.

À minha “irmãzinha” Gláucia, pela amizade e grande ajuda na realização dos ensaios experimentais.

Às minhas duas “mãezinhas” mineirinhas Iara e Marina, que além de me ensinarem os “afazeres do lar”, sempre se preocuparam comigo, com muito carinho e amizade.

Aos funcionários do Departamento de Engenharia de Estruturas e do Laboratório de Madeiras e de Estruturas de Madeira da EESC/USP, pela atenção e eficiência nos serviços prestados.

Ao CNPq, pela bolsa de estudos concedida, e à FAPESP, pelo auxílio financeiro que propiciou o desenvolvimento da pesquisa. 


\section{SUMÁRIO}

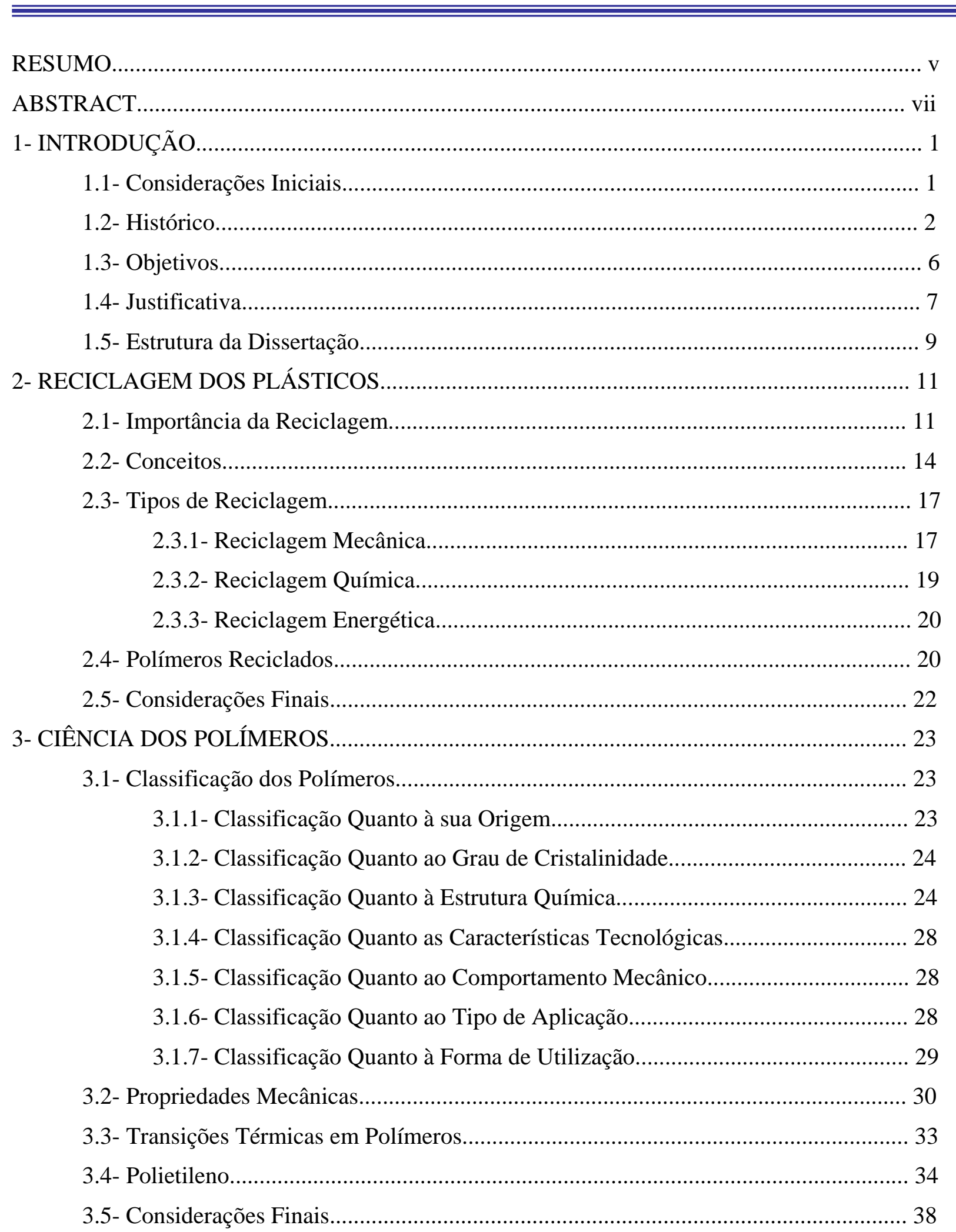




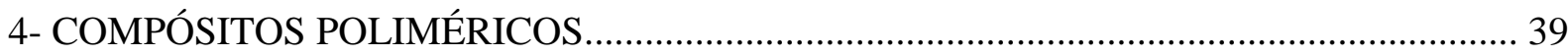

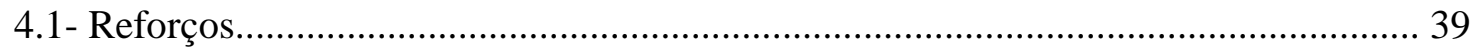

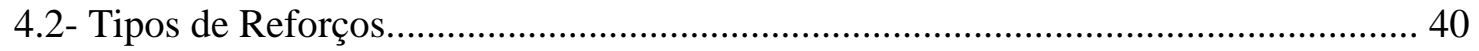

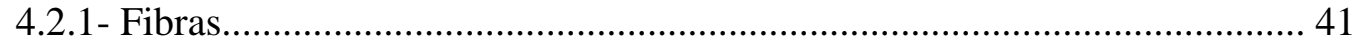

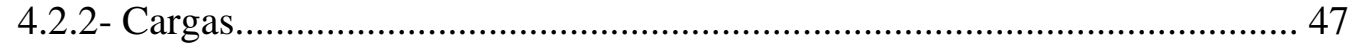

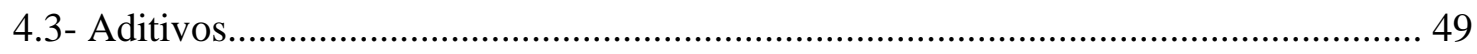

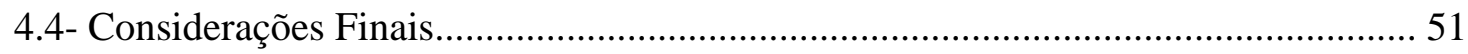

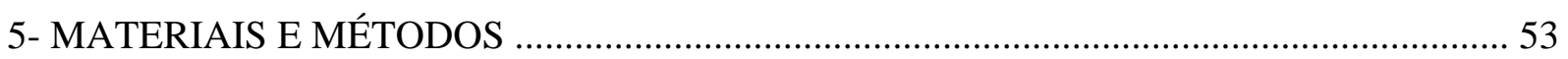

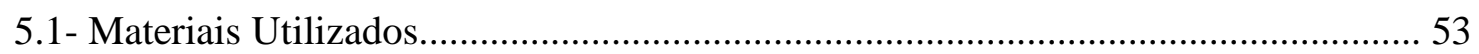

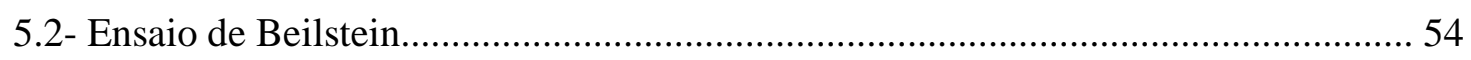

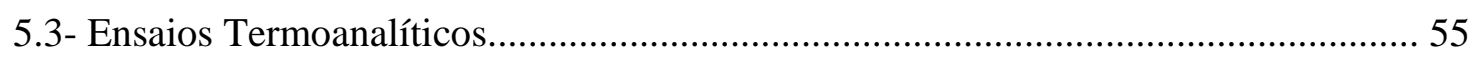

5.3.1- Calorimetria Exploratória Diferencial................................................................ 55

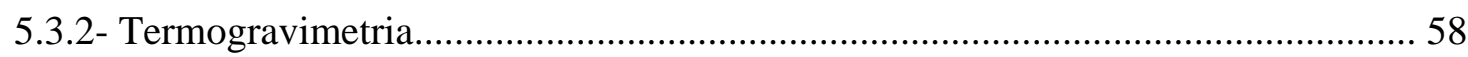

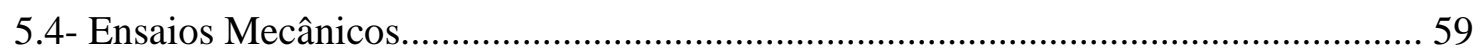

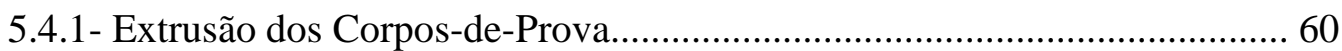

5.4.2- Usinagem dos Corpos-de-Prova.................................................................. 68

5.4.3- Ensaio de Tração.................................................................................... 70

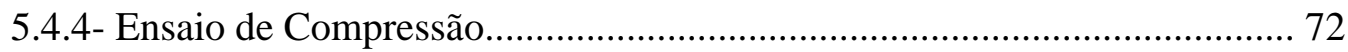

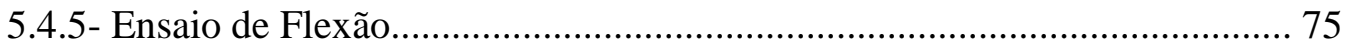

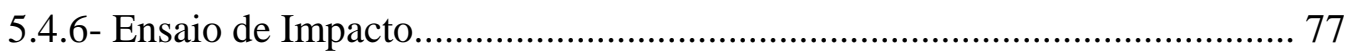

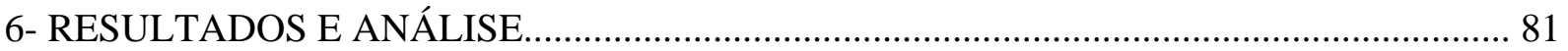

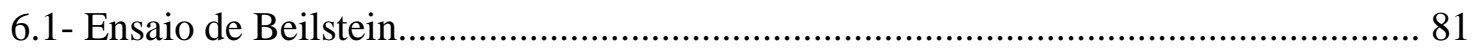

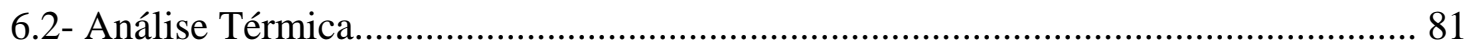

6.2.1- Calorimetria Exploratória Diferencial...................................................... 81

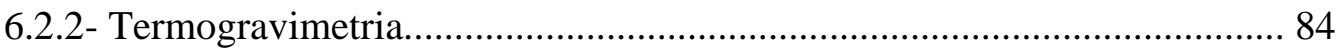

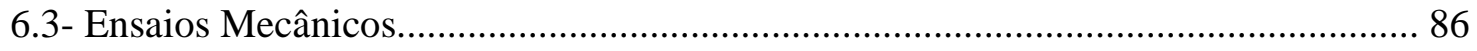

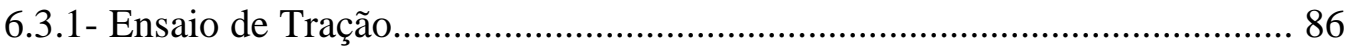

6.3.2- Ensaio de Compressão............................................................................. 90

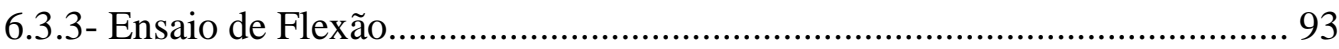

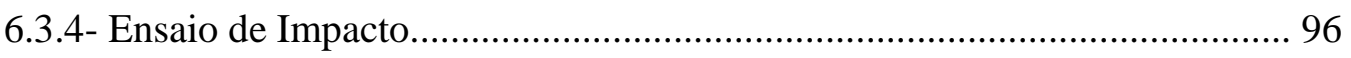

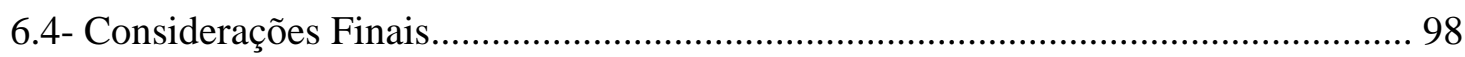

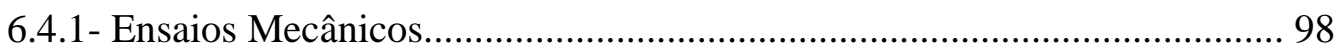


6.4.2- Utilização do PEAD em elementos estruturais.................................................... 100

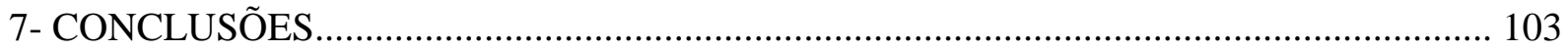

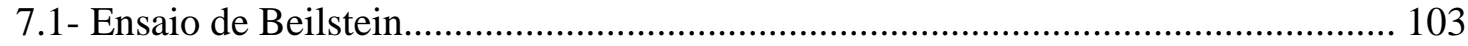

7.2- Calorimetria Exploratória Diferencial....................................................................... 103

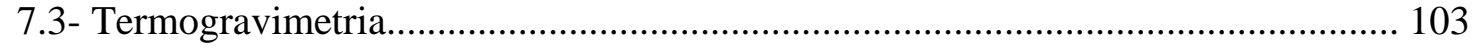

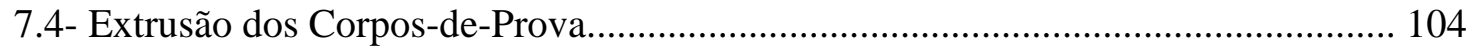

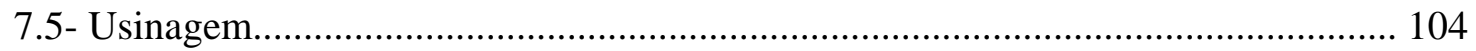

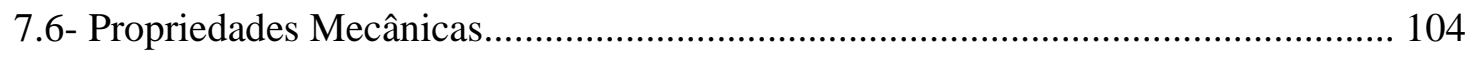

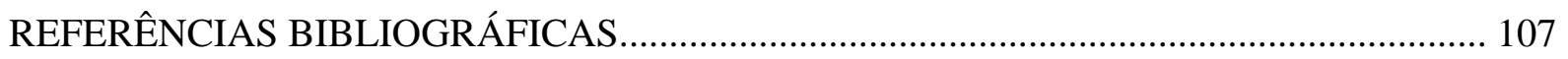

ANEXO A - CARACTERIZAÇÃO DOS POLÍMEROS RECICLADOS................................ 113

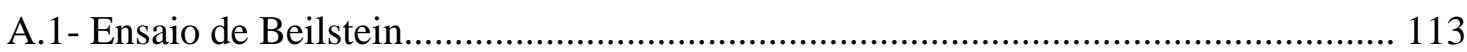

A.2- Análise Térmicas...................................................................................... 114

A.2.1- Calorimetria Exploratória Diferencial.................................................... 116

A.2.2- Termogravimetria.................................................................................. 119

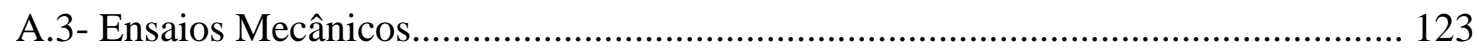

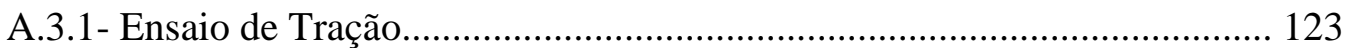

A.3.2- Ensaio de Compressão....................................................................... 126

A.3.3- Ensaio de Flexão................................................................................ 126

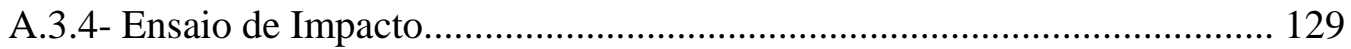

ANEXO B - RESULTADOS OBTIDOS NOS ENSAIOS …............................................... 133

B.1- Calorimetria Exploratória Diferencial...................................................................... 133

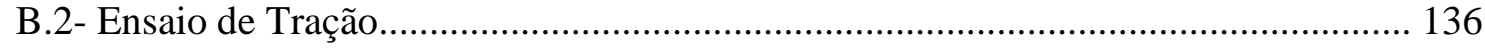

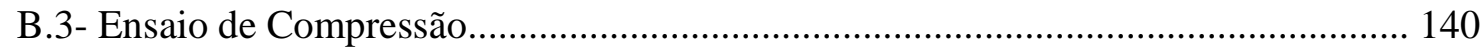

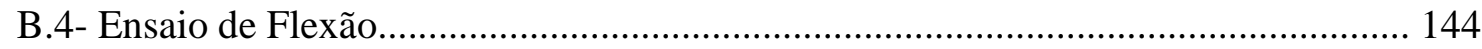

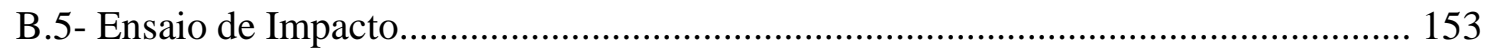




\section{RESUMO}

CANDIAN, L. M. (2007). Estudo do polietileno de alta densidade reciclado para uso em elementos estruturais. Dissertação de Mestrado - Escola de Engenharia de São Carlos, Universidade de São Paulo, São Carlos-SP, Brasil.

O alto consumo de energia para a produção de metais e de cimento, a pressão em relação à utilização de madeira tropical e a abundância de material plástico vêm contribuindo para o desenvolvimento de pesquisas e a aplicação dos termoplásticos na construção civil, em elementos estruturais que, em sua grande maioria, são constituídos de madeira, de aço e de concreto. O progresso dos materiais poliméricos pode ser comprovado pelos diversos produtos que estão sendo projetados, principalmente na Europa e nos Estados Unidos, como passarelas, dormentes, marinas, etc. Foi escolhido o polietileno de alta densidade (PEAD) reciclado, por ser um dos materiais poliméricos rígidos mais disponíveis para reciclagem. Nesse contexto, o objetivo deste trabalho foi a caracterização do PEAD reciclado. Foi determinada a composição do material polimérico (PEAD) reciclado obtido no mercado, por meio dos ensaios termoanalíticos: calorimetria exploratória diferencial e análise termogravimétrica. Os resultados mostraram que o material fornecido pela empresa de reciclagem é isento dos contaminantes comumente encontrados nos materiais reciclados e apresenta um grau de pureza bastante significativo. A determinação das propriedades mecânicas, por meio dos ensaios de tração, de compressão, de flexão e de impacto Izod, finaliza o estudo do material analisado. Nesses ensaios, a resistência obtida foi próxima dos valores encontrados na literatura, para o PEAD virgem, e pouco inferior à do concreto e à da madeira. Entretanto, a rigidez do PEAD reciclado foi bem menor que a dos materiais de construção tradicionais, sendo essa sua maior deficiência. Concluiu-se que o PEAD reciclado pode ser aplicado em elementos estruturais, desde que sejam estudadas possíveis formas de controlar sua deformabilidade, como a incorporação de nervuras, a utilização de blendas poliméricas e adição de cargas minerais e de fibras de elevado módulo de elasticidade e resistência.

Palavras-chave: polímeros reciclados, elementos estruturais, polietileno de alta densidade reciclado, ensaios termoanalíticos, ensaios mecânicos, resistência, rigidez. 


\section{ABSTRACT}

CANDIAN, L. M. (2007). Recycled high density polyethylene characterization for use in structural members. M.Sc. Dissertation - Sao Carlos School of Engineering, University of Sao Paulo, Sao Carlos-SP, Brazil.

The use of thermoplastics in civil engineering has been increasing considerably in the last decades. The latter is due to large amount of plastic material and high cost on a production of metals and cement for reinforced concrete, besides the lack of wood. This could be proved by the development of new thermoplastics products, especially in Europe and United States, like bridges, railway sleepers, posts, etc. Recycled high density polyethylene (HDPE) was chosen due to the fact that it is one of the most rigid recycled polymers available on the recycling industry. In this study, recycled polymer has been characterized in order to determinate the recycled material composition available in the market. The characterization of recycled HDPE samples was made by thermo gravimetric analysis and differential scanning calorimetry. Consequently, mechanical properties were determinated by tensile test, compression test, flexural test and impact Izod. The results of thermal analysis showed that the recycled material is exempt from possible contaminants and has a significant pureness degree. Under tension, compression, bending and impact conditions, the strength was around the pure polymer and little smaller of the concrete and wood. In contrast, the stiffness was much lower in comparison to traditional materials, their worst characteristic. These problems could be overcome through the study of polymeric blends, adding high modulus and strength fibers and charges and adding ribs. Then the recycled polymer could be applied as a structural element.

Keywords: recycled polymers, structural members, recycled high density polyethylene, thermal analysis tests, mechanical tests, strength, stiffness. 
Desde a Antigüidade, o homem retira produtos da natureza para utilização na construção civil, como barro, areia, pedra, madeira, entre outros. Devido à oferta insuficiente de recursos naturais, surge a necessidade de o homem modificar e criar novos materiais, para atender plenamente suas aspirações, dando origem aos produtos sintéticos, como o plástico, que, desde a sua descoberta, no início do século XX, vem sendo integrado a todos os estilos de vida, com o emprego variando de utensílios domésticos à ciência sofisticada e aos instrumentos médicos.

\section{1- CONSIDERAÇÕES INICIAIS}

Goma-laca, borracha, asfalto e celulose são exemplos de plásticos naturais. Porém, são os plásticos sintéticos que estão cada vez mais presentes na vida das pessoas.

A palavra plástico, que vem do grego plastikó, é um termo geral que significa capaz de ser moldado, sob uma ação exterior. Os materiais designados como plásticos não necessariamente têm essa propriedade, mas a exibiram em algum estágio de sua fabricação, quando foram moldados. Outros materiais, como o aço ou o vidro, apresentam essa característica e não são considerados materiais plásticos. Portanto, a definição adotada para os plásticos é que são materiais artificiais, constituídos por resinas sintéticas e que, em algum momento de sua fabricação, adquiriram condição plástica, durante a qual foram moldados, com a utilização de calor ou de solventes, pressão e moldes (Blass, 1985).

O plástico é um material sintético constituído de macromoléculas e pertence a uma grande família, conhecida por polímeros. Essas macromoléculas são cadeias formadas pela repetição de pequenas e simples unidades básicas, meros, ligadas covalentemente. O termo mero vem do grego e significa parte, unidade de repetição, e poli significa muitas. Daí a origem do termo polímero. 
Geralmente o monômero, que é MP de cada polímero sintético, é obtido a partir do petróleo ou do gás natural, pois essa é a forma mais barata, mas é também possível obter monômeros a partir da madeira, do álcool, do carvão e até do $\mathrm{CO}_{2}$, pois o carbono, o átomo principal que constitui os materiais poliméricos, está presente em todas essas matérias-primas.

\section{2- HISTÓRICO}

A introdução dos polímeros e dos compósitos poliméricos na construção civil foi um processo muito rápido, quando comparado com o dos materiais comumente usados na indústria da construção.

Os compósitos poliméricos têm sido utilizados predominantemente nas indústrias aeroespaciais e marinhas. Entretanto, nas últimas três décadas, houve uma conscientização entre os engenheiros civis e estruturais sobre a importância das propriedades mecânicas e de serviço que esses materiais apresentam, aumentando a confiança em relação a seu potencial, utilizandoos na renovação da infra-estrutura civil, mourões, pilares, passarelas, entre outras aplicações (Hollaway, 2003).

Antes da descoberta dos polímeros sintéticos, o homem utilizava macromoléculas orgânicas de origem natural, para fabricação de objetos no vestuário, na construção civil, como o asfalto utilizado em tempos pré-bíblicos, além de outras aplicações com o âmbar, que já era conhecido pelos gregos, e a goma, pelos romanos.

A descoberta do processo de vulcanização da borracha, a partir do látex, ocorreu em 1839 pela Goodyear, sendo considerada um grande marco na história da indústria dos polímeros. Porém, foi o celulóide, criado em 1860 por meio da modificação química de moléculas de celulose, que alavancou a indústria cinematográfica, sendo comercializado como fibras de rayon, celofane, entre outros. Entretanto, seu emprego caiu em desuso, por ser altamente inflamável e desbotar facilmente na luz.

O Parkesine, material duro com a característica de moldagem em diversas formas, foi o primeiro material semi-sintético, introduzido em 1862 por Alexander Parkes. O primeiro plástico real, inteiramente sintético, foi o fenol-formaldeído, a baquelite, introduzida em 1909 pelo belga Leo Hendrik Baekeland. Esse composto, por ser uma resina rígida pouco inflamável, foi 
amplamente empregado na fabricação de carcaças de equipamentos elétricos, até o surgimento de outros materiais, em meados dos anos 50, que permitiam maior variação de cor. Os materiais fenólicos são importantes plásticos de engenharia, até os dias atuais.

Estima-se que, no fim dos anos 20 e no início dos anos 30, foram fabricados em torno de 23.000 toneladas de plástico nos Estados Unidos, na sua grande maioria constituídos de materiais fenólicos e celulósicos. A década de 20 foi marcada pelo surgimento do acetato de celulose, o poli (cloreto de vinila) (PVC), o poli (metacrilato de metila) (PMMA), e a resina uréiaformaldeído.

Chapas de acrílico foram usadas em larga escala nas janelas de aviões, durante a II Guerra Mundial. Nessa mesma época, foram desenvolvidos vários produtos: resina transparente de poliéster (CR-39), filme de cloreto de vinila (Saran), polietileno (PE), resinas siliconadas, náilon (PA), acrílico (Perspex), politetrafluoroetileno (Teflon). O poliestireno (PS), o poliacetato de vinila (PVA), o polipropileno (PP) e muitos outros plásticos já haviam sido descobertos. Foram utilizadas as primeiras máquinas voltadas à produção industrial de peças plásticas, baseadas em injeção, sopro e vácuo.

Novos materiais continuavam a ser desenvolvidos, como ABS, acetal, polifluoreto de vinila, ionômeros e policarbonetos. Os processos, como moldagem por injeção, termoconformação, extrusão, moldagem por transferência e fundição, já estavam bem desenvolvidos, possibilitando à indústria substituir muitos materiais por plásticos, a um custo bastante inferior, nas mais diversas aplicações.

As aplicações estruturais do plástico na construção civil se iniciaram nos Estados Unidos e na Europa, com mais intensidade na Grã-Bretanha, com a escassez de materiais de construção devido ao grande consumo, durante a II Guerra Mundial. Porém, uns dos principais materiais de interesse tecnológico foram os compósitos poliméricos reforçados com fibras de vidro, que surgiram durante a década de 60 , com a produção de resinas, catalisadores e aceleradores.

Durante a década de 70 e início dos anos 80, foram erguidos notáveis edifícios no Reino Unido, como a escola Morpeth, em Londres, casa Mondial, ao lado norte de Tamisa, em 
Blackfriers, Londres, edifício Expresso Americano, em Brigghton, e o Covent Garden Flower Market, em Nine Elms, Londres, este ilustrado na figura 1.1.

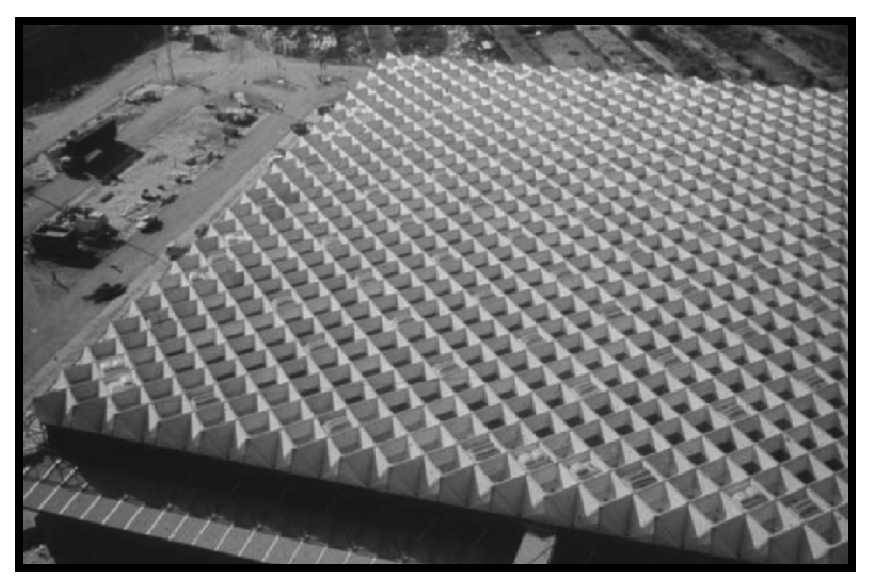

Figura 1.1: Covent Garden Flower Market, Reino Unido. Fonte: Hollaway (2003).

Essas obras foram construídas a partir de um sistema de esqueleto, utilizando vigas e pilares de concreto armado e/ou aço e GFRP (barra de fibra de vidro impregnada por polímero), usado como unidade de suporte de carregamentos, a fim de preencher os espaços entre vigas e pilares. As fibras de vidro nos componentes de GFRP eram dispostas aleatoriamente.

A figura 1.2 ilustra a evolução dos compósitos poliméricos na construção civil.

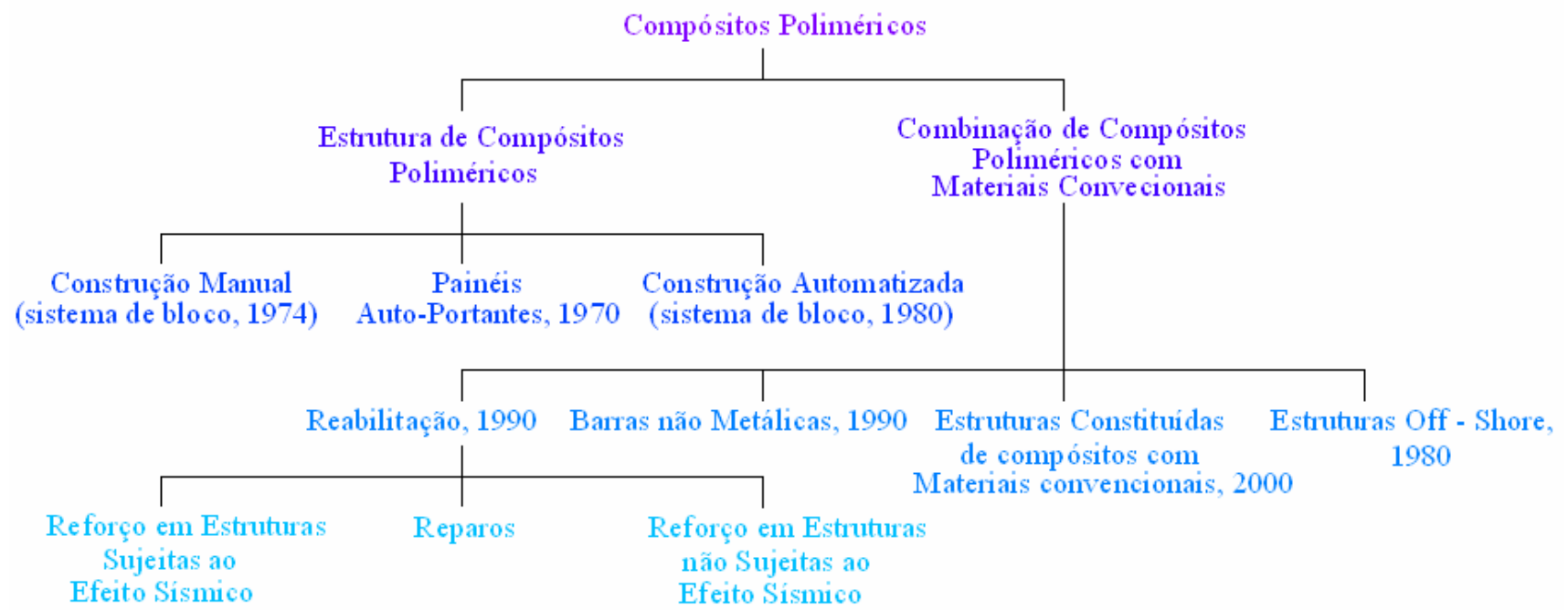

Figura 1.2: A utilização de compósito polimérico na construção civil. Fonte: Hollaway (2003). 
Nosker e Renfree (www.amipp.rutgers.edu/html/group_member_lynch.htm), pesquisadores da AMIPP, Centro de Materiais Avançados via Processamento de Polímeros Imiscíveis, da Universidade Rutgers em New Jersey (Estados Unidos), vêm desenvolvendo materiais estruturais a partir de blendas poliméricas, como PEAD/PS, descoberta em 1988, combinada com outros materiais como cerâmicas e metais. O campo de aplicação desses compósitos varia de vigas de seção I, ilustrada na figura 1.3, pilares de plástico, figura 1.4, a dormentes para ferrovias, que estão sendo fabricados por diversas empresas, como Tietek, U.S. Plastic Lumber, Polywood, Cogumelo, figura 1.5.

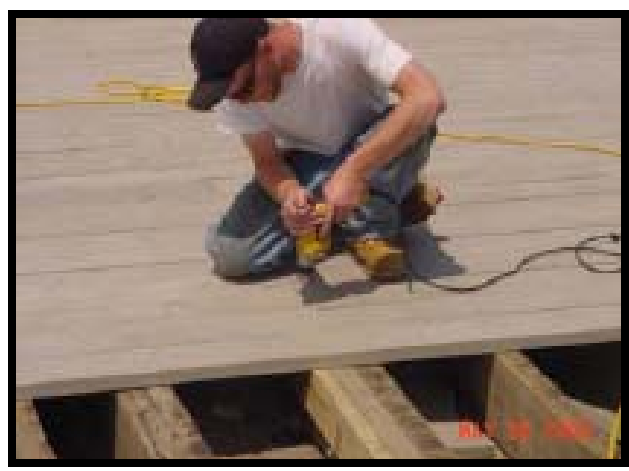

(a)

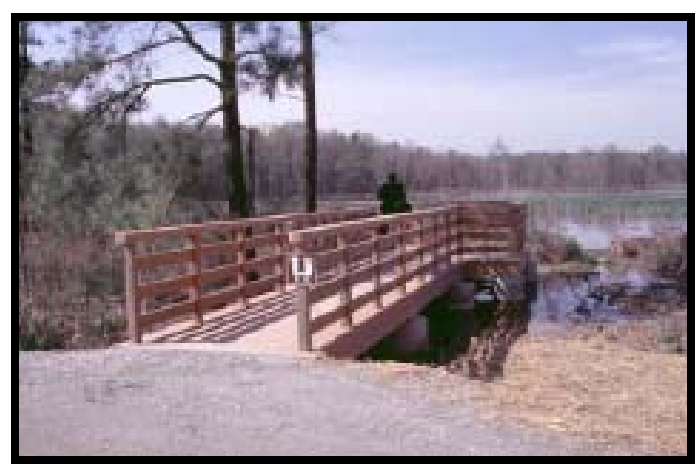

(b)

Figura 1.3: Vigas de seção I para passarelas, desenvolvido na AMIPP.

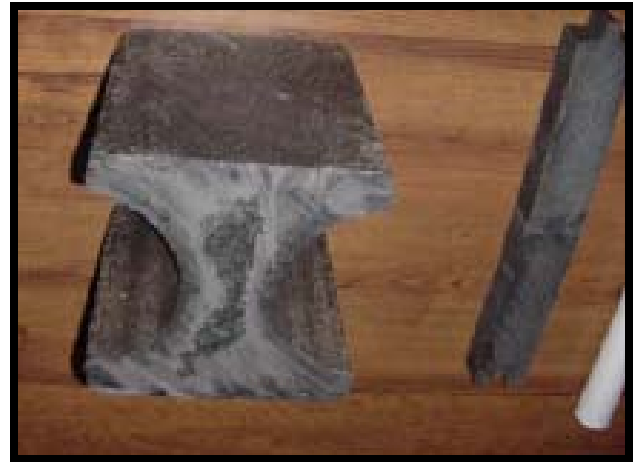

(a)

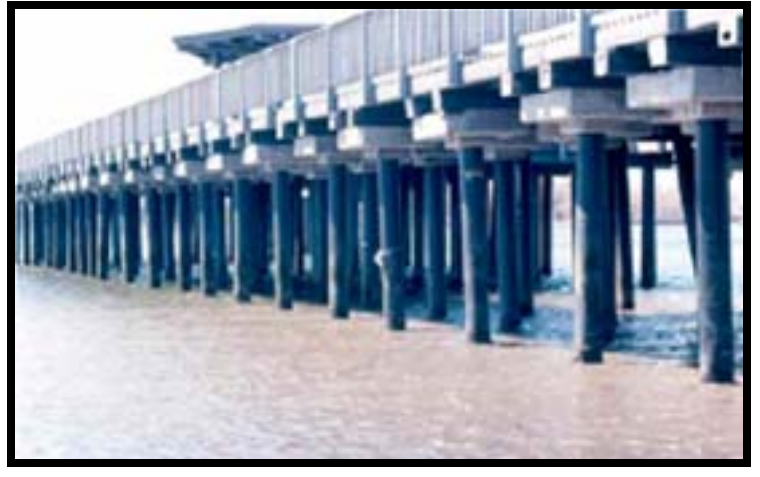

(b)

Figura 1.4: Marina construída com pilares de plástico reciclado desenvolvido na AMIPP. 


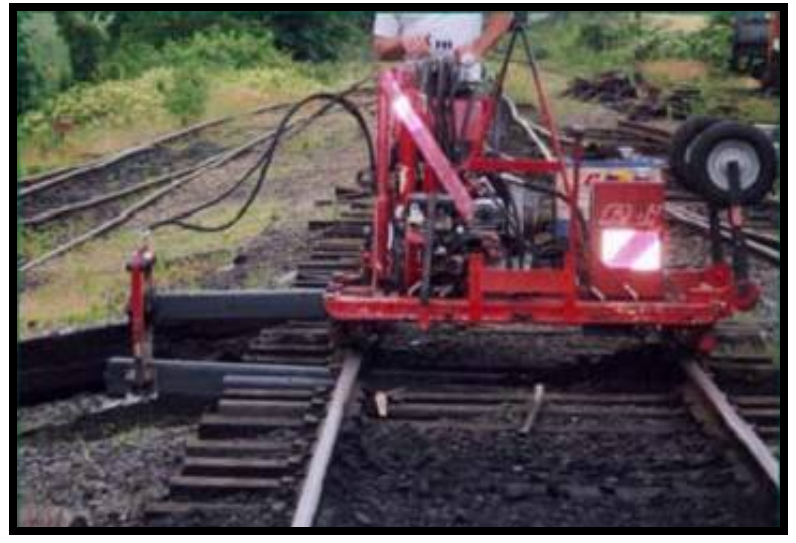

(a)

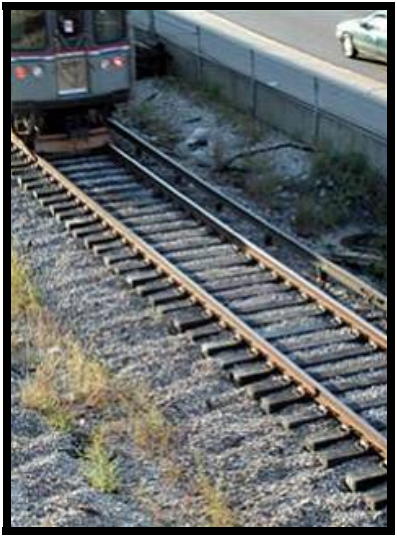

(b)

Figura 1.5: Dormentes de plástico reciclado produzidos pela Polywwod Plastic Lumber de New Jersey. Fonte: Schut (2004).

Sullivan et al. (1999) desenvolveram um componente polimérico emborrachado, a partir de plástico reciclado, e um componente de preenchimento contendo mica, que por sua vez, podem ser aplicados em dormentes, meio-fio de estacionamentos e estacas em marinas. Outra vantagem desses materiais é a combinação de resistência mecânica e baixo peso, além do fácil processamento, por moldagem e por extrusão.

\section{3- OBJETIVOS}

O objetivo principal deste trabalho é determinar as propriedades mecânicas de resistência e rigidez de um material polimérico reciclado, constituído basicamente de polietileno de alta densidade, por ser um dos materiais poliméricos rígidos mais procurados para reciclagem.

Os objetivos específicos são:

- Caracterizar o material reciclado (PEAD) por meio de ensaios termoanalíticos, como DSC (calorimetria exploratória diferencial) e TG (análise termogravimétrica);

- Avaliar experimentalmente as propriedades mecânicas (resistência e módulo de elasticidade) do material em questão, por meio dos ensaios de tração, de compressão, de flexão e de impacto Izod; 
- Indicar a viabilidade da utilização do material na produção de elementos estruturais para construção civil.

\section{4- JUSTIFICATIVA}

Atualmente, projetistas e engenheiros trabalham com os plásticos porque eles oferecem combinações de vantagens não encontradas em outros materiais, como baixo peso específico, resiliência, resistência à deterioração por decomposição e ataque de microorganismos, resistência à corrosão, resistência mecânica, transparência, facilidade de processamento e baixo custo de manutenção. Além disso, algumas de suas propriedades podem ser melhoradas com a utilização de blendas poliméricas e adição de cargas minerais e fibras de elevado módulo de elasticidade e resistência.

O alto consumo de energia na produção de metais e cimento, a pressão contra a utilização da madeira tropical e o baixo custo do plástico reciclado estimularam sua inserção na construção civil, em estruturas que antigamente eram constituídas apenas de madeira, aço ou concreto.

A tabela 1.1 mostra que o consumo energético para fabricação dos materiais usualmente utilizados na construção civil é muito superior ao dos plásticos, segundo Ferraroli et al. (2001), fator de extrema importância no que tange à racionalização de energia elétrica. Essa análise considera todo o ciclo de vida do material, da extração da matéria-prima à obtenção do produto final.

Tabela 1.1: Consumo energético de alguns materiais. Fonte: Ferraroli et al. (2001).

\begin{tabular}{ccc}
\hline Material & $\begin{array}{c}\text { Massa Específica } \\
\left(\mathbf{K g} / \mathbf{m}^{3}\right)\end{array}$ & $\begin{array}{c}\text { Consumo de } \\
\text { Energia Elétrica } \\
\left(\mathbf{M W h} / \mathbf{m}^{3}\right)\end{array}$ \\
\hline PVC & 1200 & 4,2 \\
\hline PEAD & 1050 & 1,41 \\
\hline PS & 1050 & 1,02 \\
\hline PET & 1330 & 2,93 \\
\hline Vidro & 2600 & 2,08 \\
\hline Alumínio & 2700 & 92 \\
\hline
\end{tabular}

A caracterização dos materiais poliméricos se dá com relação à sua estrutura, composição, avaliação e durabilidade. É de fundamental importância situar o material reciclado disponível no 
mercado a fim de compará-lo com os materiais puros. Porém, neste trabalho, não será realizada uma análise do ciclo de vida do plástico reciclado. Serão analisadas propriedades mecânicas, como módulo de elasticidade e resistência.

A reciclagem de materiais é uma atividade de extrema importância em termos ambientais, sociais e econômicos, pois contribui para a geração de emprego e de renda e a preservação de fontes esgotáveis de matéria-prima, além de reduzir gastos com a disposição final dos resíduos e com limpeza e saúde pública. Ao mesmo tempo, a reciclagem contribui para o reaproveitamento das perdas de produção nas indústrias.

Os plásticos mais utilizados para reciclagem são constituídos basicamente por termoplásticos, que por sua vez são os empregados na Engenharia. A figura 1.6 representa a demanda de resinas termoplásticas, no ano de 2002.

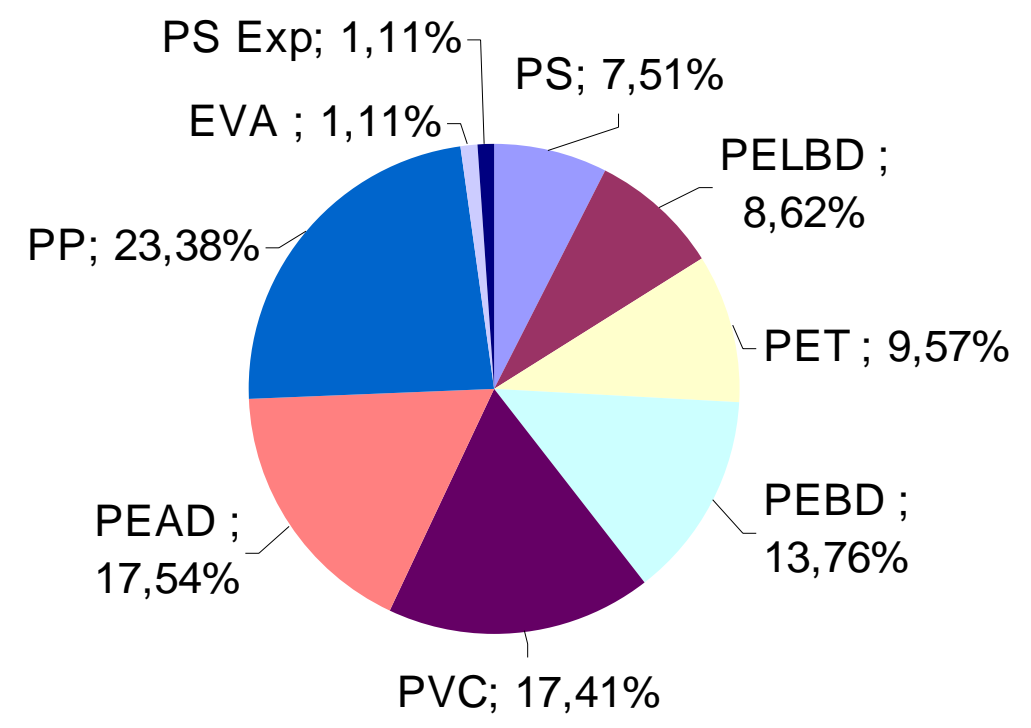

Figura 1.6: Termoplásticos de maior utilização. Fonte: Agnelli (2005).

Segundo Spinacé et al. (2005), dentre os termoplásticos, o PEAD e o PP apresentaram um aumento significativo de volume e de taxa de crescimento, quando comparado com o aumento do PEBD e do PS, e em relação ao PVC, que apresentou uma diminuição nesses valores, no período de 1982 a 2002. O PE e o PP são os termoplásticos mais procurados pelas empresas que atuam nesse setor, elas reciclam de 20 a 50 t/mês, em média. 
Este trabalho, juntamente com as dissertações de mestrado "Elementos Estruturais de Plástico Reciclado", de Ricardo Alves Parente, e "Cruzetas de Polímeros Reciclados: Caracterização dos Materiais, Análise Numérica e Ensaios de Modelos Reduzidos”, de Gláucia Maria Dalfré, fazem parte de uma linha de pesquisa sobre Elementos Estruturais de Polímeros Reciclados, recente no Departamento de Engenharia de Estruturas, SET/EESC/USP, que evolve outros departamentos e unidades, como o Departamento de Engenharia Mecânica SEM/EESC/USP e a empresa IPEX, de São Carlos.

\section{5- ESTRUTURA DA DISSERTAÇÃO}

Este trabalho consiste em um estudo experimental, compreendendo esta Introdução e um total de sete capítulos. As demais etapas realizadas estão indicadas a seguir:

Capítulo 2: conceitos e definições sobre a reciclagem dos plásticos, bem como a importância da reciclagem para o desenvolvimento de um país, e os plásticos mais reciclados;

Capítulo 3: apresentação dos plásticos existentes, por meio de sua classificação em relação à estrutura química, às características tecnológicas, ao comportamento mecânico, etc., além de uma pequena abordagem com relação às transições térmicas, às propriedades mecânicas e ao polietileno de alta densidade;

Capítulo 4: aspectos importantes da utilização dos compósitos poliméricos, bem como sua classificação;

Capítulo 5: descrição do material utilizado, do processamento e da usinagem, para obtenção dos corpos-de-prova, além da instrumentação empregada e dos métodos para realização dos ensaios de caracterização e dos ensaios mecânicos;

Capítulo 6: análise e discussão dos resultados obtidos no programa experimental;

Capítulo 7: conclusões obtidas ao longo do trabalho. 


\section{RECICLAGEM DOS PLÁSTICOS}

Hoje em dia, plásticos e borrachas são essenciais no cotidiano do ser humano, sendo possível medir o progresso de um país por meio da produção desses materiais. Embora o consumo per capita do plástico no Brasil seja muito baixo, quando comparado com o de outros países, cerca de 21,78 kg/hab/ano em 2006 (www.jorplast.com.br/jpfev07/pag00.htm), ele tem aumentado significativamente nos últimos anos, gerando desenvolvimento da indústria de produção e de transformação, além de produtos de melhor qualidade.

O conceito de qualidade total em relação aos resíduos gerados está diretamente ligado à minimização dos impactos ambientais de todo o sistema de manejo dos resíduos. Porém, no início, a reciclagem tinha o objetivo de reaproveitamento das perdas de produção das indústrias, já que é possível economizar em torno de $50 \%$ de energia.

\section{1- IMPORTÂNCIA DA RECICLAGEM}

A cada dia que passa a reciclagem de materiais torna-se uma das atividades mais importantes de proteção ambiental, atribuindo valores econômicos e desenvolvimento tecnológico. Isso ocorre devido ao aumento da produção e do consumo de produtos industrializados.

Esse fato pode ser comprovado por meio da quantidade de artigos plásticos consumidos e descartados pela população. Em 2002, segundo Gorni (2006), do total de 3,97 milhões de toneladas $(3,97 \mathrm{Mt})$ de plásticos consumidos no Brasil, 1,58Mt foi usada na forma de embalagens e 0,46Mt como outros tipos de produtos descartáveis, ou seja, mais de dois milhões de toneladas de plásticos foram lançados nos lixões, que correspondem a $51,3 \%$ do plástico consumido no país. Nos países desenvolvidos, como o Japão, a situação é mais crítica. De 11 milhões de toneladas de resinas plásticas consumidas em 2001, 86,4\% foram descartadas. 
Assim como nos países desenvolvidos, o mercado de reciclagem das embalagens plásticas pode trazer, para o Brasil, reflexos sócio-econômicos relacionados diretamente com a melhoria da qualidade de vida da população. De acordo com Spinacé et al. (2005), cerca de US\$ 160 bilhões/ano é movimentado no setor da reciclagem, além de empregar 1,5 milhões de pessoas.

A necessidade de crescimento econômico do Brasil deve basear-se no conceito de desenvolvimento sustentável, que segundo a abordagem de Tamemmagi ${ }^{*}$, (1999 apud Hamada, 2003), este princípio está diretamente ligado com a proteção da saúde e do meio ambiente, a minimização do sacrifício das futuras gerações e a conservação de recursos, como ilustrado na figura 2.1 .

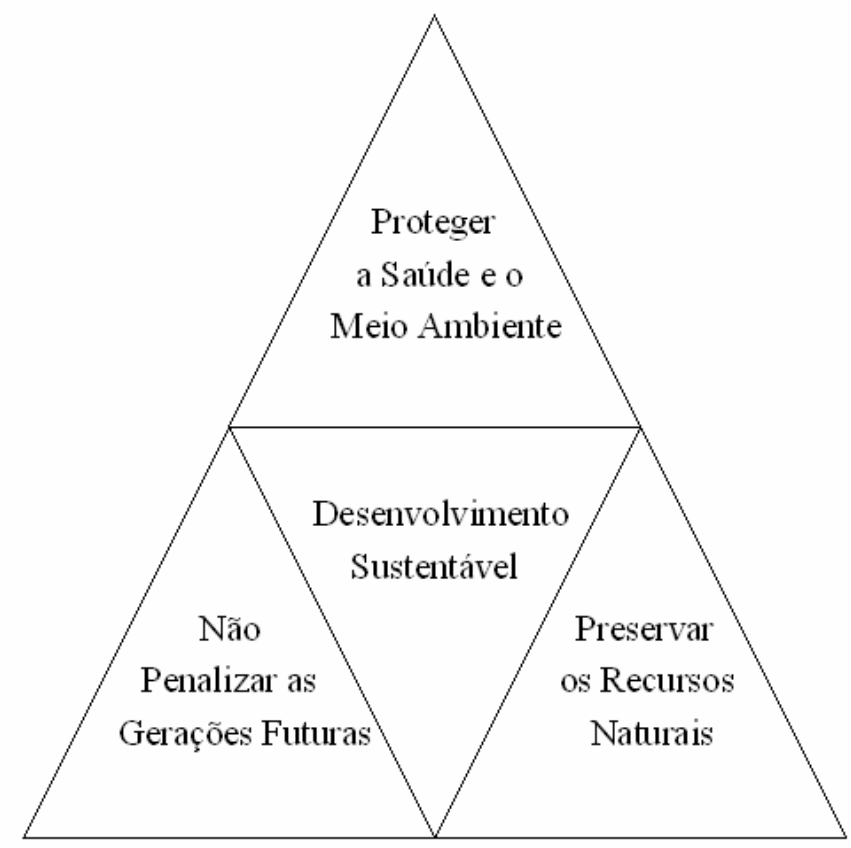

Figura 2.1: Princípios do desenvolvimento sustentável e o manejo de resíduos. Fonte: Hamada (2003).

A produção e a disposição de resíduos no solo, em lixões ou aterros sanitários nas quantidades atuais, demonstram que há bastante desperdício, além da concentração de

\footnotetext{
*Tammemagi, H. The Waste Crisis: Landfills, Incinerators, and the Search for a Sustainable Future. Oxford University Press, Inc. New York, ISBN 0-19-512898-2. 279 p. 1999.
} 
determinados materiais úteis ser maior nos depósitos de lixo que na forma de minério, segundo White et al ${ }^{*}$, (1993 apud Hamada, 2003).

Dos materiais ao alcance da população, pode-se dizer que os plásticos são os mais eficientes e versáteis. Além disso, eles oferecerem uma grande contribuição no desenvolvimento da sustentabilidade, devido aos aspectos sociais, ambientais e econômicos relacionados à reciclagem dos polímeros.

Embora as embalagens plásticas correspondam a apenas $7 \%$ do lixo sólido, (www.planetaplastico.com.br/lite_ambiente.htm), os plásticos têm sido um dos principais vilões entre os materiais presentes nos aterros sanitários, por ter vida útil longa, difícil processo de separação (pela grande diversidade de plásticos), resistência à degradação, leveza, flutuando em lagos e em cursos de água, densidade baixa, gerando grandes volumes, entre outros fatores.

No ano de 2000, a indústria de transformação de materiais plásticos produziu 133,5 milhões de toneladas: $46,5 \%$ dessa produção aconteceu nos países do Nafta, os países da União Européia responderam por $38,7 \%$ da produção, o Japão por $14,7 \%$ e o Brasil foi responsável apenas por 2,8\% do total, que corresponde a 3,8 milhões de toneladas de plástico, (http://www.desenvolvimento.gov.br/arquivo/sdp/proAcao/forCompetitividade/impZonLivCome rcio/23transformadosPlasticosResumo.pdf).

Segundo Agnelli (2005), em 2002 foram reciclados cerca de 13 mil toneladas de plásticos por mês, em toda a grande São Paulo. As resinas termoplásticas foram destinadas para: embalagens (39,73\%), construção civil (13,67\%), descartáveis (11,55\%), componentes técnicos $(8,04 \%)$, agrícolas $(7,67 \%)$, utilidades domésticas $(4,72 \%)$, outros $(14,62 \%)$, conforme ilustrado na figura 2.2 .

\footnotetext{
* White, P.R., Franke, M., Hindle, P., Integrated Solid Waste Management: A Lifecycle Inventory. Blackie Academics \& Professional (imprint of Chapman \& Hall). ISBN 0-7514-0046-7. 362 p. 1993.
} 


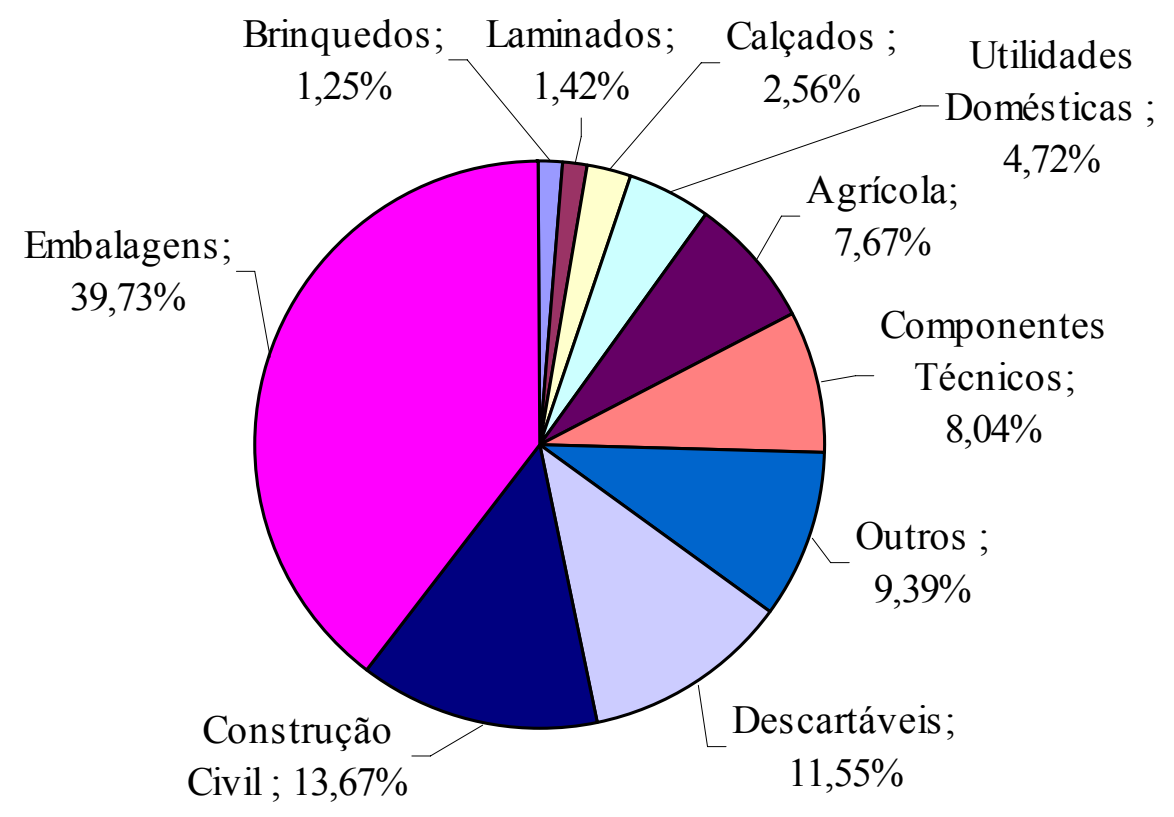

Figura 2.2: Segmentação do mercado de termoplásticos no ano de 2002. Fonte: Agnelli (2005).

Pode-se perceber que a indústria da construção é a segunda maior consumidora de plásticos do mercado mundial. Porém, seu uso é mais freqüente em componentes não estruturais, para revestimento, iluminação, isolamento térmico e acústico, impermeabilização, adesivos e acessórios.

\section{2- CONCEITOS}

A reciclagem consiste do reprocessamento de um material, de modo a fazê-lo voltar como matéria-prima para a fabricação de novos produtos. A reciclagem dos plásticos é de vital importância para o ciclo de transformação dos resíduos sólidos. Para viabilizar este processo, é necessário identificar e separar os diversos tipos de polímeros.

Existem resinas de fácil identificação, porém, na maioria das vezes, é necessário realizar alguns testes, devido à presença de aditivos, de cargas e de pigmentos que dificultam a separação. Existe o teste de odor dos vapores de queima, de aparência da chama, de temperatura de fusão e de solubilidade, que são baseados nas características físicas e de degradação térmica, além da separação por diferença de densidade, conhecida por separação automatizada. No Brasil, o código 
de identificação é dado pela NBR 13.230 - Reciclabilidade e identificação de materiais plásticos, da Associação Brasileira de normas Técnicas - ABNT (1994).

Os plásticos oriundos de coleta seletiva, por serem mais limpos que aqueles separados nos lixões e nas usinas, têm maior preço de venda. Eles não precisam passar por processos de lavagem, antes de serem encaminhados para reciclagem. Segundo Agnelli (2007), ocorre o contrário com os plásticos de coloração preta, que, devido a sua não uniformidade, por serem constituídos de uma mistura de diversos polímeros, eles têm menor preço de venda, quando comparados aos demais (informação verbal) ${ }^{*}$. Dentre os principais contaminantes do plástico rígido estão presentes: gorduras, restos orgânicos, alças metálicas, etiquetas e grampos.

A etapa da separação, denominada triagem, ilustrada na figura 2.3 , é a inicial e a mais importante para reciclagem, pois a presença de contaminantes, mesmo em concentrações pequenas, pode alterar as propriedades do polímero. Após a separação, o material pode ser embalado e estocado.

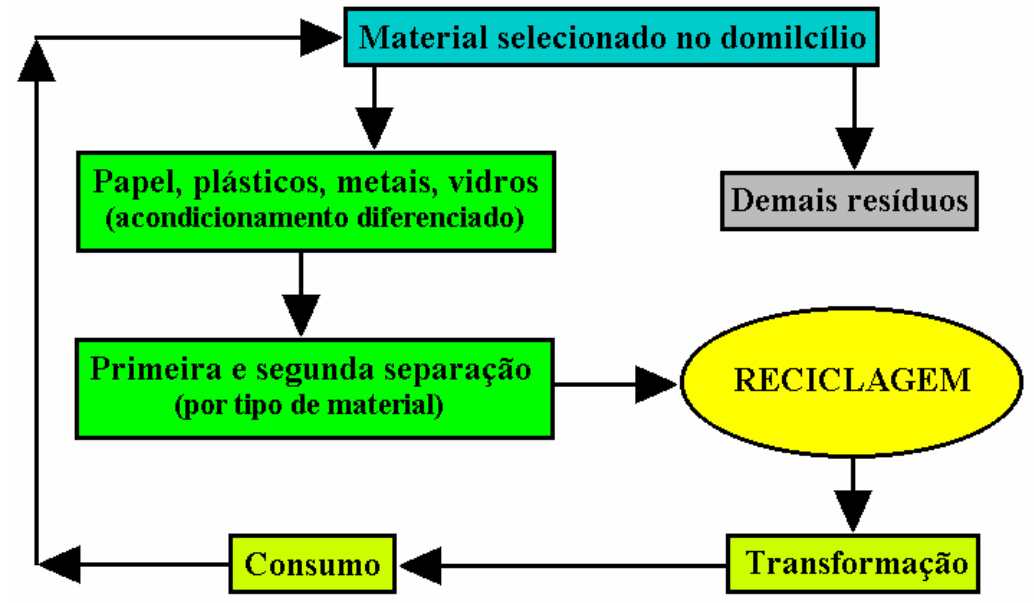

Figura 2.3: Etapa da separação. Fonte: www.institutodopvc.org/reciclagem.htm.

Para dar seqüência ao processo de reciclagem, o material é moído, utilizando um moinho de facas rotativas, e lavado, para ser encaminhado ao processamento industrial (ver figura 2.4).

\footnotetext{
* Informação fornecida pelo prof. José Augusto M. Agnelli, do DEMa/UFSCar, em 2007.
} 


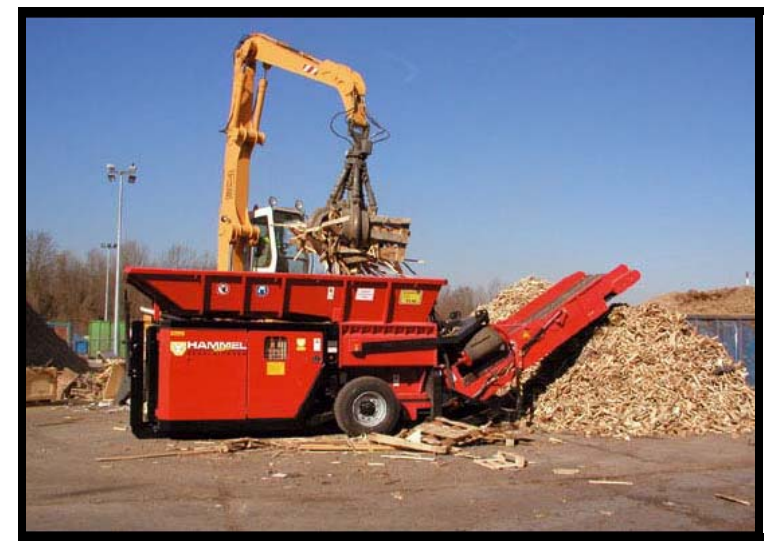

Figura 2.4: Moagem do material de maior dimensão. Fonte: www1.sac.ac.uk/info /External/Publications/WasteRecycling/Chapter7-SettingupaPlasticsRecyclingBusiness.pdf .

Quando seco, no caso de plásticos flexíveis, por meio de processo mecânico ou térmico, eles são transferidos para o aglutinador, transformando-se numa pasta, devido ao aquecimento do material por fricção, decorrente da ação das hélices, que giram em alta rotação. Adiciona-se, então, à pasta plástica, água em pequena quantidade, para provocar o resfriamento brusco e aumentar a densidade do material pela contração das moléculas dos polímeros, que faz o plástico adquirir a forma de grânulos (flakes) (ver figura 2.5).

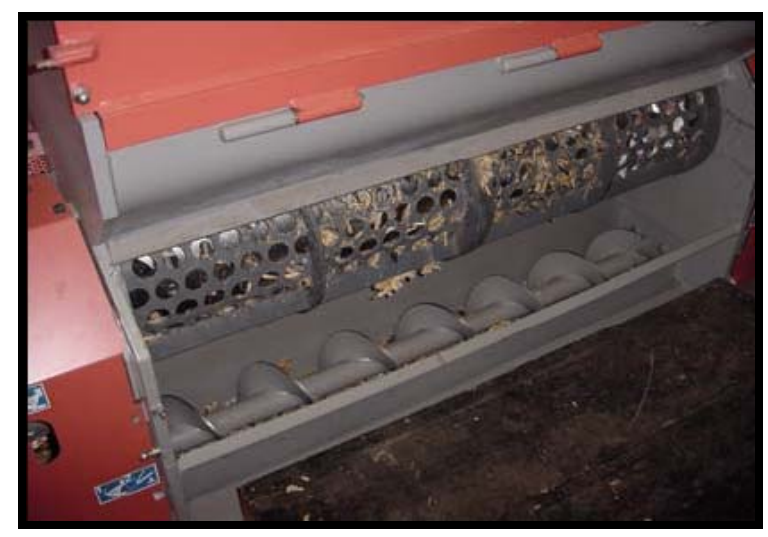

Figura 2.5: Processo de aglutinação. Fonte: www1.sac.ac.uk/info

/External/Publications/WasteRecycling/Chapter7-SettingupaPlasticsRecyclingBusiness.pdf .

Esses grânulos são colocados na extrusora, que os funde os transforma em tiras de material homogêneo. Essas tiras, em formato de espaguete, são banhadas para resfriarem e 
solidificarem, podendo ser picadas em grãos, denominados péletes, que consiste em matériaprima para fabricação de novos produtos (figura 2.6).

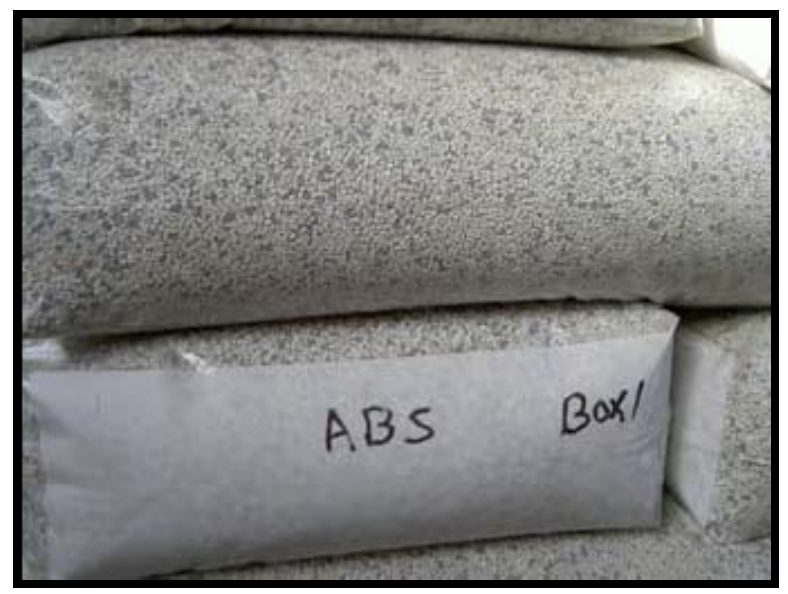

Figura 2.6: Péletes de ABS obtidos por meio do processo de extrusão. Fonte: www1.sac.ac.uk/info /External/Publications/WasteRecycling/Chapter7-SettingupaPlasticsRecyclingBusiness.pdf.

A produção de plástico de melhor qualidade e maior durabilidade gera uma degradação mais difícil e lenta e promove um aumento da reutilização de embalagens usadas, reduzindo o descarte em aterros.

\section{3- TIPOS DE RECICLAGEM}

Os polímeros reciclados podem ser obtidos por meio de quatro categorias distintas: primária, secundária, terciária e quaternária. As definições dessas categorias podem ser obtidas na ASTM D 5033-00 - Standard Guide for Development of ASTM Standards Relating to Recycling and Use of Recycled Plastics. Essas categorias são agrupadas em três técnicas: mecânica, química e energética.

\subsection{1- Reciclagem Mecânica}

Tanto a reciclagem primária quanto a secundária são conhecidas como reciclagem mecânica ou física, que consiste na transformação física de resíduos poliméricos em grânulos. A diferença entre elas é que a primária utiliza resíduos industriais e a secundária, resíduos pósconsumo e sobra de polímero industrial. 
As etapas da reciclagem mecânica são: separação do resíduo polimérico, moagem, lavagem, secagem, reprocessamento e transformação do grânulo em produto final, como ilustrado na figura 2.7 .

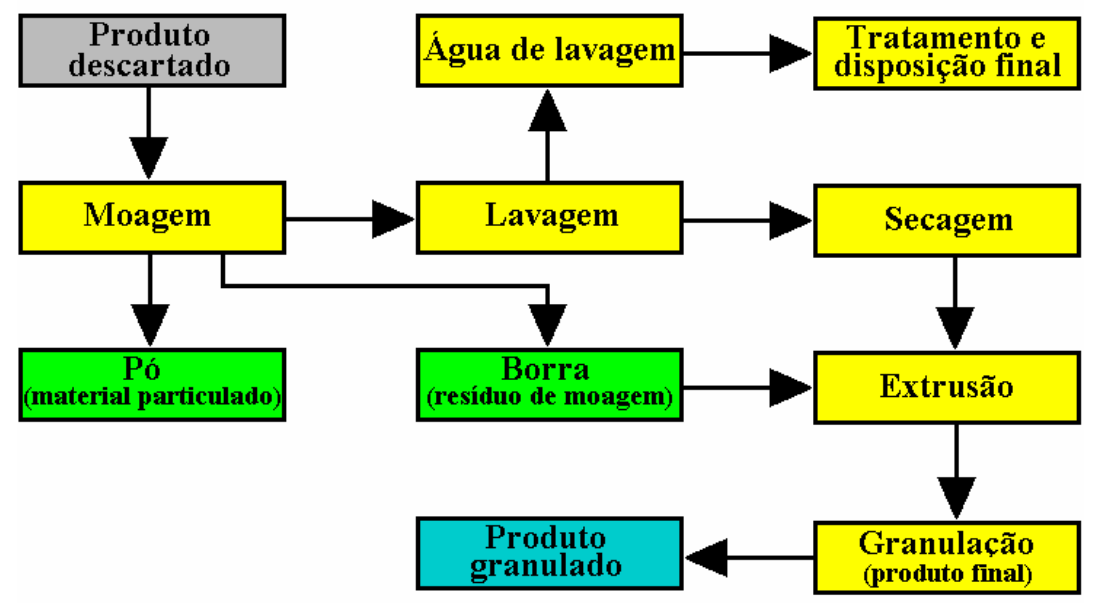

Figura 2.7: Reciclagem mecânica do PVC. Fonte: www.institutodopvc.org/reciclagem.htm.

Porém, é necessário realizar a coleta, a separação por tipo de plástico e a retirada de rótulos, de grampos e de outras impurezas, antes de realizar a reciclagem propriamente dita. A viabilização da reciclagem mecânica pode ser feita por meio de reprocessamento por extrusão, injeção, termoformagem, moldagem por compressão, entre outros processos. Quando o reprocessamento é feito por extrusão, ele é composto por aglutinação (no caso de plásticos flexíveis), extrusão propriamente dita e granulação.

A reciclagem primária consiste em transformar os resíduos poliméricos industriais em um único tipo de resina. Este tipo de reciclagem é o mais realizado no Brasil, sendo responsável por absorver 5\% do plástico consumido no país (www.cempre.org.br/fichas_ tecnicas_plastico_filme.php).

A reciclagem secundária é um mercado que vem crescendo, devido ao desenvolvimento de novas tecnologias para a mistura simultânea de diferentes resinas, sem que haja incompatibilidade entre elas e perda de resistência e de qualidade. Este tipo de reciclagem consiste basicamente na transformação dos resíduos poliméricos, oriundos dos resíduos sólidos, em polímeros, que podem ser misturados ou não. 
Um exemplo típico de reciclagem secundária é a madeira plástica, desenvolvida por duas tecnologias, uma japonesa e outra Belga (Syntal), de acordo com Spinacé et al. (2005). Ela é constituída da mistura de vários plásticos reciclados, podendo obter vigas, mourões de cerca e cruzetas para sustentação de fios elétricos, além de bancos de praça, postes de sinalização de ruas e estradas, instalações para marinas e locais onde a corrosão seja elevada, já que esses objetos podem ficar expostos a intempéries, sem sofrerem degradação rápida.

Devido às vantagens da reciclagem mecânica, como processo simplificado, acessibilidade a pequenas e médias empresas, pequeno investimento para instalação de uma planta de reciclagem, grande volume de polímero pós-consumo, custo reduzido de mão-de-obra e por depender do incentivo ao programa de coleta seletiva do lixo urbano, ela é a forma de reciclagem mais utilizada no Brasil. Além disso, ela contribui para a diminuição ou retirada da população que trabalha nos aterros sanitários. No restante do mundo, utilizam-se reciclagens química e energética, com maior freqüência.

\subsection{2- Reciclagem Química}

A reciclagem terciária consiste na utilização de processos químicos, como a pirólise, utilizada nas poliolefinas, para recuperar as resinas provenientes de resíduos poliméricos. Este processo consiste na despolimerização por aquecimento, transformando o plástico em óleo e gases, que serão reutilizados como matéria-prima na indústria petroquímica. Nylon 6, poli (etileno teraftalato) e acrílicos são exemplos de materiais onde se utilizam este tipo de reciclagem.

Esta reciclagem, também conhecida como reciclagem química, ainda não foi introduzida no Brasil, devido ao custo elevado, embora permita a utilização de misturas de diferentes tipos de plásticos.

Segundo Gorni (2006), apenas uma pequena fração dos rejeitos do material plástico reciclado na Alemanha, em 1996, apresentava pureza suficiente para ser reaproveitada pela recuperação exclusiva como matéria-prima. Cerca de $61 \%$ do plástico coletado para reciclagem era constituído por uma mistura de resinas que não permitia um reaproveitamento nobre, pois sua pureza girava em torno de apenas $88,6 \%$. Por meio da geração de energia e de calor, a reciclagem 
é possível com o processamento em alto-forno, por termólise, hidrogenação e gaseificação em leito fixo ou fluidizado. No restante, pode-se utilizar a reciclagem energética por incineração, já que são impuros para reciclagem química.

\subsection{3- Reciclagem Energética}

A reciclagem quaternária é baseada na recuperação de energia térmica nos resíduos poliméricos, por isso também pode ser chamada de energética. Isso é possível, pois os plásticos presentes no cotidiano do ser humano são excelentes combustíveis e possuem elevado poder calorífico, liberando grande quantidade de calor, quando submetidos a elevadas temperaturas.

Devido ao custo elevado das instalações, dos sistemas de controle de emissões e dos sistemas operacionais, além da exigência de mão-de-obra qualificada necessária para este tipo de reciclagem, ela não foi implantada no Brasil. Porém, os países que adotam este tipo de modalidade, como Áustria e Suécia, conseguem reduzir o volume de seus resíduos em até 90\%.

\section{4- POLÍMEROS RECICLADOS}

A cada dia que passa, o consumo de termoplásticos para produção de embalagens no Brasil aumenta cada vez mais, e isso repercute no aumento da reciclagem de polímeros. Segundo Spinacé et al. (2005), em 1996, a reciclagem de polímeros no Brasil girava em torno de $15 \%$ ao ano, já em 2000 esse número subiu para 17,5\%.

Os plásticos podem ser classificados em flexíveis e rígidos. Dentre os diversos tipos de termoplásticos rígidos, apenas cinco, listados a seguir, representam $90 \%$ do consumo nacional:

- $\quad$ Polietileno Tereftalato (PET), $\hat{1}$, utilizado em fibras sintéticas, em frascos de refrigerantes, de produtos de limpeza e de produtos farmacêuticos, etc.

- $\quad$ Polietileno de Alta Densidade (PEAD), $\stackrel{2}{2}$, empregado na confecção de engradados para bebidas, garrafas de álcool e de produtos químicos, baldes, tambores, tubulações para líquidos e gás, tanques de combustível, embalagens de leites, de sucos, de óleos lubrificantes, de agrotóxicos, etc. 
- $\quad$ Policloreto de Vinila (PVC), $\stackrel{3}{-}$, usado em frascos de água mineral sem gás, em tubos e conexões para água, em calçados, em encapamentos de cabos elétricos, equipamentos médico-cirúrgicos, lonas, esquadrias, revestimentos, etc.

- $\quad$ Polipropileno (PP), $\widehat{5}$, empregado em embalagem de massas alimentícias e biscoitos, potes de margarina, seringas descartáveis, equipamentos médico-cirúrgicos, fibras e fios têxteis, utilidades domésticas, autopeças, etc.

- $\quad$ Poliestireno (PS),,$\hat{-6}$, utilizado em copos descartáveis, placas isolantes, aparelhos de som e de TV, embalagens alimentícias, revestimento de geladeiras, material escolar, etc.

Essa numeração representa a classificação dos plásticos recicláveis adotada pela NBR 13230 (1994), a fim de facilitar a identificação dos plásticos no processo de triagem. A numeração de 1 a 7 da ABNT é concluída com o polietileno de baixa densidade (PEBD), representado pelo código $\left\{\begin{array}{l}4 \\ \text {, e os demais plásticos representados pelo código }\{7\end{array}\right.$

Elementos estruturais constituídos de materiais termoplásticos estão cada vez mais sendo utilizados nos países desenvolvidos, como Estados Unidos, Canadá, Japão, além de diversos países europeus. No Brasil, existem algumas empresas desenvolvendo elementos de material termoplástico, porém este é um campo de pesquisa recente.

A figura 2.8 ilustra uma ponte construída sobre o rio Mullica, New Jersey, com vão de $14 \mathrm{~m}$, largura de $3,5 \mathrm{~m}$ e um consumo de $14000 \mathrm{~kg}$ de polietileno de alta densidade e poliestireno. Essa obra foi concluída em outubro de 2002, pelos pesquisadores da AMIPP, sendo constituída inteiramente de plástico - guarda-corpos, vigas de sustentação e plataforma -, com exceção dos pilares de madeira, que foram aproveitados da estrutura anterior. No vão principal, foram utilizadas em torno de 250.000 garrafas plásticas (PEAD) e mais de 750.000 copinhos de café (PS). 


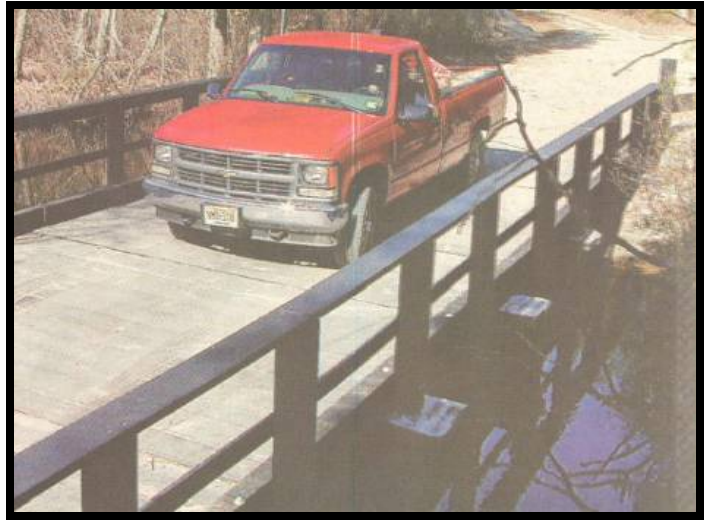

(a)

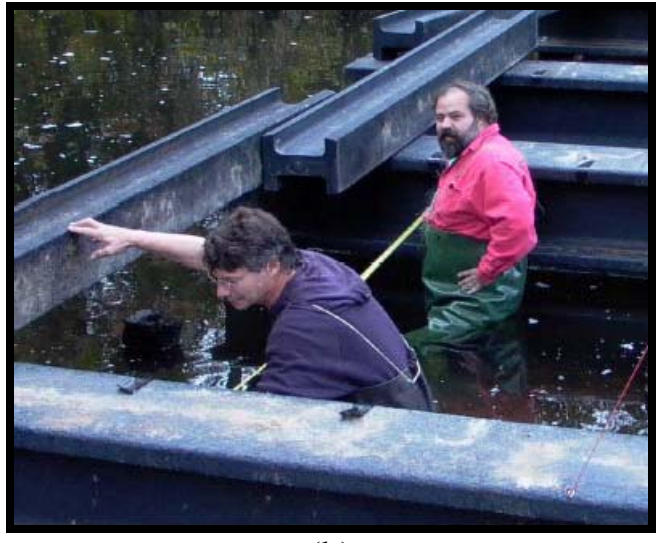

(b)

Figura 2.8: Ponte sobre o rio Mullica construída inteiramente de plástico. Fonte: Guterman (2003).

\section{5- CONSIDERAÇÕES FINAIS}

A utilização dos polímeros na construção civil existe há bastante tempo, porém é mais usual em elementos não estruturais, como, por exemplo, nas tubulações de água e de esgoto, telhas plásticas, calhas, esquadrias, etc. Os setores alimentícios, eletrodomésticos, automobilístico, entre outros, possuem maior utilização e divulgação dos produtos poliméricos. Por esse motivo que, embora a indústria da construção seja a segunda maior consumidora de plásticos do mercado mundial, pela sociedade, ela ainda não é reconhecida como tal.

O PEAD vem se tornando um dos plásticos mais reciclados, dentre os termoplásticos rígidos, devido às suas propriedades mecânicas e à significativa disponibilidade nos resíduos sólidos urbanos, cerca de 30\% do total de resíduos plásticos rígidos, Cruz e Zanin ${ }^{*}$ (1999, apud Caraschi, 2002). Por esse motivo que os pesquisadores da AMIPP vêm desenvolvendo elementos estruturais para construção civil de PEAD reciclado. Essa cultura está começando a existir no Brasil, porém ainda é incipiente. Por isso, faz-se necessário um maior estudo desse tipo de material.

\footnotetext{
"CRUZ, S.A.; ZANIN, M. Caracterização elétrica do HDPE reciclado proveniente de resíduo sólido urbano. In: CONGRESSO BRASILEIRO DE POLÍMEROS, 5., 1999, Águas de Lindóia-SP, CD-ROM, Trabalho n.440, p.1589$1590,1999$.
} 


\section{CIÊNCIA DOS POLÍMEROS}

Neste capítulo serão abordadas algumas propriedades dos materiais poliméricos, bem como sua classificação, transições térmicas e propriedades mecânicas. Os polímeros possuem um comportamento bastante distinto dos materiais usualmente empregados em engenharia, como os metais, por exemplo. Por esse motivo, é de fundamental importância conhecer suas características, para o correto emprego desses materiais. Será dado um enfoque especial ao polietileno de alta densidade, material considerado neste estudo.

\section{1- CLASSIFICAÇÃO DOS POLÍMEROS}

Os polímeros são classificados de acordo com a sua origem, o grau de cristalinidade, a estrutura química, as características tecnológicas, o comportamento mecânico, o tipo de aplicação, etc.

\subsection{1- Classificação Quanto à sua Origem}

Quanto à forma de obtenção, os polímeros podem ser classificados em:

- $\quad$ Naturais: aqueles obtidos diretamente da natureza, como a celulose;

- $\quad$ Artificiais: aqueles que sofreram processo de modificação química dos polímeros naturais, como o celulóide;

- Sintéticos: aqueles que foram produzidos mediante o processo de polimerização, como as resinas fenólicas. 


\subsection{2- Classificação Quanto ao Grau de Cristalinidade}

No estado sólido, os termoplásticos apresentam dois tipos de morfologia diferentes: amorfo e cristalino. As moléculas de um polímero amorfo estão ordenadas aleatoriamente. Os polímeros cristalinos possuem fortes interações moleculares, sendo mais duros e resistentes. Os polímeros são considerados semicristalinos quando possuem em torno de $20 \%$ de cristalinidade. Para manter a possibilidade de moldagem, um polímero não pode ser totalmente cristalino, devido à elevada organização de sua estrutura.

O grau de cristalinidade afeta muitas propriedades poliméricas, da mesma forma com que algumas características poliméricas e o tipo de processamento afetam o grau de cristalinidade. À medida que características como peso molecular e ramificações poliméricas aumentam, o grau de cristalinidade diminui. O tempo, a tensão, a disposição das fibras na matriz, a direção da extrusão e o posicionamento das garras também são características que interferem no grau de cristalinidade.

\subsection{3- Classificação Quanto à Estrutura Química}

Em função da estrutura química, existem três tipos de classificações dos polímeros: em relação à composição molecular, em relação à estrutura química dos meros que constituem o polímero e em relação à estrutura molecular.

\section{a- Quanto à composição molecular}

Os polímeros são produzidos por meio de uma reação química conhecida por polimerização. Ela consiste na combinação de moléculas de monômeros, que podem ser iguais (homopolímeros) ou diferentes (copolímeros), formando cadeias compridas, sem alterar sua estrutura molecular.

O grau de polimerização do material é dado pelo número de meros que constitui a cadeia polimérica. Quanto maior for o grau de polimerização, mais elevado será o peso molecular do polímero. O elevado peso molecular dos altos polímeros afeta, significativamente, as propriedades físicas e químicas de suas moléculas, além de dificultar o seu processamento. 
Polímeros com baixo peso molecular são chamados de oligômeros, termo de origem grega, que significa poucas partes.

Os materiais que são formados pela união de três polímeros diferentes são conhecidos como terpolímeros. De acordo com a disposição dos meros na cadeia polimérica, os copolímeros podem ser diferenciados da seguinte forma:

- Copolímeros aleatórios: os meros, representados pelas letras A e B, são dispostos de maneira desordenada, na cadeia polimérica;

$$
-\mathrm{A}-\mathrm{A}-\mathrm{B}-\mathrm{A}-\mathrm{B}-\mathrm{B}-\mathrm{B}-\mathrm{A}-\mathrm{A}-\mathrm{B}-\mathrm{B}-\mathrm{A}-\mathrm{A}-\mathrm{A}-
$$

Figura 3.1: Copolímeros aleatórios. Fonte: www.jorplast. com.br/secoes/aulas-5.htm.

- Copolímeros alternados: os meros são dispostos de maneira ordenada;

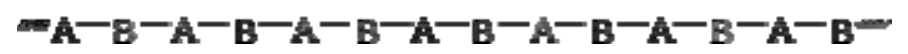

Figura 3.2: Copolímeros alternados. Fonte: www.jorplast. com.br/secoes/aulas-5.htm.

- Copolímeros em bloco: os meros iguais de comprimentos diferentes são dispostos em forma de longa seqüência, na cadeia polimérica;

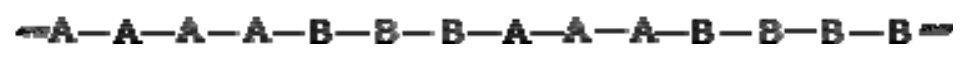

Figura 3.3: Copolímeros em bloco. Fonte: www.jorplast. com.br/secoes/aulas-5.htm.

- Copolímeros graftizados: meros iguais são dispostos na cadeia principal, enquanto outros tipos de mero formam as cadeias laterais.

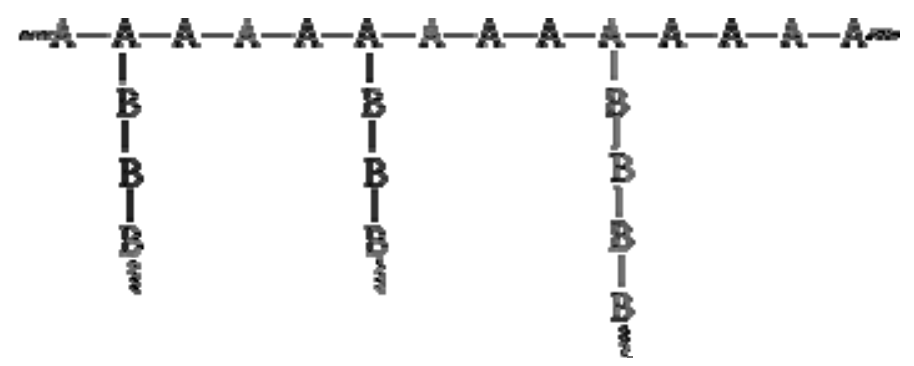

Figura 3.4: Copolímeros graftizados. Fonte: www.jorplast. com.br/secoes/aulas-5.htm. 


\section{b- Quanto à estrutura química dos meros que constituem o polímero}

Em função do grupo funcional a qual pertencem os meros na cadeia polimérica, tem-se:

- Poliolefinas - são os polímeros obtidos pelo processo de polimerização radicalizada das olefinas, que por sua vez são materiais poliméricos obtidos a partir dos hidrocarbonetos não-saturados. Elas possuem pouca polaridade, devido à falta de um grupo funcional, o que resulta uma baixa adesividade. São exemplos de poliolefinas: o polipropileno e o polietileno;

- Poliésteres - são os polímeros em forma de fibras sintéticas, obtidos por meio de uma reação de condensação entre um poliálcool e um ácido policarboxílico. São altamente cristalinos, além de possuírem propriedades como dureza, resistência abrasiva e mecânica, baixa absorção de umidade e baixo custo. São exemplos de poliésteres: o poli(tereftalato de etileno), o policarbonato e o poli(butileno tereftalato);

- $\quad$ Poliéteres - poli(óxido de etileno) e poli(óxido de fenileno);

- Poliamidas - são polímeros sintéticos termoplásticos, obtidos por meio da reação de dimerização de aminas alifáticas. Conhecidas como náilons, elas possuem boa resistência à água, boa flexibilidade, boa adesividade, boa resistência à abrasão, porém possuem baixa resistência térmica e química. Os náilons são exemplos de poliamidas;

- Polímeros celulósicos - são os polímeros com estrutura celular derivados de polímeros naturais, como o nitrato de celulose e o acetato de celulose. O processamento desses polímeros é feito por moldagem por injeção e a vácuo. Eles são muito utilizados em isolantes e brinquedos (Parente, 2006);

- Polímeros acrílicos - são os polímeros obtidos a partir do monômero ácido acrílico. Segundo Parente (2006), possuem elevada dureza, fragilidade e resistência ao intemperismo. São exemplos de polímeros acrílicos: o poli(metacrilato de metila) e o poliacrilonitrila; 
- Polímeros vinílicos - são os polímeros sintetizados a partir do monômero vinílico, tais como poli(acetato de vinila) (PVA) e poli(cloreto de vinila), um dos polímeros mais utilizados, devido a sua ampla diversidade em cores e propriedades conseguidas com a utilização de estabilizantes, lubrificantes, plastificantes, etc.;

- $\quad$ Poliuretano - é um polímero obtido a partir de uma reação de um di-isocianato aromático com um composto rico em grupos hidroxílicos, originando um produto sólido, com textura de espuma, que pode ser rígido ou flexível. Ele possui vantagens, como isolamento térmico e acústico, leveza e impermeabilidade;

- Resinas formaldeídicas - são materiais sintéticos obtidos pela reação entre fenol e formal. No ensaio de tração, esses materiais apresentam elevado módulo de elasticidade e baixa elongação na ruptura (Canevarolo, 2004). São exemplos de plásticos fenólicos: a resina fenolformol e a resina uréia-formol.

\section{c- Quanto à estrutura molecular}

A cadeia de um polímero é linear quando não possui ramificações, ou seja, a seqüência de meros é contínua. Já uma cadeia ramificada possui cadeias laterais ligadas à cadeia principal e, devido a essa ramificação, os polímeros possuem um menor grau de cristalinidade. A cadeia é dita reticulada quando a estrutura polimérica é tridimensional, com as cadeias unidas por ligações covalentes ou quando possuem muitas ligações cruzadas. As cadeias descritas estão ilustradas na figura 3.5 , respectivamente.

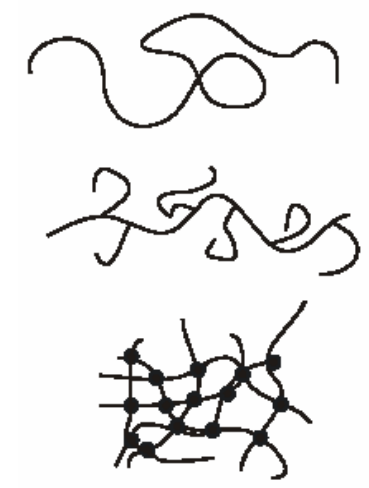

Figura 3.5: Tipos de configuração molecular: linear, ramificada, reticulada.

Fonte: www.jorplast. com.br/secoes/aulas-5.htm. 


\subsection{4- Classificação Quanto às Características Tecnológicas}

Em relação a este aspecto os polímeros podem ser divididos em: termoplásticos e termorrígidos (ou termofixos).

Termoplásticos são materiais que necessitam de calor para se tornarem moldáveis e, quando resfriados, adquirem a forma geométrica na qual foram moldados. O que torna esse material flexível é o enfraquecimento das forças intermoleculares, provocadas pelo aquecimento. A maior vantagem desse material é a possibilidade de repetição do ciclo de aquecimento e resfriamento, o que torna possível sua reciclagem.

Termofixos são plásticos que, após o processo de cura, providos ou não de aquecimento, não podem ser reamolecidos por outro aquecimento, devido à formação de ligações cruzadas. Portanto, não podem ser reciclados.

\subsection{5- Classificação Quanto ao Comportamento Mecânico}

Quanto ao comportamento mecânico, os polímeros podem dar origem aos plásticos, às fibras poliméricas e aos elastômeros (ou borrachas).

- Os plásticos, como descritos anteriormente, são materiais que em algum estágio, durante sua fabricação, adquiriram condição plástica a fim de serem moldados;

- As fibras poliméricas são termoplásticos orientados longitudinalmente, sendo que uma dimensão predomina sobre as demais. A razão de aspecto, isto é, o quociente entre o comprimento e o diâmetro da fibra, geralmente é maior ou igual a cem;

- As borrachas são materiais poliméricos amorfos, de origem natural ou sintética, que exibem elasticidade em longas faixas de deformação, à temperatura ambiente.

\subsection{6- Classificação Quanto ao Tipo de Aplicação}

Os termoplásticos podem ser divididos em: de uso geral, de engenharia ou de uso especial. 
- Plásticos de uso geral: são assim designados por serem consumidos em grande quantidade, além do baixo custo da resina, facilidade de processamento e por não necessitarem de elevado desempenho mecânico, para serem empregados;

- Plásticos de engenharia: são assim caracterizados por terem alto desempenho mecânico, apresentando diversas propriedades de engenharia, como rigidez, dureza, resistência ao impacto, entre outras. Além disso, o custo da matéria-prima é economicamente viável e não apresentam grandes dificuldades de processamento;

- Plásticos de uso especial: são os materiais desenvolvidos para atender determinados requisitos de serviço, que, por terem maior dificuldade no processamento e maior custo da resina, apresentam baixo nível de consumo, quando comparado com os demais.

\subsection{7- Classificação Quanto à Forma de Utilização}

Os polímeros podem ser divididos em classes de materiais, que na sua forma final de utilização geram como produtos:

- $\quad$ Plásticos: podem ser termoplásticos ou termofixos (ou termorrígidos);

- $\quad$ Fibras poliméricas;

- $\quad$ Borrachas;

- Espumas: são os materiais fabricados na forma celular, por meio de processos térmicos, químicos ou mecânicos, originando produtos com densidade entre 0,03 a $0,3 \mathrm{~g} / \mathrm{cm}^{3}$;

- Tintas: são os produtos resultantes de uma mistura estável de uma parte sólida com um componente volátil;

- Adesivos: são produtos que têm a função de manter materiais unidos, por adesão superficial, que é produzida pela existência de forças atrativas intermoleculares, com ação a curta distância. 


\section{2- PROPRIEDADES MECÂNICAS}

A substituição dos polímeros por outros materiais é normalmente baseada no conjunto de propriedades e características apresentadas por eles. É fundamental que um material polimérico apresente um desempenho mecânico satisfatório, durante a vida útil projetada para uma determinada aplicação.

O comportamento característico dos plásticos difere do comportamento dos materiais metálicos usuais. Apresentam não linearidade física, isto é, a relação força versus deslocamento não é linear, embora o material ainda não tenha ultrapassado seu limite de escoamento, mesmo para forças supostamente pequenas, pois os plásticos possuem grande flexibilidade, conforme o tipo de polímero e os aditivos usados na sua formulação. Portanto, não se deve assumir que uma peça plástica responderá como uma mola linear. Esse comportamento é alterado mais ainda devido às alterações de temperatura.

O comportamento mecânico de um material é dado pela sua resposta, quando submetidos a tensões ou deformações. As tensões e deformações não são simplesmente relacionadas por constantes de proporcionalidade. As respostas dos polímeros às solicitações mecânicas são dependentes de fatores estruturais (composição química, peso molecular, cristalinidade, orientação molecular ou reforços) e outras variáveis (condições de preparação e fabricação das amostras poliméricas, temperatura, velocidade de deformação, tipo de solicitação, intempéries, etc.).

Segundo Marczak (2004), as propriedades mecânicas mais importantes dos plásticos são:

- $\quad$ Módulo de elasticidade $(E)$ - tem um papel importante durante a seleção do material, por influir diretamente na rigidez do elemento. No caso dos plásticos, deve-se levar em conta que o módulo de elasticidade é muito mais suscetível a variações de temperatura do que nos metais, além de depender do tempo de carregamento. Como mostrado na figura 3.6, o módulo de elasticidade tangente é obtido no trecho elástico-linear, já o módulo de elasticidade secante é obtido através da reta que passa pela origem e pela deformação adotada. 


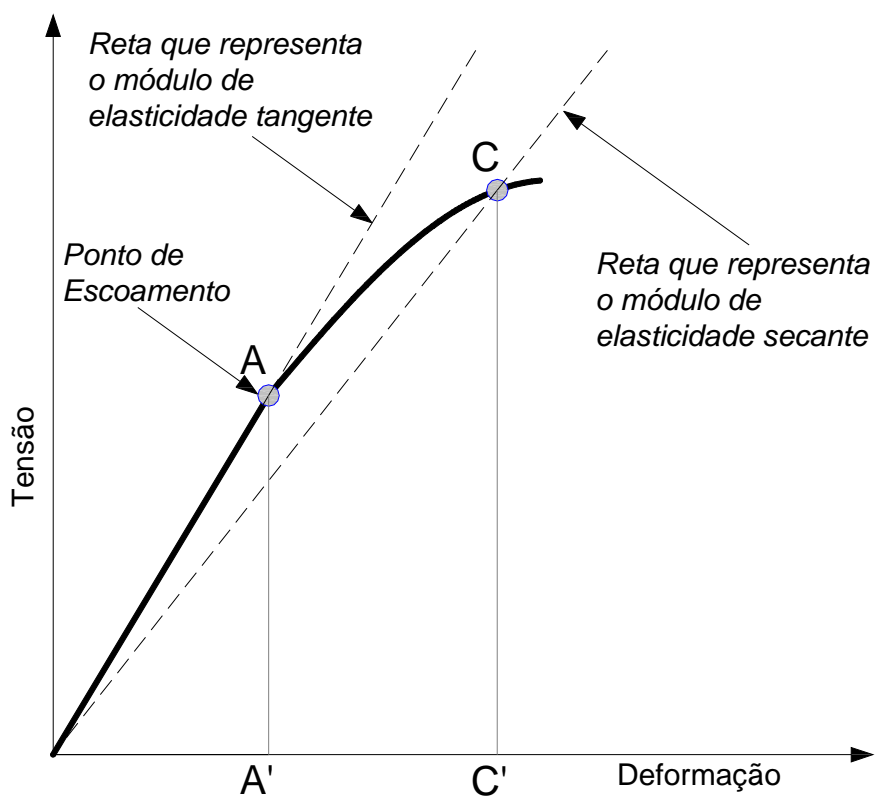

Figura 3.6: Módulos de elasticidade tangente e secante. Fonte: Crawford (1987).

- Resistência - a resistência dos polímeros também é altamente dependente da temperatura. No entanto, essa dependência não é a mesma para polímeros amorfos e para cristalinos. Outros aspectos que podem influir na resistência de um plástico são: velocidade de carregamento e fatores ambientais, como a umidade.

- $\quad$ Coeficiente de Poisson $(v)$ - é muito dependente da temperatura e do tempo de aplicação da carga. Sua faixa de variação é de 0,2 até 0,4 , para a maioria dos plásticos à temperatura ambiente, mas esses valores são extremamente sensíveis a alterações, devidas à composição química e à aditivação.

- $\quad$ Fluência - é o aumento da deformação ao longo do tempo, sob tensão constante. É uma característica típica dos plásticos, podendo ocorrer mesmo à temperatura ambiente, embora o fenômeno seja muito influenciado pela temperatura. Materiais termorrígidos resistem melhor à fluência do que os termoplásticos. Aditivos, como fibras de vidro e de carbono, reduzem drasticamente a fluência dos plásticos.

- Relaxação - é a diminuição da tensão ao longo do tempo, sob deformação constante. Este comportamento reflete um rearranjo das cadeias do polímero para se adaptar à 
força aplicada. Esta variável tem grande importância em aplicações como vedações, espaçadores, encaixes sob pressão e peças parafusadas, pois a força aplicada na montagem não será mantida constante, ao longo da vida do componente.

- Resistência à fadiga - depende da composição química do polímero e da temperatura, além da freqüência do carregamento e da amplitude das tensões e das deformações. Outro fator bastante significativo em polímeros é a histerese, que provoca mudanças de temperatura não controláveis durante o processo.

- $\quad$ Resistência ao impacto - segundo Agnelli (2005), uma das propriedades mais requisitadas para a especificação do comportamento mecânico dos polímeros é a resistência ao impacto, pois alguns plásticos são muito frágeis, quando comparados a outros materiais. $\mathrm{O}$ ensaio de resistência ao impacto tem o objetivo de comparar materiais para uma determinada aplicação.

Em relação ao tempo, devem-se considerar duas situações nos ensaios mecânicos:

- $\quad$ Ensaios de curta duração: são testes realizados com tempo de duração pequeno, geralmente com velocidade de aplicação de força ou velocidade de deformação padronizada (Ex: tração, compressão, flexão, cisalhamento e coeficiente de Poisson). O ensaio de resistência ao impacto é classificado como ensaio de curtíssima duração.

- $\quad$ Ensaios de longa duração: na maioria dos casos o tempo é a principal variável experimental dos ensaios. São caracterizados como ensaios mecânicos de longa duração: fluência, relaxação de tensão e fadiga. Esses ensaios podem ser realizados por meio de solicitações mecânicas de natureza estática ou dinâmica, ou seja, carregamento cíclico.

Além das propriedades mecânicas, existem outras propriedades dos materiais termoplásticos (www.incomplast.com.br/f_poliet.htm), tais como:

- Propriedades físicas: peso específico, temperatura mínima e máxima em uso contínuo, absorção de umidade;

- Propriedades mecânicas: dureza superficial (shore "A", "D”, Rockwell, Brinell), resistência à penetração de esfera, tensão de fluência e coeficiente de atrito; 
- Propriedades térmicas: calor específico, condutividade térmica, coeficiente de expansão térmica, temperatura máxima de uso em curto período, ponto de fusão, temperatura de transição vítrea, temperatura de fusão cristalina, entalpia, temperatura de distorção térmica, ponto de amolecimento "Vicat" e inflamabilidade;

- $\quad$ Propriedades elétricas: constante dielétrica, fator de perda dielétrica, resistividade volumétrica, rigidez dielétrica e resistência superficial;

- Propriedades químicas: resistência a ácidos fortes, resistência a ácidos fracos, resistência a bases fortes, resistência a bases fracas e resistência a raios solares.

\section{3- TRANSIÇÕES TÉRMICAS EM POLÍMEROS}

Devido à grande relação entre as propriedades térmicas dos polímeros com sua estrutura e sua composição molecular, elas são de extrema importância no desenvolvimento de um projeto de elementos compostos por materiais poliméricos. As transições térmicas são duas propriedades que se destacam, pois estão relacionadas com a mudança do estado físico dos materiais.

- Temperatura de transição vítrea, $\mathrm{T}_{\mathrm{g}}$ (glass transition temperature) - também conhecida por transição termodinâmica de $2^{\mathrm{a}}$ ordem, é caracterizada por ocorrer nas regiões amorfas. Devido a essa temperatura estar relacionada com a temperatura limite de trabalho dos materiais poliméricos, ela interfere em algumas propriedades, como módulo de elasticidade, coeficiente de expansão térmica, índice de retração, calor específico, etc.

- Temperatura de fusão cristalina, $\mathrm{T}_{\mathrm{M}}$ (melt transition temperature) - também conhecida por transição termodinâmica de $1^{\mathrm{a}}$ ordem, é caracterizada por ocorrer nas fases cristalinas, portanto só faz sentido para polímeros semicristalinos. Durante o aquecimento, a $\mathrm{T}_{\mathrm{M}}$ é dada pela média da faixa de temperatura em que desaparecem as regiões cristalinas, com a fusão dos cristalitos. Ela afeta propriedades como volume específico e entalpia.

No caso de termoplástico cristalizável, a cristalização ocorre entre a $T_{g}$ e a $T_{M}$, a um nível máximo conhecida por temperatura de cristalização TK, conforme a equação 3.1.

$$
T K \cong \frac{1}{2}\left(T_{g}+T_{M}\right)
$$


Tabela 3.1: Transição térmica dos polímeros. Fonte: Sichieri (1996 apud Silva, 2003).

\begin{tabular}{|c|c|c|}
\hline Polímeros & $\mathrm{T}_{\mathrm{M}}\left({ }^{0} \mathrm{C}\right)$ & $\operatorname{Tg}\left({ }^{\circ} \mathrm{C}\right)$ \\
\hline Politetrafluoretileno & 327 & -126 \\
\hline Polidimetilsiloxano & -54 & -123 \\
\hline Polietileno de baixa densidade & 110 & -120 \\
\hline Polietileno de alta densidade & 137 & -120 \\
\hline Polioximetileno & 175 & -73 \\
\hline Poliisobutileno & - & -70 \\
\hline Policloreto de vinilideno & 198 & -17 \\
\hline Polifluoreto de vinilideno & 171 & -35 \\
\hline Polifluoreto de vinila & 200 & -20 \\
\hline Polipropileno & 168 & -10 \\
\hline Poliacetato de vinila & - & 29 \\
\hline Policloreto de vinila & - & 85 \\
\hline Poli-4-metilpenteno 1 & 245 & 29 \\
\hline Policlorotrifluoretileno & 220 & 45 \\
\hline Poliamida 66 & 265 & - \\
\hline Poliamida 11 & 185 & - \\
\hline Polietileno tereftalato & 267 & 67 \\
\hline Polibutileno tereftalato & 228 & - \\
\hline Policloreto de vinila & - & 87 \\
\hline Poliestireno (isotático) & 240 & 100 \\
\hline Polissulfona & - & 190 \\
\hline Policarbonato & - & 150 \\
\hline Polioxifenileno & - & 210 \\
\hline Estireno-acrilonitrila & - & 105 \\
\hline Policloreto de vinila clorado & - & 100 \\
\hline Polivinil-butiral & - & 49 \\
\hline Polimetilmetacrilato & - & 105 \\
\hline Poli-p-xileno & 405 & - \\
\hline Polissulfeto de fenileno & 290 & - \\
\hline Poliacrilonitrila & 317 & 104 \\
\hline Etileno-propileno-fluorado & 290 & - \\
\hline
\end{tabular}

\section{4- POLIETILENO}

O polietileno, descoberto na Grã-Bretanha em 1933 e comercializado em 1939, é um dos plásticos mais vendidos e reciclados atualmente, devido às vantagens apresentadas por esse material, como a sua versatilidade (pode ser translúcido ou quase transparente, rígido ou flexível, natural ou pigmentado), a facilidade no seu processamento, o fato de não ser higroscópico e o seu 
preço reduzido. Além disso, é o único não tóxico dentre os termoplásticos (www.incomplast.com.br/f_poliet.htm).

O polietileno possui uma das mais simples estruturas dos polímeros existentes no mercado, o que lhe confere uma grande versatilidade em relação à variedade dos processos de transformação e aplicação, obtendo características próprias de densidade, peso molecular e distribuição de peso molecular. A figura 3.7 ilustra a estrutura de um polietileno.

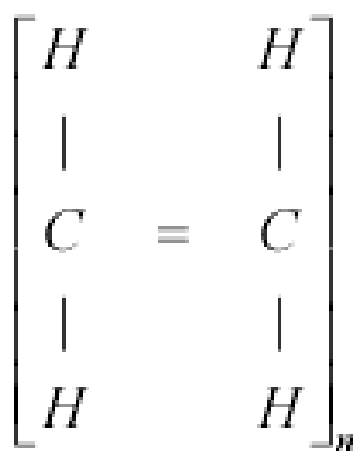

(a)

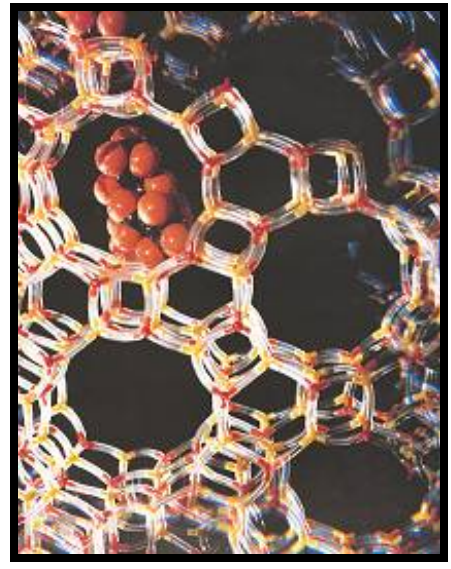

(b)

Figura 3.7: Estrutura do polietileno: (a) estrutura química; (b) estrutura molecular. Fontes: Marczak (2004); Valsani (1988).

Comercialmente são encontrados quatro tipos de polietileno (www.planetaplastico.com.br/pe.htm):

- $\quad$ Polietileno de baixa densidade (PEBD ou LDPE) - entre 0,910 a 0,925g/ $\mathrm{cm}^{3}$;

- $\quad$ Polietileno linear de baixa densidade (PELBD ou LLDPE) - entre 0,910 a $0,925 \mathrm{~g} / \mathrm{cm}^{3}$

- $\quad$ Polietileno de média densidade (PEMD) - entre 0,926 a $0,940 \mathrm{~g} / \mathrm{cm}^{3}$;

- $\quad$ Polietileno de alta densidade (PEAD ou HDPE) - maior que $0,941 \mathrm{~g} / \mathrm{cm}^{3}$.

Geralmente, o polietileno é obtido por meio da polimerização do monômero gasoso etileno $\left(\mathrm{CH}_{2}=\mathrm{CH}_{2}\right)$ em reator, sob determinadas condições de temperatura e pressão. O PEBD e alguns tipos de PEMD, caracterizados por um alto grau de ramificações longas e curtas ao longo 
da cadeia principal, são obtidos em processo de alta pressão. O PEAD e alguns tipos de PEMD, com ramificações em menor número e comprimento, são polimerizados em baixa pressão, bem como o PELDB.

O polietileno de alta densidade (PEAD) é a segunda resina mais reciclada no mundo. Aproximadamente $30 \%$ do consumo mundial de PEAD destinam-se a produtos oriundos da moldagem por sopro, sendo que a maior parte é representada em frascos para higiene e embalagens de produtos alimentícios (www.bndes.gov.br/conhecimento/relato/peadx.pdf).

Isso ocorre devido ao aumento do consumo mundial do PEAD, a uma taxa média de $7,8 \%$ ao ano, no período de 1984 a 1995, chegando a alcançar uma demanda de 16 milhões de toneladas, conforme mostra a figura 3.8. As regiões da América do Norte, Europa Ocidental e Japão são as responsáveis pelo consumo mundial de 60\% de PEAD (figura 3.9).

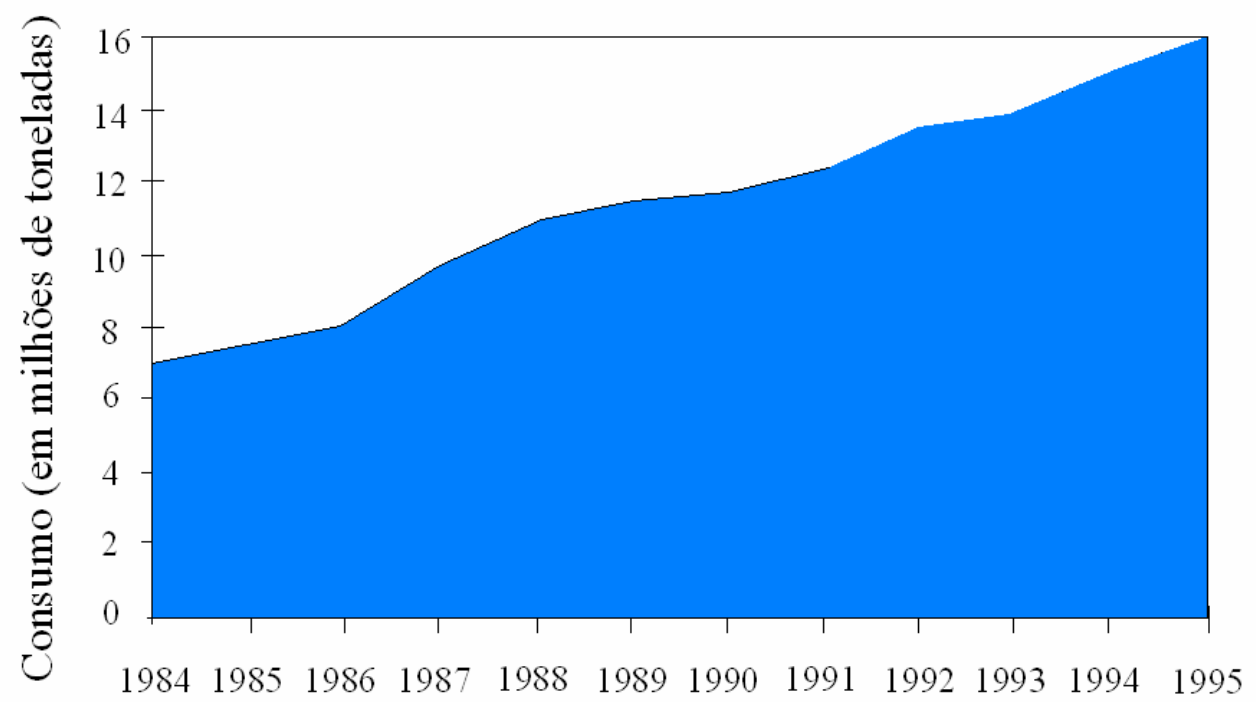

Figura 3.8: Consumo Mundial de Polietileno de Alta Densidade (1984 - 95).

Fonte: www.bndes.gov.br/conhecimento/relato/peadx.pdf. 


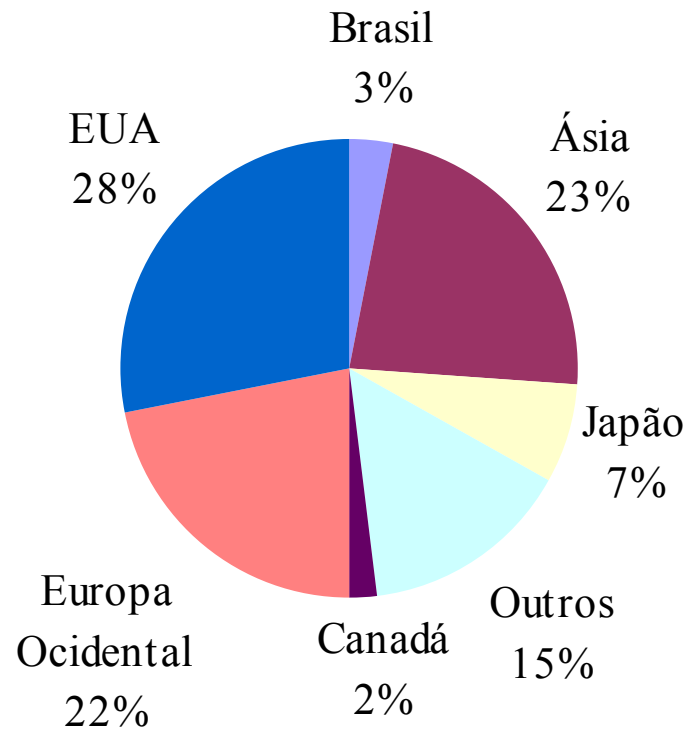

Figura 3.9: Participação do Consumo de PEAD por Região em 1995.

Fonte: www.bndes.gov.br/conhecimento/relato/peadx.pdf.

A fusão no PEAD ocorre em temperatura mais alta, devido a ele possuir maior cristalinidade em relação ao PEBD. Portanto a orientação, o alinhamento e o empacotamento das cadeias são mais eficientes e as forças intermoleculares (Van der Waals) agem mais intensamente (Coutinho et. al., 2003).

Tabela 3.2: Características do polietileno de baixa e alta densidade. Fonte: Canevarolo (2004).

\begin{tabular}{ccccc}
\hline Polímero & Abreviatura & $\begin{array}{c}\text { Temperatura de } \\
\mathbf{f u s a ̃ o}\left({ }^{\mathbf{0}} \mathbf{C}\right)\end{array}$ & $\Delta \mathbf{H}_{\mathbf{f}}{ }^{\mathbf{0}}(\mathbf{J} / \mathbf{g})$ & $\begin{array}{c}\text { Cristalinidade } \\
\mathbf{( \% )}\end{array}$ \\
\hline $\begin{array}{c}\text { Polietileno de baixa } \\
\text { densidade }\end{array}$ & PEBD & $83 \ldots 105$ & 140 & $40 \ldots 68$ \\
\cline { 2 - 5 } & & $105 \ldots 120$ & 140 & $45 \ldots 75$ \\
\hline $\begin{array}{c}\text { Polietileno de alta } \\
\text { densidade }\end{array}$ & PEAD & $130 \ldots 130$ & 140 & $75 \ldots 85$ \\
\hline
\end{tabular}

(*) Valor mais freqüentemente mencionado na literatura para o PEAD 100\% hipoteticamente cristalino.

As propriedades mais relevantes do PEAD (www.planetaplastico.combr/pe.htm) são elevadas resistências química, mecânica e ao stress cracking, além de elevadas características de rigidez, fluência, abrasão, impacto e fendilhamento sob tensão ambiental. Na tabela 3.3, estão listadas algumas das propriedades mecânicas do PEAD. As propriedades mecânicas fornecidas pela Ipiranga Petroquímica são referentes ao PEAD proveniente de embalagens moldadas a 
sopro, com os corpos-de-prova moldados por compressão. As demais referências não especificam a origem do material e o processo de obtenção dos corpos-de-prova.

Tabela 3.3: Propriedades mecânicas do PEAD.

Fonte:http://www.ipq.com.br/index.php? $s e c a o=$ catalogo $\&$ resina $=$ pead $\&$ processo $=9 \&$ produto $=10$.

\begin{tabular}{lccc}
\hline \multicolumn{1}{c}{ Propriedades Mecânicas } & Unidades & Normas & Valores \\
\hline Tensão no escoamento à tração (em placa) & $\mathrm{MPa}$ & ASTM D638 - 03 & 28 \\
\hline Tensão na ruptura à tração (em placa) & $\mathrm{MPa}$ & ASTM D638 - 03 & 29 \\
\hline Tensão na ruptura à compressão* & $\mathrm{MPa}$ & ASTM D695 & 20 \\
\hline Resistência à compressão ** & $\mathrm{MPa}$ & ASTM D695 & 17 \\
\hline Resistência à flexão ** & $\mathrm{MPa}$ & ASTM D790 & $14-20$ \\
\hline & $\mathrm{MPa}$ & DIN 53457 \\
Módulo de elasticidade à tração* & ASTM D638 & 900 \\
& $\mathrm{MPa}$ & ASTM D627 & \\
\hline Módulo de elasticidade à compressão & $\mathrm{MPa}$ & --- \\
\hline Módulo de flexão secante a 2\% (em placa) & ASTM D790 - 03 & 1040 \\
\hline Alongamento na ruptura (em placa) & $\%$ & ASTM D638 - 03 & 860 \\
\hline Resistência ao impacto Izod & $\mathrm{J} / \mathrm{m}$ & ASTM D256 - 03 & 140 \\
\hline *Fonte: www.incomplast.com.br/f_poliet.htm. & & \\
** Fonte: www.planetaplastico.com.br/litera/prop fisicas. & \\
\hline
\end{tabular}

Enquanto as propriedades elétricas são pouco afetadas pela densidade e pelo peso molecular do polímero, as propriedades mecânicas sofrem uma forte influência do peso molecular, do teor de ramificações, da estrutura morfológica e da orientação.

\section{5- CONSIDERAÇÕES FINAIS}

Pode-se perceber que os polímeros possuem um comportamento mecânico muito específico, o que os difere dos materiais convencionais, sendo que a distinção entre seus diversos tipos se dá por meio das transições térmicas.

A grande quantidade de polímeros existentes, juntamente com os polímeros que surgem a cada dia, por meio de pesquisas científicas e tecnológicas, gera a necessidade de sua classificação em grupos com características comuns, a fim de facilitar a compreensão e o estudo das propriedades desses materiais. 


\section{COMPÓSITOS}

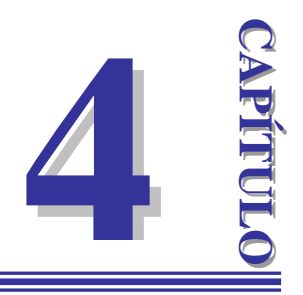

Os materiais oriundos do emprego de cargas minerais e de fibras em uma matriz são denominados materiais compósitos. Portanto, um compósito é um material formado pela combinação de dois ou mais micro ou macro constituintes, diferentes na forma e na composição química, além de serem, na maioria dos casos, insolúveis um no outro. Geralmente, um compósito é formado por uma fase contínua, a matriz, e por uma fase dispersa, o reforço.

Existem diversos tipos de materiais compósitos, podendo dividi-los nos seguintes grupos, (www.azom.com/details.asp):

- $\quad$ Compósitos de matriz cerâmica;

- $\quad$ Compósitos de matriz metálica;

- $\quad$ Compósitos de matriz polimérica;

- Asfaltos;

- $\quad$ Madeira; etc.

\section{1- REFORÇOS}

A importância de adicionar um reforço à matriz polimérica deve-se principalmente às vantagens desse material de reforço, como elevada rigidez e resistência em relação à matriz polimérica, e tamanho, forma e características da superfície da partícula, a fim de proporcionar uma efetiva ligação mecânica. As propriedades do compósito são altamente dependentes da interação polímero/reforço, sendo que o reforço deve preservar as características da matriz polimérica. 
Segundo Hollaway (2003), pode-se dizer que as propriedades dos compósitos dependem:

- $\quad$ Das propriedades do reforço;

- $\quad$ Das propriedades da resina;

- Da taxa de reforço adicionada à resina;

- Da geometria e da orientação do reforço na resina,

- $\quad$ Do método de processamento do compósito.

$\mathrm{Na}$ maioria dos casos, as propriedades mecânicas do reforço, resistência e módulo de elasticidade, são bem maiores do que as propriedades da resina. Portanto, seria sensato dizer que, à medida que aumenta o teor de reforço, as propriedades mecânicas do compósito são melhoradas, mas na prática isso nem sempre acontece. $\mathrm{O}$ teor de reforço a ser adicionado à matriz depende do tipo de processo utilizado para misturar os componentes, além de ser influenciado pelo tipo de resina e pela forma com que o reforço é incorporado à matriz.

Existem limites ideais para que o reforço seja totalmente encapsulado pela resina, obtendo-se um compósito com a maior eficiência possível. Geralmente, o teor de reforço a ser empregado varia entre 30 e $40 \%$ em volume (www.azom.com/details.asp).

Conhecendo bem as propriedades mecânicas dos compósitos, é possível empregá-los na indústria da construção, desde que as deformações e os deslocamentos estejam dentro das prescrições funcionais e estéticas, e, principalmente, que não ocorra ruína, durante a vida útil prevista para a estrutura.

\section{2- TIPOS DE REFORÇOS}

Em função da eficiência do reforço mecânico, as fibras e as cargas minerais podem ser classificadas da seguinte maneira (Sousa, 2005):

- $\quad$ Fibras de reforço: são as fibras de módulo e resistência elevada, como as fibras de vidro, de carbono, de aramida, etc.; 
- Cargas minerais reforçantes: são minerais com estrutura fibrosa ou lamelar, como mica, talco, caulim, etc.;

- Cargas minerais de enchimento: são também conhecidas como cargas funcionais, pois sua função principal é baratear o custo da matriz polimérica. São os minerais com formato esferoidal, como sílica, quartzo, alumina, etc.

O melhor reforço é aquele que atende as características de projeto, com o menor custo.

\subsection{1- Fibras}

A utilização de fibras como reforço nos materiais termoplásticos está crescendo cada vez mais, devido às vantagens que elas apresentam, como maior tenacidade, maior resistência mecânica, maior módulo de elasticidade, maior resistência ao impacto, boa estabilidade estrutural e bom comportamento à fadiga, baixa expansão térmica, facilidade de armazenamento e de reparação, além de serem recicláveis e de não necessitarem de reações químicas para o seu processamento. Porém, a rigidez e a resistência são os parâmetros principais que aumentam com a incorporação de fibras (Sousa, 2005).

A "Regra da Mistura" é o tratamento teórico mais simplificado para obtenção do módulo longitudinal e da resistência à tração do compósito, na direção paralela às fibras. Esses parâmetros são dados pelas equações 4.1 e 4.2 , respectivamente.

$$
\begin{aligned}
& E_{c}{ }^{\prime}=E_{f}{ }^{\prime} \times V_{f}+E_{m} \times\left(1-V_{f}\right) \\
& \sigma_{c}{ }^{\prime}=\sigma_{f}{ }^{\prime} \times V_{f}+\sigma^{\prime}{ }_{m} \times\left(1-V_{f}\right)
\end{aligned}
$$

Nessas equações têm-se:

$\mathrm{E}_{\mathrm{c}}{ }^{\prime}, \mathrm{E}_{\mathrm{f}}^{\prime}, \mathrm{E}_{\mathrm{m}}-$ Módulos de elasticidade do compósito, da fibra e da matriz, respectivamente;

$\sigma_{\mathrm{c}}{ }^{\prime}, \sigma_{\mathrm{f}}{ }^{\prime}-$ Resistências do compósito e da fibra à tração;

$\sigma_{m}^{\prime}$ - Tensão da matriz na deformação máxima da fibra; 
$\mathrm{V}_{\mathrm{f}}$ - Fração da fibra em volume.

Essa regra só é válida para fibras longas, alinhadas numa única direção, e o compósito ensaiado na direção paralela às fibras. Porém, como isso nem sempre ocorre, deve ser introduzido um fator de correção $(\eta)$ nas equações 4.1 e 4.2, obtendo-se as equações 4.3 e 4.4 :

$$
\begin{aligned}
& E_{c}^{\prime}=E_{f}{ }^{\prime} \times V_{f} \times \eta+E_{m} \times\left(1-V_{f}\right) \\
& \sigma_{c}{ }^{\prime}=\sigma_{f}{ }^{\prime} \times V_{f} \times \eta+\sigma_{m}^{\prime} \times\left(1-V_{f}\right)
\end{aligned}
$$

Nas quais:

$\eta=1$ - Para fibras totalmente alinhadas e o compósito ensaiado na direção do alinhamento;

$\eta=1 / 6-$ Para fibras totalmente aleatórias nas três direções;

$\eta=1 / 3-$ Para fibras aleatórias em apenas um plano;

$\eta<1 / 6$ - Para fibras alinhadas, com o compósito ensaiado na direção perpendicular à direção de alinhamento.

O reforço da matriz pela adição de fibras ocorre por meio de um mecanismo de transferência de tensão, da matriz para as fibras, sendo que a matriz recebe o carregamento, transferindo-o para as fibras, além de protegê-las, por meio do encapsulamento, e de dispersá-las, o que dificulta a propagação das fissuras (Hollaway, 1993). Esse mecanismo pode ser melhorado pela adição de colas, aglutinantes ou agentes especiais de acoplamento, já que a interface da fibra com a matriz é uma região de transição anisotrópica. O diâmetro das fibras também influencia na transferência de esforços, pois pequenos diâmetros, por terem maior área superficial por unidade de peso, melhoram a transferência de tensão do compósito.

Quando se introduzem fibras curtas, ou seja, descontínuas, na matriz, a transferência da tensão ocorre da matriz para as fibras por meio do atrito e cisalhamento na interface polímeroreforço (Sousa, 2005). Essa transferência é uniforme ao longo do comprimento da fibra. Nessas fibras, os fatores mais importantes são: o comprimento real da fibra e a adesão interfacial polímero-fibra. 
A tensão transferida da matriz para a fibra é completa no comprimento crítico da fibra $\left(\ell_{c}\right)$ ou na razão de aspeto crítica $\left(\ell /\right.$ d) , dada pela equação, 4.5 , de Kelly e Tyson, segundo Chawla ${ }^{*}$ (1998 apud Sousa, 2005).

$$
\left(\frac{\ell}{d}\right)_{c}=\frac{\sigma_{f}^{\prime}}{2 \tau}
$$

Nas quais:

$\sigma_{f}^{\prime}-$ Tensão na fibra;

$\tau$ - Resistência ao cisalhamento na interface polímero-fibra ou da matriz, sendo que o menor valor define o comprimento crítico.

Portanto a equação 4.2 pode ser reescrita da seguinte forma.

$$
\sigma_{c}^{\prime}=\sigma_{f}{ }^{\prime} \times V_{f} \times\left(1-\frac{\ell_{c}}{2 l}\right)+\sigma_{m}^{\prime} \times\left(1-V_{f}\right)
$$

$\ell$ - comprimento real da fibra.

Sendo que:

- $\quad \ell>>\ell_{\mathrm{c}}-$ Reforço máximo, equivalente ao das fibras longas;

- $\quad \ell>\ell_{\mathrm{c}}-$ Aumento da resistência do compósito;

- $\quad \ell<\ell_{\mathrm{c}}-$ Redução da resistência do compósito.

A fibra de vidro, figura 4.1, é uma fibra inorgânica de elevado desempenho e a mais utilizada em compósitos poliméricos, devido à combinação de propriedades que ela oferece ao compósito, como elevada resistência e rigidez, com baixo custo, quando comparada com as fibras

\footnotetext{
${ }^{*}$ Composite materials: Science \& Engineering, K.K. Chawla, 2a edição, Springer-Verlag, New York, 1998.
} 
de carbono e de aramida. Existem também as fibras naturais, como algodão, sisal, juta, coco, etc., e as fibras sintéticas, como nylon, poliéster, acetato e rayon.

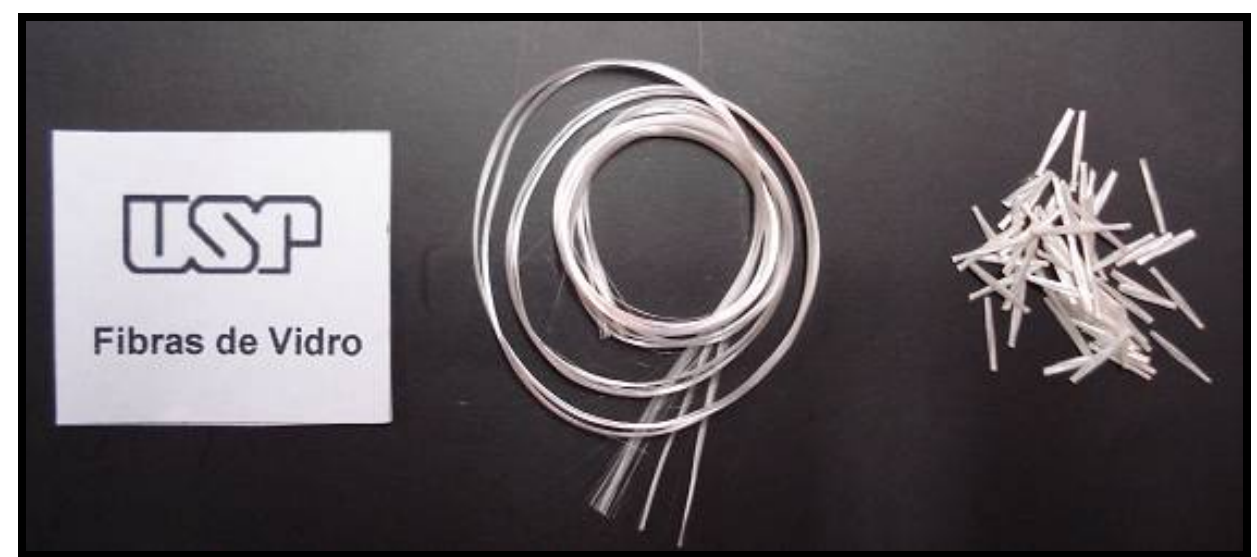

Figura 4.1: Fibras de vidro em duas formas distintas.

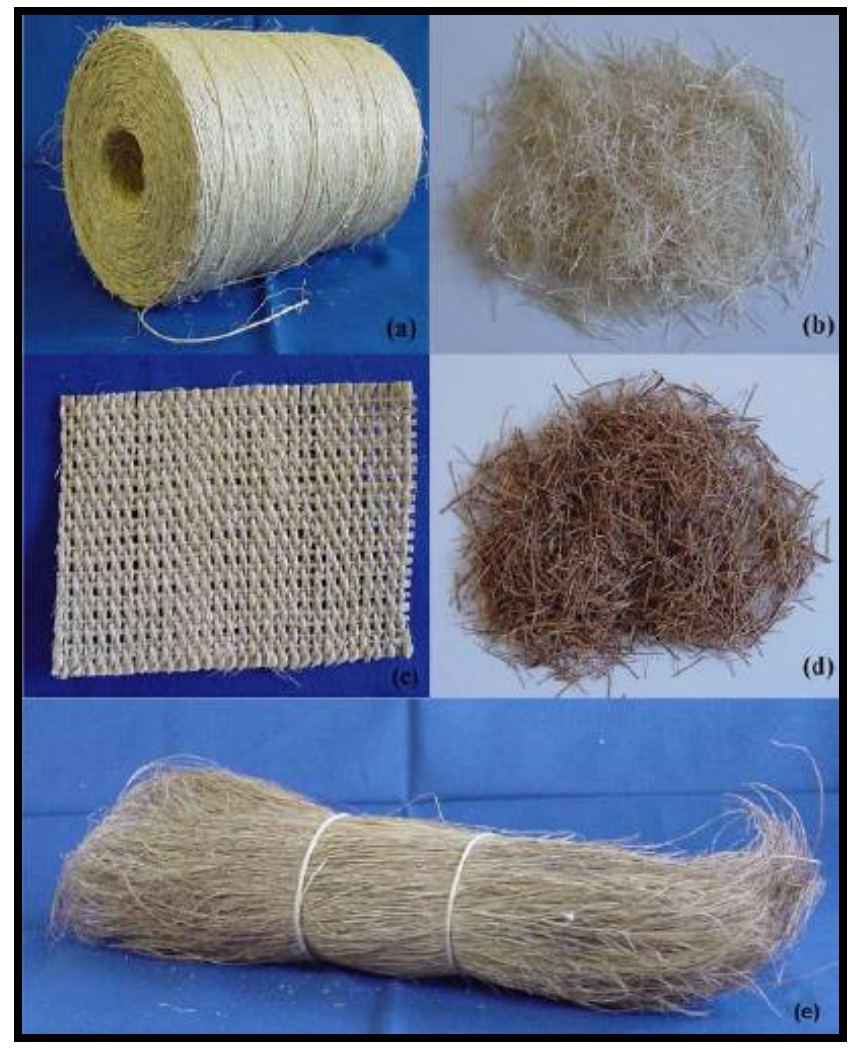

Figura 4.2: Fibras de sisal e de coco nas suas diferentes formas. (a) bobina de fios de sisal; (b) fibras curtas de sisal; (c) tecido de sisal; (d) fibras curtas de coco; (e) fibras de coco penteadas. Fonte: Silva (2003). 
Tabela 4.1: Propriedades mecânicas das fibras de vidro, de aramida e de carbono. Fonte: Hollaway (1993).

\begin{tabular}{ccccccc}
\hline \multirow{2}{*}{ Material } & Fibras & $\begin{array}{c}\text { Módulo de } \\
\text { Elasticidade } \\
(\mathbf{G P a})\end{array}$ & $\begin{array}{c}\text { Resistência } \\
\text { à Tração } \\
(\mathbf{M P a})\end{array}$ & $\begin{array}{c}\text { Deformação } \\
\text { na Ruptura } \\
\mathbf{( \% )}\end{array}$ & $\begin{array}{c}\text { Densidade } \\
\left(\mathbf{g} / \mathbf{c m}^{\mathbf{2}}\right)\end{array}$ & $\begin{array}{c}\text { Temperatura } \\
\text { Máxima } \\
\left({ }^{\mathbf{0}} \mathbf{C}\right)\end{array}$ \\
\hline \multirow{3}{*}{ Vidro } & $\mathrm{E}$ & 72,4 & 2400 & 3,5 & 2,55 & 250 \\
\cline { 2 - 7 } & $\mathrm{A}$ & 72,4 & 3030 & 3,5 & 2,50 & 250 \\
\cline { 2 - 7 } & $\mathrm{S}-2$ & 88 & 4600 & 5,7 & 2,47 & 250 \\
\hline $\begin{array}{c}\text { Aramida } \\
\text { (Kevlar) }\end{array}$ & 48 & 125 & 2760 & 2,4 & 1,44 & 180 \\
\hline Carbono & XASHS & 23 & 2750 & 4,0 & 1,44 & 180 \\
\hline
\end{tabular}

As fibras de vidro longas, $\ell>5$ a $10 \mathrm{~mm}$, possuem resistência à flexão maior do que as fibras curtas, $\ell \approx 0,2$ a $1 \mathrm{~mm}$, já que as primeiras se aproximam mais das fibras contínuas, como pode ser observado na tabela 4.2 .

Tabela 4.2: Efeito do reforço de fibras longas e curtas na resistência à flexão.

Fonte: Maxwell* (1983 apud Sousa, 2005).

\begin{tabular}{ccccc}
\hline \multirow{2}{*}{ Polímero } & Fibra & Matriz pura & Resistência à Flexão (MPa) \\
& & $30 \%$ fibra curta & $\mathbf{6 5 \%}$ fibra longa \\
\hline PP & Vidro & 33 & 86 & 350 \\
\hline PET & Vidro & 60 & 140 & 800 \\
\hline PA 66 & Vidro & 85 & 180 & 650 \\
\hline PES & Vidro & 90 & 145 & 500 \\
\hline PEEK & Vidro & 91 & 150 & 780 \\
\hline PEEK & Carbono & 91 & 215 & 1100 \\
\hline
\end{tabular}

$\mathrm{Na}$ figura 4.3 são apresentados os dados de tensão e de deformação para alguns tipos de fibra (Hollaway, 2003). Numa análise comparativa, pode-se perceber que a fibra de aramida (Kevlar 49) é a que suporta maior tensão, e que a fibra de vidro é a que possui maior deformação, quando sujeita a um carregamento.

\footnotetext{
* Maxwell, J. - "The drive for plastics: competing in performance", plastics and rubber international, v. 8, n.2, pp. 4549, April (1983).
} 


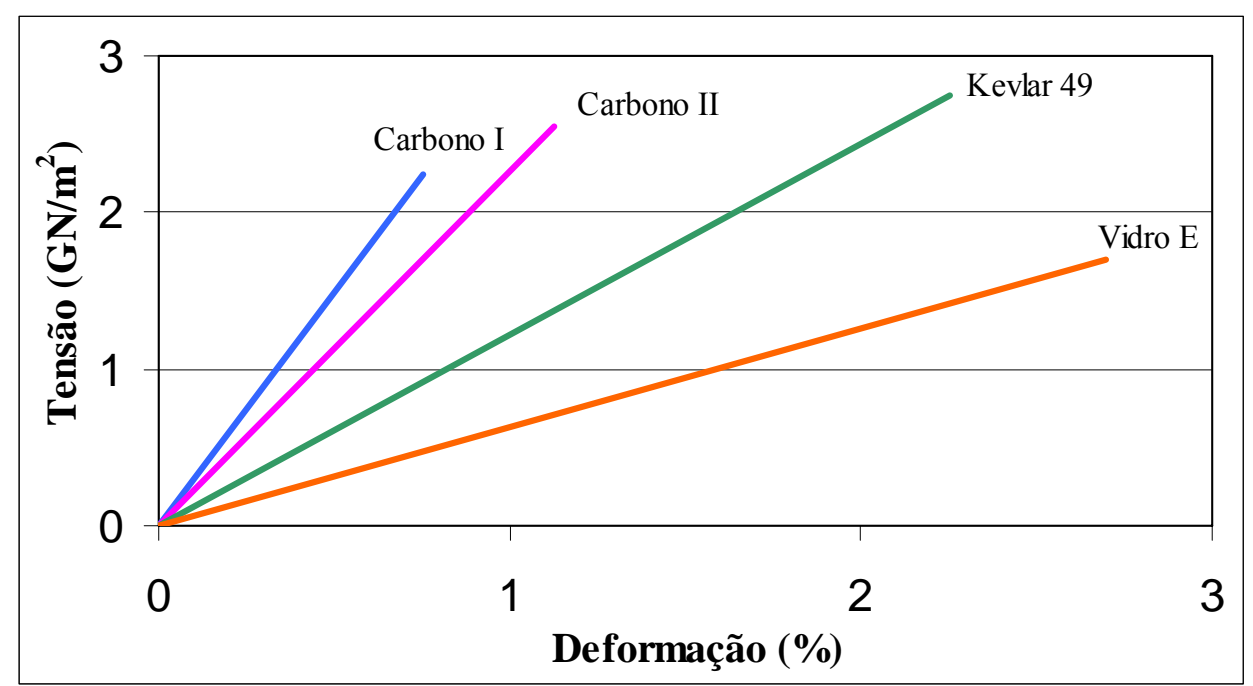

Figura 4.3: Gráfico tensão $x$ deformação de algumas fibras termoplásticas. Fonte: Hollaway (2003).

Materiais como vidro, boro e aramida, na forma contínua, não possuem resistência, pois, quando submetidos a tensões, ocorrem falhas de superfície, facilitando o aparecimento de fissuras e trincas. Por isso, esses materiais são introduzidos na forma de fibras.

As propriedades dos compósitos dependem de vários fatores, como: tipo de fibra, fração volumétrica, razão de aspecto, densidade, adesão interfacial, etc. O tamanho das fibras está ligado com o ganho das propriedades, sendo classificadas em contínuas e descontínuas, sendo as descontínuas classificadas em curtas e longas, conforme ilustrado na figura 4.4.

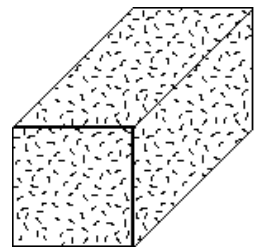

(a)

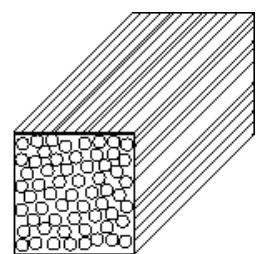

(b)

Figura 4.4: Classificação das fibras quanto ao tamanho: (a) fibras curtas; (b) fibras longas.

Fonte: www.efunda.com/formulae/solid_mechanics/composites.

Como as tensões e as deformações de cisalhamento na interface fibra/matriz são responsáveis pela transferência dos esforços em compósitos, as fibras longas geralmente proporcionam maiores ganhos de resistência e de rigidez do que as fibras curtas e as particuladas. Porém, elas requerem tipos de processamento especiais, para desempenhar tal papel. 
Um compósito reforçado com fibra sempre exibe certo grau de anisotropia. Isto significa que muitas propriedades do compósito dependem da direção em que os esforços são medidos.

Com o aumento da resistência, a utilização dos termoplásticos reforçados com fibras está sendo empregada na construção civil. Já existem algumas aplicações, principalmente em passarelas. Entretanto, inúmeros projetos de pesquisas têm sido desenvolvidos, como o ASSET (Advanced Structural SystEms for Tomorrow's Infrastructure), um projeto de pesquisa europeu fundado em outubro de 2002, por Muchel, que desenvolveu uma tecnologia para empregar os compósitos reforçados com fibras em uma ponte no Reino Unido (figura 4.5).

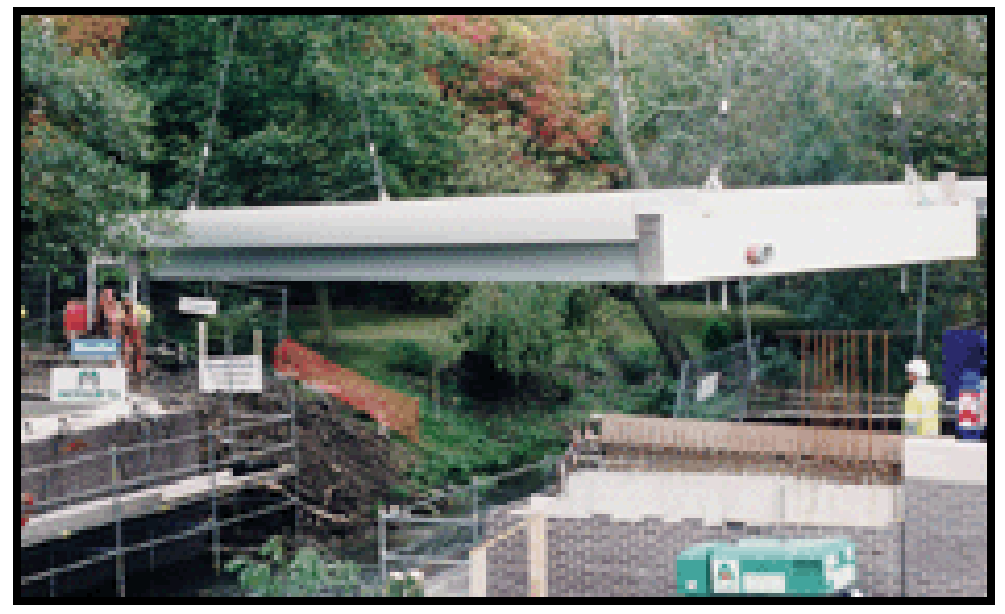

Figura 4.5 : Ponte West Mill em Oxford, Reino Unido.

Fonte: www.reinforcedplastics.com/market_focus/construction/Asset_bridge.html.

Além disso, os compósitos reforçados com fibras podem ser aplicados em diversas obras estruturais, como estacionamentos, tabuleiros de pontes, plantas industriais, etc.

\subsection{2- Cargas}

Cargas são substâncias particuladas de origem natural e de característica inorgânica, adicionadas à matriz polimérica, com a finalidade de alterar suas propriedades físicas e mecânicas. Elas se diferem das fibras devido à condição geométrica, ou seja, pequena relação entre comprimento e diâmetro. Quanto à forma, as cargas são classificadas em esféricas, laminares, filler, além de outros formatos. 


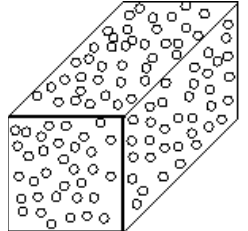

(a)

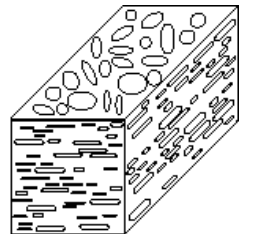

(b)

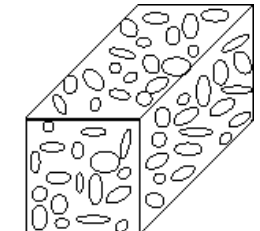

(c)

Figura 4.6: Classificação das cargas quanto ao formato: (a) partículas; (b) flake e (c) filler. Fonte: www.efunda.com/formulae/solid_mechanics/composites.

Durante algum tempo, segundo Sousa (2005), esse material era empregado com a principal função de redução de custo do produto final, já que diminuia a quantidade de polímero empregada. Porém, com o passar do tempo, outras funções foram atribuídas a esses materiais, como aumento de rigidez, de resistência à flexão, temperatura de distorção térmica (HDT), condutividade térmica e dureza, passando a ser denominadas de cargas reforçativas.

Outras propriedades podem ser alcançadas, dependendo do tipo de reforço particulado a ser empregado. As principais são: aumento de resistência à tração, à flexão, à abrasão, química e ao impacto, além de diminuir o encolhimento e o empenamento de peças moldadas.

Geralmente, os reforços particulados são beneficiados antes de serem incorporados como cargas, sendo que os reforços minerais mais importantes são os carbonatos de cálcio, argilas e talcos (Sousa, 2005).

Segundo Souza (2005), existem alguns fatores que, muitas vezes, limitam o uso de fibras e de cargas minerais, reforçantes ou de enchimento, em matrizes poliméricas:

- Difícil processabilidade e ação abrasiva nos equipamentos de compostagem e transformação de termoplásticos, principalmente a teores elevados de reforço incorporado;

- Queda acentuada na resistência ao impacto e tenacidade e/ou ductilidade do compósito, principalmete em matrizes de termoplásticos tenazes;

- Efeito de anisotropia nas propriedades mecânicas e empenamento de peças moldadas, principalmente a elevados teores de fibras incorporadas. Esses efeitos podem ser minimizados pela combinação criteriosa de cargas minerais com fibras. 


\section{3- ADITIVOS}

Um material polimérico reciclado, além de resíduos, pode conter diversos aditivos não poliméricos. Com exceção dos aditivos usados em maiores teores, plastificantes, pigmentos e cargas em torno de $1 \mathrm{phr}$ (per hundred resin - partes por 100 partes de resina), segundo Mendes et al. (2000), os demais não afetam a identificação do polímero-base.

Aditivos são produtos químicos adicionados aos plásticos, a fim de alterarem suas propriedades específicas. Compostos são produtos oriundos da mistura do polímero com os aditivos que, embora sejam adicionados em pequena quantidade, são muito importantes devido às contribuições que podem dar ao produto final, como alteração da cor, desmoldagem fácil, melhoria de propriedades.

Colorantes, plastificantes, estabilizantes, lubrificantes, retardanes de chama são exemplos de aditivos que podem ser incorporados aos polímeros.

\section{a) Colorantes}

São substâncias químicas que, quando incorporadas, alteram a cor de um material. Os colorantes podem ser divididos em corantes e pigmentos, sendo que os corantes são as substâncias solúveis no polímero, e os pigmentos, as insolúveis, que por sua vez são classificados em orgânicos e inorgânicos. Geralmente eles são utilizados por razões de estética, e sua escolha é dada em função da compatibilidade com o material base.

\section{b) Plastificantes}

São aditivos líquidos incolores e inodoros, não voláteis, com baixa solubilidade em água. Sua principal função é alterar as propriedades mecânicas do produto final, como aumentar a deformabilidade e diminuir a fragilidade, além de facilitar as condições de processamento dos plásticos, já que permitem abaixar a temperatura de transformação Rocha* (1990 apud Silva, 2003). 
c) Estabilizantes

São aditivos incorporados aos polímeros para protegê-los contra a degradação provocada pelo calor e pelas solicitações mecânicas a que o produto está sujeito.

d) Estabilizantes de ultravioleta

São os aditivos que oferecem proteção contra os raios ultravioleta, inibindo sua ação, por meio de películas protetoras que os absorvem. Além dessa película, pode-se incorporar substâncias absorventes à matriz polimérica. Os estabilizantes de ultravioleta são essenciais para elementos estruturais expostos à exteriores.

\section{e) Lubrificantes}

São adicionados à matriz polimérica para facilitar o processo de desmoldagem. Segundo Rocha $^{*}$ (1990 apud Silva, 2003), os mais comuns são: o óleo de soja epoxidado, o ácido esteárico e os estearatos de chumbo e de cádmio.

\section{f) Retardantes de chama}

São aditivos incorporados durante a etapa de processamento do polímero. Essa técnica de incorporação altera quimicamente, fisicamente ou de ambas as formas, nas fases líquida, sólida ou gasosa, interferindo no processo de queima. A interferência química é o processo de combustão mais eficiente para os retardantes de chama.

Deve-se também conhecer bem o material polimérico e a funcionalidade do produto, para escolher o retardante de chama mais adequado a ser incorporado. Os aditivos retardantes de chama mais utilizados são: hidróxido de alumínio, boratos, fosfatos, organo-halogenados, trióxido de antimônio e de magnésio.

*ROCHA, Adélia C. P. F. (1990). Materiais plásticos para a construção civil. Lisboa, LNEC (Laboratório Nacional de Engenharia Civil) - ICT - informação científica. 


\section{4- CONSIDERAÇÕES FINAIS}

Rigidez, resistência mecânica, tenacidade e resistência ao impacto são alguns dos fatores que muitas vezes limitam o emprego dos materiais termoplásticos em aplicações de engenharia. A utilização de blendas poliméricas, a adição de cargas minerais e de fibras de elevado módulo e resistência e a incorporação de aditivos são possíveis soluções para melhoria das propriedades mecânicas dos materiais termoplásticos (Sousa, 2005). 


\section{MATERIAIS E MÉTODOS}

Os ensaios que serão descritos ao longo deste capítulo foram realizados no Centro de Caracterização e Desenvolvimento de Materiais - CCDM, no Laboratório de Ensino da Área de Polímeros e no Laboratório de Análises Térmicas do Departamento de Engenharia de Materiais DEMa, da Universidade Federal de São Carlos - UFSCar, e no Laboratório do Departamento de Materiais, Aeronáutica e Automobilística - SMM, da EESC - USP.

Primeiramente, realizou-se o ensaio de identificação de halogênio, para evitar possíveis danos aos equipamentos durante a realização dos ensaios termoanalíticos. Ele foi complementado pelo ensaio termoanalítico DSC, a fim de verificar se havia a presença de possíveis contaminantes, nas amostras de PEAD reciclado. Logo após, foram escolhidas as amostras que mais se afastavam do polietileno de alta densidade puro, com base no grau de cristalinidade, e realizada a análise termogravimétrica (TG), para se ter uma idéia da composição dos materiais reciclados disponíveis no mercado. Para essas amostras, foram determinadas as propriedades mecânicas do PEAD reciclado, por meio dos ensaios de: tração, compressão, flexão estática e impacto.

\section{1- MATERIAIS UTILIZADOS}

Para estudar o polietileno de alta densidade reciclado disponível no mercado, adquiriramse quatro amostras (50 kg de cada) de cores distintas de péletes de PEAD reciclado, provenientes de embalagens moldadas a sopro. Essas amostras foram fornecidas pela Reciclagem Nova Ribeirão, localizada na Rua Americana, 2270, na cidade de Ribeirão Preto, SP, no dia 20/03/2006.

As amostras de cores branca, azul e verde, apresentavam coloração homogênea, enquanto que a vermelha possuía alguns péletes marrons (figura 5.1). Portanto, essa última amostra foi 
dividida em duas, para realizar o ensaio de identificação de halogênio e o ensaio de DSC, a fim de verificar se a diferença era apenas na coloração.

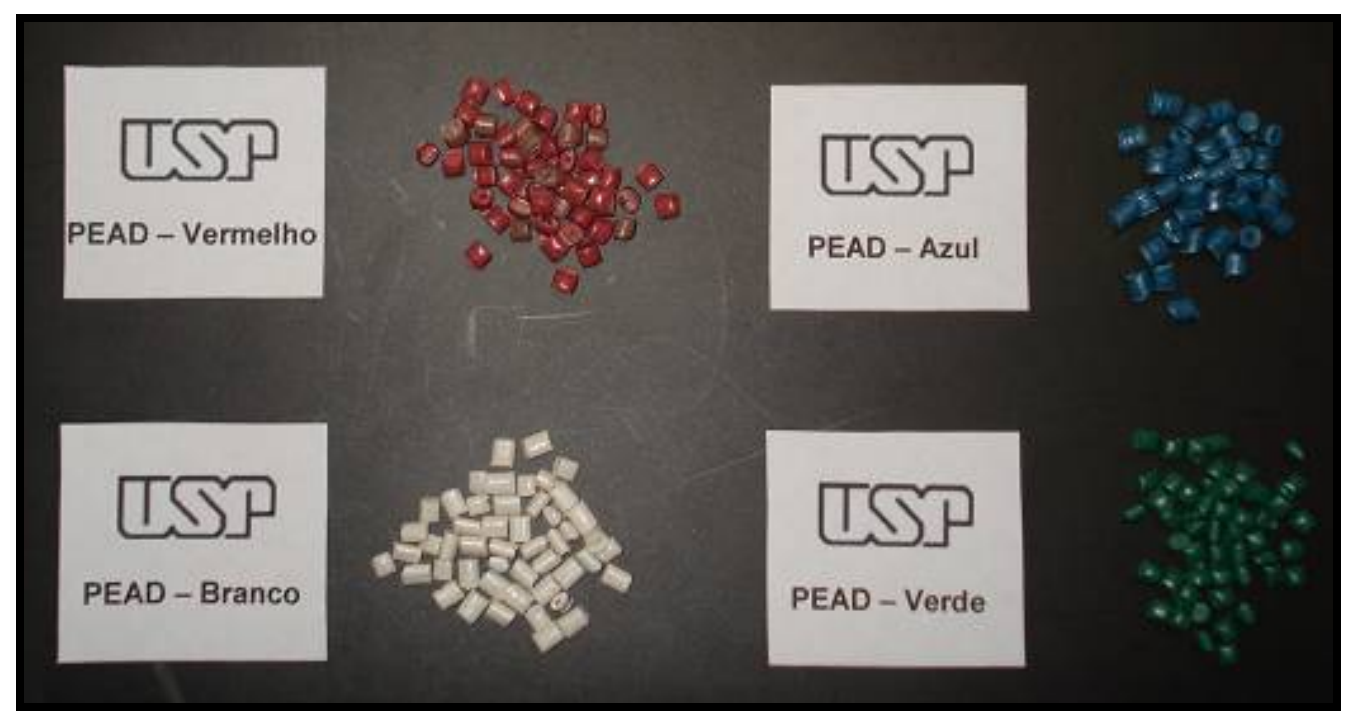

Figura 5.1: Péletes de PEAD: vermelho, azul, branco, verde.

Todas as amostras foram testadas quanto à presença de possíveis contaminantes (Ensaio de Beilstein e Ensaio de DSC). A partir dos resultados desses ensaios, o trabalho teve prosseguimento com as amostras de cores verde e branca.

\section{2- ENSAIO DE BEILSTEIN}

Para a realização do ensaio de Beilstein, foram necessários um fio de cobre e um bico de Bunsen. O ensaio de identificação de halogênio foi realizado no Laboratório de Ensino da Área de Polímeros do DEMa, com acompanhamento do Prof. Dr. José Augusto Marcondes Agnelli. O procedimento deste ensaio está apresentado no anexo A. 


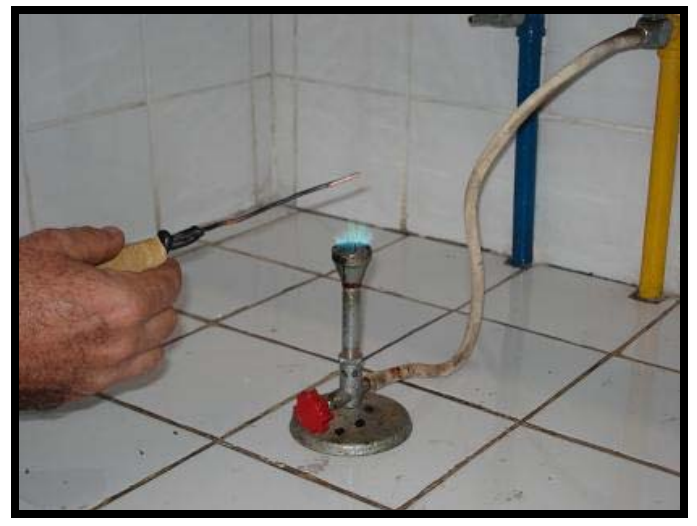

Figura 5.2: Aquecimento do fio de cobre no ensaio de identificação de halogênio.

\section{3- ENSAIOS TERMOANALÍTICOS}

As amostras utilizadas, também chamadas de péletes, foram cortadas com a utilização de lâminas, de modo a ajustar da melhor maneira possível nas cápsulas de ensaio (figura 5.3).

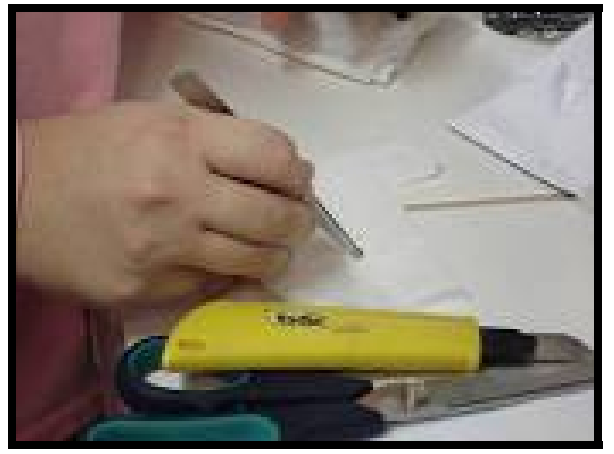

(a)

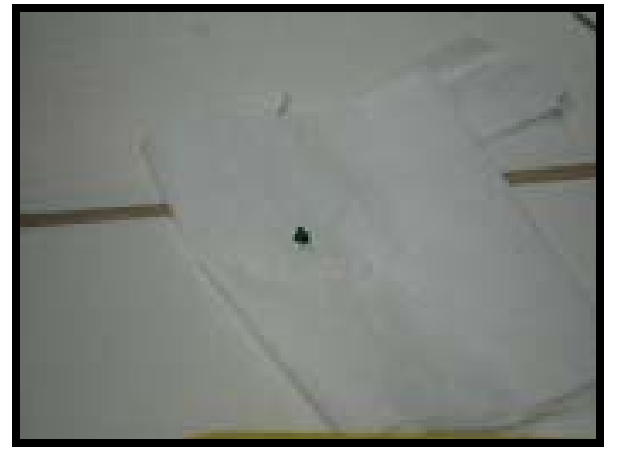

(b)

Figura 5.3: Preparação da amostra: (a) corte do material; (b) PEAD verde utilizado no ensaio de TG.

\subsection{1- Calorimetria Exploratória Diferencial}

Para determinar a temperatura e a entalpia de fusão e de cristalização, foram utilizadas, em conjunto, as seguintes normas da ASTM: D 3417 (99) Standard Test Method for Enthalpies of Fusion and Crystallization of Polymers by Differential Scanning Calorimetry (DSC) e D 3418 (99) Standard Test Method for Transition Temperatures of Polymers by Differential Scanning Calorimetry. 
O ensaio de DSC foi realizado no Laboratório de Análises Térmicas do DEMa, também com o acompanhamento do professor Agnelli. As principais particularidades das normas da ASTM utilizadas neste ensaio estão apresentadas no anexo A.

O equipamento utilizado para realização deste ensaio foi o Perkin-Elmer Modelo DSC 7, com faixa de temperatura de $150^{\circ} \mathrm{C}$, configuração de compensação de potência. Para obter a massa das amostras, bem como a dos cadinhos, utilizou-se uma balança digital marca Mettler Toledo, Modelo AG245 (figura 5.4).

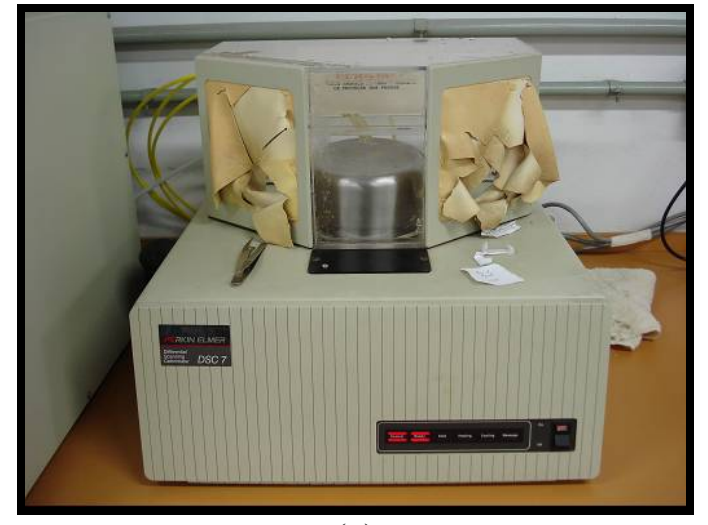

(a)

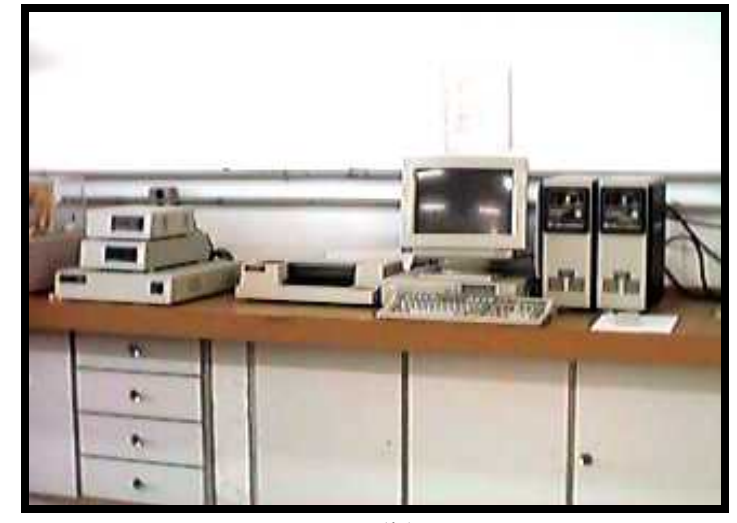

(b)

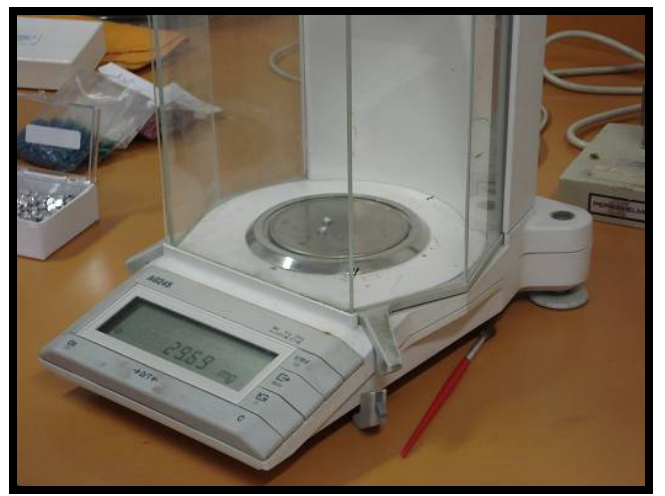

(c)

Figura 5.4: Equipamentos utilizados no ensaio de DSC: (a), (b) calorímetro diferencial de varredura; (c) balança digital.

Foram utilizados dois cadinhos, um contendo o pélete de PEAD e outro vazio, para referência. Ambos tiveram a tampa prensada, para reduzir o gradiente térmico na amostra (figura 5.5). 


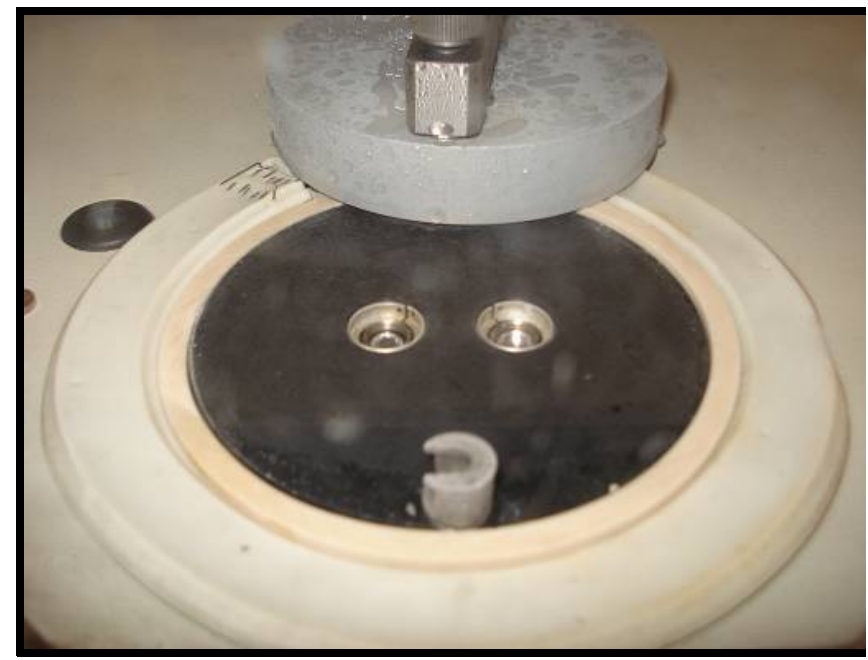

(a)

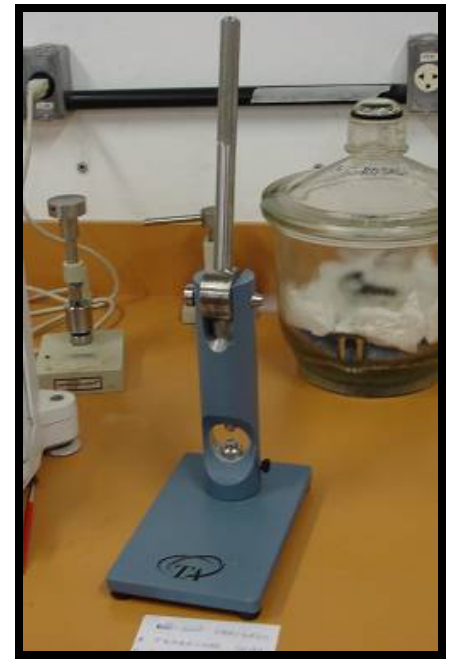

(b)

Figura 5.5: Ensaio de DSC: (a) cadinho de referência e com a amostra no analisador térmico para DSC; (b) Prensador.

Os parâmetros utilizados para realização do ensaio de DSC estão listados na tabela 5.1.

Tabela 5.1: Característica das amostras.

\begin{tabular}{|c|c|c|c|c|c|c|}
\hline \multirow[t]{2}{*}{ Data do ensaio } & \multirow[t]{2}{*}{ Amostra } & \multirow{2}{*}{$\begin{array}{l}\text { Peso da } \\
\text { amostra } \\
\text { (mg) }\end{array}$} & \multirow{2}{*}{$\begin{array}{c}\text { Taxa de } \\
\text { Aquecimento } \\
\left({ }^{\circ} \mathrm{C} / \mathrm{min}\right)\end{array}$} & \multicolumn{2}{|c|}{$\begin{array}{c}\text { Faixa de } \\
\text { Temperatura }\left({ }^{\circ} \mathrm{C}\right)\end{array}$} & \multirow{2}{*}{$\begin{array}{l}\text { Vazão } \\
(\mathrm{N})\end{array}$} \\
\hline & & & & Início & Fim & \\
\hline $19-05-2006$ & Branca & 8,06 & \multirow{5}{*}{10} & \multirow{5}{*}{25} & \multirow{5}{*}{280} & \multirow{5}{*}{15} \\
\hline $18-05-2006$ & Azul & 6,83 & & & & \\
\hline 19-05-2006 & Vermelha & 8,11 & & & & \\
\hline 19-05-2006 & Marrom & 7,55 & & & & \\
\hline 19-05-2006 & Verde & 7,67 & & & & \\
\hline
\end{tabular}

Antes de realizar o ensaio de DSC, o equipamento foi calibrado por meio da determinação da linha base das curvas. Essa curva foi obtida realizando o experimento com as duas cápsulas vazias, com as mesmas condições experimentais do ensaio com as amostras. A linha base ideal é uma reta paralela ao eixo $\mathrm{X}$, ao longo da faixa de temperatura.

Os resultados dos ensaios: temperatura de fusão cristalina $\left(T_{M}\right)$, entalpia de fusão $(\Delta H)$, temperatura no início da fusão $\left(\mathrm{T}_{\text {onset}}\right)$ e grau de cristalinidade $(\chi)$, bem como as curvas de DSC, foram fornecidos por um software acoplado ao calorímetro diferencial de varredura. 


\subsection{2- Termogravimetria}

O ensaio de TG foi realizado no CCDM, sob a responsabilidade do supervisor de laboratório Marcelo A. Chinelatto e do supervisor técnico Rubens E. dos Santos. Algumas particularidades deste ensaio estão apresentadas no anexo A.

As curvas termogravimétrica (TG) e termogravimétrica derivada (DTG) foram obtidas em um módulo termogravimétrico Hi-RES TG 2950 (TA Instruments), acoplado a um analisador térmico TA2000 (TA Instruments). A massa da amostra, antes e durante a realização do ensaio, foi constantemente monitorada por uma termobalança (figura 5.6).

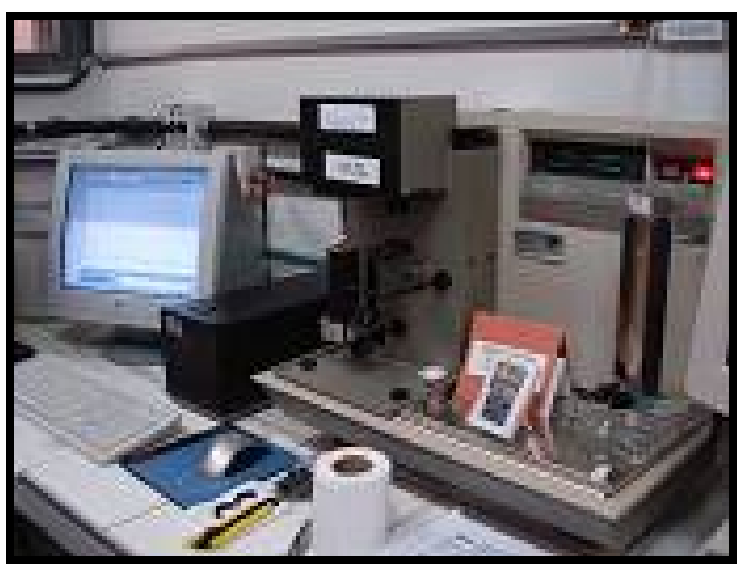

(a)

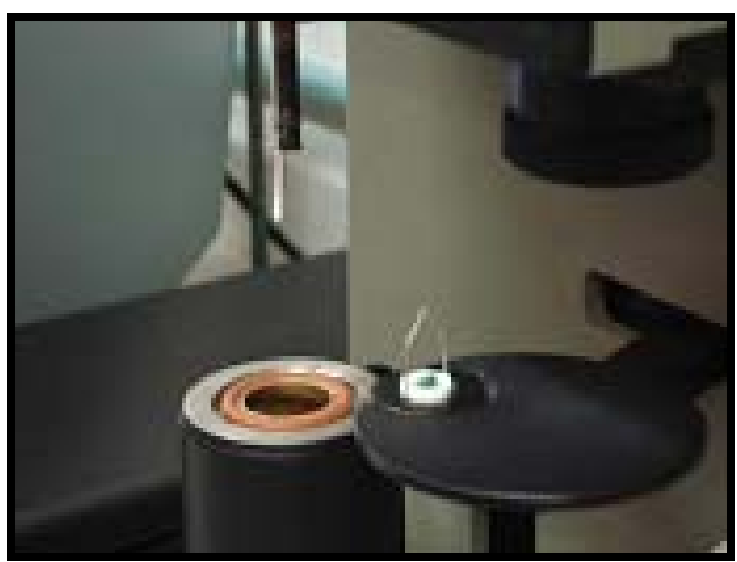

(b)

Figura 5.6: Ensaio de TG: (a) equipamento de TG; (b) pesagem da amostra de PEAD verde antes de realizar o ensaio.

O suporte de amostra utilizado no ensaio de TG foi um cadinho de alumina, por ser um material resistente a altas temperaturas e, portanto, por não reagir com o polímero analisado (figura 5.7). 


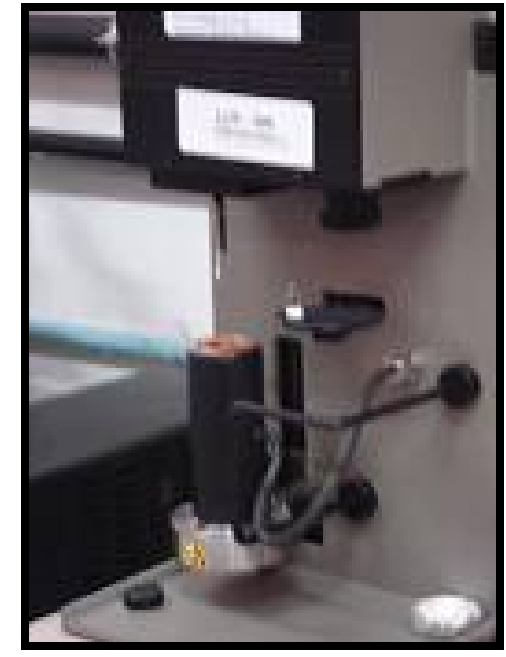

(a)

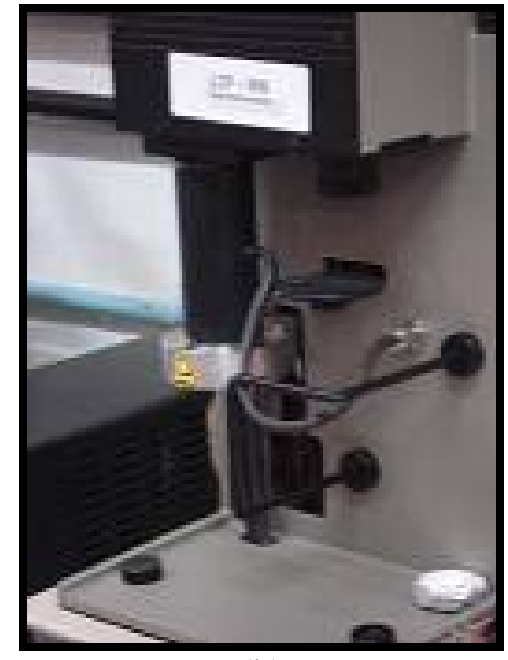

(b)

Figura 5.7: Equipamento de TG: (a) forno aberto; (b) forno fechado.

Os parâmetros utilizados para realização do ensaio de TG estão listados na tabela 5.2.

Tabela 5.2: Característica das amostras verde e branca, ensaio de TG.

\begin{tabular}{|c|c|c|c|c|c|c|}
\hline \multirow[t]{2}{*}{ Data do ensaio } & \multirow[t]{2}{*}{ Amostra } & \multirow{2}{*}{$\begin{array}{c}\text { Peso da } \\
\text { amostra } \\
\text { (mg) }\end{array}$} & \multirow{2}{*}{$\begin{array}{c}\text { Taxa de } \\
\text { Aquecimento } \\
\left({ }^{\circ} \mathrm{C} / \mathrm{min}\right)\end{array}$} & \multicolumn{2}{|c|}{$\begin{array}{c}\text { Faixa de } \\
\text { Temperatura }\left({ }^{\circ} \mathrm{C}\right)\end{array}$} & \multirow{2}{*}{$\begin{array}{c}\text { Vazão } \\
\text { (mL/min) }\end{array}$} \\
\hline & & & & Início & Fim & \\
\hline $07-06-2006$ & Verde & 14,0940 & \multirow{2}{*}{10} & & \multirow{2}{*}{600} & \\
\hline $18-06-2007$ & Branco & 10,9043 & & & & \\
\hline
\end{tabular}

Antes de realizar o ensaio de $\mathrm{TG}$, o equipamento foi calibrado com uma amostra de alumínio, como referência. A calibração do equipamento é feita por meio da temperatura correspondente ao início da fusão ( $\mathrm{T}_{\text {onset }}$ ), que é em torno de $645^{\circ} \mathrm{C}$, e é obtida pela tangente ao pico da temperatura de decomposição da curva DTG.

\section{4- ENSAIOS MECÂNICOS}

Para a fabricação dos corpos-de-prova, foi escolhida a extrusão. Após a extrusão, os corpos-de-prova foram usinados, para obter as dimensões prescritas pelos padrões da ASTM, procedimentos realizados com cuidado para não alterar as propriedades do material em estudo.

Foram realizados os ensaios de tração, de compressão e de flexão, para determinar as propriedades de resistência e rigidez. O ensaio de impacto foi realizado para complementar o 
estudo do material polimérico, pois a resistência ao impacto pelo método Izod não deve ser considerada isoladamente como indicador da resistência mecânica do material, porque muitos polímeros são sensíveis ao entalhe. Os métodos de ensaio, bem como as principais particularidades das normas da ASTM utilizadas neste trabalho, estão apresentados no anexo A.

Entre as amostras de polietileno de alta densidade reciclado, escolheram-se os péletes de coloração verde e branco, para determinar as propriedades de resistência e de rigidez, por meio dos ensaios mecânicos. Conforme foi verificado no ensaio de calorimetria exploratória diferencial, dentre os materiais fornecidos pela recicladora, foram os que apresentaram menor grau de cristalinidade, quando comparados com o pélete virgem.

Os ensaios mecânicos foram realizados em ambiente climatizado com temperatura em torno de $23^{\circ} \mathrm{C}$ e umidade de $50 \%$, seguindo os padrões normativos. Foram ensaiados 10 corposde-prova, para cada tipo de ensaio, tração, compressão, flexão e impacto, e para cada tipo de coloração de pélete: verde e branco.

\subsection{1- Extrusão dos corpos-de-prova}

Existem diversos tipos de processamento de corpos-de-prova: os mais importantes estão descritos por Parente (2006) e por Dalfré (2007). De acordo com Parente (2006), a extrusão é um dos principais processos de conformação dos termoplásticos, pois, além de ser utilizada na produção de produtos acabados e semimanufaturados, ela possui um processo contínuo de alimentação e de produção de elementos perfilados.

Foi utilizada a extrusora monorrosca para termoplásticos reciclados, da empresa IPEX, de São Carlos, SP (figura 5.8). 


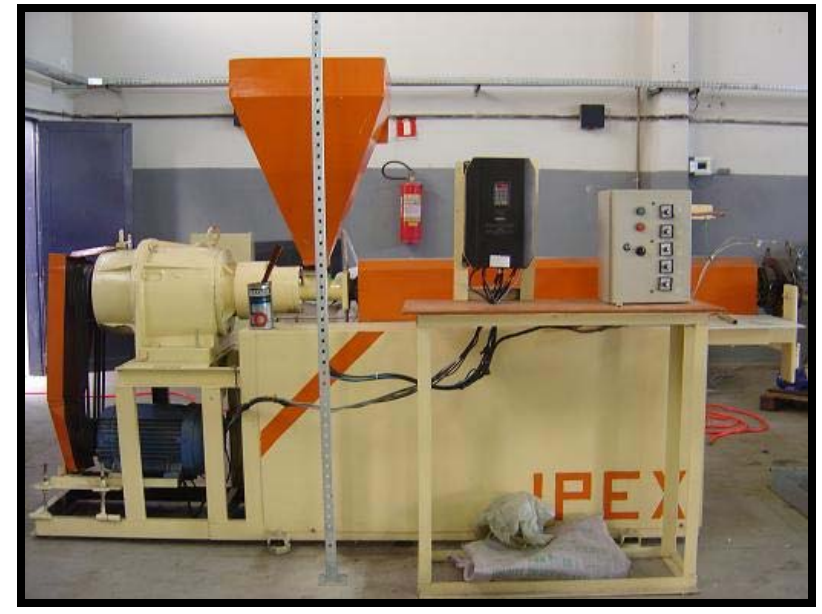

(a)

Silo de alimentação

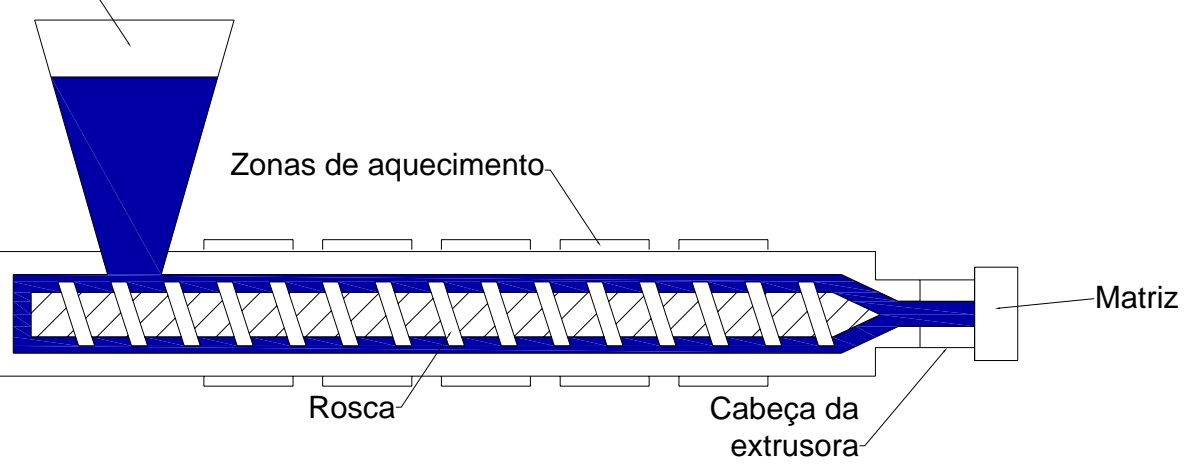

(b)

Figura 5.8: Extrusora monorrosca: (a) foto da extrusora da empresa IPEX;

(b) esquema de uma extrusora monorrosca.

Essa extrusora tem capacidade de produção $120 \mathrm{~kg} / \mathrm{h}$, sendo constituída de:

- $\quad$ Motor de $30 \mathrm{CV}$ com transmissão realizada por polia-correia;

- $\quad$ Inversor de freqüência;

- $\quad$ Painel de controle de temperatura das zonas de aquecimento;

- $\quad$ Silo de alimentação;

- Monorrosca de diâmetro $75 \mathrm{~mm}$ e $4 \mathrm{~m}$ de comprimento, constituída de quatro zonas: transporte, cozimento, plastificação e cabeçote; 
- Canhão composto por cinco zonas de aquecimento, sendo quatro do canhão e uma do cabeçote.

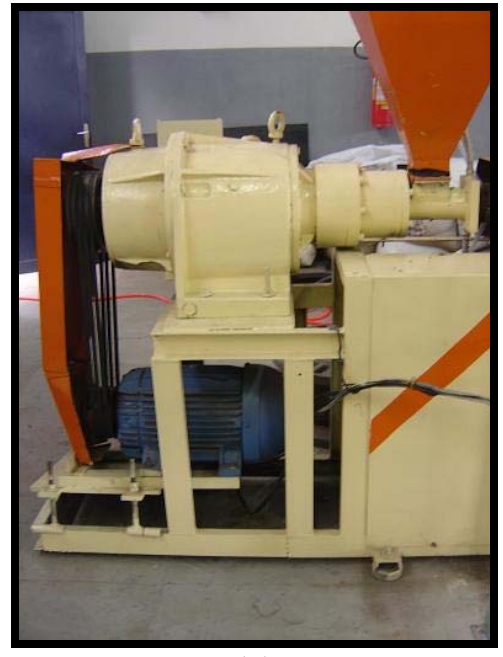

(a)

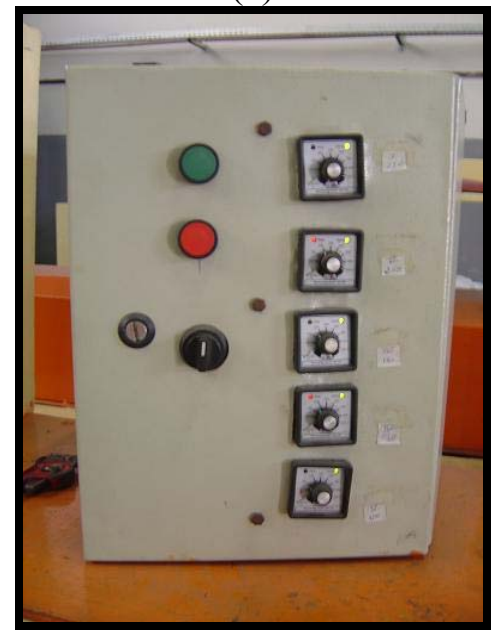

(c)

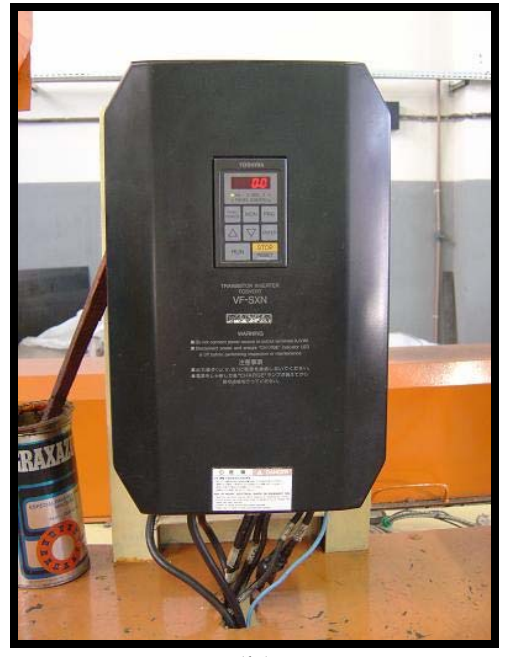

(b)

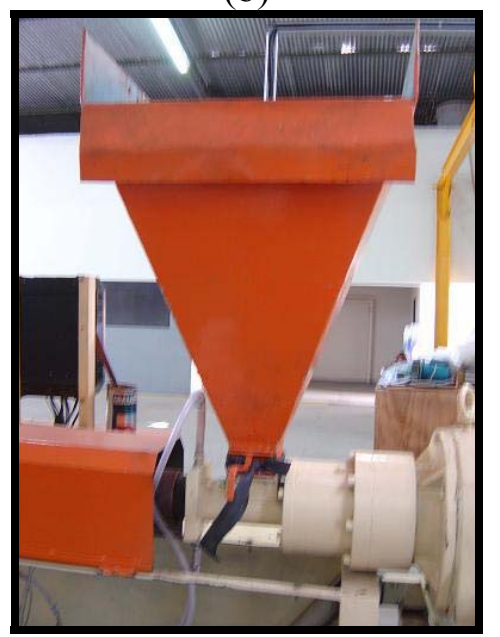

(d)

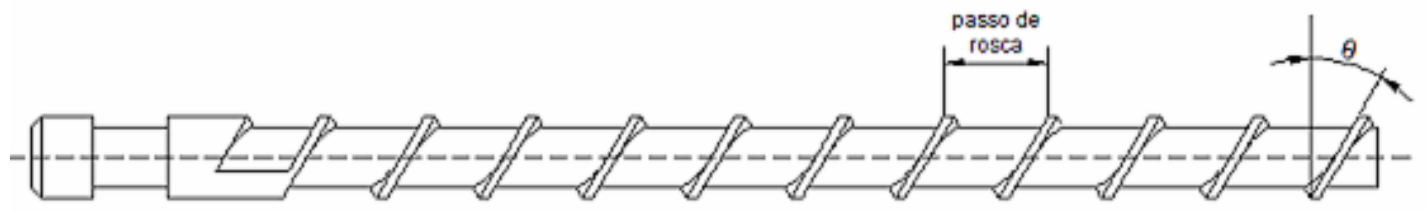

(e)

Figura 5.9: Equipamentos que compõe a extrusora monorrosca: (a) motor com transmissão polia-correia; (b) inversor de freqüência; (c) painel para o controle de temperatura; (d) silo de alimentação; (e) monorrosca. 
A temperatura de extrusão do material polimérico variou entre 150 a $200^{\circ} \mathrm{C}$. Para o processamento dos corpos-de-prova de PEAD, além da extrusora, utilizaram-se os seguintes equipamentos (figura 5.10):

- Articulação para fixação da matriz no canhão, situado na parte externa da monorrosca;

- $\quad$ Matriz de calibração;

- Anel para resfriamento, ligado a um compressor de ar, para criar uma película externa no material extrusado e amenizar o choque térmico ao entrar na banheira de calibração;

- Calibradores para injeção de vácuo e refrigeração interna, acoplados a um chiller, cuja função é refrigerar a água que circula no calibrador;

- Banheira de calibração, constituída de válvula de regulagem para refrigeração da água e vácuo;

- $\quad$ Banheira auxiliar para resfriamento do material polimérico;

- $\quad$ Puxador tipo caterpilar, dotado de correia;

- $\quad$ Serra elétrica automática para corte dos perfis.

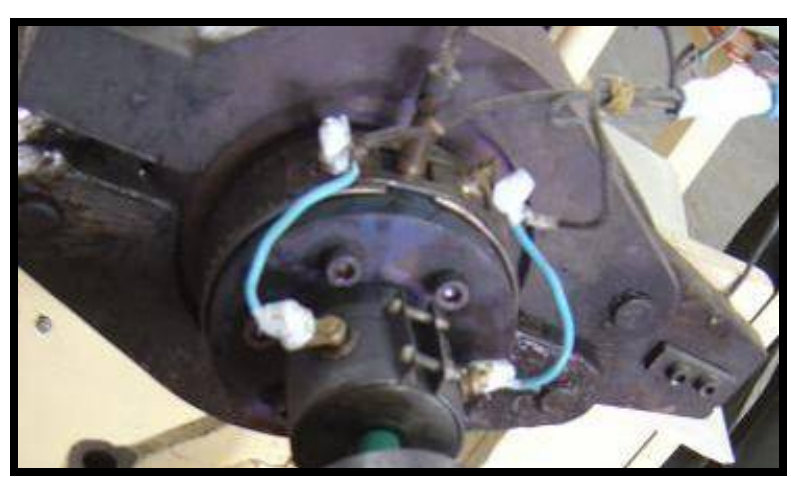

(a)

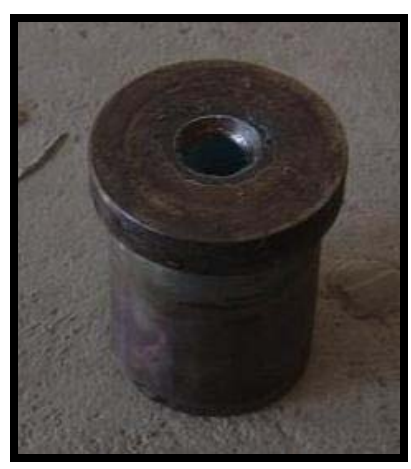

(b) 


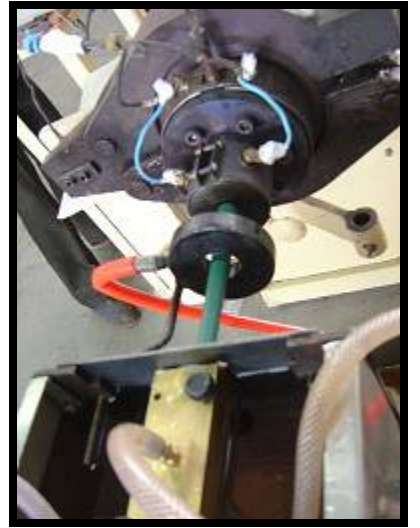

(c)

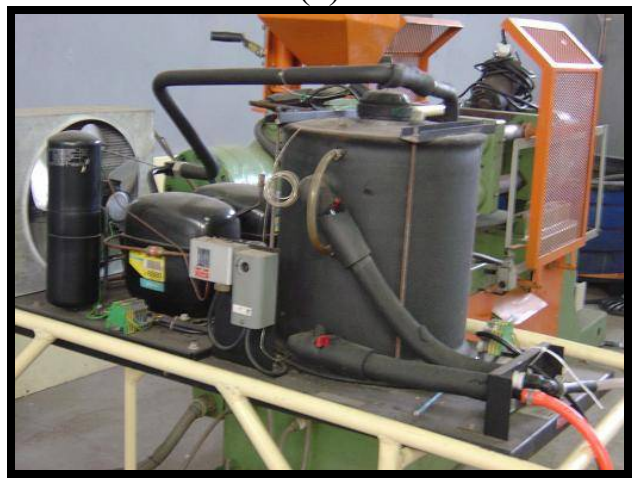

(e)

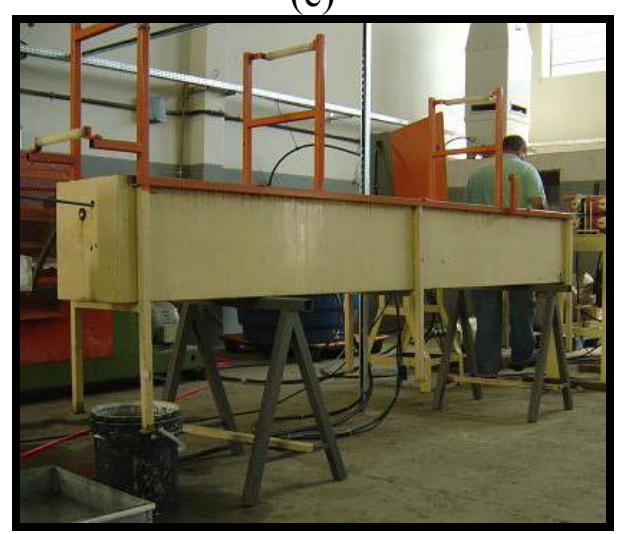

(g)

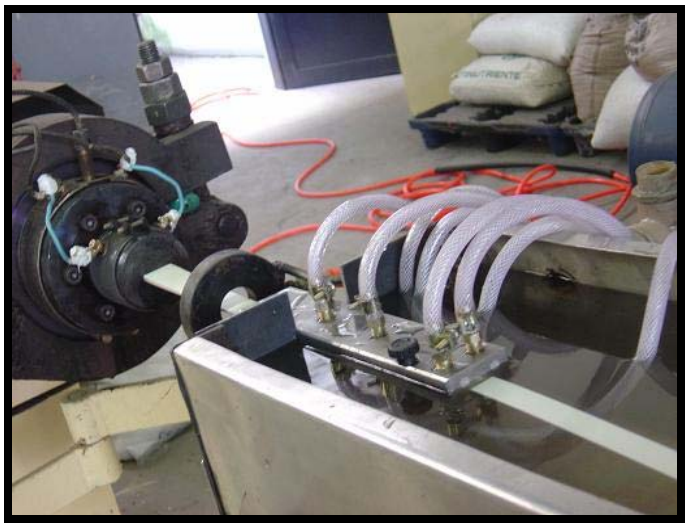

(d)

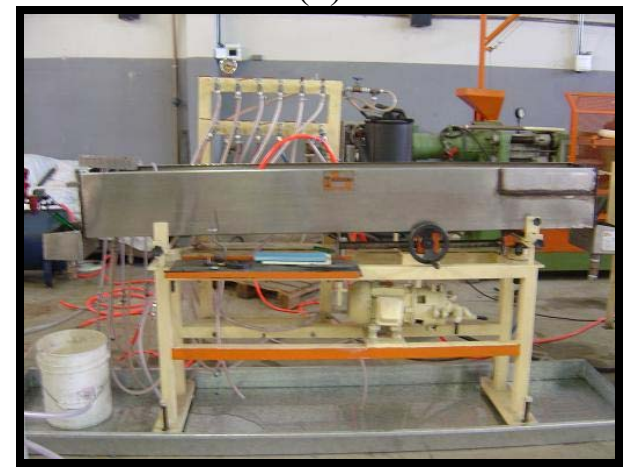

(f)

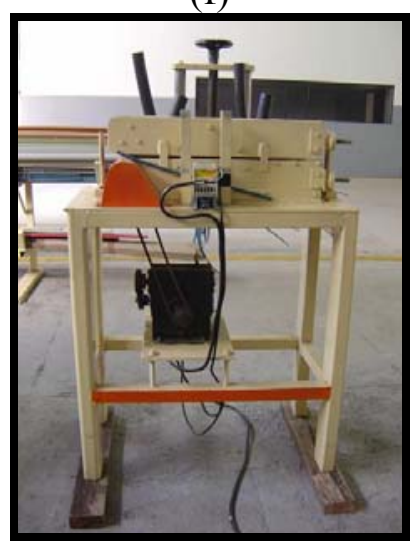

(h) 


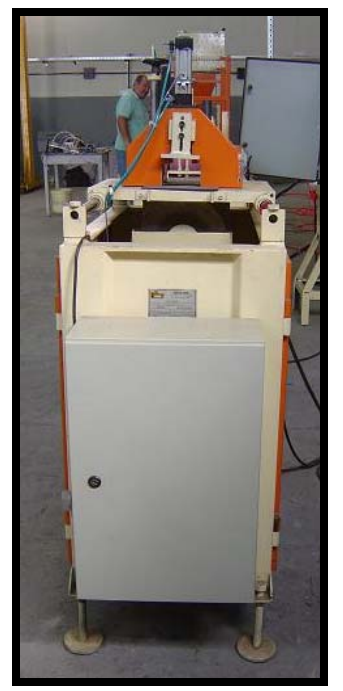

(i)

Figura 5.10: Equipamentos utilizados na moldagem dos corpos-de-prova de tração, de flexão, de compressão e de impacto: (a) articulação para fixação da matriz no canhão; (b) matriz de calibração; (c) anel de ar para resfriamento; (d) calibrador; (e) chiller; (f) banheira de calibração; (g) banheira de resfriamento;

(h) puxador tipo caterpilar; (i) serra elétrica.

Foram confeccionados três matrizes de calibração e três calibradores, devido às dimensões dos corpos-de-prova. Para os corpos-de-prova de tração e de impacto, utilizou-se o mesmo perfil, pois eles possuem a mesma espessura.

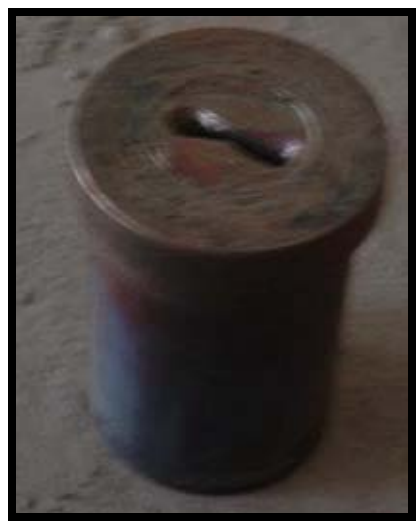

(a)

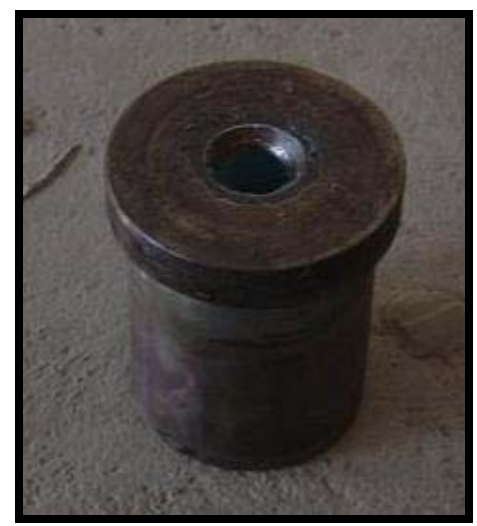

(b) 


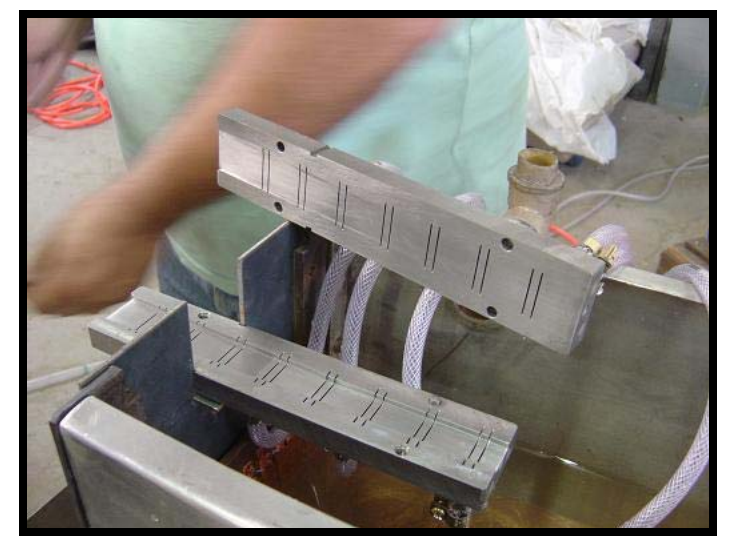

(c)
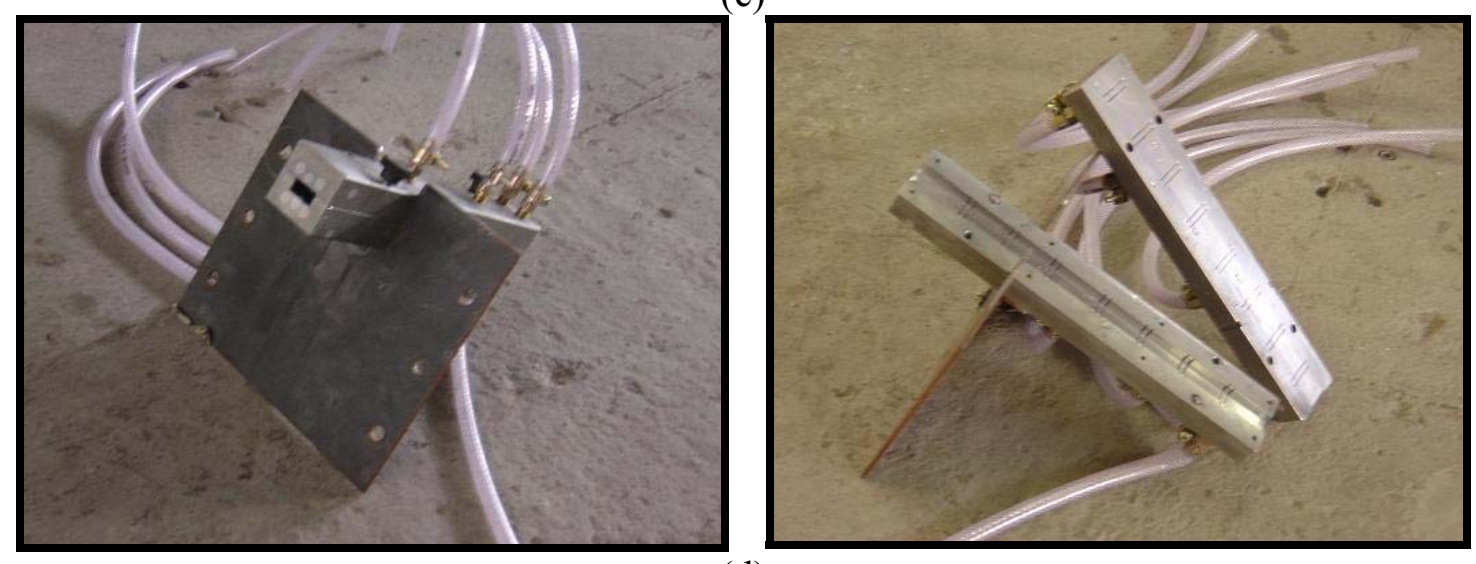

(d)
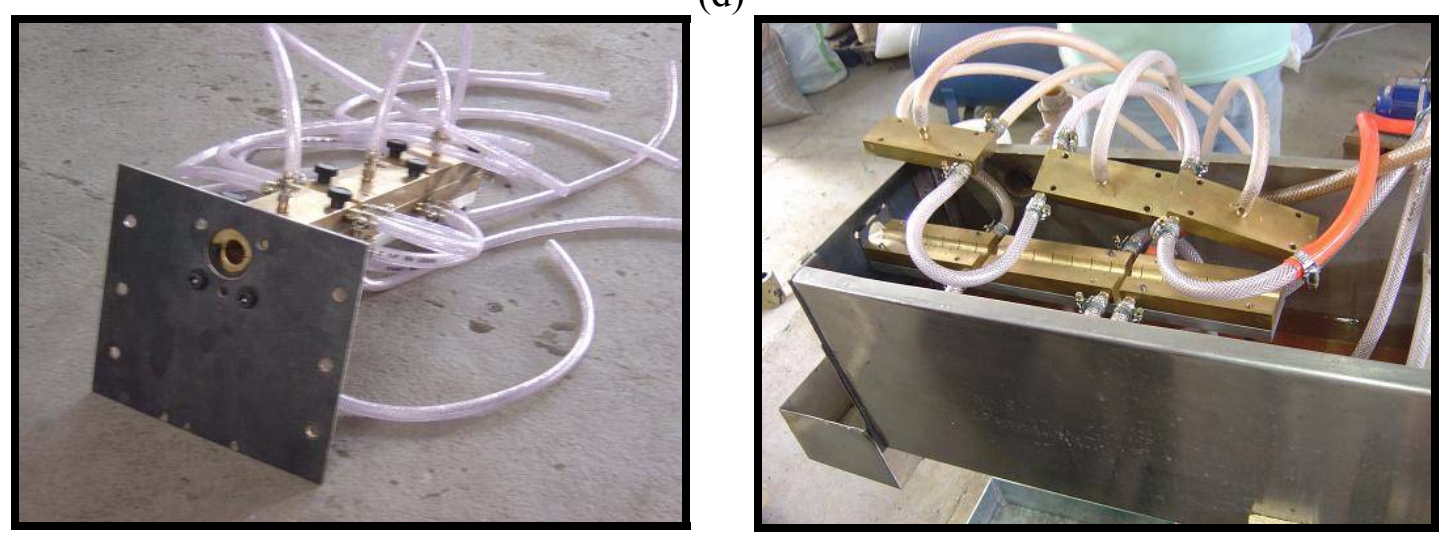

(e)

Figura 5.11: Matrizes e calibradores utilizados na moldagem dos corpos-de-prova: (a) matriz de tração; (b) matriz de compressão; (c) calibrador de tração; (d) calibrador de flexão; (e) calibrador de compressão. 


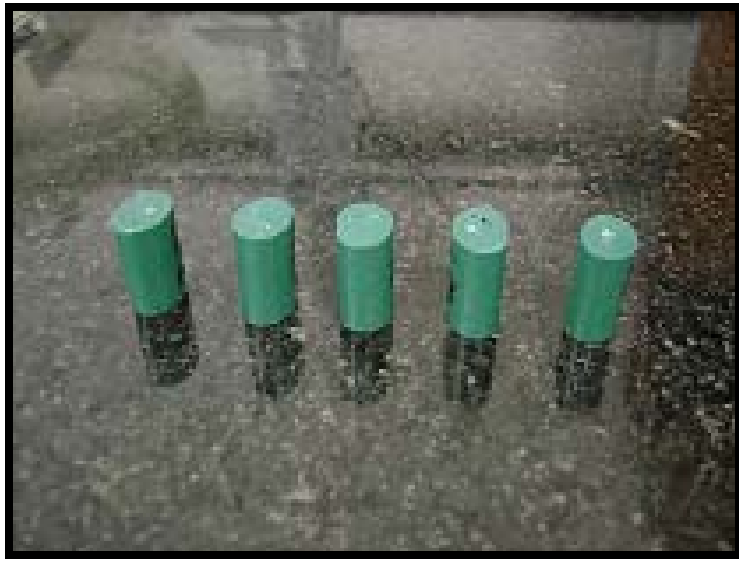

(a)

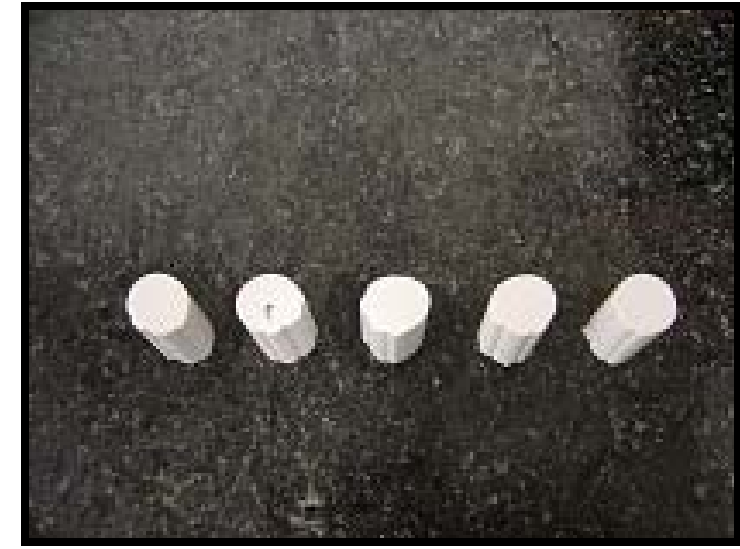

(b)

Figura 5.12: Corpos-de-prova de compressão: (a) verde; (b) branco.

Como mostrado na figura 5.12, os corpos-de-prova obtidos da extrusão apresentaram alguns defeitos como "rechupes" e bolhas. Esses defeitos ocorreram devido às dificuldades encontradas durante a extrusão do PEAD reciclado. Segundo Osorio* (2007), as principais dificuldades encontrada podem ter sido decorrentes de (informação verbal):

- Utilização de polietileno não adequado. Foi empregado PEAD para moldagem a sopro, que é mais apropriado para a extrusão de perfis vazados com paredes finas ou perfis de pequena espessura, como no caso dos corpos-de-prova de tração. O PEAD para sopro tem como característica ser um bom isolante térmico, ou seja, seu processo de resfriamento é muito lento. Portanto, durante a extrusão, a cristalização não é uniforme, pois ele se resfria apenas externamente e, por estar mole internamente, ocorre a formação de "rechupes", apresentando superfície externa irregular no final do processo. O material mais utilizado em extrusão é o PVC que, por ser um material com maior rigidez, resfria-se mais rápido, proporcionando melhores resultados no processamento. Existe um polietileno mais adequado para extrusão, que apresenta maior plasticidade quando aquecido e não rompe durante a calibração, como ocorreu com os corpos-de-prova cilíndricos, que apresentavam maior seção transversal, entre os corpos-de-prova confeccionados;

\footnotetext{
* Informação fornecida por Luciano Souza Osorio, em São Carlos, em 2007.
} 
- A porosidade apresentada nas faces cortadas dos corpos-de-prova pode ser proveniente de umidade; provavelmente, este aspecto poderia ser melhorado aquecendo o material no aglutinador, antes de ser colocado no silo de alimentação;

- $\quad$ A rosca utilizada não possui características propícias ao material empregado. Deveria possuir diâmetro menor, em torno de $30 \mathrm{~mm}$, para se conseguir maior velocidade, já que a produção de material é inversamente proporcional à relação $\mathrm{D} / \mathrm{L}$ (diâmetro/comprimento da rosca), isto é, quanto maior for $\mathrm{D}$, menor será a produção de material. $\mathrm{O}$ aumento da produção corresponde a um menor tempo de material no canhão, aquecendo menos e resfriando mais rápido, ao entrar no sistema de resfriamento;

- $\quad$ Outra característica da rosca que dificultou a extrusão do polietileno foi o diâmetro interno constante, isto é, a taxa de compressão utilizada foi de 1 para 1. O ideal seria possuir taxa de compressão de 3,5 para 1, ou seja, entrariam três volumes e meio e sairia apenas um, pois a altura do filete diminuiria ao longo do comprimento da rosca. Nesse caso, haveria maior compactação do material, diminuindo-se a porosidade, já que os gases gerados no aquecimento voltariam à entrada da extrusora, evitando a formação de bolhas.

Portanto, com material e equipamento apropriado, além de diminuir a porosidade, poderia ser utilizada menor temperatura durante o processamento dos corpos-de-prova, resfriando mais rápido e evitando a ocorrência de bolhas e "rechupes", obtendo também maior produção.

\subsection{2- Usinagem dos corpos-de-prova}

O equipamento utilizado para a usinagem do estreitamento da parte central do corpo-deprova de tração foi a Frezadora Universal AZERF ASA/79 1. O bitz, material cortante utilizado na usinagem, possuía comprimento de $76 \mathrm{~mm}$, raio desejado para o estreitamento do corpo-deprova de tração. 


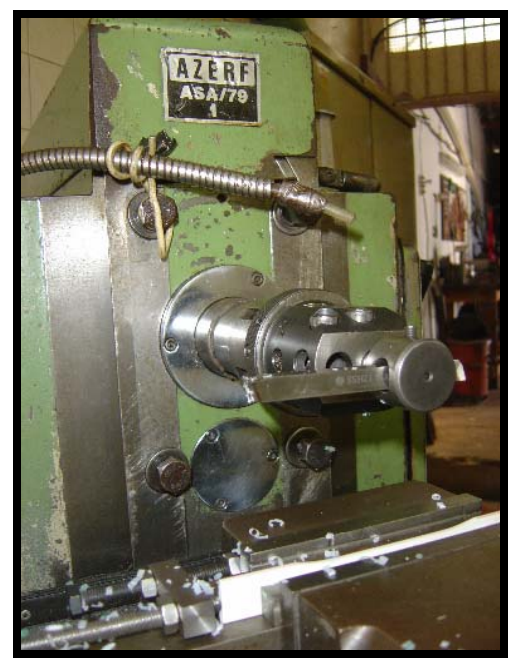

(a)

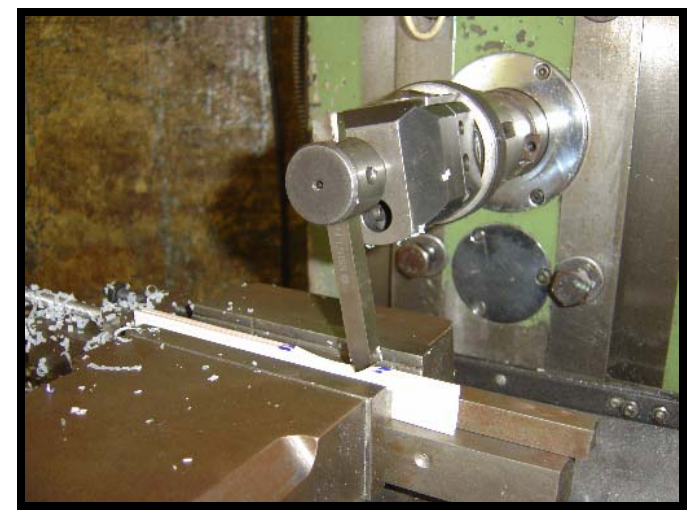

(b)

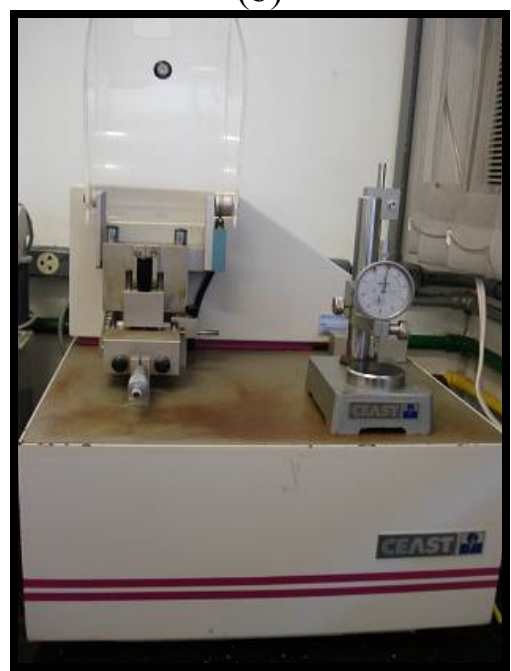

(d)

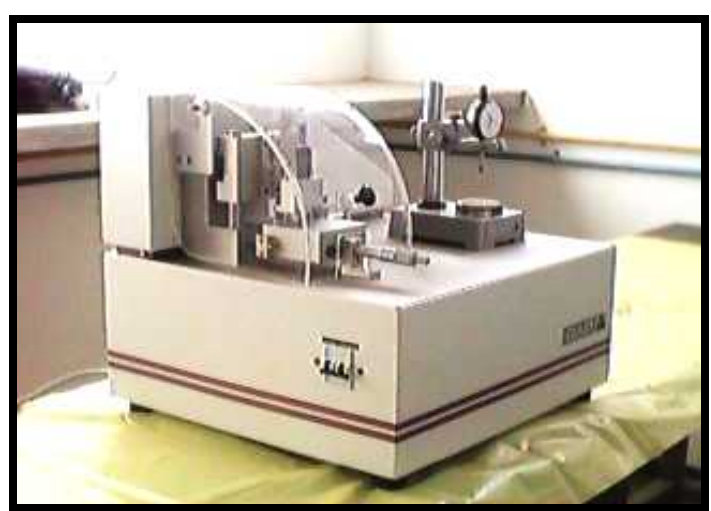

(c)

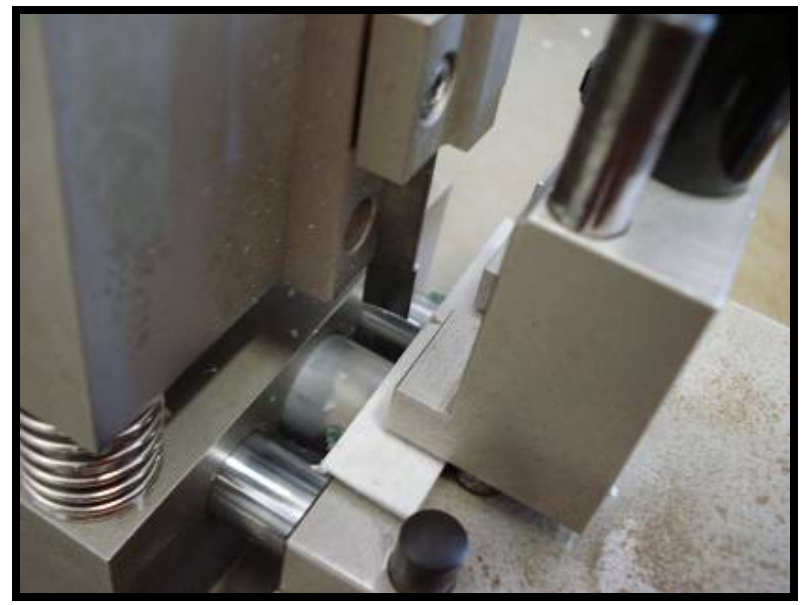

(e)

Figura 5.13: Usinagem dos corpos-de-prova: (a) frezadora Universal AZERF ASA/79 1; (b) usinagem do corpo-de-prova de tração; (c), (d) fresa entalhadora para usinagem dos corpos-de-prova de impacto;

(e) execução do entalhe no corpo-de-prova. 
Os corpos-de-prova de flexão foram cortados com tesoura e aparados na mesma Frezadora Universal AZERF ASA/79 1. Já os corpos-de-prova de compressão foram cortados em torno.

Os corpos-de-prova de impacto foram obtidos a partir dos corpos-de-prova de tração, reduzindo a largura com a mesma frezadora. Para a execução do entalhe, utilizou-se a fresa entalhadora para usinagem de corpos-de-prova de impacto do tipo Izod/Charpy, marca CEAST, modelo Notchvis. A entalhadora é motorizada, com entalhes padronizados segundo a norma ASTM D 256-04.

Houve uma pequena variação nas dimensões dos corpos-de-prova, principalmente nos corpos-de-prova cilíndricos, pois a sua maior seção transversal necessitava de maior comprimento para seu calibrador, aumentando, assim, o tempo para o resfriamento dos corposde-prova. Essa variação poderia ser amenizada usinando-os lateralmente. Porém, devido à porosidade apresentada na superfície do corte, descartou-se esta opção, pois, mesmo usinados, não se conseguiria homogeneidade.

\subsection{3- Ensaio de Tração}

O ensaio de tração foi realizado de acordo com o procedimento da ASTM D 638 (03) Standard Test Method for Tensile Properties of Plastics. As dimensões do corpo-de-prova, como mostrado na figura 5.14, estão de acordo com o tipo I.
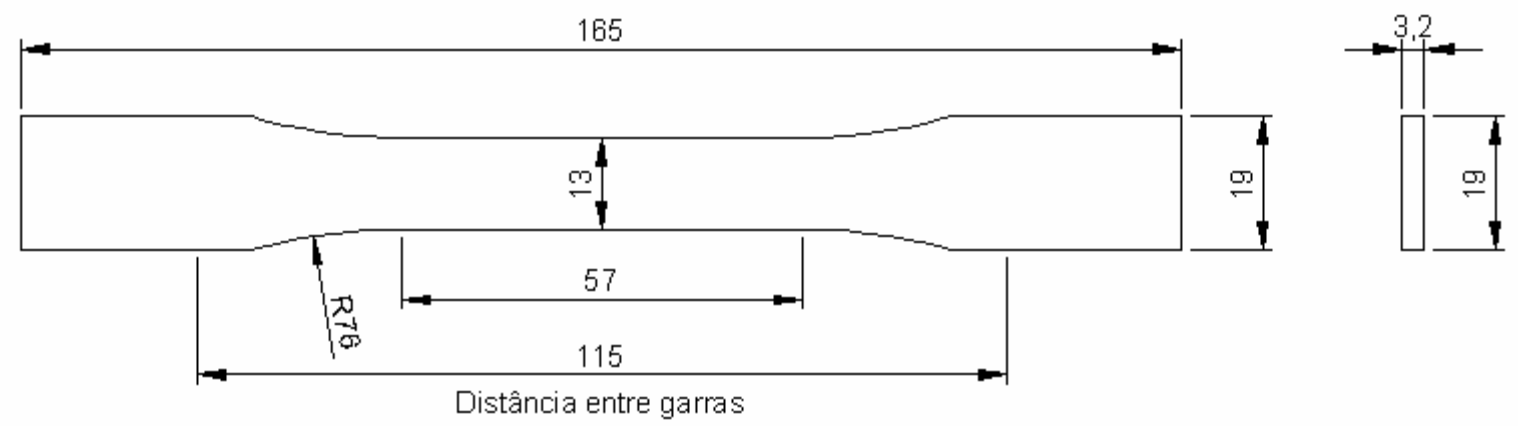

Figura 5.14: Corpo-de-prova tipo I (dimensões em mm). Fonte: ASTM D 638 -03. 
Os ensaios de tração nos corpos-de-prova de PEAD foram realizados no dia 01 de junho de 2007, no Laboratório do Núcleo de Ensaios de Materiais e Análise de Falhas (NEMAT), do Departamento de Engenharia de Materiais (SMM), da EESC. O ensaio foi realizado pelo técnico João Bernard e acompanhado pelo pós doutorando Cassius Ruckert. O equipamento utilizado foi a máquina de ensaio universal EMICTM, modelo DL 10000, com célula de carga com capacidade de $1000 \mathrm{~N}$ interligada ao software Tesc - versão 1.13, que registrava valores de deslocamento e de força.

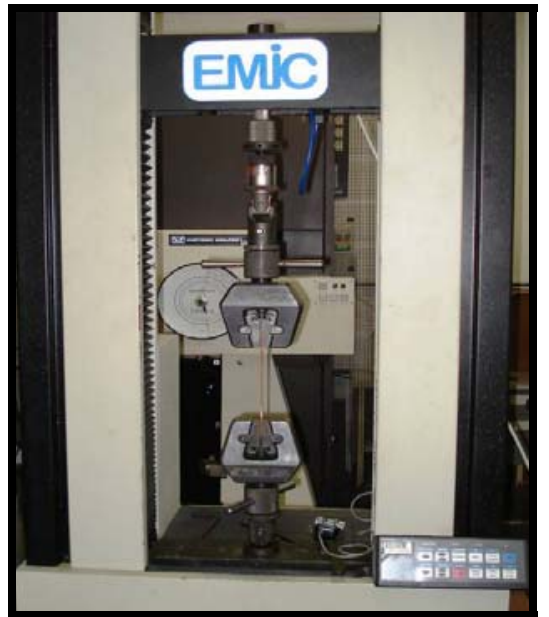

(a)

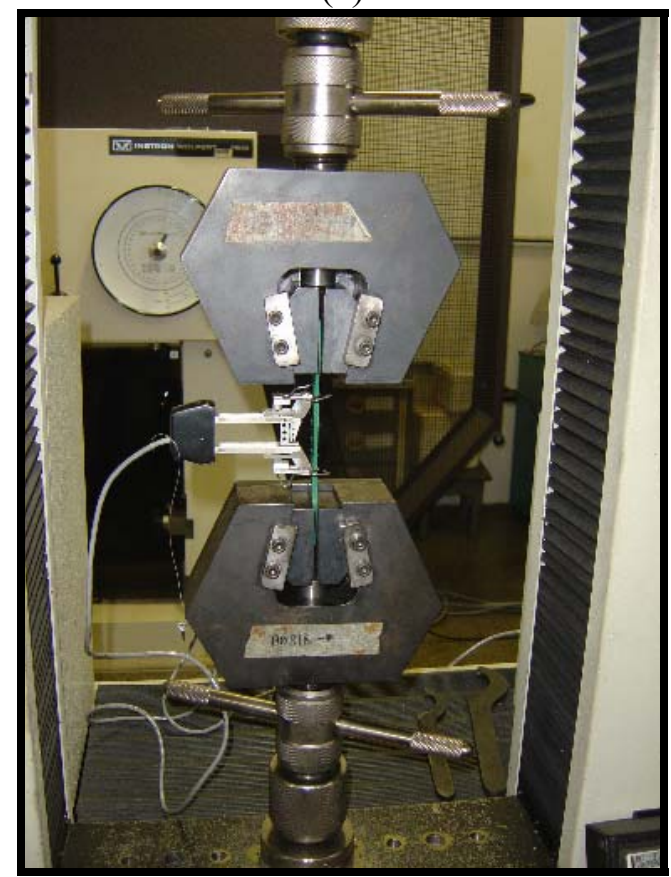

(c)

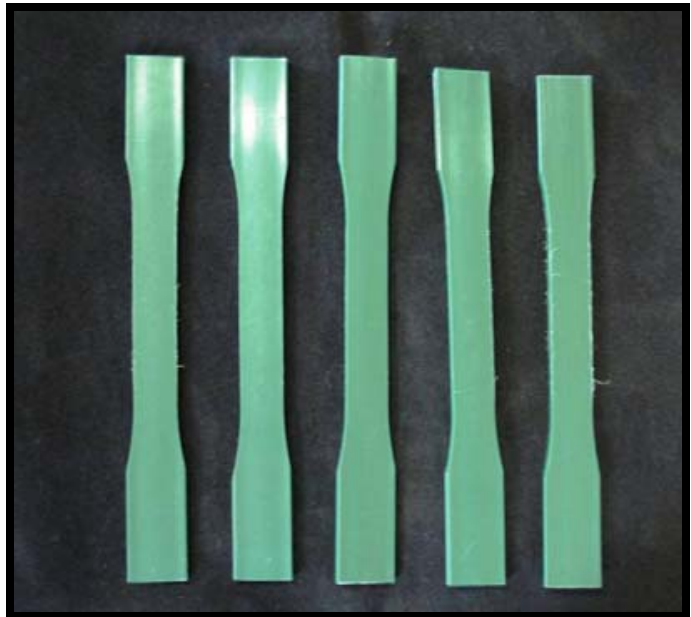

(b)

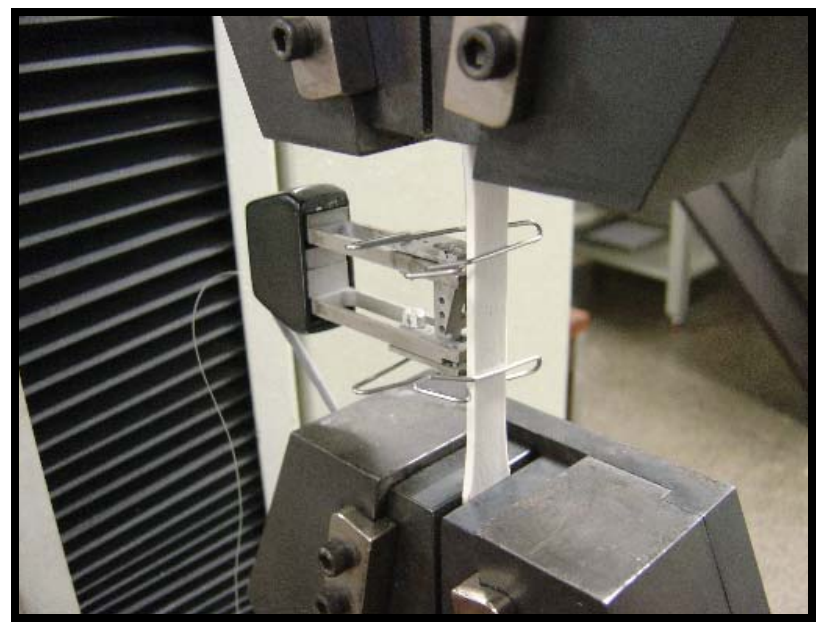

(d) 


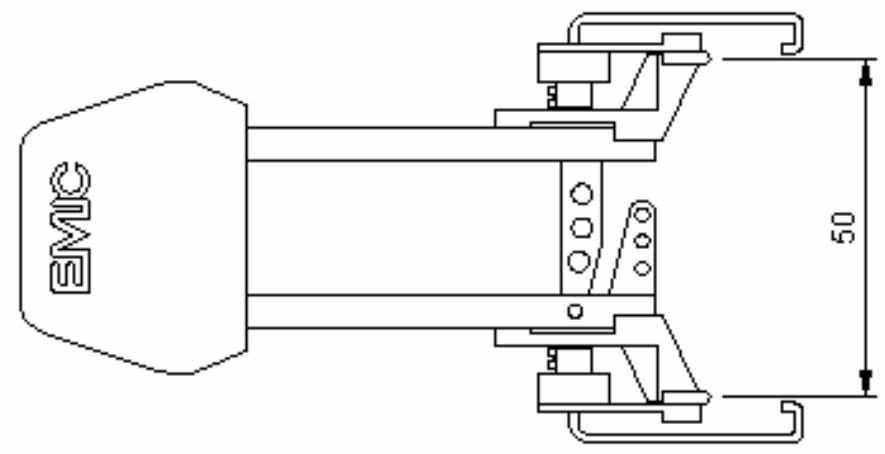

(e)

Figura 5.15: Ensaio dos corpos-de-prova de tração: (a) máquina de ensaio universal EMICTM adaptada com garras para o ensaio de tração; (b) corpos-de-prova verdes tipo I; (c) corpo-de-prova verde posicionado na máquina; (d) detalhe do extensômetro no corpo-de-prova branco; (e) extensômetro montado com prolongadores para comprimento base de 50mm - Fonte: EMIC Equipamentos e Sistemas de Ensaio Ltda,. Manual EEPA.

Metade dos corpos-de-prova (cinco fabricados com o pélete verde e cinco com o branco) foram ensaiados com velocidade de deslocamento de $5 \mathrm{~mm} / \mathrm{min}$, apenas para medir o módulo de elasticidade. O deslocamento foi quantificado por meio de um extensômetro eletrônico EMIC, modelo EEPA, com base de medida de 50mm, posicionado na região central do corpo-de-prova. $\mathrm{O}$ resultado obtido corresponde à tensão e à deformação nos pontos $0,05 \%$ e $0,25 \%$ de deformação, segundo a ISO 527-1.

Os demais corpos-de-prova foram submetidos a uma velocidade de deslocamento de $50 \mathrm{~mm} / \mathrm{min}$ para determinação da tensão e da deformação no escoamento, tensão e deformação na ruptura e elongação percentual. O deslocamento foi obtido com a utilização de um transdutor indutivo de deslocamento, acoplado á máquina. $\mathrm{O}$ ensaio foi conduzido dessa maneira, pois a ASTM D 638 - 03 exige que o módulo seja obtido à velocidade de $5 \mathrm{~mm} / \mathrm{min}$, já para os demais parâmetros não há essa exigência, e sim que a duração dos ensaios esteja entre $1 / 2$ e 5 minutos.

\subsection{4- Ensaio de Compressão}

O ensaio de compressão foi realizado de acordo com o procedimento da ASTM D 695 2(a) Standard Test Method for Compressive Properties of Rigid Plastics. O corpo-de-prova utilizado no ensaio de compressão possuia seção cilíndrica, com altura equivalente ao dobro do diâmetro (figura 5.16). 


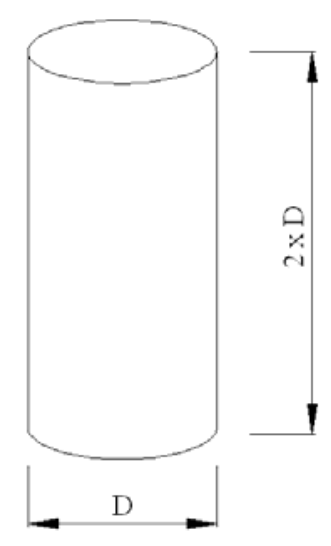

Figura 5.16: Corpos-de-prova submetidos à compressão.

O ensaio de compressão foi realizado no dia 04 de junho de 2007, no Laboratório do Núcleo de Ensaios de Materiais e Análise de Falhas (NEMAT) do Departamento de Engenharia de Materiais (SMM) da EESC. O ensaio foi realizado pelo técnico João Bernard e acompanhado pelo pós doutorando Cassius Ruckert. $\mathrm{O}$ equipamento utilizado foi à máquina de ensaio universal EMICTM, modelo DL 10000, com célula de carga com capacidade de $1000 \mathrm{~N}$ interligada ao software Tesc - versão 1.13, que registrava valores de deslocamento e de força.

Todos os corpos-de-prova de PEAD, dez de coloração verde e dez de coloração branca, foram submetidos a uma velocidade de deslocamento de $1,3 \mathrm{~mm} / \mathrm{min}$. Os deslocamentos foram obtidos com a utilização de um transdutor de deslocamento acoplado à máquina de ensaio universal EMICTM.

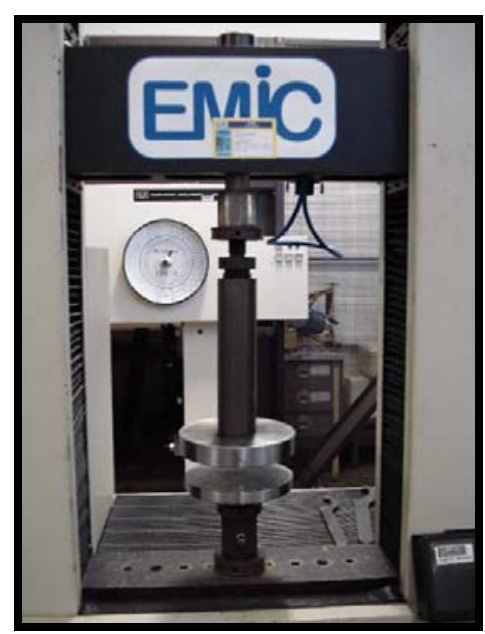

(a)

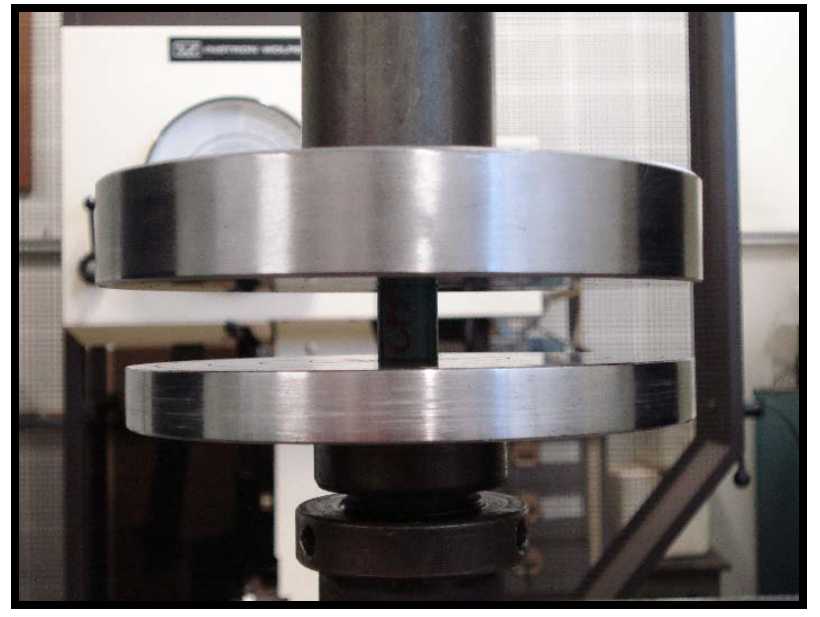

(b) 


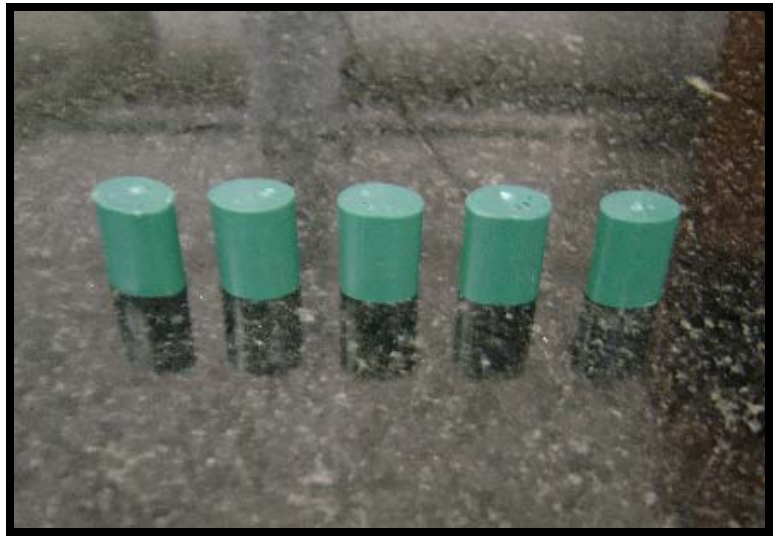

(c)

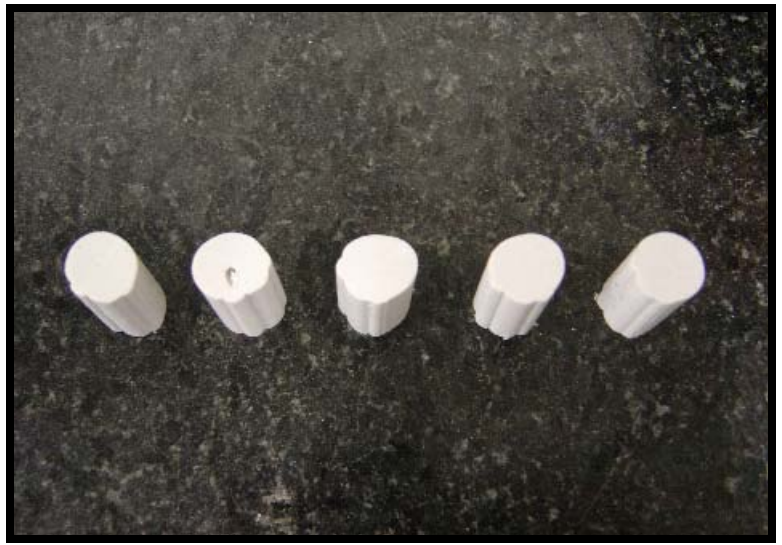

(d)

Figura 5.17: Ensaio dos corpos-de-prova de compressão: (a) máquina de ensaio universal EMICTM, com garras para o ensaio de compressão; (b) corpo-de-prova verde posicionado na máquina;

(c) corpos-de-prova verdes; (d) corpos-de-prova brancos.

Devido às dificuldades encontradas durante o processo de moldagem, obtiveram-se corpos-de-prova de compressão com seções transversais diferentes das dimensões prescritas pela ASTM D 695 2(a), 12,7mm de diâmetro. Por esse motivo, utilizou-se um estéreo microscópio Carlzeiss, modelo Citoval II, acoplado a um aquisitor digital de imagem, para obter as seções transversais dos corpos-de-prova, que foram quantificadas com a utilização de um software de analisador de imagem digital, Image Pró Pluss - versão 4.5.

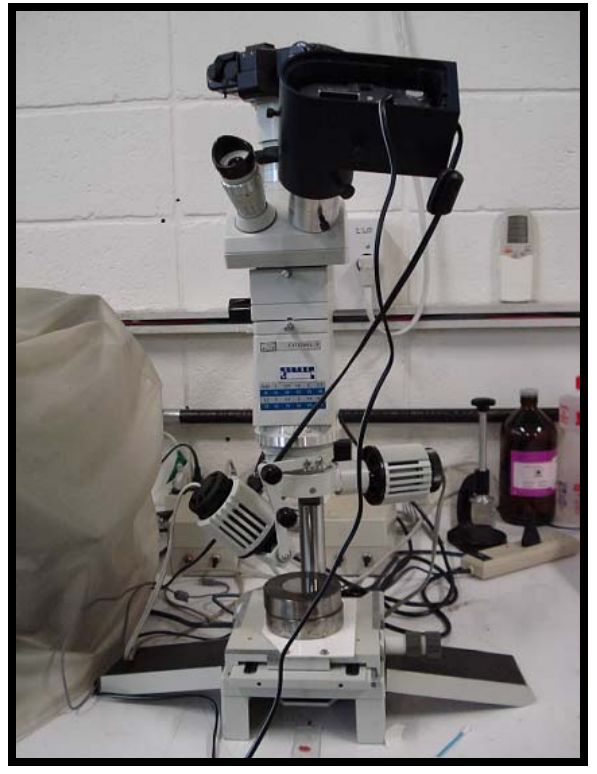

(a)

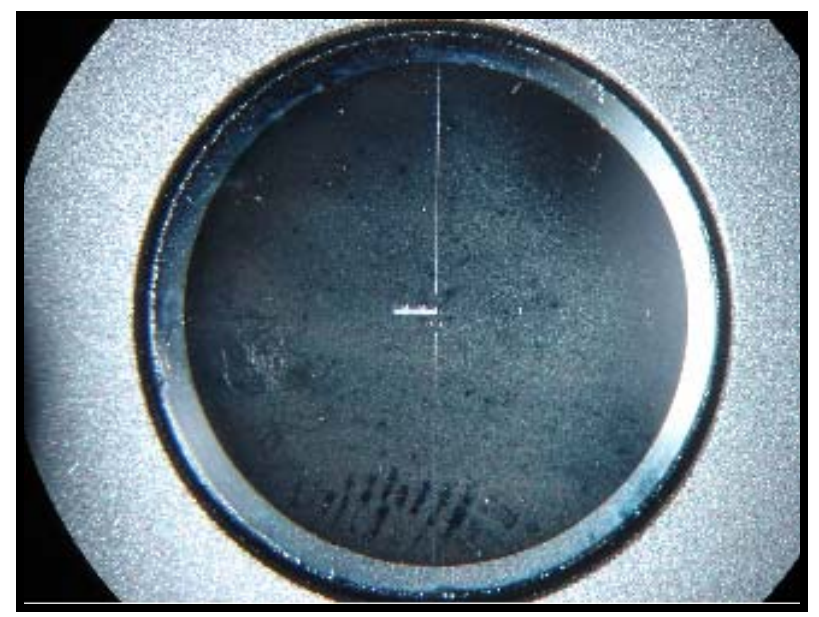

(b) 


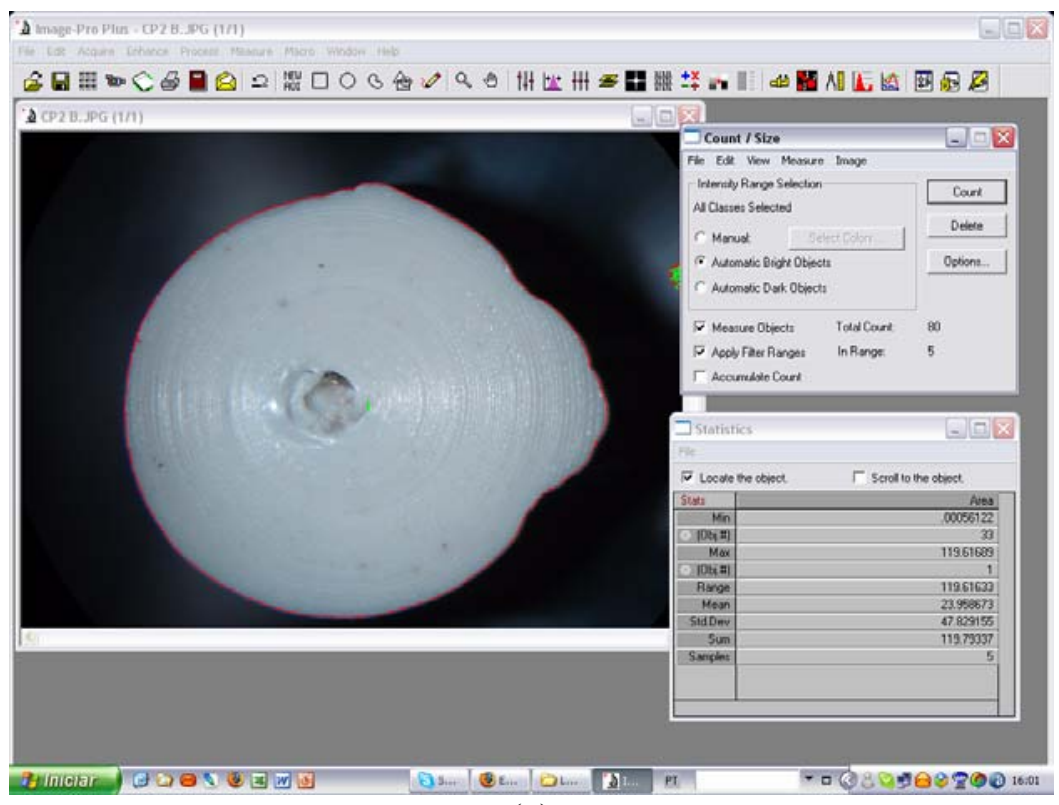

(c)

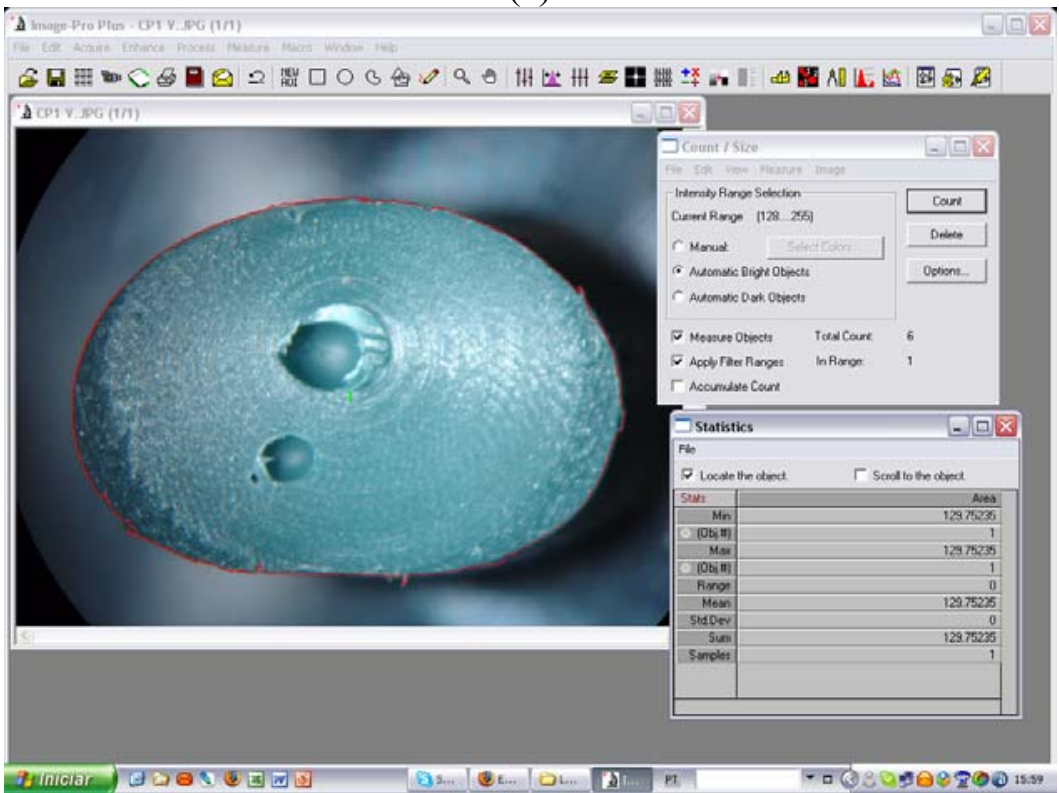

(d)

Figura 5.18: Obtenção de imagem dos corpos-de-prova de compressão: (a) estérilmicroscópio Carlzeiss ; (b) calibrador utilizado; (c) medição da área do corpo-de-prova branco; (d) medição da área do corpo-de-prova verde.

\subsection{5- Ensaio de Flexão}

O ensaio de flexão foi realizado de acordo com o procedimento da ASTM D 790 (03) Standard Test Method for Flexural Properties of Unreinforced and Reinforced Plastics and Electrical Insulating Materials. 
Para a realização deste ensaio, adotou-se o procedimento A, pois é o método utilizado quando se deseja obter propriedades de flexão, mesmo prevendo que o material suportaria grandes deslocamentos durante o ensaio, situação em que é mais indicado o procedimento B.

De acordo com a tabela 3 da ASTM D 790 (03), foram definidos os seguintes parâmetros para o corpo-de-prova de flexão.

Tabela 5.3: Característica dos corpos-de-prova de flexão.

\begin{tabular}{ccccc}
\hline & \multicolumn{4}{c}{ L/d = 16 } \\
\cline { 2 - 5 } $\begin{array}{c}\text { Profundidade } \\
\mathbf{6 , 4} \mathbf{~ m m}\end{array}$ & $\begin{array}{c}\text { Largura } \\
(\mathbf{m m})\end{array}$ & $\begin{array}{c}\text { Comprimento } \\
(\mathbf{m m})\end{array}$ & $\begin{array}{c}\text { Distância } \\
\text { entre apoios } \\
(\mathbf{m m})\end{array}$ & $\begin{array}{c}\text { Vão da carga } \\
(\mathbf{m m})\end{array}$ \\
\cline { 2 - 5 } & 12,7 & 127 & 102 & 51 \\
\hline
\end{tabular}
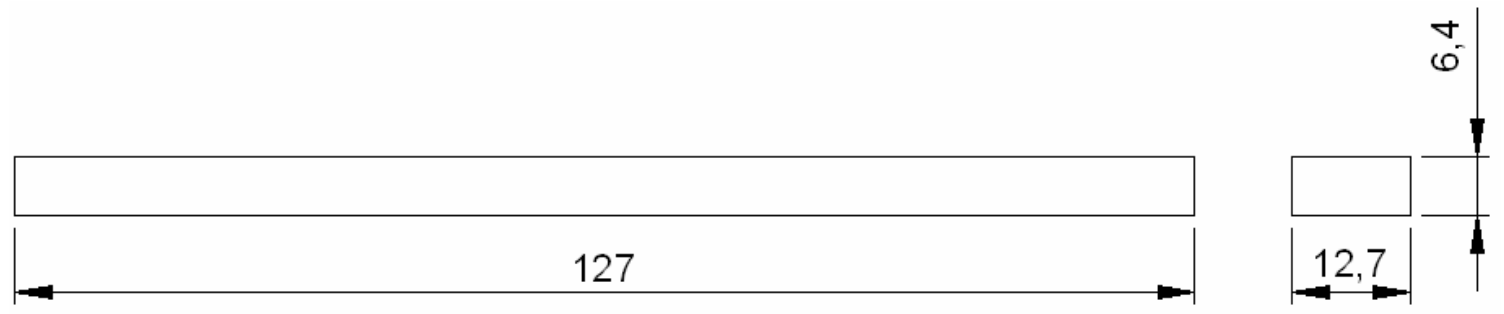

Figura 5.19: Corpo-de-prova mais usual para o ensaio de flexão (dimensões em mm).

Fonte: ASTM D 790 - 03

A velocidade de ensaio e o deslocamento máximo, para todos os corpos-de-prova de PEAD, figura 5.19, dez de coloração verde e dez de coloração branca, foi $2,8 \mathrm{~mm} / \mathrm{min}$ e $13,55 \mathrm{~mm}$ respectivamente. Esses parâmetros foram obtidos por meio das equações A.3 e A.4, admitindo a deformação máxima permitida de $5 \%$, e a taxa de deformação de $0,01 \mathrm{~mm} / \mathrm{mm} / \mathrm{min}$, na superfície oposta ao carregamento.

O ensaio de flexão foi realizado no dia 04 de junho de 2007, no Laboratório do Núcleo de Ensaios de Materiais e Análise de Falhas (NEMAT) do Departamento de Engenharia de Materiais (SMM) da EESC. O ensaio foi realizado pelo técnico João Bernard e acompanhado pelo pós doutorando Cassius Ruckert. O raio das superfícies em contato com o corpo-de-prova foi de $3,42 \mathrm{~mm}$, dentro do limite permitido pela norma referida. $\mathrm{O}$ equipamento utilizado foi à máquina 
de ensaio universal EMICTM, modelo DL 10000, com célula de carga com capacidade de $1000 \mathrm{~N}$ interligada ao software Tesc - versão 1.13, que registrava valores de deslocamento e de força.

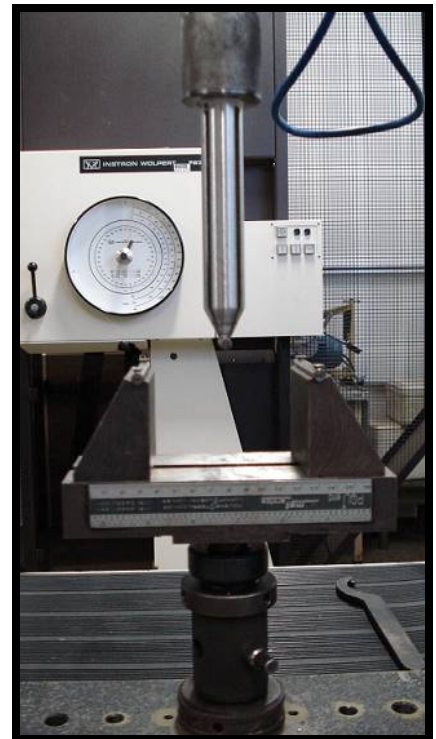

(a)

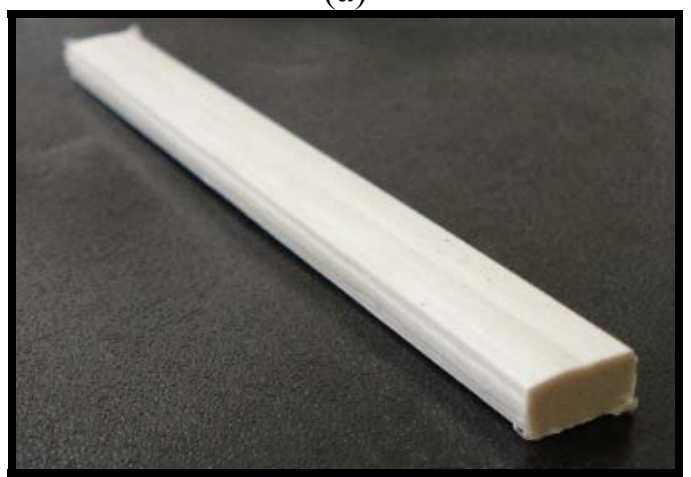

(c)

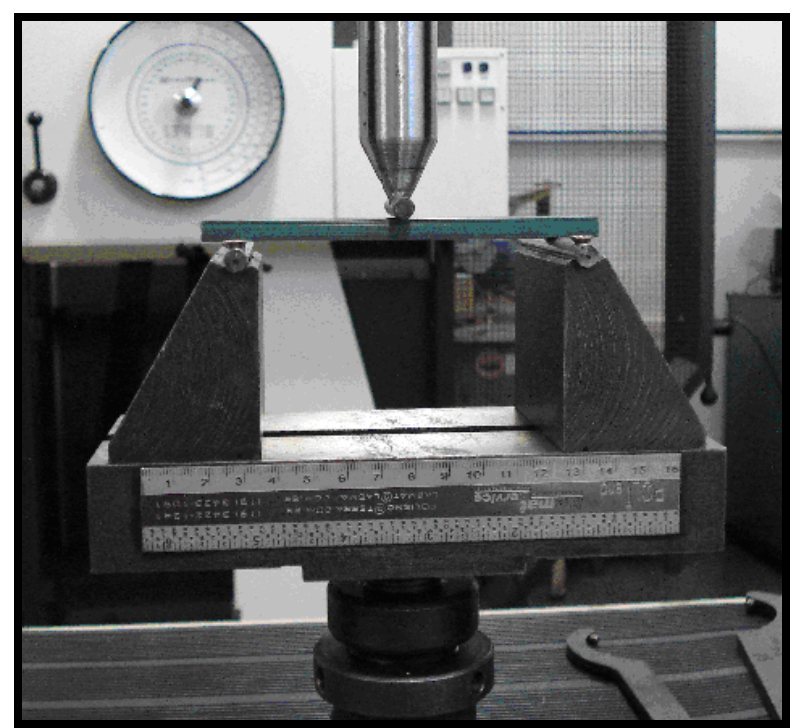

(b)

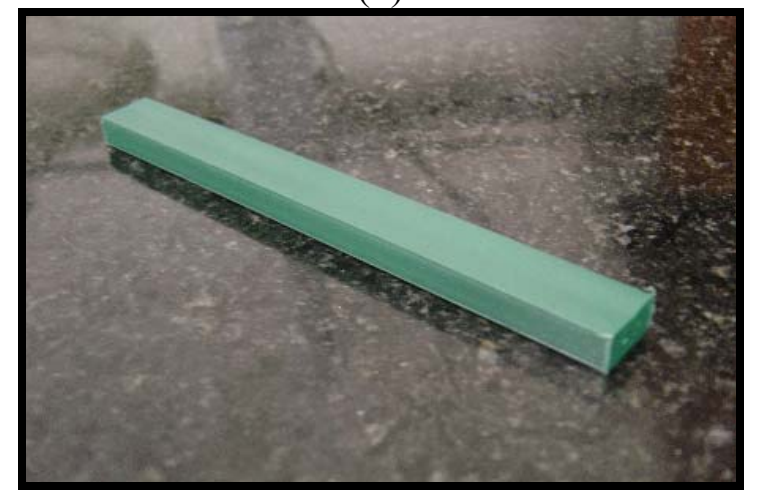

(d)

Figura 5.20: Ensaio dos corpos-de-prova de flexão: (a) máquina de ensaio universal EMICTM com garras para o ensaio de compressão; (b) corpo-de-prova verde posicionado na máquina; (c) corpos-de-prova verdes; (d) corpos-de-prova brancos.

O deslocamento máximo foi obtido com a utilização de um transdutor de deslocamento, acoplado à máquina de ensaio universal EMIC ${ }^{\mathrm{TM}}$.

\subsection{6- Ensaio de Impacto}

O ensaio de impacto Izod foi realizado de acordo com o procedimento da ASTM D 25604 Standard Test Method for Determining the Izod Pendulum Impact Resistence of Plastics, que 
se refere aos corpos-de-prova providos de entalhe. A energia de ruptura dos polímeros ao impacto pode ser quantificada em termos de joule por metro $(\mathrm{J} / \mathrm{m})$ e/ou kilojoule por metro quadrado $\left(\mathrm{J} / \mathrm{m}^{2}\right)$. Este método de ensaio tem um título similar ao da norma ISO 180:1993, porém o conteúdo é bastante diferente.

Escolheu-se a espessura de 3,2mm, por ser bastante utilizada, segundo os padrões normativos (Canevarolo, 2000). O entalhe foi usinado no lado menor, pois sua dimensão é menor do que 12,5mm (anexo A). Devido aos corpos-de-prova terem largura inferior a 6,35 $\mathrm{mm}$, foram tomados cuidados especiais para evitar uma flexão lateral durante o ensaio.

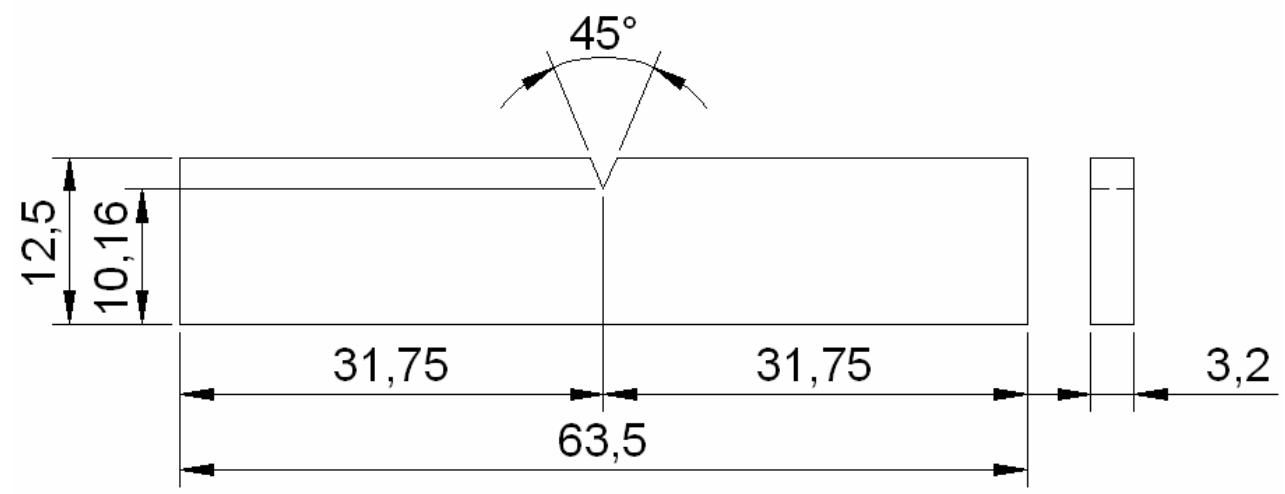

Figura 5.21: Corpo-de-prova provido de entalhe (dimensões em mm). Fonte: ASTM D 256 - 04

Após 24 horas da execução do entalhe, tempo de condicionamento, foram realizados os ensaios de Impacto Izod nos corpos-de-prova de PEAD, no dia 05 de julho de 2007, no Laboratório de Ensino da Área de Polímeros do DEMa. A usinagem do entalhe e o ensaio de impacto foram acompanhados pelo professor Agnelli. O equipamento utilizado foi a máquina de impacto instrumentada, marca CEAST, modelo RESIL 25R, provida de um martelo que liberou uma energia de $2 \mathrm{~J}$. A perda de energia do pêndulo por atrito corresponde a $0,024 \mathrm{~J}$. O método de ensaio escolhido foi o tipo A da norma consultada (anexo A). 


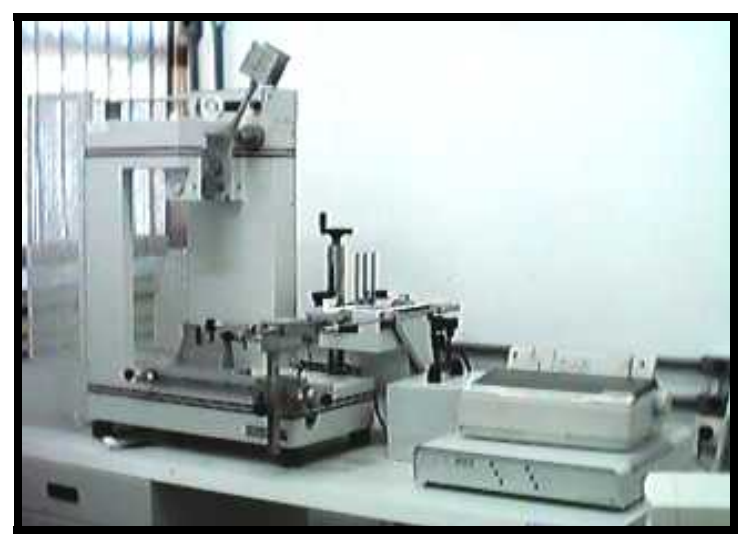

(a)

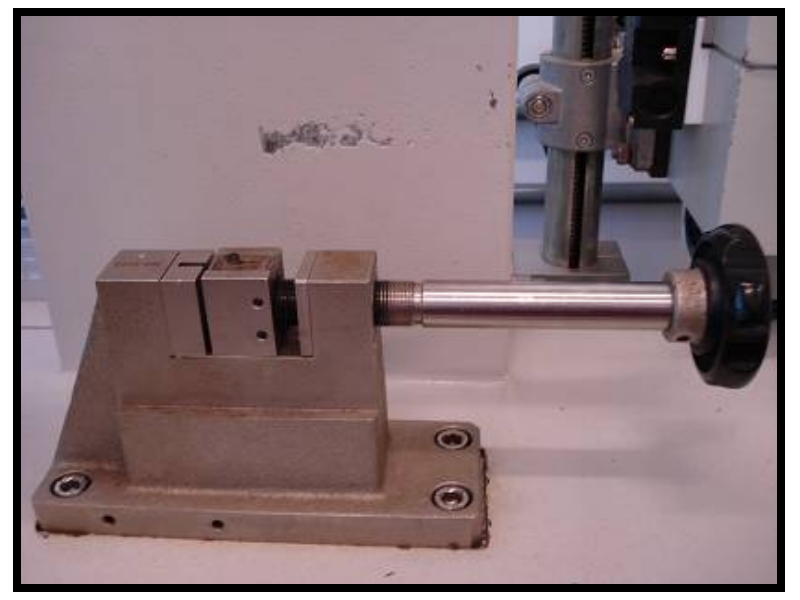

(c)

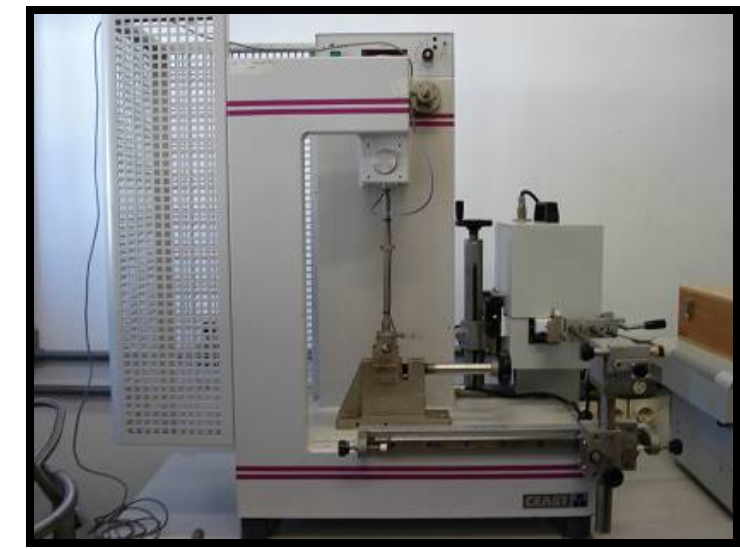

(b)

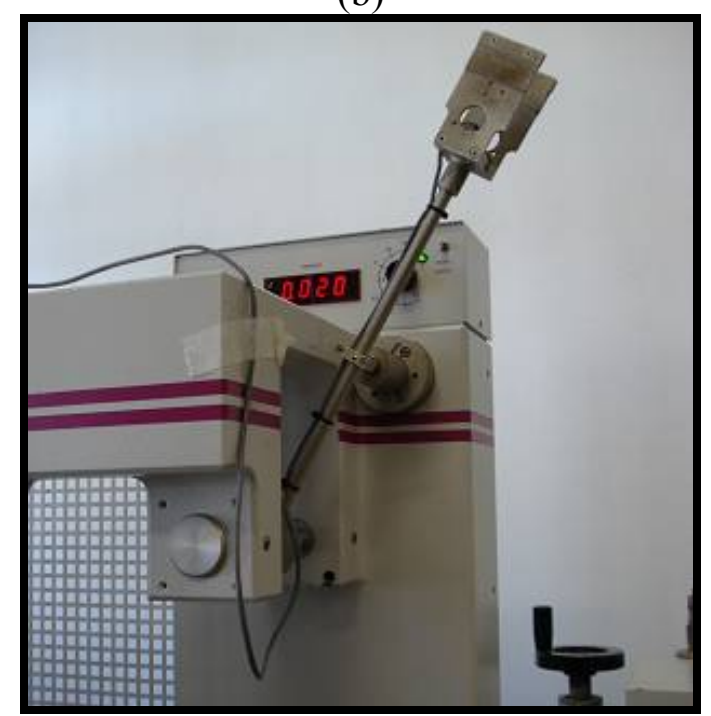

(d)

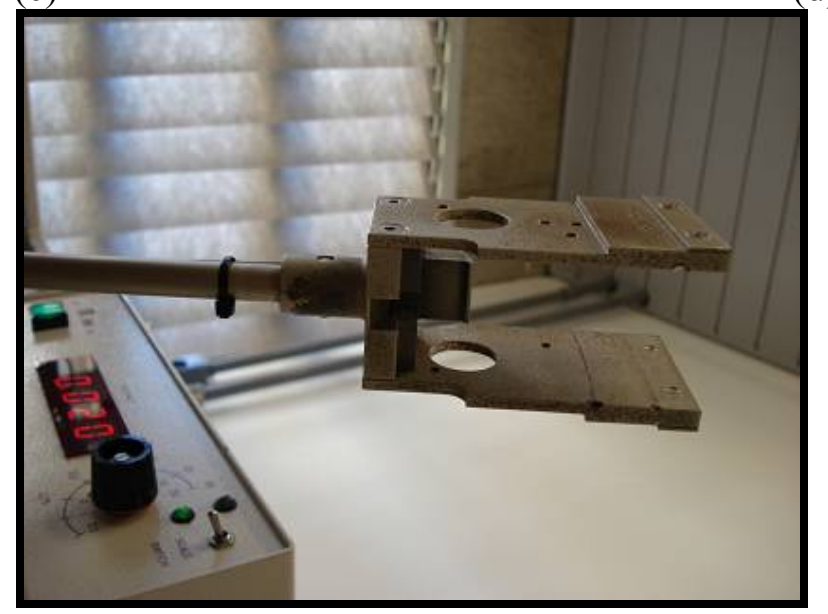

(e)

Figura 5.22: Ensaio dos corpos-de-prova de impacto: (a) e (b) máquina de impacto instrumentada CEAST; (c) base para fixação do corpo-de-prova; (d) pêndulo na posição de início do ensaio; (e) detalhe do pêndulo. 
Foram ensaiados dez corpos-de-prova fabricados com o pélete de cor verde e dez corposde-prova fabricados com o pélete de cor branca. A energia de impacto, expressa em $\mathrm{J} / \mathrm{m}$ e/ou $\mathrm{kJ} / \mathrm{m}^{2}$, foi obtida por meio da energia utilizada para romper o corpo-de-prova. Ela foi registrada no mostrador eletrônico da máquina de impacto instrumentada CEAST. 


\section{RESULTADOS E ANÁLISE}

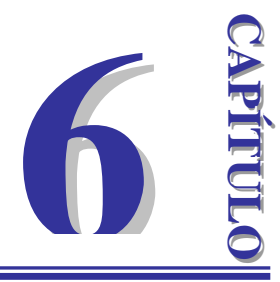

\section{1- ENSAIO DE BEILSTEIN}

O ensaio de Beilstein não detectou vestígio de contaminação com poli (cloreto de vinila) (PVC) em todas as amostras: branca, azul, vermelha, marrom e verde. Isto pode ser comprovado pela permanência da coloração amarela da chama, figura 6.1.

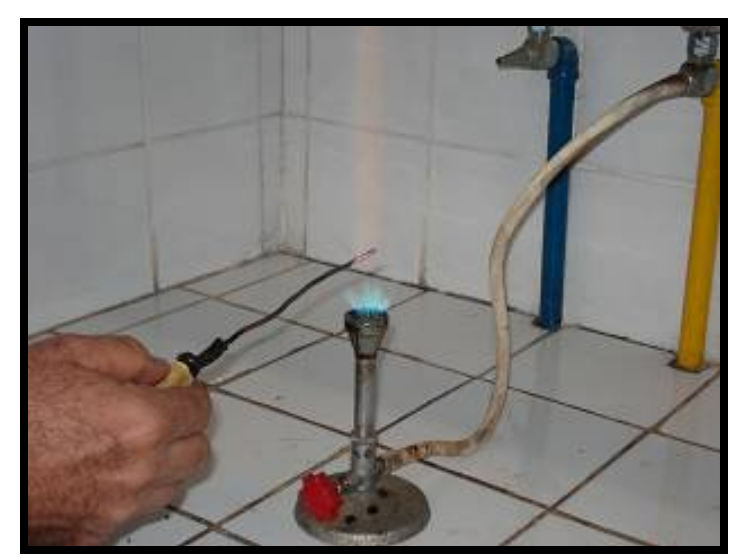

Figura 6.1: Resultado negativo do ensaio de Beilstein para identificação de halogênios.

\section{2- ANÁLISE TÉRMICA}

Os resultados da análise térmica são apresentados em forma de curvas, que contêm informações a respeito do parâmetro medido, em função da temperatura.

\subsection{1- Calorimetria Exploratória Diferencial}

Devido à uniformidade das curvas de DSC, estão ilustradas na figura 6.2 apenas as curvas das amostras de coloração verde e branca, respectivamente. As demais estão no anexo B. 


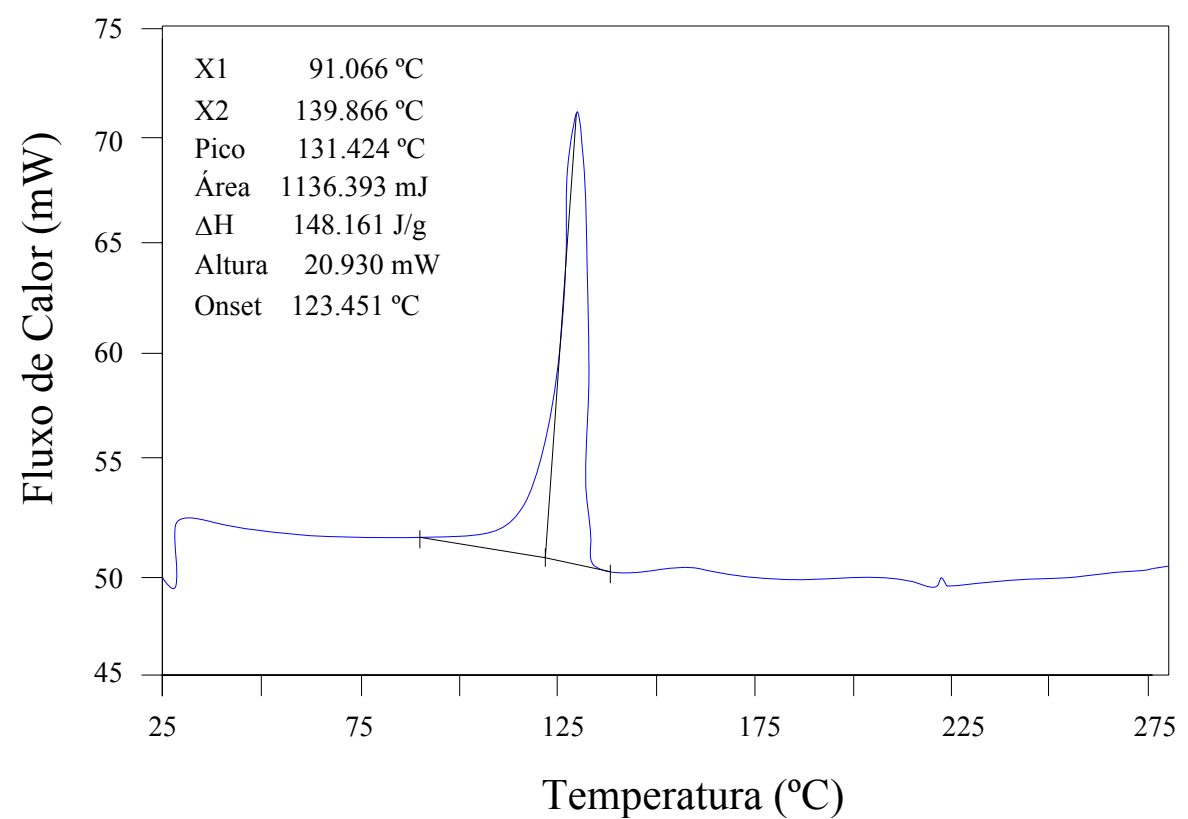

(a)

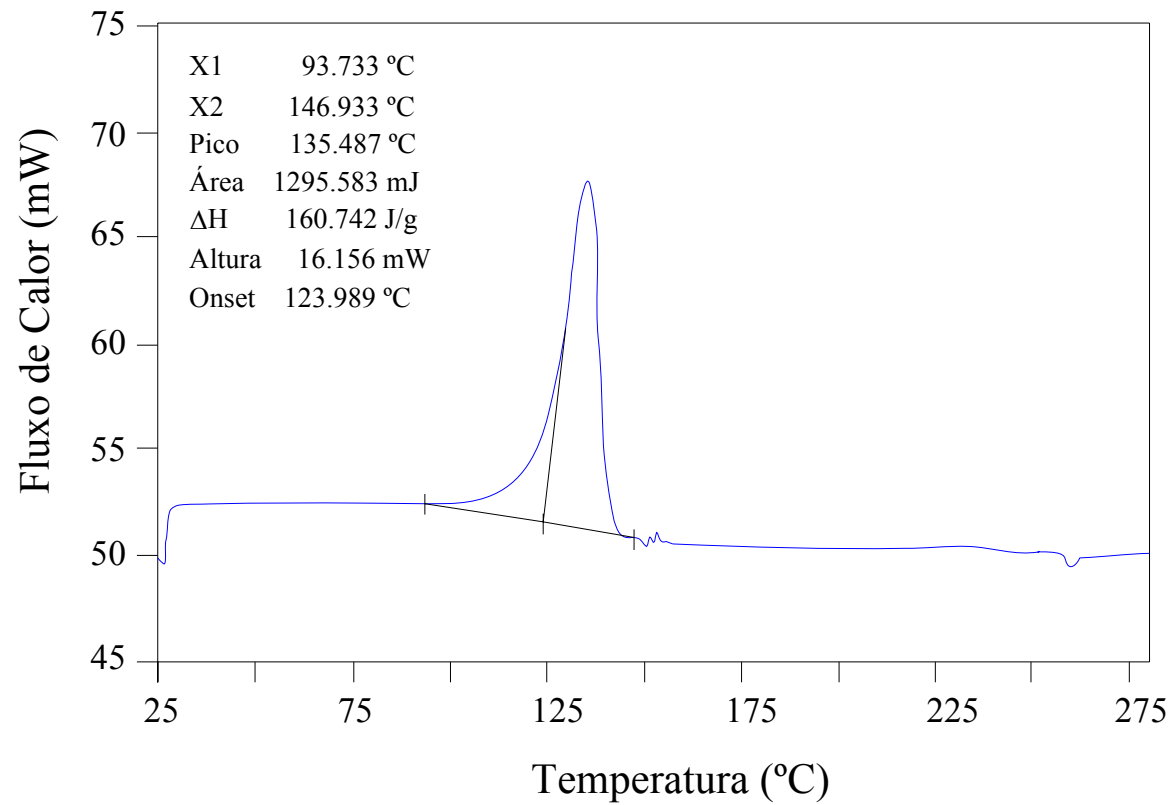

(b)

Figura 6.2: Curvas de DSC: (a) amostra verde de PEAD; (b) amostra branca de PEAD.

A tabela 6.1 apresenta os resultados obtidos para todas as amostras, isto é, temperatura de fusão cristalina $\left(T_{M}\right)$, entalpia de fusão $(\Delta H)$, temperatura no início da fusão $\left(T_{\text {onset }}\right)$ e o grau de cristalinidade $(\chi)$. 
Tabela 6.1: Resultados do ensaio de DSC.

\begin{tabular}{ccccc}
\hline Amostra & $\mathbf{T}_{\mathbf{M}}\left({ }^{\circ} \mathbf{C}\right)$ & $\Delta \mathbf{H}(\mathbf{J} / \mathbf{g})$ & $\mathbf{T}_{\text {onset }}\left({ }^{\circ} \mathbf{C}\right)$ & $\chi(\%)$ \\
\hline Branca & 135,5 & 160,7 & 123,9 & 55 \\
\hline Azul & 130,9 & 182,4 & 122,4 & 62 \\
\hline Vermelha & 130,6 & 172,8 & 122,3 & 59 \\
\hline Marrom & 129,8 & 170,5 & 122,6 & 58 \\
\hline Verde & 131,4 & 148,2 & 123,5 & 51 \\
\hline
\end{tabular}

Para obter o grau de cristalinidade do PEAD reciclado, utilizou-se a entalpia de fusão do PEAD 100\% hipoteticamente cristalino, $293 \mathrm{~J} / \mathrm{g}$, conforme descrito no anexo A.

As curvas de DSC obtidas para todas as amostras apresentam apenas um pico de fusão, que varia entre $129,82{ }^{\circ} \mathrm{C}$ (amostra marrom) e $135,49{ }^{\circ} \mathrm{C}$ (amostra branca). A presença de um único pico de fusão na temperatura de fusão do $\mathrm{PEAD}$, em torno de $137^{\circ} \mathrm{C}$ (tabela 3.1 ), comprova a isenção de possíveis contaminantes, como PET e PP. Pode-se perceber também que o formato do pico de fusão está bem definido para todas as curvas de DSC, comprovando que o material fornecido pela Reciclagem Nova Ribeirão é bastante uniforme, mesmo apresentando variação na coloração.

Pode-se perceber que houve uma pequena variação na temperatura de fusão entre as amostras de PEAD, indicando que a morfologia cristalina dessas amostras é uniforme. A entalpia de fusão e, conseqüentemente, o grau de cristalinidade, também apresentam valores bem próximos, comprovando a uniformidade do PEAD reciclado fornecido pela empresa de Ribeirão Preto.

Devido à uniformidade das amostras, escolheu-se apenas o PEAD verde e o branco para determinar a composição por meio do TG e realizar os ensaios mecânicos. Esta escolha se deu por eles apresentarem um grau de cristalinidade mais distante do PEAD puro, entre 75 a $95 \%$ (tabela 3.2), isto é, foram utilizados os materiais reciclados de pior qualidade, com o intuito de não obter características de resistência superiores às dos materiais disponíveis no mercado.

A diferença entre a temperatura e a entalpia de fusão para as amostras vermelha e marrom é muito pequena, $0,57 \%$ e $1,33 \%$ respectivamente. Portanto elas podem ser consideradas como uma única amostra, apresentando apenas coloração diferente. 
Por meio da curva de DSC, obtida para as amostras de cores verde e branca de PEAD, figura 6.2, pode-se comprovar que o equipamento utilizado no ensaio tinha a configuração de DSC de fluxo de calor, pois os eventos exotérmicos têm variação positiva de entalpia, apresentando picos ascendentes na curva de DSC.

\subsection{2- Termogravimetria}

O resultado desta análise térmica é mostrado sob a forma de um gráfico relacionando a massa residual com a temperatura, figura 6.3.

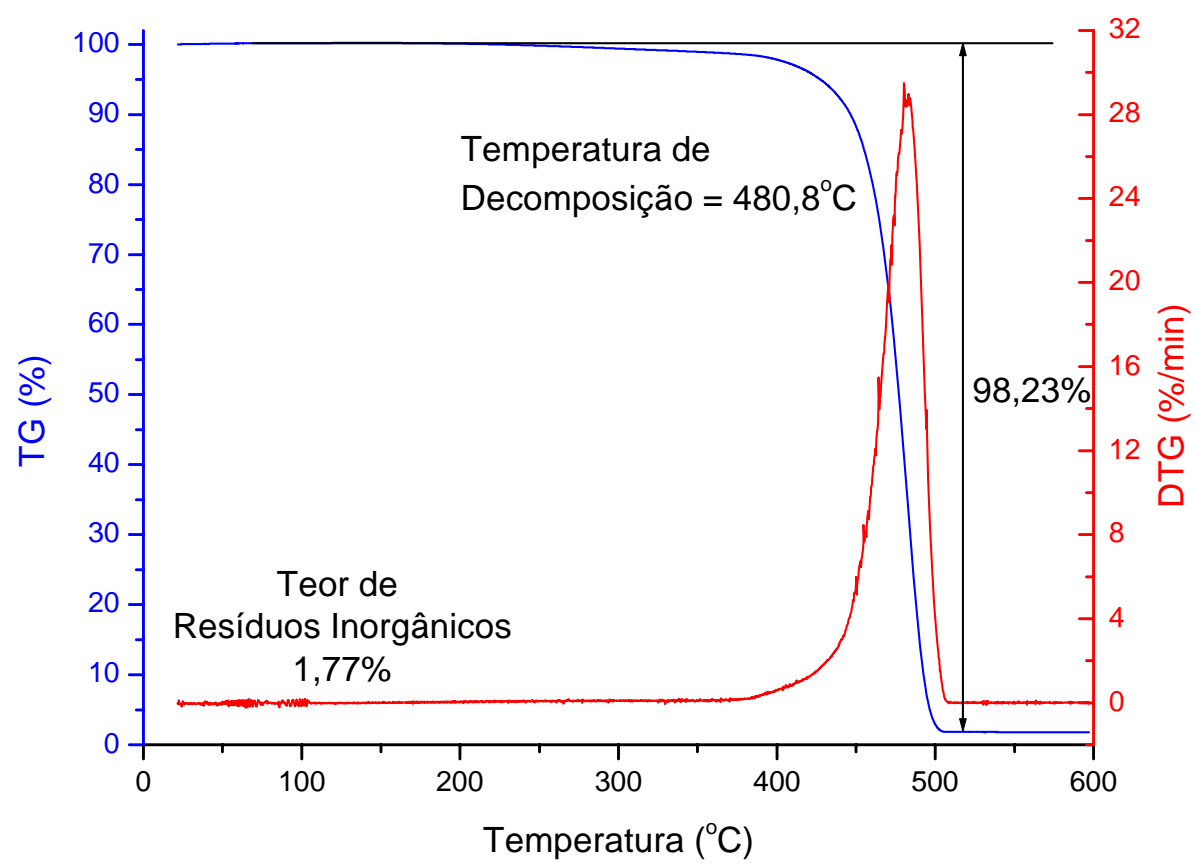

(a) 


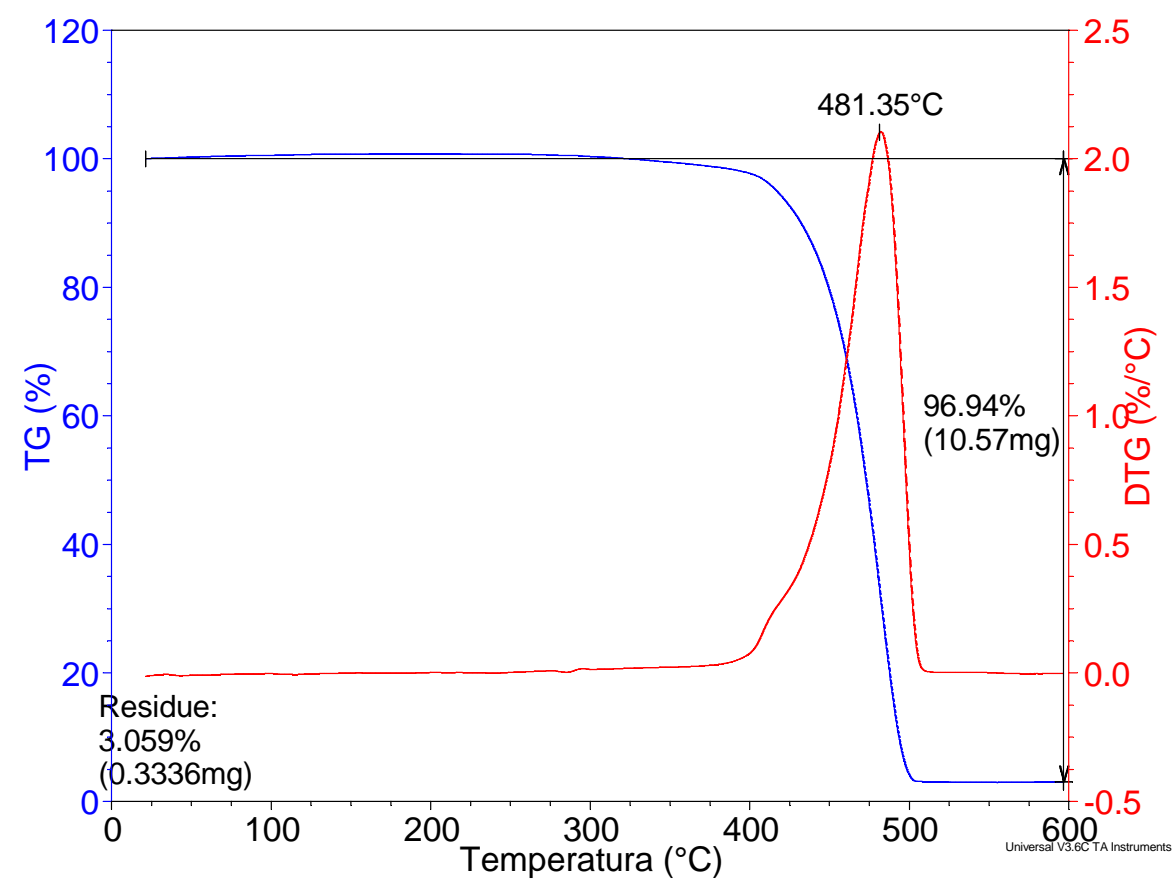

(b)

Figura 6.3: Curvas TG (-) e DTG (-): (a) amostra PEAD verde sob atmosfera dinâmica de $\mathrm{N}_{2}$. Massa da amostra $14,0940 \mathrm{mg}$, vazão de gás $50 \mathrm{ml} / \mathrm{min}$, suporte da amostra de alumina, razão de aquecimento $10^{\circ} \mathrm{C} / \mathrm{min}$;

(b) amostra PEAD branca sob atmosfera dinâmica de $\mathrm{N}_{2}$. Massa da amostra 10,9043 mg, vazão de gás $50 \mathrm{ml} / \mathrm{min}$, suporte da amostra de alumina, razão de aquecimento $10^{\circ} \mathrm{C} / \mathrm{min}$.

As amostras de PEAD verde e branco apresentaram comportamentos semelhantes. Por isso, os resultados serão apresentados simultaneamente. A amostra verde (e a branca) não apresenta mudança em sua massa até a temperatura de $290^{\circ} \mathrm{C}$ (e $320{ }^{\circ} \mathrm{C}$ ). A partir dessa temperatura, observa-se uma diminuição acentuada de sua massa inicial, até por volta de $510^{\circ} \mathrm{C}$ $\left(520^{\circ} \mathrm{C}\right)$. Nesse intervalo de temperatura, a amostra perde 98,23\% (97\%) de sua massa inicial, devido à decomposição/degradação do polímero. A temperatura de decomposição do polímero, medida no pico da curva DTG, é de $480,8^{\circ} \mathrm{C}\left(481^{\circ} \mathrm{C}\right)$. Entre $510^{\circ} \mathrm{C}$ e $600^{\circ} \mathrm{C}\left(520^{\circ} \mathrm{C}\right.$ e $\left.600^{\circ} \mathrm{C}\right)$, a curva TG exibe um patamar, onde não há perda significativa de massa. O teor de resíduos estáveis a $600^{\circ} \mathrm{C}$ é de $1,77 \%(3 \%)$, que equivale a $0,25 \mathrm{mg}(0,33 \mathrm{mg})$ da amostra utilizada.

Essa pequena porcentagem de resíduos, tanto na amostra de PEAD de coloração verde quanto na amostra de coloração branca, pode corresponder à pigmentação inorgânica ou a um aditivo lubrificante. Elas não são significativas, pois em uma resina virgem, sua pigmentação pode corresponder a até 3\% da massa. 
Por meio da curva de DTG, pode-se comprovar que as amostras de PEAD reciclado de coloração verde e branca são compostas por $98,23 \%$ e $96,94 \%$ de polietileno de alta densidade respectivamente, já que não houve sobreposição de reações e foram caracterizadas por apenas um evento térmico, representado pela temperatura de decomposição.

\section{3- ENSAIOS MECÂNICOS}

Os resultados dos ensaios de tração e de compressão são obtidos por meio de curvas típicas tensão $x$ deformação. Para o ensaio de flexão, é mais usual apresentar a curva força $x$ deslocamento. Os resultados podem ser expressos e analisados mais facilmente quando são fornecidos a média e o desvio padrão, parâmetros estatísticos exigidos pelas normas da ASTM. Foram traçados gráficos para todos os cp's ensaiados. Para efeito de ilustração, os gráficos do corpo-de-prova de número 1 (CP1), conforme numeração constante no anexo $\mathrm{B}$, serão apresentados nos itens seguintes. As demais curvas e os resultados individuais dos corpos-deprova estão apresentados no anexo B.

\subsection{1- Ensaio de Tração}

A figura 6.4 ilustra, de maneira geral, o comportamento do PEAD de coloração verde e branca.

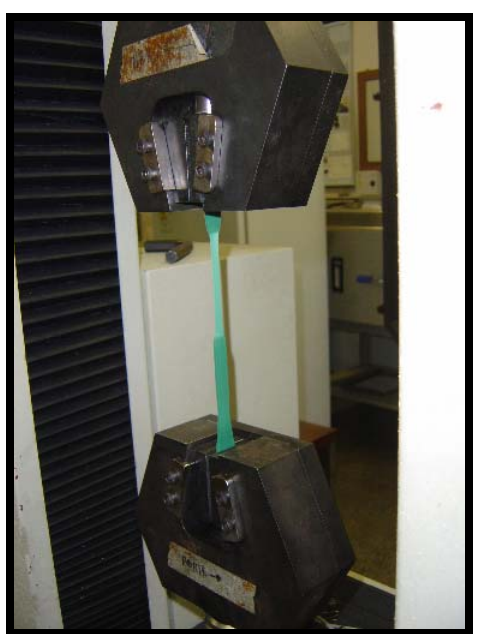

(a)

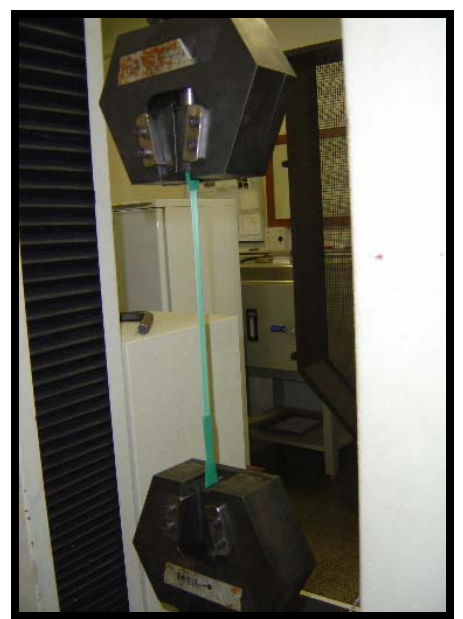

(b)

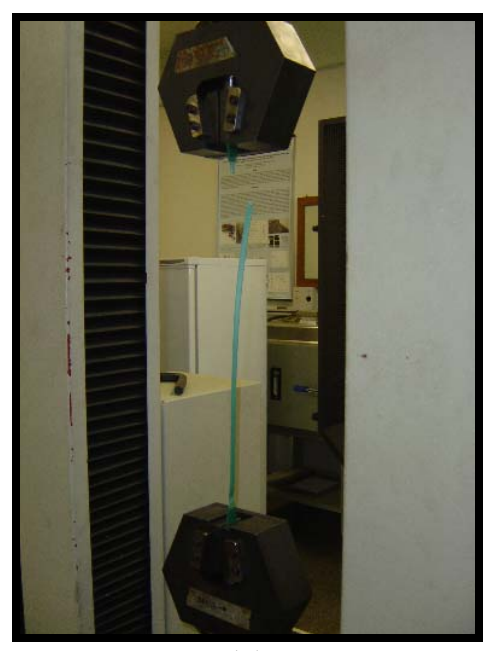

(c) 


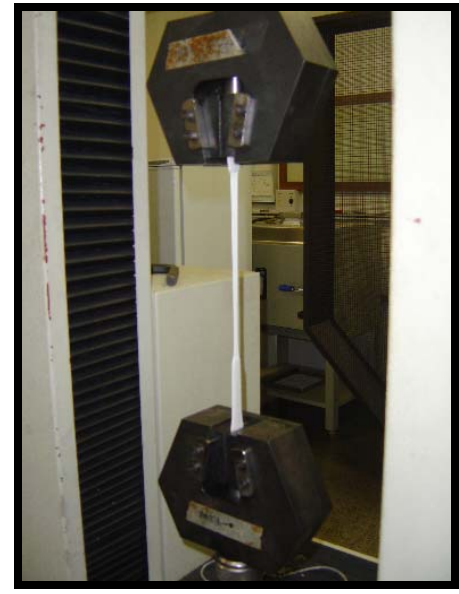

(d)

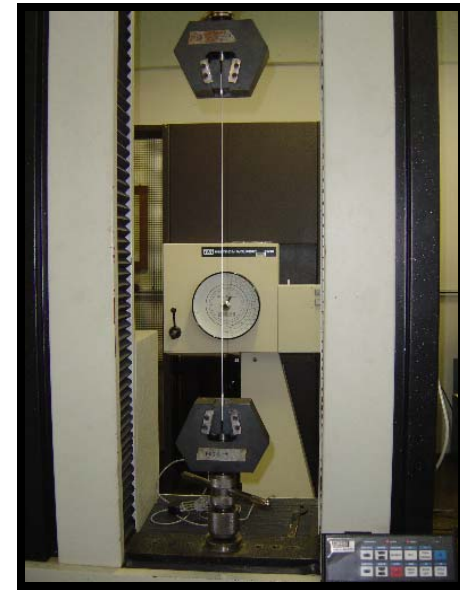

(e)

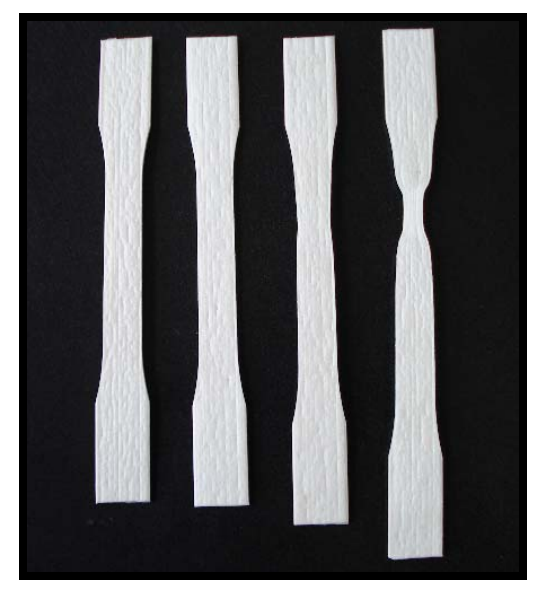

(f)

Figura 6.4: Ensaio dos corpos-de-prova de tração: (a), (b) e (c) ensaio com o corpo-de-prova verde;

(d) e (e) ensaio com o corpo-de-prova branco; (f) estricção nos corpos-de-prova brancos.

As curvas tensão $x$ deformação obtidas para o corpo-de-prova 1, no ensaio de tração para o PEAD reciclado de coloração verde e de coloração branca, estão apresentadas na figura 6.5. Essas curvas representam, de maneira geral, os resultados obtidos em todos os ensaios.

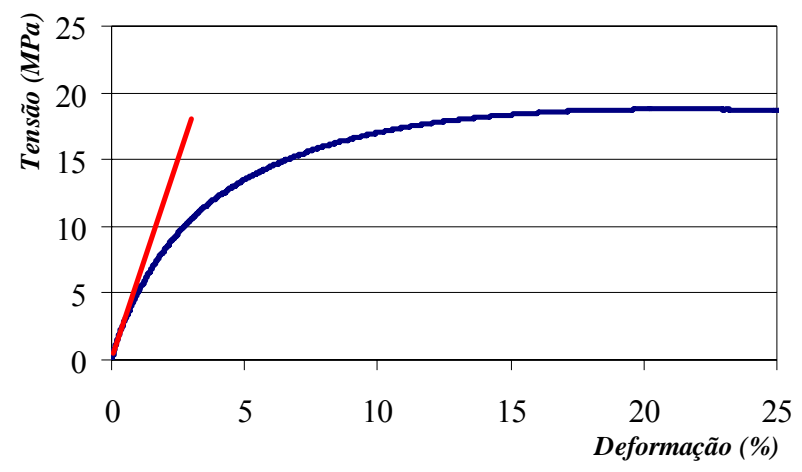

(a)

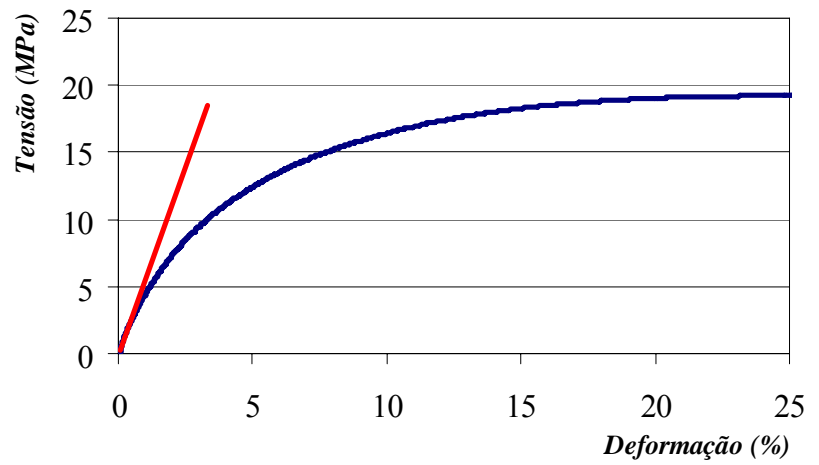

(b) 


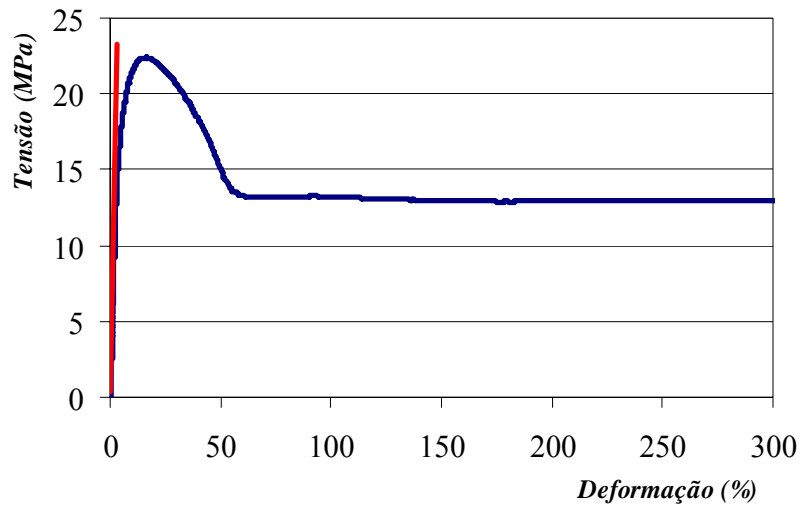

(c)

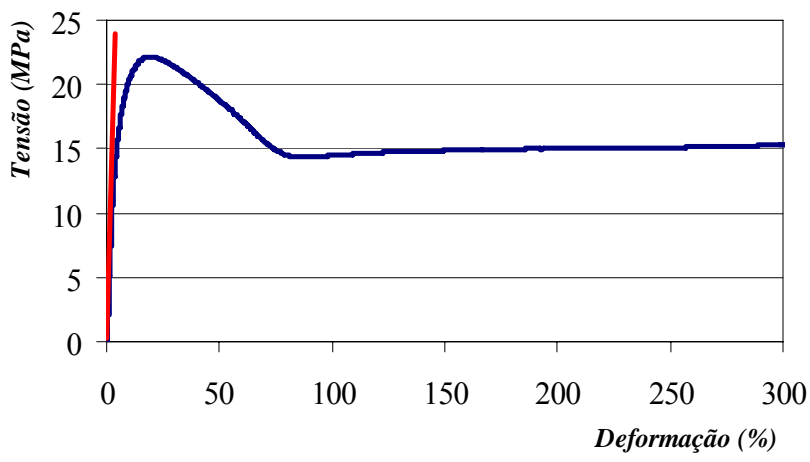

(d)

Figura 6.5: Gráficos tensão $x$ deformação para o ensaio de tração: (a) CP 1 branco ensaiado com extensômetro; (b) CP 1 verde ensaiado com extensômetro; (c) CP 1 branco ensaiado com transdutor de deslocamento acoplado à máquina; (d) CP 1 verde ensaiado com transdutor de deslocamento acoplado à máquina.

As propriedades mecânicas de resistência e de deformação no escoamento, tensão e deformação na ruptura, elongação percentual e módulo de elasticidade tangente estão representadas na tabela 6.2. Conforme as prescrições normativas, o módulo de elasticidade foi obtido para a velocidade de $5 \mathrm{~mm} / \mathrm{min}$, os demais parâmetros foram obtidos para velocidade de $50 \mathrm{~mm} / \mathrm{min}$. 
Tabela 6.2: Resultados do ensaio de tração.

\begin{tabular}{lcccc}
\hline \multirow{2}{*}{\multicolumn{1}{c}{ Propriedades }} & \multicolumn{4}{c}{ Resultados } \\
\cline { 2 - 5 } & \multicolumn{2}{c}{ PEAD Branco } & \multicolumn{2}{c}{ PEAD Verde } \\
\cline { 2 - 5 } & Média & $\begin{array}{c}\text { Desvio } \\
\text { Padrão }\end{array}$ & Média & $\begin{array}{c}\text { Desvio } \\
\text { Padrão }\end{array}$ \\
\hline Resistência no escoamento $(\mathrm{MPa}) *$ & 21,85 & 0,37 & 22,24 & 0,66 \\
\hline Deformação no escoamento $(\mathrm{mm} / \mathrm{mm})$ & 0,168 & 0,008 & 0,17 & 0,009 \\
\hline Tensão na ruptura $(\mathrm{MPa})$ & $14,15 * *$ & 0,28 & 15,36 & 0,92 \\
\hline Deformação na ruptura $(\mathrm{mm} / \mathrm{mm})$ & $>6,54$ & 0,15 & 4,38 & 2,95 \\
\hline Alongamento na ruptura $(\%)$ & $>654$ & 15 & 438 & 295 \\
\hline Módulo de elasticidade tangente $(\mathrm{MPa})$ & 598 & 8 & 547 & 11 \\
\hline * Tensão máxima ocorreu no escoamento. & \multicolumn{4}{c}{} \\
** Ensaio foi interrompido, pois foi atingido o final do cursor da máquina. \\
\hline
\end{tabular}

Os polímeros podem ser classificados a partir da curva tensão $x$ deformação, por meio do comportamento dúctil ou frágil (Canevarolo, 2000). Conforme observado na figura 6.5 e na tabela 6.2, o PEAD reciclado possui um comportamento dúctil, devido a valores elevados de deformação e/ou alongamento antes da ruptura. A estriç̧ão se inicia quando é atingida a tensão máxima, e se prolonga por toda a extensão do corpo-de-prova com seção reduzida, devido ao material apresentar o comportamento de estiramento a frio.

No PEAD, geralmente a tensão na ruptura é superior à tensão no escoamento, proveniente de uma orientação molecular intensa. Esse comportamento evidencia que a orientação molecular não é intensa para o PEAD testado, conforme observado na figura 6.5.

$\mathrm{Na}$ fase inicial, os materiais ensaiados tiveram um comportamento hookeano, obtendo-se o módulo de elasticidade tangencial. O PEAD reciclado de coloração branca, quando comparado com o PEAD de coloração verde, apresenta maior módulo de elasticidade, conforme esperado, pois o módulo aumenta com o grau de cristalinidade.

Para efeito de comparação, a tabela 6.3 apresenta os valores do PEAD puro, indicados na tabela 3.3. 
Tabela 6.3: Propriedades de tração para o PEAD virgem.

Fonte:http://www.ipq.com.br/index.php?secao $=$ catalogo\&resina $=$ pead $\&$ processo $=9 \&$ produto $=10$;

\begin{tabular}{lc}
\hline \multicolumn{1}{c}{ Propriedades } & PEAD Puro \\
\hline Tensão no escoamento (em placa) (MPa) & 28 \\
\hline Tensão na ruptura (em palca) (MPa) & 29 \\
\hline Alongamento na ruptura (em placa) (\%) & 860 \\
\hline Módulo de elasticidade tangente (MPa)* & 900 \\
\hline *Fonte: www.incomplast.com.br/f_poliet.htm. & \\
\hline
\end{tabular}

A resistência à tração no escoamento e o módulo de elasticidade para o PEAD reciclado diferiram $22 \%$ e $33 \%$, respectivamente, quando comparados ao PEAD puro, tabela 3.3 , fato resultante dos problemas ocorridos durante o processamento do material, já que a composição é praticamente similar à do material puro, conforme os resultados do ensaio de TG e DSC.

A partir das curvas na figura 6.5 e dos valores apresentados na tabela 6.2, pode-se comprovar que o polietileno tem como características, no ensaio de tração, baixo módulo de elasticidade, baixa tensão de escoamento, porém elevada elongação.

\subsection{2- Ensaio de Compressão}

A curva tensão $x$ deformação, figura 6.6, indica o comportamento do corpo-de-prova 1, que é representativo do comportamento geral observado nos ensaios. As demais curvas e os resultados individuais dos corpos-de-prova estão apresentados no anexo B.

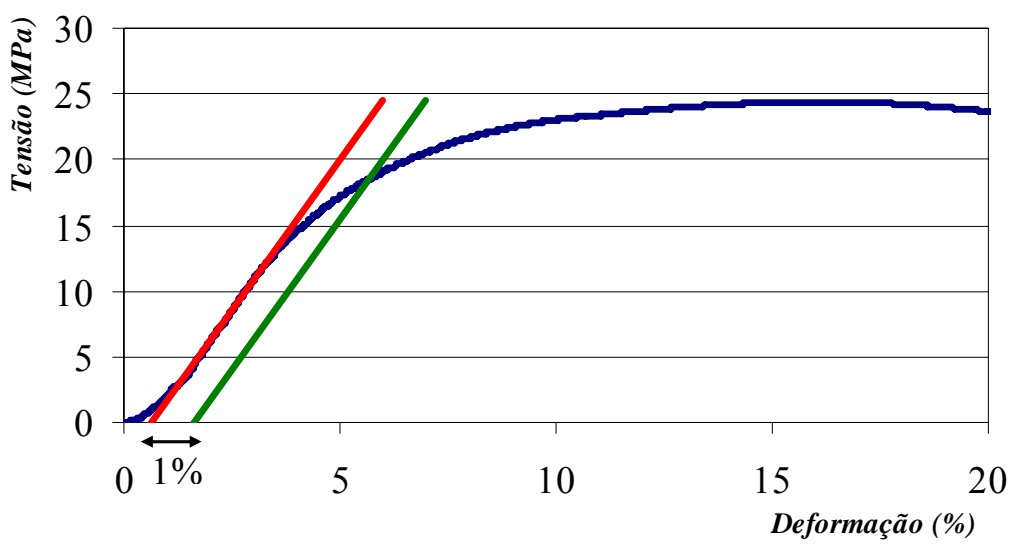

(a) 


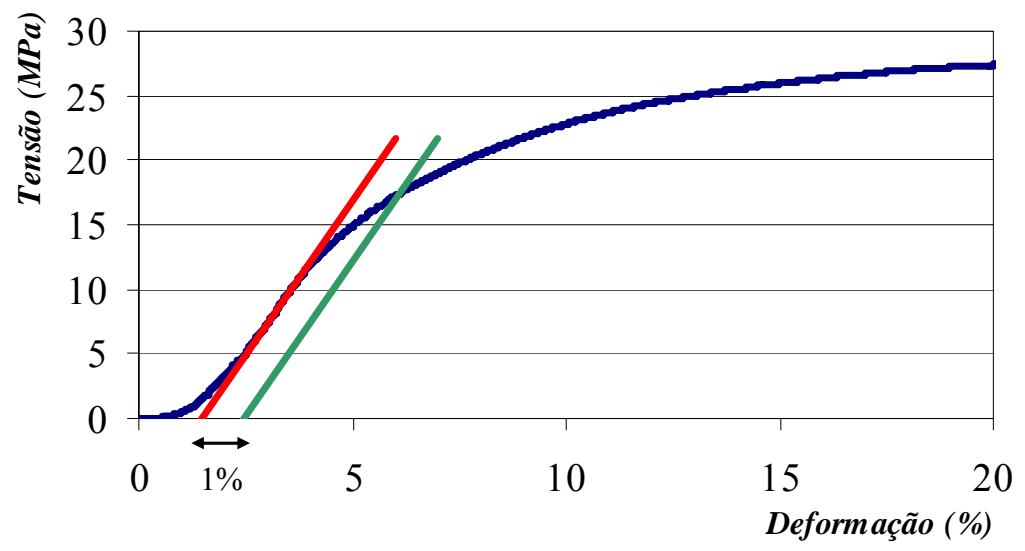

(b)

Figura 6.6: Gráficos tensão $x$ deformação para o ensaio de compressão: (a) corpo-de-prova branco;

(b) corpo-de-prova verde.

O módulo de elasticidade foi obtido no trecho linear do diagrama, a partir do coeficiente angular da reta vermelha, mostrada na figura 6.6.

O ponto dado pela intersecção da reta vermelha com o eixo de deformação é considerado como a origem desse eixo, a partir do qual se distancia $1 \%$ de deformação, obtendo-se o ponto de deformação deslocado. A partir deste ponto, traça-se uma reta, a verde, paralela à reta vermelha, para se obter a tensão de escoamento deslocada, dada pela intersecção da curva tensão $x$ deformação com a reta verde. Maiores detalhes estão apresentados no anexo A. A tensão no escoamento é o máximo valor de tensão no trecho linear do diagrama.

A média e o desvio padrão dos parâmetros obtidos para os 10 corpos-de-prova ensaiados estão apresentados na tabela 6.4 . 
Tabela 6.4: Resultados do ensaio de compressão.

\begin{tabular}{lcccc}
\hline \multirow{2}{*}{\multicolumn{1}{c}{ Propriedades }} & \multicolumn{4}{c}{ Resultados } \\
\cline { 2 - 5 } & \multicolumn{2}{c}{ PEAD Branco } & \multicolumn{2}{c}{ PEAD Verde } \\
\cline { 2 - 5 } & Média & $\begin{array}{c}\text { Desvio } \\
\text { Padrão }\end{array}$ & Média & $\begin{array}{c}\text { Desvio } \\
\text { Padrão }\end{array}$ \\
\hline Resistência* $(\mathrm{MPa})$ & 26,20 & 1,19 & 28,72 & 2,72 \\
\hline Tensão no escoamento $(\mathrm{MPa})$ & 14,11 & 0,63 & 14,25 & 0,87 \\
\hline Deformação no escoamento $(\mathrm{mm} / \mathrm{mm})$ & 0,041 & 0,003 & 0,049 & 0,007 \\
\hline Tensão de escoamento deslocada $(\mathrm{MPa})$ & 16,84 & 0,52 & 16,69 & 0,71 \\
\hline Módulo de elasticidade $(\mathrm{MPa})$ & * Tensão máxima & 20 & 245 & 34 \\
\hline \multicolumn{4}{l}{} \\
\hline
\end{tabular}

Conforme observado na figura 6.6, o PEAD possui um comportamento dúctil quando submetido à compressão monotônica. Além disso, o módulo de elasticidade da amostra branca foi maior que o da verde, devido a ela ter maior grau de cristalinidade.

$\mathrm{Na}$ tabela 6.4, pode-se perceber que o PEAD de coloração branca teve resultados praticamente idênticos ao de coloração verde. A propriedade que apresentou maior diferença entre os tipos de amostras foi o módulo de elasticidade.

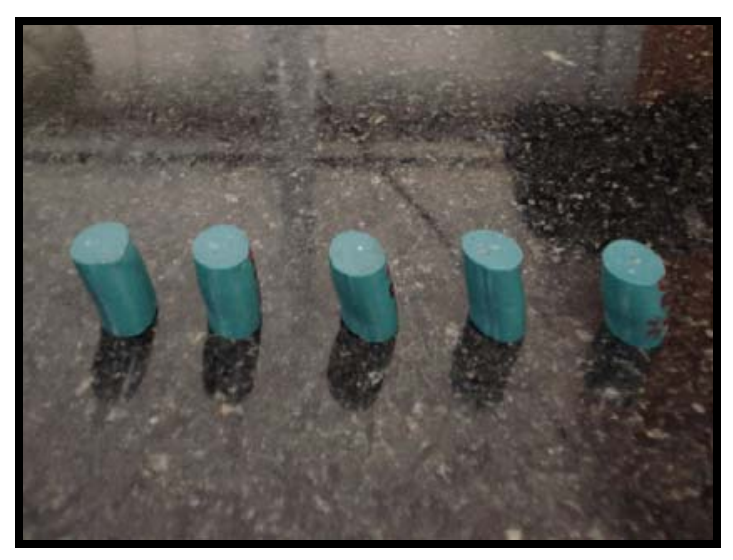

(a)

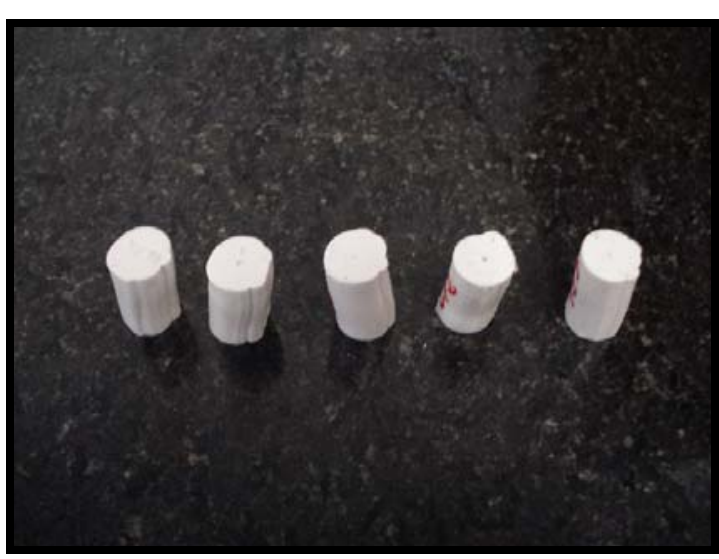

(b)

Figura 6.7: Ensaio dos corpos-de-prova de compressão: (a) corpos-de-prova verde depois do ensaio; (b) corpos-de-prova branco depois do ensaio.

As seções transversais dos corpos-de-prova de compressão, ilustrados na figura 6.8, apresentam efeitos concentradores de tensão. Esses efeitos não foram avaliados, por não ser o objetivo deste estudo. 


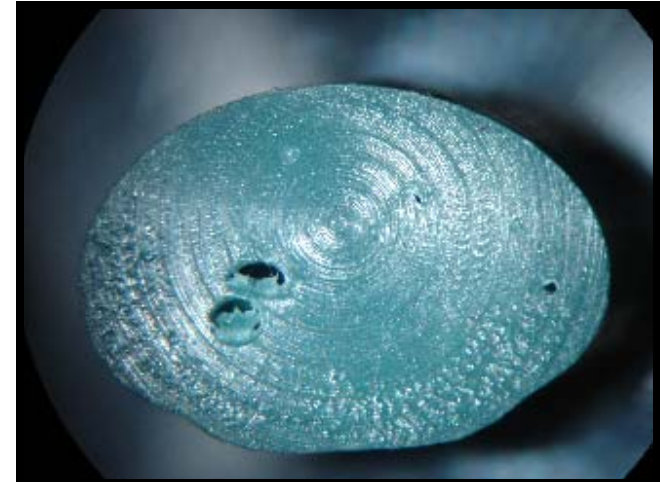

(a)

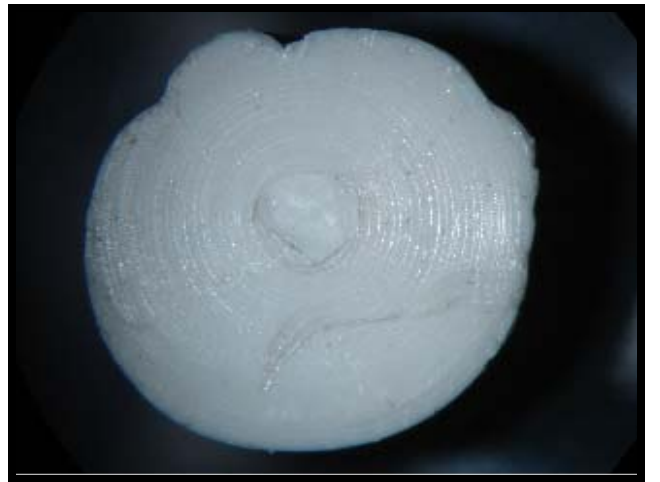

(b)

Figura 6.8: Seção transversal dos corpos-de-prova de compressão: (a) corpo-de-prova verde; (b) corpo-de-prova branco.

\subsection{3- Ensaio de Flexão}

A figura 6.9 ilustra a deformação máxima obtida para o ensaio de flexão.

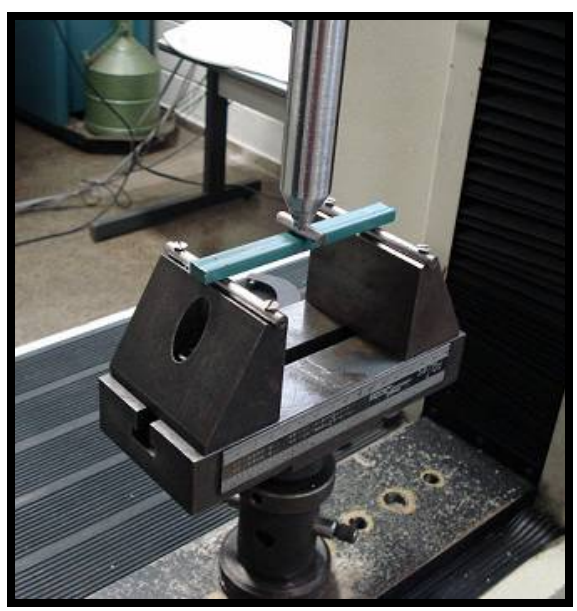

(a)

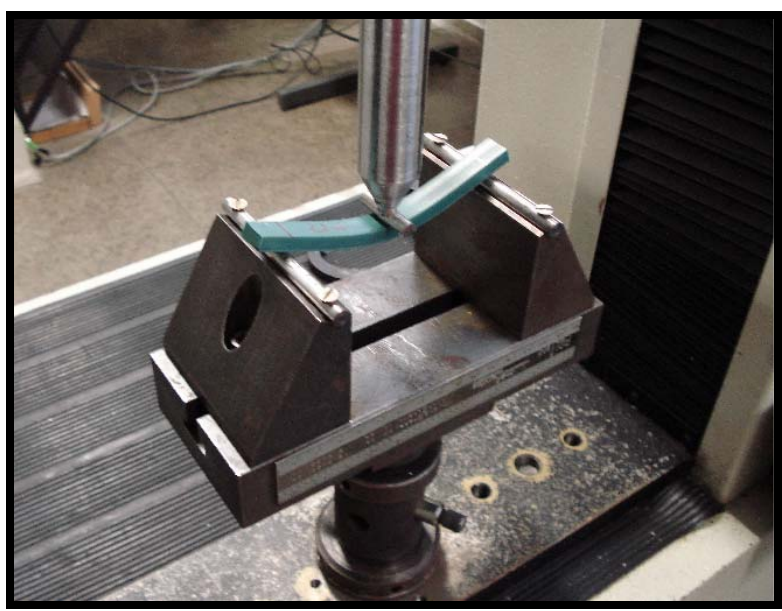

(b) 


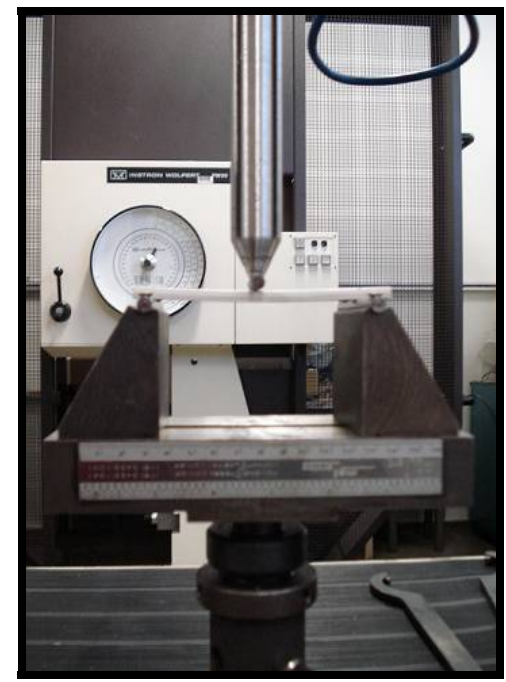

(c)

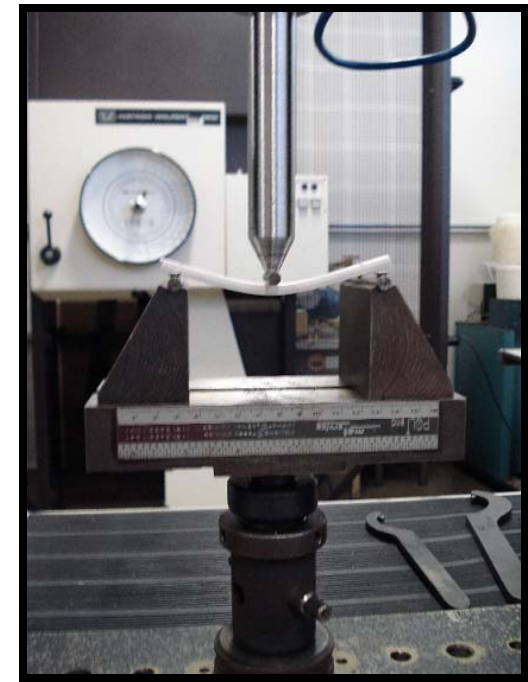

(d)

Figura 6.9: Ensaio dos corpos-de-prova de flexão: (a) corpo-de-prova verde ao iniciar o ensaio de flexão; (b) corpo-

de-prova verde quando atingiu a deformação máxima; (c) corpos-de-prova branco ao iniciar o ensaio de flexão;

(d) corpos-de-prova branco quando atingiu a deformação máxima.

A curva força $x$ deslocamento, figura 6.10, foi obtida para o corpo-de-prova 1 e representa o comportamento geral observado no ensaio de flexão, para os dez corpos-de-prova ensaiados.

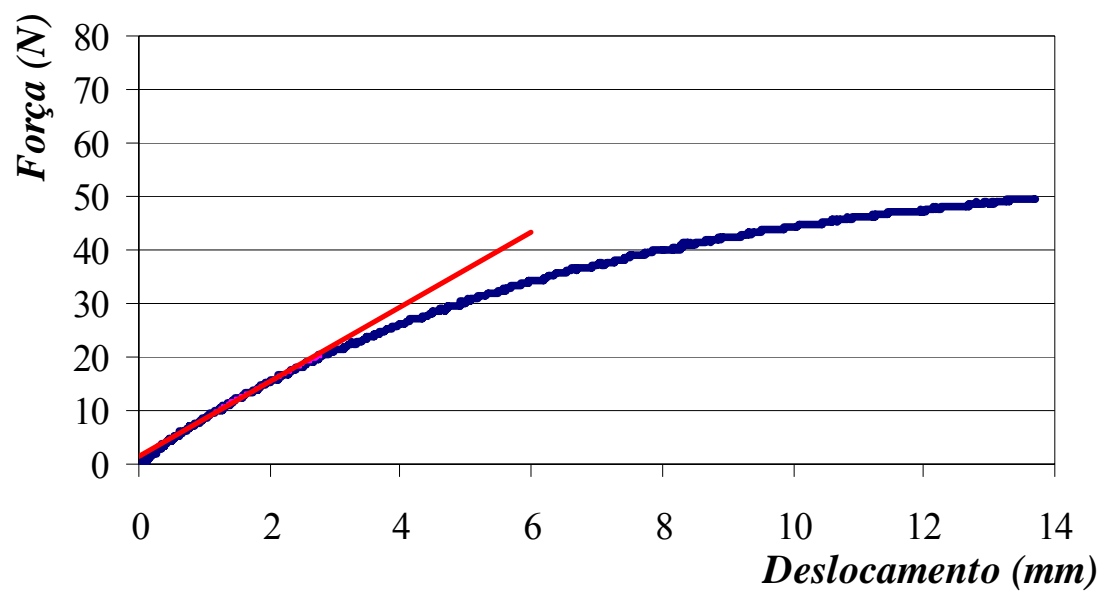

(a) 


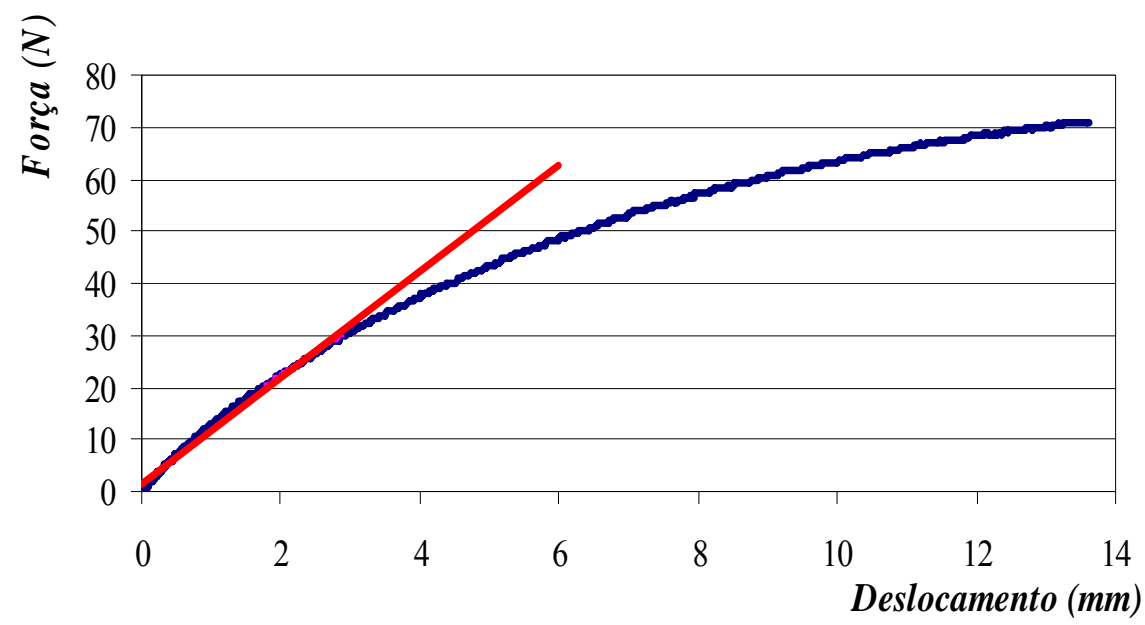

(b)

Figura 6.10: Gráficos força $x$ deslocamento para o ensaio de flexão: (a) corpo-de-prova branco;

(b) corpo-de-prova verde.

A média e o desvio padrão de todos os corpos-de-prova ensaiado estão apresentados na tabela 6.5 .

Tabela 6.5: Resultados do ensaio de flexão.

\begin{tabular}{lcccc}
\hline \multicolumn{1}{c}{ Propriedades } & PEAD Branco & \multicolumn{2}{c}{ Resultados } \\
& Média & $\begin{array}{c}\text { Desvio } \\
\text { Padrão }\end{array}$ & Média & $\begin{array}{c}\text { Verde } \\
\text { Desvio } \\
\text { Padrão }\end{array}$ \\
\hline $\begin{array}{l}\text { Força máxima correspondente a 5\% de } \\
\text { deformação (N) }\end{array}$ & 48 & 2 & 72 & 2 \\
\hline Módulo de elasticidade tangente (MPa) & 805 & 25 & 719 & 23 \\
\hline $\begin{array}{l}\text { Resistência correspondente a 5\% de } \\
\text { deformação }(\mathrm{MPa})\end{array}$ & 17,64 & 0,35 & 18,73 & 0,37 \\
\hline
\end{tabular}

O ensaio foi concluído para deformação máxima de $5 \%$, pois não atingiu a ruptura antes dessa deformação. Com isso, pode-se perceber que curva apresenta ponto de escoamento.

O módulo de elasticidade foi obtido a partir da equação disponível no anexo A.

A resistência correspondente a 5\% de deformação foi próxima para as duas amostras ensaiadas. Essa pequena diferença pode ter ocorrido devido ao corpo-de-prova de coloração branca possuir seções com "rechupes", quando comparadas ao corpo-de-prova de coloração 
verde. Já o módulo de elasticidade da amostra branca foi maior, fato proveniente de ele ter maior grau de cristalinidade. Também observado no ensaio de tração e de compressão.

Para efeito de comparação, a tabela 6.6 apresenta os valores do PEAD puro, valores indicados na tabela 3.3 .

Tabela 6.6: Propriedades do PEAD virgem.

Fonte: $h t t p: / / w w w . i p q . c o m . b r / i n d e x . p h p ?$ secao $=$ catalogo\&resina $=$ pead $\&$ processo $=9 \&$ produto $=10$;

\begin{tabular}{lc}
\hline \multicolumn{1}{c}{ Propriedades } & PEAD Puro \\
\hline Resistência correspondente a 5\% de deformação (MPa)* & $14-20$ \\
\hline Módulo de elasticidade secante a 2\% ( em placa) (MPa) & 1040 \\
\hline *Fonte: www.planetaplastico.com.br/litera/propfisicas. & \\
\hline
\end{tabular}

O módulo de elasticidade na flexão, do PEAD branco, diferiu $22 \%$ quando comparado com o PEAD virgem, tabela 3.3. A resistência à flexão esteve dentro do limite esperado para o polietileno de alta densidade (www.planetaplastico.com.br/litera/propfisicas).

\subsection{4- Ensaio de Impacto}

As propriedades mecânicas de energia de impacto, quantificada em $\mathrm{J} / \mathrm{m} \mathrm{e} \mathrm{kJ} / \mathrm{m}^{2}$, estão representadas na tabela 6.7. As equações para obtenção desses valores estão apresentados no anexo A.

Tabela 6.7: Resultados do ensaio de impacto.

\begin{tabular}{lcccc}
\hline \multirow{2}{*}{ Propriedades } & \multicolumn{4}{c}{ Resultados } \\
& Média & $\begin{array}{c}\text { Desvio } \\
\text { Padrão }\end{array}$ & Média & $\begin{array}{c}\text { Desvio } \\
\text { Padrão }\end{array}$ \\
\hline Resistência $(\mathrm{J} / \mathrm{m})$ & 137,3 & 8,3 & 137,2 & 3,7 \\
\hline Resistência $\left(\mathrm{kJ} / \mathrm{m}^{2}\right)$ & 13,2 & 0,8 & 12,9 & 0,35 \\
\hline
\end{tabular}




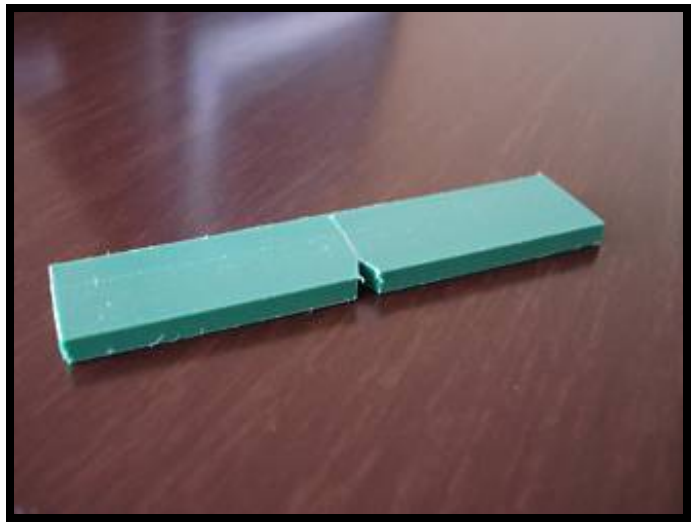

(a)

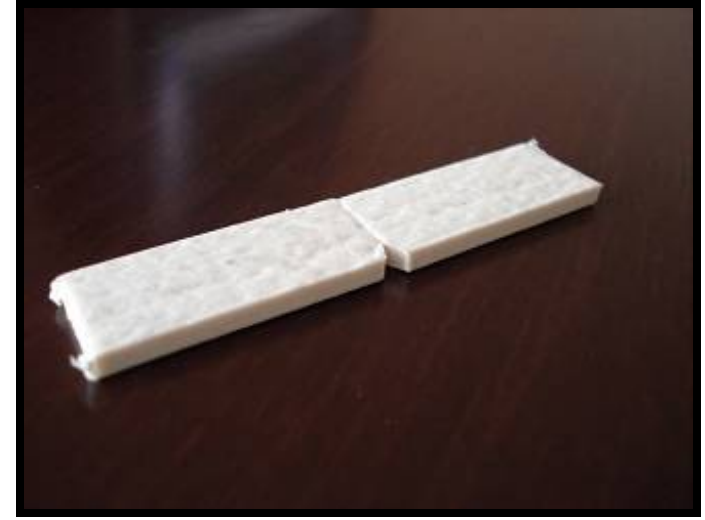

(b)

Figura 6.11: Ensaio dos corpos-de-prova de impacto: (a) corpo-de-prova verde divido em dois pedaços após o ensaio de impacto; (b) corpo-de-prova branco divido em dois pedaços após o ensaio de impacto.

O PEAD reciclado de coloração branca e verde apresentaram resultados muito próximos. Considerando o desvio padrão, o PEAD de coloração branca apresentou menor valor de energia de impacto, conforme esperado, pois a resistência de impacto diminui com o aumento do grau de cristalinidade.

Devido à natureza viscoelástica, os materiais poliméricos apresentam um comportamento extremamente sensível à taxa de deformação. Além disso, o impacto é a solicitação mecânica em que ocorrem elevadas taxas de deformação, (Canevarolo, 2000).

A resistência ao impacto é reduzida devido ao entalhe criar um efeito concentrador de tensão. Já que a presença do entalhe transforma o estado de tensão uniaxial ou biaxial em triaxial, proporcionando uma fratura frágil. Todos os materiais poliméricos apresentam uma velocidade crítica, acima da qual eles se comportam como materiais frágeis. Por isso é que a velocidade de solicitação sob impacto é um parâmetro que influencia na resistência ao impacto.

Para efeito de comparação, a tabela 6.8 apresenta os valores do PEAD puro, provido de entalhe, valores também indicados na tabela 3.3.

Tabela 6.8: Propriedades do PEAD virgem.

Fonte: http://www.ipq.com.br/index.php?secao $=$ catalogo\&resina $=$ pead $\&$ processo $=9 \&$ produto $=10$;

\begin{tabular}{cc}
\hline Propriedades & PEAD Puro \\
\hline Resistência $(\mathrm{J} / \mathrm{m})$ & 140 \\
\hline
\end{tabular}


O PEAD reciclado apresentou resistência ao impacto Izod muito próximo do valor encontrado para o PEAD puro. Comprovando que a resistência ao impacto não foi influenciada pelas inúmeras variáveis que geralmente interferem no ensaio de impacto. Dentre as variáveis que influenciam o ensaio de impacto, pode-se destacar:

- Condições de processamento - temperaturas elevadas de processamento podem causar degradação térmica, diminuindo a resistência ao impacto. A formação de linhas de solda, decorrentes das condições inadequadas de processamento, gera concentração de tensão;

- Grau de cristalinidade - aumentando o grau de cristalinidade, diminui a resistência ao impacto, podendo ocorrer fratura frágil.

Todos os corpos-de-prova ensaiados resultaram em ruptura completa, pois se dividiram em dois pedaços, como será exposto no anexo A. A resistência ao impacto izod não deve ser considerada separadamente, para quantificar a resistência mecânica do material, pois existem polímeros que são sensíveis ao entalhe, porém possuem elevadas propriedades mecânicas.

\section{4- CONSIDERAÇÕES FINAIS}

A estrutura molecular do polímero é responsável pelo seu comportamento mecânico. As ligações entre os átomos da cadeia principal são primárias covalentes e, entre as cadeias poliméricas, as ligações são secundárias, fracas, com baixa energia de ligação. Por esse motivo, os polímeros apresentam resistência mecânica inferior quando comparados com outros materiais, (Canevarolo, 2000).

\subsection{1- Ensaios mecânicos}

Nos ensaios realizados de tração, de compressão e de flexão, pode-se concluir que o módulo de elasticidade do PEAD de coloração branca foi maior do que o relativo à coloração verde, conforme esperado, já que o módulo de elasticidade aumenta com o grau de cristalinidade. O mesmo não aconteceu com a resistência. Esse fato pode ter ocorrido devido à presença de defeitos oriundos do processamento e da tensão de moldagem, pois como observado nas figuras 5.16 e 5.19, os corpos-de-prova de coloração branca apresentam superfícies menos uniformes, 
"rechupes", quando comparados com os de coloração verde. Porém, considerando o desvio padrão, essa diferença não é significativa.

Conforme previsto para os materiais termoplásticos, o módulo de elasticidade de flexão foi maior que o módulo de elasticidade de tração. Entretanto, o módulo de elasticidade de compressão fugiu dos padrões, pois foi menor que o módulo de flexão e até mesmo que o módulo de tração. Segundo Nielsen; Landel (1994), o módulo de elasticidade à tração varia em torno de 80 a 90\% do módulo de elasticidade à flexão, e o módulo de elasticidade à compressão é em torno de $110 \%$ do módulo de elasticidade à flexão. Como se pode perceber, tanto o módulo de elasticidade à tração quanto o módulo de elasticidade à compressão são relacionados com o módulo de elasticidade à flexão, conforme o critério internacional de rigidez, além da dificuldade de se obterem os demais.

Nos ensaios realizados ao longo deste estudo, ambos os módulos de elasticidade, à tração e à compressão, comparados com o módulo à flexão, estão distantes da referência bibliográfica (Nielsen; Landel, 1994). Porém a diferença do módulo à tração, quando comparado ao módulo à flexão, é muito pequena, em torno de 7\% para os corpos-de-prova brancos. Já para os corpos-deprova submetidos à compressão, essa diferença é significativa, fato que pode ter ocorrido devido às dimensões dos corpos-de-prova de compressão estarem distantes das prescrições normativas, além da presença de bolhas e de "rechupes".

Os corpos-de-prova de tração de PEAD branco apresentaram um comportamento bastante uniforme, pois atingiram a elongação prescrita pela ASTM D638-03, deformando até o final do cursor da máquina universal de ensaios. Entretanto, os corpos-de-prova de coloração verde apresentaram ruptura bastante distinta, figura 6.12, fato comprovado pelo elevado valor do desvio padrão. 


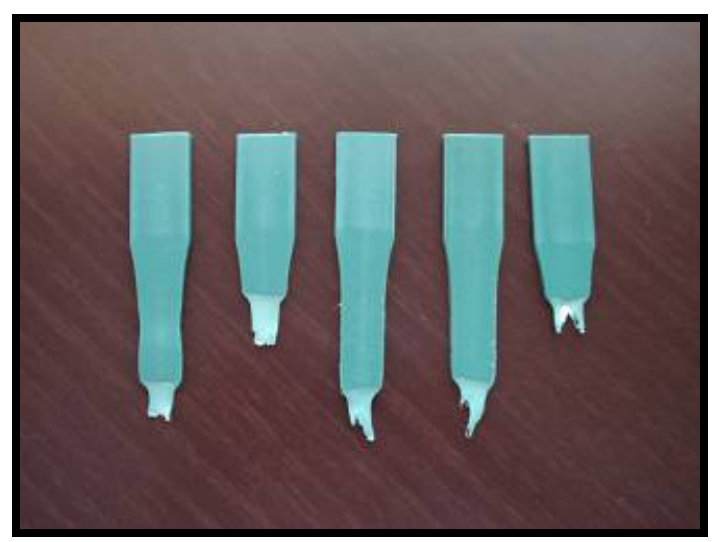

Figura 6.12: Ruptura dos corpos-de-prova de tração de PEAD verde.

\subsection{2- Utilização do PEAD em elementos estruturais}

Devido ao concreto armado ainda ser o material estrutural mais empregado na construção civil, ele foi escolhido como parâmetro, a fim de comparar algumas de suas propriedades mecânicas com as propriedades do polietileno de alta densidade reciclado. A madeira foi outro material estrutural escolhido como parâmetro, já que entre os materiais estruturais empregados na construção civil, ela é o que mais se aproxima dos polímeros. Além disso, o material polimérico é uma nova alternativa para o campo de aplicações estruturais da madeira, como mourões, cruzetas, dormentes, etc.

Tabela 6.9: Valores médios do PEAD, do concreto e da madeira.

\begin{tabular}{|c|c|c|}
\hline Material & $\begin{array}{l}\text { Resistência à compressão } \\
(\mathrm{MPa})\end{array}$ & $\begin{array}{l}\text { Módulo de Elasticidade } \\
\text { (MPa) }\end{array}$ \\
\hline PEAD virgem & $17^{(i)}$ & $1040^{(i i)}$ \\
\hline PEAD reciclado branco & 26,20 & 805 \\
\hline Concreto & $32^{\text {(iii) }}$ & $23800^{\text {(iv) }}$ \\
\hline $\begin{array}{l}\text { Madeira Eucalyptus } \\
\text { Grandis }\end{array}$ & 40,3 & $12813^{(v)}$ \\
\hline \multicolumn{3}{|c|}{ (i) Fonte: www.planetaplastico.com.br/litera/prop_fisicas. } \\
\hline \multicolumn{3}{|c|}{$\begin{array}{l}\text { (ii) Módulo de elasticidade à flexão. Fonte: http://www.ipq.com.br/index.php?secao= } \\
\text { catalogo\&resina=pead\&processo=9\&produto }=10 \text {. }\end{array}$} \\
\hline \multicolumn{3}{|c|}{ (iii) Concreto Classe C25 e desvio padrão de 4 MPa. Fonte: NBR 12655 (1996). } \\
\hline \multicolumn{3}{|c|}{${ }^{\text {(iv) }}$ Módulo de elasticidade secante $\left(\mathrm{Ec}=0,85\right.$ x 5600 fck $\left.{ }^{1 / 2}\right)$. Fonte: NBR 6118 (2003). } \\
\hline \multicolumn{3}{|c|}{ (v) Módulo de elasticidade à compressão. Fonte: NBR 7190 (1997). } \\
\hline
\end{tabular}


Já que a resistência à compressão do PEAD reciclado corresponde a $82 \%$ do valor relativo ao concreto e a $65 \%$ do correspondente à madeira, uma possível aplicação do PEAD reciclado seria em elementos estruturais robustos submetidos à compressão, como colunas para marinas. Porém, em relação ao módulo de elasticidade, o PEAD reciclado representa uma porcentagem muito pequena, com relação ao concreto e à madeira, portanto sua rigidez precisa ser majorada.

Essa deficiência pode ser aprimorada pela adição de cargas minerais e fibras de elevado módulo e resistência ou com a utilização de blendas poliméricas. Conforme apresentado na tabela 6.10, os materiais reforçados com fibras de vidro apresentam um módulo de elasticidade muito superior, quando comparados com os materiais sem reforço. Aumentando assim a rigidez e a resistência do PEAD, ele pode ser equiparado com os materiais estruturais empregados na construção civil. Na tabela 6.11, pode-se perceber também que a tensão à tração e à compressão é bastante maior para os materiais com reforço. Além disso, a incorporação de fibras poliméricas e cargas na matriz também promovem o aumento da estabilidade dimensional.

Tabela 6.10: Módulos de elasticidade típicos (à temperatura ambiente). Fonte: Marczak (2004).

\begin{tabular}{cc}
\hline Material & $\begin{array}{c}\text { Módulo de } \\
\text { Elasticidade } \\
(\mathbf{G P a})\end{array}$ \\
\hline Compostos grafite-epóxi & 280 \\
\hline Aço & 210 \\
\hline Alumínio & 70 \\
\hline Epóxi reforçado com fibra de vidro & 40 \\
\hline Poliéster reforçado com fibra de vidro & 14 \\
\hline Nylons reforçado com 30\% de fibra de vidro & 10 \\
\hline Acrílicos & 3,5 \\
\hline Resinas epóxi & 3,1 \\
\hline Policarbonato & 3,1 \\
\hline Acetal copolímero & 2,9 \\
\hline Polietileno de alto peso molecular & 0,7 \\
\hline
\end{tabular}


Tabela 6.11 - Valores médios de propriedades de alguns tipos de materiais. Fonte: Rocha (1990 apud Silva, 2003).

\begin{tabular}{ccc}
\hline Material & $\begin{array}{c}\text { Tensão à tração } \\
\text { na ruptura } \\
(\mathbf{M P a})\end{array}$ & $\begin{array}{c}\text { Tensão à } \\
\text { compressão na } \\
\text { ruptura (MPa) }\end{array}$ \\
\hline $\begin{array}{c}\text { Aço para construção } \\
\text { civil }\end{array}$ & $\geq 370$ & 370 \\
\hline Concreto & $1,5-3,5$ & $20-40$ \\
\hline $\begin{array}{c}\text { Plástico rígido não } \\
\text { reforçado }\end{array}$ & $10-150$ & $7-200$ \\
\hline Plásticos reforçados & $200-1000$ & $150-500$ \\
\hline
\end{tabular}

A incorporação de nervuras ou costelas de reforço são alternativas que podem contribuir no aumento da rigidez e da resistência do PEAD (Dalfré, 2007). Porém deve-se ter cuidado com as espessuras das costelas de reforço, pois, conforme discutido anteriormente, a extrusão do PEAD é indicada apenas para perfis de paredes finas, por ele ter baixa rigidez e um processo de resfriamento muito lento.

Finalizando, deve ser ressaltado que este trabalho e o desenvolvido por Dalfré (2007), "Cruzetas de polímeros reciclados: caracterização dos materiais, análise numérica e ensaios de modelos reduzidos", são os primeiros trabalhos com caráter experimental realizados na Linha de Pesquisa "Elementos estruturais de polímeros reciclados", recentemente iniciada no Departamento de Engenharia de Estruturas da EESC-USP. Tiveram como objetivo subsidiar os próximos trabalhos que serão desenvolvidos, estudando elementos e sistemas estruturais com PEAD, bem como a incorporação de reforços e cargas para aumento das propriedades mecânicas desse material. Como todo trabalho pioneiro, foram encontradas dificuldades, apontadas ao longo deste texto, para auxiliar no desenvolvimento dos novos trabalhos. 


\section{CONCLUSÕES}

Este capítulo apresenta as conclusões do trabalho, bem como algumas sugestões para pesquisas futuras, para melhor compreensão das propriedades mecânicas do PEAD reciclado e avaliação do emprego de PEAD reciclado em elementos estruturais.

\section{1- ENSAIO DE BEILSTEIN}

Todas as amostras, branca, azul, vermelha, marrom e verde, não possuem contaminação com poli (cloreto de vinila) (PVC), fato comprovado pela permanência da coloração amarela da chama, no ensaio de Beilstein.

\section{2- CALORIMETRIA EXPLORATÓRIA DIFERENCIAL}

Constatou-se que os materiais reciclados, fornecidos pela Reciclagem Nova Ribeirão, não diferem muito entre si, mesmo possuindo coloração bastante distinta, pois todas as amostras são isentas dos contaminantes comumente encontrados nos materiais reciclados, como PET e PP. Esse fato foi comprovado pela presença de um único pico de fusão, na curva de DSC. Além disso, as curvas de DSC são muito parecidas para todas as amostras ensaiadas, indicando que as amostras são homogêneas e semelhantes.

\section{3- TERMOGRAVIMETRIA}

Pode-se comprovar também, por meio do ensaio de TG, que as amostras de coloração verde e branca são, respectivamente, constituídas de $98,23 \%$ e $96,94 \%$ de polietileno de alta densidade, constatando que o PEAD reciclado, fornecido pela empresa de Ribeirão Preto, é praticamente puro. A porcentagem de resíduos inorgânicos, que não é significativa, pode corresponder à pigmentação inorgânica ou algum aditivo. 


\section{4- EXTRUSÃO DOS CORPOS-DE-PROVA}

As dificuldades encontradas no processamento do PEAD foram as principais responsáveis pelas diferenças das propriedades mecânicas entre o PEAD puro e o reciclado. As maiores dificuldades encontradas, durante o processamento do PEAD, podem ter sido decorrentes de: utilização de PEAD para moldagem a sopro, presença de umidade nos péletes e rosca não apropriada para o material empregado. Portanto, com material e equipamento adequados, a porosidade deverá diminuir e poder-se-á usar temperatura menor na moldagem dos perfis, tornando o resfriando mais rápido e evitando a ocorrência de "rechupes", provenientes de uma cristalização não uniforme.

\section{5- USINAGEM DOS CORPOS-DE-PROVA}

A escolha dos equipamentos bem como a usinagem dos corpos-de-prova, propriamente dita, foram conduzidas de modo a não alterar as propriedades do material, seguindo os padrões normativos.

Houve uma pequena variação nas dimensões dos corpos-de-prova obtidos da extrusão. Essa variação poderia ser amenizada usinando-os superficialmente. Porém, devido à porosidade apresentada na superfície do corte, descartou-se esta opção.

\section{6- PROPRIEDADES MECÂNICAS}

$\mathrm{O}$ PEAD reciclado possui um comportamento dúctil quando submetido à tração e à compressão. Devido a esse comportamento quando ensaiado à tração, ele apresenta características típicas do material virgem, baixo módulo de elasticidade, baixa tensão de escoamento, porém elevada elongação. Além disso, apresenta o comportamento de estiramento a frio. Porém a tensão à tração na ruptura do corpo-de-prova é inferior à tensão à tração no escoamento, devido a sua orientação molecular não ser intensa.

Como o material não rompeu até a deformação máxima permitida, 5\%, no ensaio de flexão, a resistência obtida corresponde a essa deformação.

O PEAD reciclado apresentou resistência ao impacto Izod muito próximo ao valor obtido na referência, para o PEAD puro. Comprovando que a resistência ao impacto não foi influenciada 
pelas inúmeras variáveis que geralmente interferem no ensaio de impacto. Todos os corpos-deprova ensaiados resultaram em ruptura completa.

O módulo de elasticidade do PEAD branco foi maior que o do verde, para os ensaios de tração, de compressão e de flexão, pois nesses ensaios o módulo aumenta com o grau de cristalinidade. Entretanto, a resistência ao impacto tem o comportamento oposto, por isso que o PEAD branco apresentou menor valor de energia de impacto quando comparado ao PEAD verde.

A resistência à compressão do PEAD reciclado não é muito pequena, quando comparada com a resistência do concreto e da madeira. Por isso, uma possível aplicação do PEAD seria em elementos estruturais robustos, submetidos à compressão. Porém, em relação à rigidez, o PEAD reciclado apresenta resultados muito pequenos, quando comparados aos materiais estruturais geralmente empregados na construção civil. Essa deficiência pode ser minorada pela adição de cargas minerais e de fibras de elevado módulo e resistência ou com a utilização de blendas poliméricas. Essas providências devem aumentar, também, a resistência à tração e à compressão. 


\section{REFERÊNCIAS BIBLIOGRÁFICAS}

AGNELLI, J.A.M. (2005). Introdução a materiais poliméricos. Engenharia de Materiais DEMa, UFSCar, São Carlos - SP. Notas de aula.

AGNELLI, J.A.M. (2005). Verbetes em polímeros. Engenharia de Materiais - DEMa, UFSCar, São Carlos - SP. Notas de aula.

AMIPP: GROUP MEMBERS: High Performance Marine Materials for the Coastal Infrastructure. Disponível em: < www.amipp.rutgers.edu/html/group_member_lynch.html $>$. Acesso em 11 Mai 2006.

AMIPP: GROUP MEMBERS: The New Jersey Shore - Rebuilding the Coastal Infraestructure. Disponível em: < www.amipp.rutgers.edu/html/group_member_lynch.html >. Acesso em 11 Mai 2006.

AMIPP: GROUP MEMBERS: The New Jersey Shore - Structural Polymer Composites from Recycled Raw Materials. Disponível em: <www.amipp.rutgers.edu/html/ groupmemberlynch.html>. Acesso em 11 Mai 2006.

ÁREA DE OPERAÇÕES INDUSTRIAIS 1 - AO1 - GERÊNCIA SETORIAL DO COMPLEXO QUÍMICO RELATO SETORIAL: Polietileno de alta densidade (PEAD). Disponível em: $<$ www.bndes.gov.br/conhecimento/relato/peadx.pdf $>$. Acesso em 12 Fev 2006.

ASSOCIAÇÃO BRASILEIRA DE NORMAS TÉCNICAS (1994). NBR 13230: Reciclabilidade e identificação de materiais plásticos. Rio de Janeiro.

ASSOCIAÇÃO BRASILEIRA DE NORMAS TÉCNICAS (1996). NBR 12655: Concreto Preparo, controle e recebimento. Rio de Janeiro.

ASSOCIAÇÃO BRASILEIRA DE NORMAS TÉCNICAS (1997). NBR 7190: Projeto de Estruturas de Madeira. Rio de Janeiro.

ASSOCIAÇÃO BRASILEIRA DE NORMAS TÉCNICAS (2003). NB 6118: Projeto de estruturas de concreto - Procedimento. Rio de Janeiro.

AMERICAN SOCIETY FOR TESTING AND MATERIALS (1994). D5592-94: Standard guide for material properties needed in engineering design using plastics;

(1996). D638-96: Standard Test Method for Tensile Properties of Plastics;

(1999). D3417-99: Standard Test Method for Enthalpies of Fusion and Crystallization of Polymers by Differential Scanning Calorimetry (DSC);

(1999). D3418-99: Standard Test Method for Transition Temperatures of Polymers by Differential Scanning Calorimetry;

(2000). D5033-00: Standard Guide for Development of ASTM Standards Relating to Recycling and Use of Recycled Plastics; 
(2002). D695-02a: Standard Test Method for Compressive Properties of Rigid Plastics;

(2003). D638-03: Standard Test Method for Tensile Properties of Plastics;

(2003). D790-03: Standard Test Methods for Flexural Properties of Unreinforced and Reinforced Plastics and Electrical Insulating Materials;

(2004). D256-04: Standard Test Methods for Determining the Izod Pendulum Impact Resistance of Plastics;

AZOM.COM: Composites: A basic introduction to composite materials. Disponível em: $<$ www.azom.com/details.asp >. Acesso em 08 Fev 2006.

BERNAL, C.; BOLDARINI, A.; BREVIGLIERI, S.T.; CAVALHEIRO, E.T.G. (2002). Influência de alguns parâmetros experimentais nos resultados de análises calorimétricas diferenciais - DSC. Quim. Nova, v.25, n.5, 849-855, 2002. Disponível em: <quimicanova.sbq.org.br/qnol/2002/vol25n5/22.pdf>. Acesso em 16 Mar 2006.

BLASS, A. (1985). Processamento de polímeros. Florianópolis: Editora da UFSC.

CANEVAROLO, S.V.Jr (2004). Técnicas de Caracterização de Polímeros. Editora Artliber ABPol. São Paulo.

CARASCHI, J. C.; LEÃO, A. L. (2002). Avaliação das propriedades mecânicas dos plásticos reciclados provenientes de resíduos sólidos urbanos. Acta Scientiarum, Maringá, v.24, n.6, p.1599-1602, 2002. Disponível em: www.ppg.uem.br/docs/ctf/Tecnologia/2002/02_156_02_ Jose\%20Caraschi_Avaliacao\%20das\%20propriedades.pdf>. Acesso em 15 Jul 2007.

CEMPRE - Compromisso Empresarial para Reciclagem. Plástico filme - O mercado para reciclagem. Disponível em: <www.cempre.org.br/fichas_tecnicas_plastico_filme.php $>$. Acesso em 3 Abr 2006.

COUTINHO, F.M.B.; MELLO, I.L.; MARIA, L.C.S. (2003). Polietileno: principais tipos, propriedades e aplicações. Polímeros v.13 n.1 São Carlos. Jan./ Mar. 2003. Instituto de Química, UERJ.

CRAWFORD, R.J. (1987). Plastics engineering. 2nd Edition. Belfast: Pergamon Press.

DALFRÉ, G.M. (2007). Cruzetas de Polímeros Reciclados: Caracterização dos Materiais, Análise Numérica e Ensaios de Modelos Reduzidos. Dissertação (Mestrado). Engenharia de Estruturas - SET/EESC/USP, São Carlos - SP.

DESENVOLVIMENTO - Ministério do Desenvolvimento, Indústria e Comércio Exterior: Transformados plásticos. Disponível em: <http:/www.desenvolvimento.gov.br/arquivo/sdp/ proAcao/forCompetitividade/impZonLivComercio/23transformadosPlasticosResumo.pdf $>$.

Acesso em 23 Jan 2006.

EFUNDA - Engineering Fundamentals: Introduction to Composite Materials. Disponível em: < www.efunda.com/formulae/solid_mechanics/composites>. Acesso em 08 Fev 2006. 
EMIC - Equipamentos e Sistemas de Ensaio Ltda (2007). Manual EEPA para linha DL (Digital Line). Departamento de Assistência Técnica, São José dos Pinhais, Paraná.

FERRAROLI, F.; MOTTA, I. (2001). Uma nova dimensão dos termoplásticos: o consumo energético. Polímeros, Jul./Set. 2001, v.11, n.3, p.12-13. ISSN 0104-1428.

GORNI, A.A. (2006). Siderúrgicas são o novo espaço para reciclagem energética de plásticos pós-consumo. Plástico Industrial; Aranda editor; ano VIII n.89, p.84-100, jan 2006.

GORNI, A.A. Revista Plástico Industrial. Disponível em: <www.gorni.eng.br /intropol.html >. Acesso em 06 Fev 2006.

GUTERMAN, L. (2003). One world: plastics - a group of researches defies wisdom with polymer blends. The Chronicle of Higher Education, 28 Fevereiro 2003.

HAMADA, J. (2003). Resíduos Sólidos: Conceituação e Caracterização. Faculdade de Engenharia de Bauru - SP, GERESOL UNESP.

HOLLAWAY, L. (1993). Polymer composites for civil and structural engineering. Blackie Academic \& Professional, an imprint of Chapman \& Hall, Wester Cleddens Road, Bishopbriggs, Glasgow G64 2 NZ.

HOLLAWAY, L. C. (2003). The evolution of and the way forward for advanced polymer composites in the civil infrastructure. Disponível em: $<\mathrm{http}: / / \mathrm{www}$.sciencedirect.com $>$. Acesso em 31 Jan 2006.

INTERNATIONAL ASSOCIATION OF PLASTICS DISTRIBUTORS - IAPD: How plastics are made. Disponível em: < www.modernplastics.com/pdf/IAPD_plastics_intro1.pdf $>$. Acesso em 16 Jan 2006.

International Organization for Standardization. ISO 527-1 Test Standard. Plastics - Determination of tensile properties - Part 1: General principles.

IONASHIRO, M.; GIOLITO, I. (s.d.). Nomenclatura, padrões e apresentação dos resultados em análise térmica. Instituto de Química da Universidade de São Paulo, São Paulo, SP, Brasil.

IONASHIRO, M.; GIOLITO, I. (s.d.). A nomenclatura em análise térmica - Parte II. Instituto de Química da Universidade de São Paulo e Instituto de Química da Universidade Estadual Paulista de Araraquara, SP.

MANO, E.B., MENDES, L.C. (2000). Identificação de Plásticos, Borrachas e Fibras. Editora Edgard Blucher Ltda.

MARCZAK, R. J. (2004). Polímeros como Materiais de Engenharia. Porto Alegre.

NIELSEN, L.E.; LANDEL, R.F. (1994). Mechanical Properties of Polymers and Composites. $2^{\text {nd }}$ edition.

PARENTE, R.A. (2006). Elementos estruturais de plástico reciclado. Dissertação (Mestrado). Engenharia Estruturas - SET/EESC/USP, São Carlos - SP. 
POLITENO: Uma empresa de classe mundial. Disponível em: < www.jorplast. com.br/secoes/aulas-5.htm>. Acesso em 31 Jan 2006.

RECICLAGEM MECÂNICA DO PVC: Uma Oportunidade de Negócio - Folder reciclagem. Instituto do PVC e Universidade de São Paulo - USP. Disponível em: <www.institutodopvc. org/reciclagem.htm>. Acesso em 03 Abr 2006.

REINFORCED PLASTICS: ASSET bridge in place. Disponível em: < www. reinforcedplastics.com/market_focus/construction/Asset_bridge.html>. Acesso em 16 Mai 2006.

SCHUT, J.H. (2004). They've been working on the railroad. Disponível em: $<\mathrm{http} / / /$ www.plastictechnology.com/article/200404fa3.html>. Acesso em 04 Fev 2005.

SETTING UP A PLASTICS RECYCLING BUSINESS. Disponível em: $<$ www1.sac.ac.uk/info/External/Publications/WasteRecycling/Chapter7-SettingupaPlastics Recycling Business.pdf $>$. Acesso em 3 Abr 2006.

SILVA, J.F.R. (2003). Cruzetas para redes de distribuição de energia elétrica à base de polipropileno. Dissertação (Mestrado). Engenharia Elétrica - SEL/EESC/USP, São Carlos - SP.

SILVA, R.V. (2003). Compósito de resina poliuretano derivada de óleo de mamona e fibras vegetais. Tese (Doutorado). Ciência e Engenharia de Materiais - SEM/EESC/USP, São Carlos SP.

SÍTIO DO INSTITUTO AVANÇADO DO PLÁSTICO - IAP. Disponível em: $<$ www.planetaplastico.com.br/pe.htm>. Acesso em 12 Fev 2006.

Site eletrônico da empresa Incomplast, Brasil. Disponível em: < www.incomplast.com.br/ f_poliet.htm>. Acesso em 15 Mar 2007.

Site eletrônico do Jornal de Plásticos, Brasil. Disponível em: < www.jorplast.com.br/jpfev07/ pag00.htm>. Acesso em 26 Set 2007.

Site eletrônico da empresa Ipiranga Petroquímica, Brasil. Disponível em: < http:// www.ipq.com.br/index.php? secao $=$ catalogo\&resina $=$ pead\&processo $=9 \&$ produto $=10>. \quad$ Acesso em 26 Set 2007.

SPINACÉ, M.A.S., PAOLI, M.A. (2005). A tecnologia da reciclagem de polímeros. Quím. Nova, v.28, n.1. São Paulo Jan./Feb. 2005. Disponível em: <www.scielo.br/scielo.php?pid= S000-40422005000100014\& script=sci_arttext >. Acesso em 03 Abr 2006.

SOUSA, J.A. (2005). Propriedades de Engenharia de Termoplásticos. Engenharia de Materiais DEMa, UFSCar, São Carlos - SP. Notas de aula.

SOUSA, J.A.; HAGE, JR.E. (2005). Compósitos Termoplásticos. Engenharia de Materiais DEMa, UFSCar, São Carlos - SP.

SUllivaN, H.W.; WOLFGANG, A.M.(1999). Polymeric compositions and methods for making construction materials from them. United States Patent. Patent Number: 5.886.078. 23 Mar 1999. 
VALSANI, F. (1988). Polietileno: 30 anos de Brasil. São Paulo, Rios.

WIKIPEDIA: Beilstein test. Disponível em: <en.wikipedia.org/wiki/Beilstein_test-10k>. Acesso em 14 Fev 2006. 


\section{CARACTERIZAÇÃO DOS POLÍMEROS RECICLADOS}

Por meio de testes é possível determinar as propriedades, a composição e o desempenho dos materiais poliméricos. Com a diversificação dos plásticos em aplicações de engenharia, as técnicas para caracterização dos polímeros tiveram um grande avanço nos últimos 15 anos.

\section{A.1- ENSAIO DE BEILSTEIN}

Este teste químico foi desenvolvido por Friedrich Konrad Beilsten, e consiste de uma maneira simples e rápida para determinar a presença de halogênios (cloro, bromo ou iodo) nos polímeros, permitindo preservar os equipamentos de TG e de DSC de danos que podem ser causados pela volatilização de componentes corrosivos.

O procedimento do ensaio de Beilstein consiste em preparar um fio elétrico de cobre, sem a capa de isolamento, com aproximadamente $5 \mathrm{~cm}$ de comprimento, e aquecê-lo em chama de bico de Bunsen até se torná-lo "rubro", com uma chama permanentemente amarela (figura A.1). Após tocar a superfície da amostra com o fio de cobre, este deve ser levado novamente à chama, que deverá ter a sua coloração detectada.

A formação de uma chama de coloração azul ou verde indica a presença de cloreto, brometo ou iodeto de cobre na amostra. A distinção entre eles se dá pela coloração da chama ou por meio de reações químicas. Como o intuito deste trabalho é apenas identificar a presença de halogênio e não diferenciá-los, não será necessário distinguir a coloração da chama ou realizar outro ensaio para diferenciar os tipos de halogênios.

Atualmente o ensaio de Beilstein não é muito utilizado devido à possível geração de dióxido de cloro, que é altamente tóxico, caso o resultado do teste seja positivo. Um ensaio alternativo para a identificação de halogênios é o ensaio de fusão de sódio. Porém, diversas universidades têm proibido a realização deste ensaio, devido à grande quantidade de incêndios 
gerados, pois ele somente é seguro quando realizado com pequena quantidade de sódio, (Wikipedia, 2006).

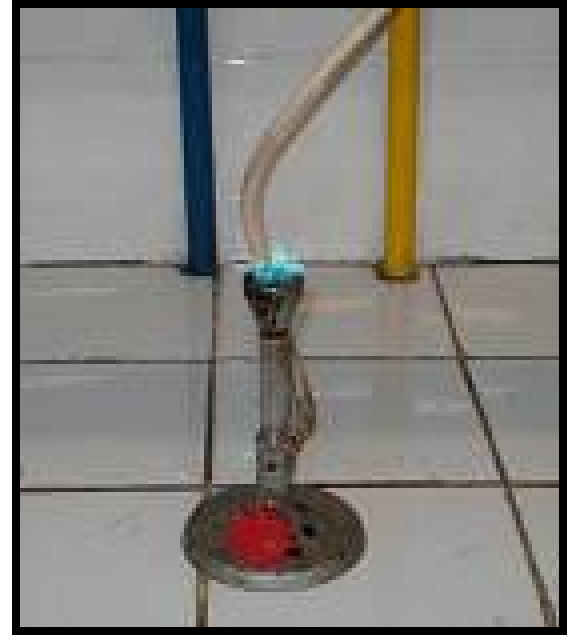

(a)

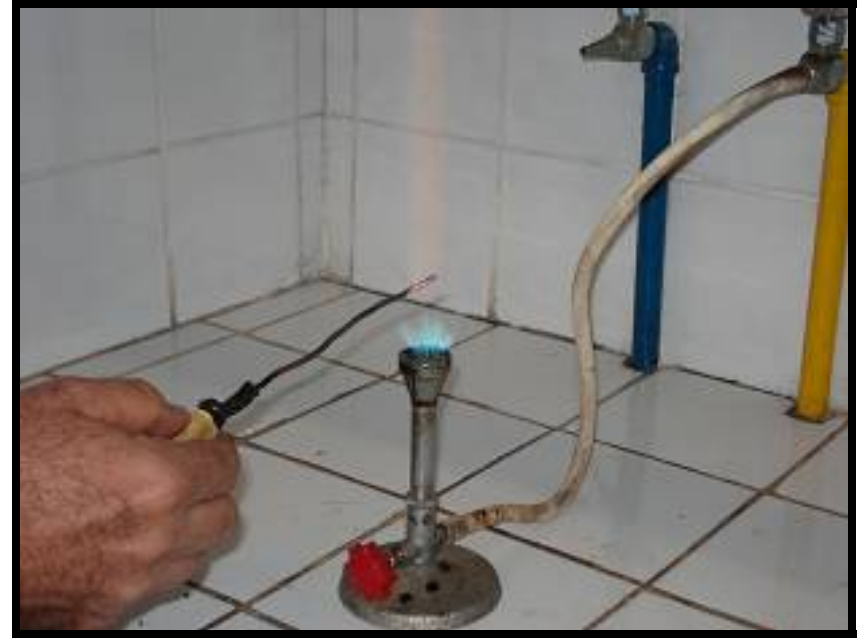

(b)

Figura A.1: Ensaio de Beilstein: (a) bico de bunsen; (b) chama amarela.

\section{A.2- ANÁLISES TÉRMICAS}

Em 1992, o Comitê de Nomenclatura da Confederação Internacional de Análise Térmica (ICTAC) estabeleceu toda a nomenclatura utilizada em análise térmica. No Brasil, o órgão responsável pela tradução dos termos técnicos, de acordo com as instruções da ICTAC, é a Associação Brasileira de Análise Térmica e Calorimetria (ABRATEC), que também segue as recomendações da IUPAC e da ASTM (Ionashiro, s.d.).

A análise térmica consiste em um grupo de métodos para determinar uma propriedade física de uma substância e/ou de seus produtos de reação, em função da temperatura, enquanto a amostra é submetida a um programa de temperatura controlado. Esse programa de temperatura pode envolver aquecimento ou resfriamento (dinâmico), manter a temperatura constante (isotérmica), ou pode ser uma combinação deles.

A classificação dos métodos termoanalíticos é baseada na propriedade física a ser determinada em função da temperatura. A tabela A.1 lista a técnica utilizada, em função da propriedade física a ser medida. 
Tabela A.1: Classificação das principais técnicas termoanalíticas. Fonte: Giolito* (1998 apud Canevarolo, 2004).

\begin{tabular}{ccc}
\hline Propriedade Física & Principais Técnicas & Abreviatura \\
\hline \multirow{3}{*}{ Massa } & Termogravimetria & TG \\
\cline { 2 - 3 } & Detecção de gás desprendido & EGD \\
\cline { 2 - 3 } & Análise de gás desprendido & EGA \\
\cline { 2 - 3 } & Análise térmica por emanação & ETA \\
\cline { 2 - 3 } Temperatura & Determinação da curva de aquecimento & \\
\cline { 2 - 3 } & Análise térmica diferencial & DTA \\
\hline Entalpia & Terimetria exploratória diferencial & DSC \\
\hline Dimensões & Análise termomecânica & TD \\
\hline \multirow{2}{*}{ Características mecânicas } & TMA \\
\cline { 2 - 3 } Características acústicas & Análise termomecânica dinâmica & DMA \\
\cline { 2 - 3 } & Termossonimetria & TS \\
\hline Características ópticas & Termoacustimetria & TO \\
\hline Emissão de luz & Termoptometria & TL \\
\hline Características elétricas & Termoluminescência & TE \\
\hline Características magnéticas & Termoeletrometria & TM \\
\hline
\end{tabular}

A análise térmica é uma técnica muito utilizada em vários ramos da ciência e da tecnologia. As informações básicas, fornecidas por essas técnicas, como grau de cristalinidade, calor específico, estabilidade térmica, composição de materiais, etc., são parâmetros importantíssimos para pesquisas e para desenvolvimento de novos produtos. As técnicas de análise térmica também são muito empregadas para controle de qualidade, devido às exigências de um mundo cada vez mais competitivo.

Outra vantagem da análise térmica é que pode ser empregada em vários tipos de materiais poliméricos, como blendas, compósitos, aditivos, revestimentos, adesivos, elastômeros, termorrígidos e termoplásticos.

As técnicas de análises térmica mais empregadas na caracterização de materiais são: termogravimetria (TG); análise térmica diferencial (DTA); calorimetria exploratória diferencial (DSC); análise termomecânica (TMA); análise dinâmico-mecânica (DMA) e análise dinâmicodielétrica (DEA) (Canevarolo, 2004).

\footnotetext{
* GIOLITO, I. Revista de Química Industrial. 663, 12, 1988.
} 


\section{A.2.1- Calorimetria Exploratória Diferencial}

A determinação do calor de fusão e de cristalização em polímeros é regida pela ASTM D 3417 (99): Standard Test Method for Enthalpies of Fusion and Crystallization of Polymers by Differential Scanning Calorimetry (DSC). Essa norma é similar, mas não equivale às normas da ISO: 11357-1 e 11357-3. A norma da ASTM que rege a determinação da temperatura de transição em polímeros é a ASTM D 3418 (99) Standard Test Method for Transition Temperatures of Polymers by Differential Scanning Calorimetry. Essa norma é similar às respectivas normas da ISO: 11357-1 e 11357-2.

A calorimetria exploratória diferencial, também conhecida por calorimetria diferencial de varredura, é uma das técnicas de análise térmica que têm sido largamente empregadas na caracterização de diversos tipos de materiais. O termo DSC foi utilizado primeiramente em 1963 para definir um sistema desenvolvido pela empresa norte-americana Perkin-Elmer, (Bernal et al., 2002).

A calorimetria exploratória diferencial consiste em medir a diferença de energia fornecida a uma substância que está sendo analisada e a um material de referência, em um programa de temperatura controlado, ambos em função da temperatura.

Existem duas modalidades, que são dadas de acordo com o método de medição utilizado: a calorimetria exploratória diferencial com compensação de potência e a calorimetria exploratória diferencial com fluxo de calor.

A calorimetria exploratória diferencial com compensação de potência consiste em um calorímetro, que mede diretamente a energia envolvida nos eventos térmicos, sendo que a amostra e a referência são aquecidas ou resfriadas em fornos separados, porém idênticos, ambos mantidos a temperatura constante. Caso a amostra sofra alterações de temperatura promovidas por um evento, endotérmico ou exotérmico, os termopares detectam a diferença de temperatura entre ela e a referência, com o equipamento modificando automaticamente a potência de entrada de um dos fornos, a fim de igualar prontamente a temperatura de ambos.

Já a calorimetria exploratória diferencial, com fluxo de calor, mede a diferença de temperatura entre a amostra e a referência, sendo ambas aquecidas pela mesma fonte de calor. 
Nesta técnica, a amostra e o material de referência são dispostos em cápsulas idênticas, sobre um disco termoelétrico, que transfere o calor para as cápsulas por meio de um fluxo de calor diferencial. Esse fluxo é medido por meio de termopares que são conectados ao disco, obtendo um sinal proporcional à diferença de capacidade térmica entre a amostra e a referência.

Está ilustrado na figura A.2 um exemplo de equipamento genérico para calorimetria exploratória diferencial e sua classificação em função da cela utilizada.

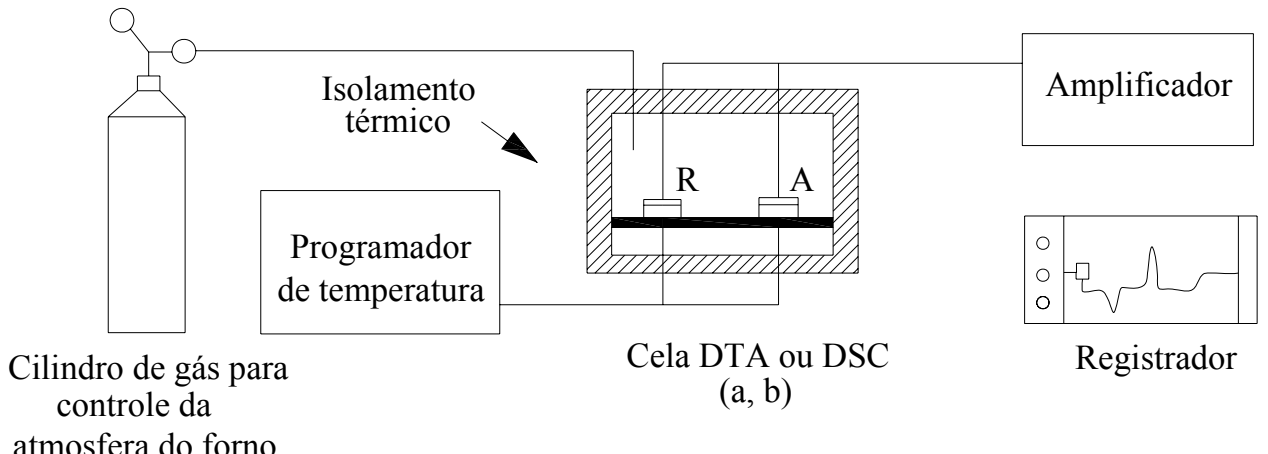

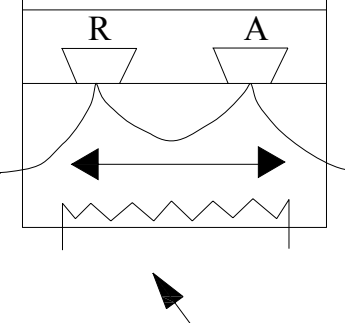

Aquecedor elétrico

(a)

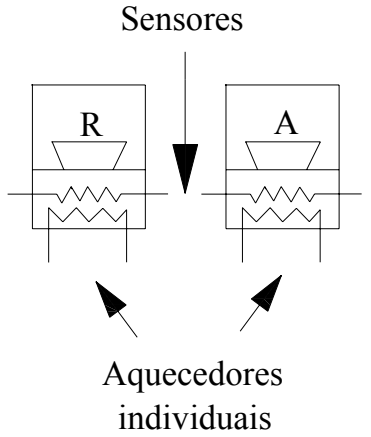

(b)

Figura A.2: Esquema de um equipamento genérico para calorimetria exploratória diferencial (DSC):

(a) com fluxo de calor; (b) DSC com compensação de potência. Fonte: Bernal (2002).

Para obter o grau de cristalinidade do PEAD reciclado, utiliza-se o calor de fusão do PEAD 100\% hipoteticamente cristalino, 293 J/g (Canevarolo 2004 apud, Kaisersberger ${ }^{*}, 1994$; Mettler ${ }^{*}$, s.d.), conforme a relação A.1.

\footnotetext{
*KAISERSBERGER, E.; MOHLER, H.; KNAPPE, S.; RAHNER, S.; "NETSCH Annual for Science and Industry", Selb Wurzburg, vol.3, 1994.
} 


$$
\chi=\frac{\Delta H_{f}}{\Delta H_{f}^{\circ}} \times 100
$$

$\Delta \mathrm{H}_{\mathrm{f}}$ e $\Delta \mathrm{H}_{\mathrm{f}}{ }^{\mathrm{o}}$ são, respectivamente, o calor de fusão da amostra e o calor de fusão do polímero hipoteticamente $100 \%$ cristalino, expressos em J/g.

Os resultados experimentais podem ser influenciados por dois tipos de fatores: os instrumentais e os relacionados às características da amostra. Os principais fatores instrumentais que afetam as curvas de DSC são: razão (ou taxa) de aquecimento, atmosfera do forno, tipo de gás fluente, condutividade térmica do gás de arraste, tipo de cápsula, material da cápsula, entre outros

O procedimento de ensaio consiste em:

- $\quad$ Pesar dois cadinhos, um de referência e outro para colocar a amostra, em torno de $29,7 \mathrm{mg}$, valor este definido em função do equipamento utilizado;

- Preparar uma quantidade de 5 a $10 \mathrm{mg}$ de amostra, em cadinho de alumínio puro, com uma precisão de $0,01 \mathrm{mg}$. Utiliza-se alumínio puro para não contaminar a amostra, pois sua fusão ocorre em tono de $660^{\circ} \mathrm{C}$, distante da faixa de temperatura usualmente escolhida para realização do ensaio;

- $\quad$ Aquecer a amostra desde a temperatura ambiente até em torno de $300^{\circ} \mathrm{C}$, com uma taxa de aquecimento de $10^{\circ} \mathrm{C} / \mathrm{min}$. Essa faixa de temperatura é escolhida em função de varrer a temperatura de fusão dos possíveis contaminantes, que podem estar contidos nas amostras;

- Sujeitar a amostra a uma atmosfera de gás nitrogênio super seco, com vazão contínua de $15 \mathrm{~N}$, a fim de manter constante a composição da atmosfera do forno. Nesse ensaio a vazão foi fornecida na unidade de $\mathrm{N}$, pois ela foi medida por meio de um manômetro, já que o equipamento utilizado não era provido de fluxômetro. Porém, na maioria dos equipamentos de DSC, a vazão varia entre 10 a $50 \mathrm{~mL} / \mathrm{min} \pm 5 \%$.

\footnotetext{
" METTLER TOLEDO - "Collectec Applications TA - Thermoplastics", s/d.
} 


\section{A.2.2- Termogravimetria}

A análise termogravimétrica, no campo de materiais poliméricos, vem sendo largamente empregada desde a década de 60 , no desenvolvimento de diversos tipos de estudos, relacionados à variação de massa, em função do tempo ou da temperatura (Canevarolo, 2004).

Existem três modos diferentes, utilizados na termogravimetria:

- Termogravimetria isotérmica: a massa da amostra é registrada em função do tempo, com temperatura constante;

- Termogravimetria quase-isotérmica: a amostra é aquecida a uma taxa de aquecimento linear enquanto não houver variação de massa; após este momento, a temperatura é mantida constante até obter um novo patamar, ou seja, massa constante;

- Termogravimetria dinâmica ou convencional: a amostra é submetida a um programa de temperatura pré-determinado, sendo linear a razão de aquecimento ou de resfriamento.

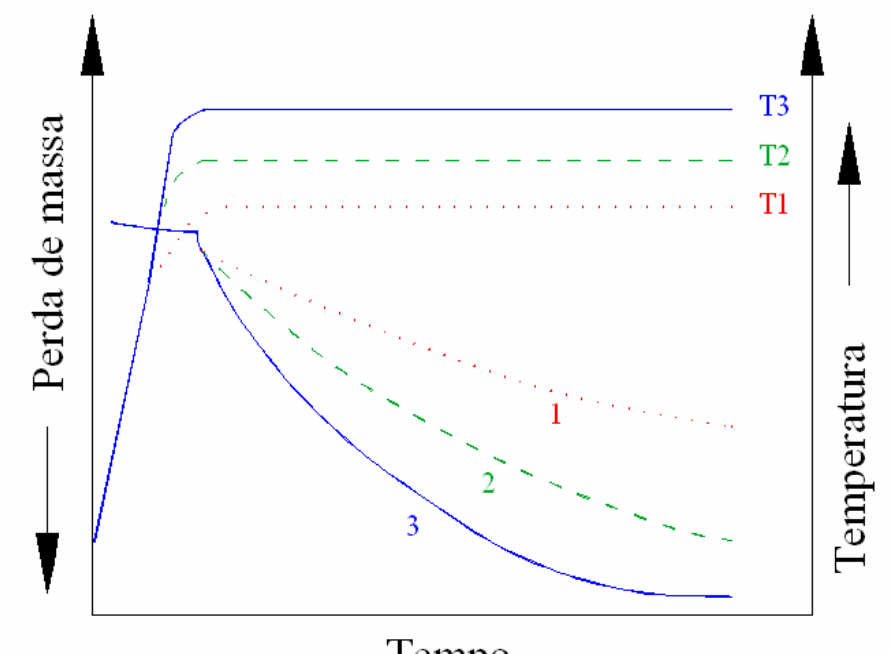

Tempo

(a) 


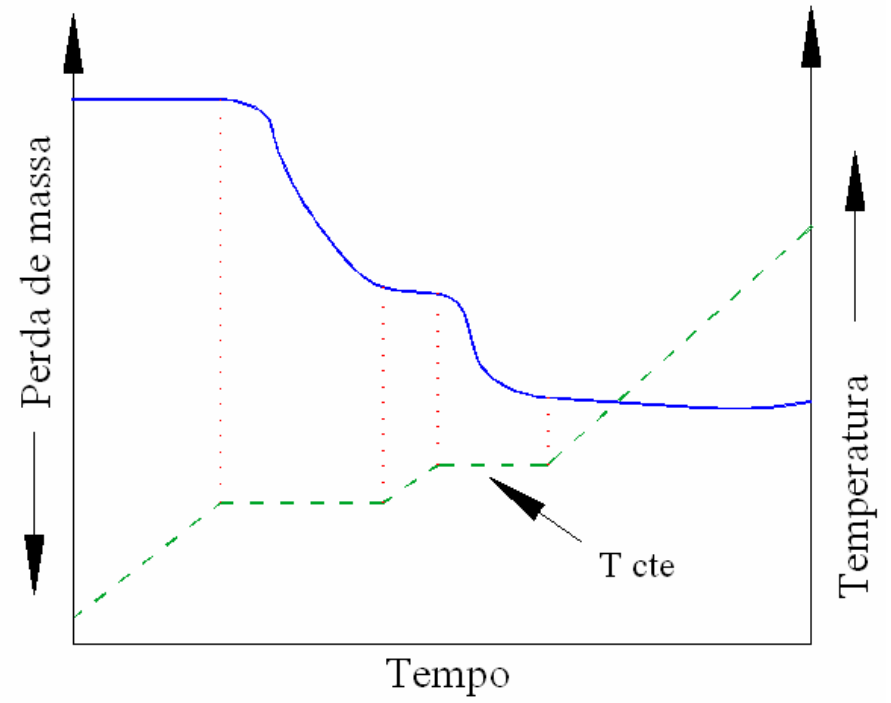

(b)

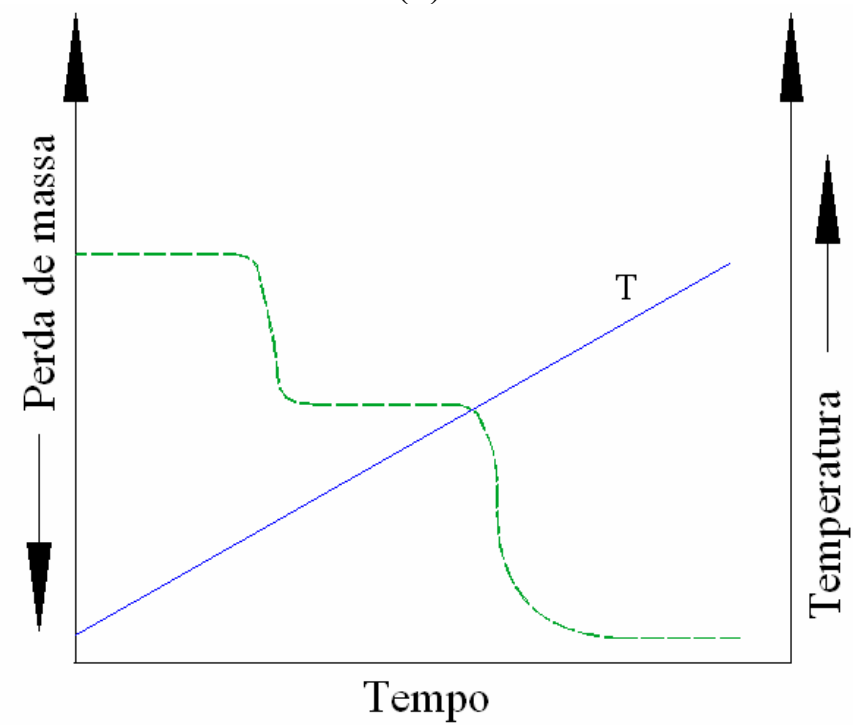

(c)

Figura A.3: Três modos de termogravimetria. a) TG isotérmica; b) TG quase-isotérmica; (c) TG dinâmica. Fonte: Canevarolo (2004).

As variações de massa, perda ou ganho, podem ser determinadas quantitativamente, embora outras variáveis sejam determinadas a partir da curva termogravimétrica gerada, pois as temperaturas dos eventos térmicos dependem de características da amostra e de parâmetros instrumentais.

As curvas termogravimétricas, também chamadas de curvas TG, são curvas de massa da amostra ensaiada, em função da temperatura ou do tempo (equação A.2). A massa e a 
temperatura podem ser representadas em função do tempo, a fim de verificar a taxa de aquecimento, porém isso não é muito usual, quando há a necessidade de comparar com outras curvas.

$$
\mathrm{m}^{\prime}=\mathrm{f}\left(\mathrm{T} \text { ou } \mathrm{t}^{\prime}\right)
$$

Ao aquecer uma amostra, ocorrem alterações devidas às reações de desidratação, oxidação, combustão, decomposição, etc., sendo que, por meio da análise termogravimétrica, é possível conhecê-las e estabelecer uma faixa de temperatura, ao se atingir um valor em que o material a ser analisado adquire composição química fixa e definida.

Conforme ilustra a figura A.4, a decomposição da maioria dos polímeros ocorre na faixa entre 200 e $450^{\circ} \mathrm{C}$. Devido ao PEAD ter alto peso molecular, sua decomposição ocorre numa temperatura mais elevada.

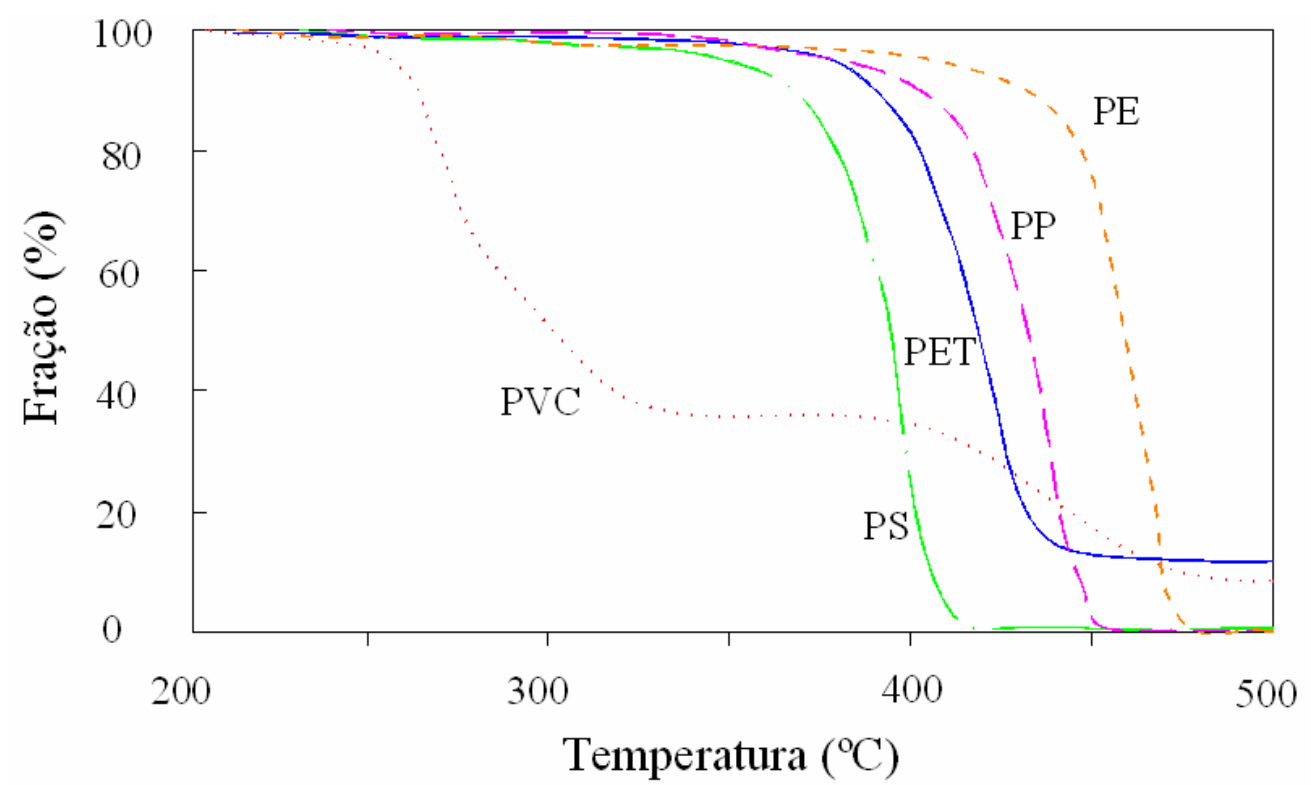

Figura A.4: Curvas de decomposição térmica para vários tipos de resinas plásticas. Fonte: Gorni (2006).

A temperatura de decomposição é dada pela termogravimetria derivada, DTG, expressa em \%/min. Essa curva representa a derivada primeira da variação de massa em função do tempo (dm/dt), registrada em relação ao tempo (Canevarolo, 2004). A curva DTG não contém mais informações do que a curva de TG, ela apenas apresenta os dados de forma mais fácil de visualizar. Outra vantagem de obter a DTG é verificar se houve reações sobrepostas, pois pode 
haver reações que ocorrem numa mesma faixa de temperatura, originando apenas uma perda de massa contínua ao invés de várias perdas, como ilustrado na figura A.5.

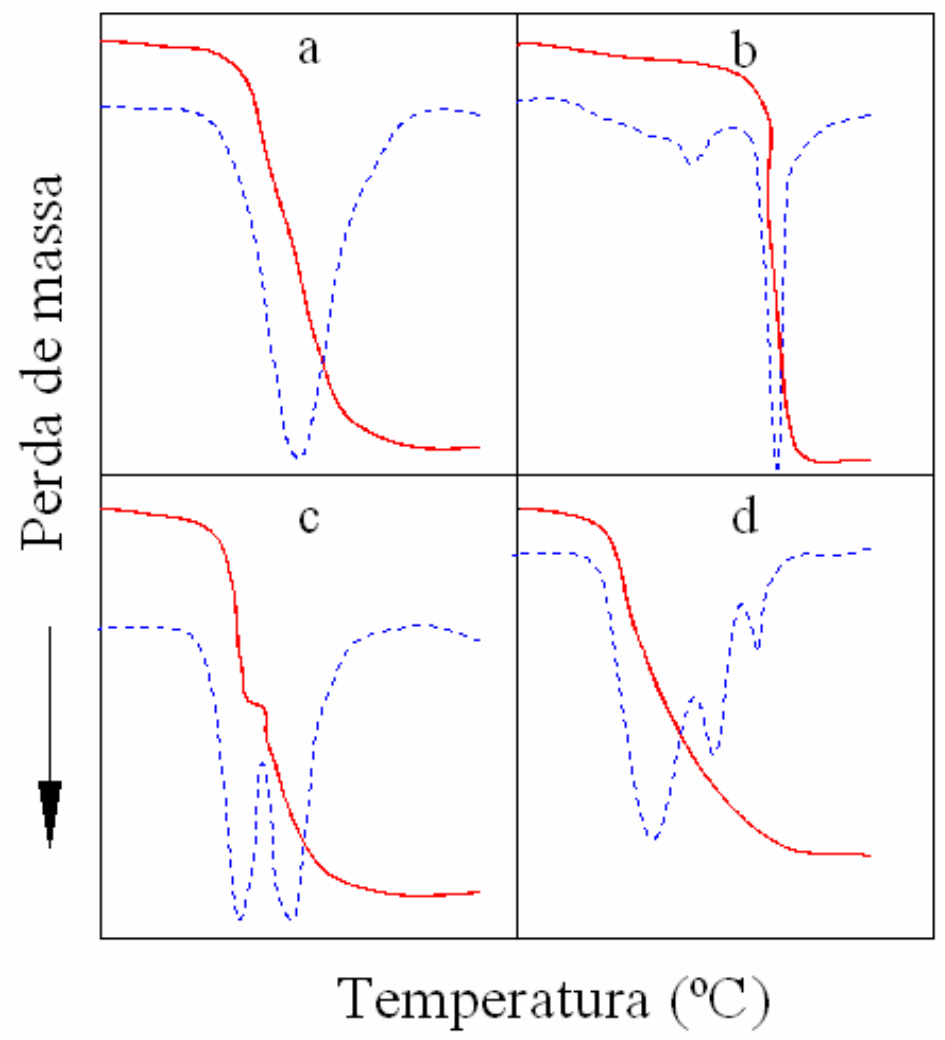

Figura A.5: Comparação de curvas TG/DTG. (b), (c) e (d) exibem reações sobrepostas.

Fonte: Canevarolo (2004).

Assim como no ensaio de DSC, existem fatores que podem interferir na curva de TG. Porém existem alguns fatores que podem afetar ou até mesmo invalidar o ensaio termogravimétrico, como: instabilidade da atmosfera no suporte de amostras, correntes de convecção e turbulência no forno, medida de temperatura e calibração, flutuações de temperatura, condensação no suporte da amostra, flutuações aleatórias no equipamento de registro e na balança, efeito de indução no forno, efeitos eletrostáticos no mecanismo da balança, calibração de massa.

O procedimento de ensaio consiste em:

- Preparar uma quantidade de 10 a $15 \mathrm{mg}$ de amostra, em cadinho de alumina, com uma precisão de $0,01 \mathrm{mg}$; 
- Aquecer a amostra em uma faixa desde a temperatura ambiente até uma temperatura máxima de $600^{\circ} \mathrm{C}$, com uma razão de aquecimento de $10^{\circ} \mathrm{C} / \mathrm{min}$. Essa faixa de temperatura é escolhida em função de varrer a temperatura de decomposição dos materiais poliméricos comumente encontrados nos materiais reciclados;

- Sujeitar a amostra a uma atmosfera dinâmica de nitrogênio, vazão de gás da ordem de $50 \mathrm{ml} / \mathrm{min}$, que por ser um gás inerte evita a oxidação do forno, além de ser mais estável para mensurar a massa da amostra, durante o ensaio.

\section{A.3- ENSAIOS MECÂNICOS}

Atualmente realizam-se ensaios mecânicos em corpos-de-prova, com o intuito de estabelecer as diversas classes de materiais poliméricos, avaliando qualitativamente e quantitativamente a viabilidade de uso. Além disso, podem-se sugerir aplicações para usos em estruturas, comparando com o desempenho de outros materiais, como madeira, concreto armado, entre outros.

Nos próximos itens serão apresentadas as principais particularidades dos ensaios de tração, de compressão e de flexão, que são muito usuais em engenharia de estruturas, além do ensaio de impacto Izod, que é importante para caracterizar os polímeros rígidos.

\section{A.3.1- Ensaio de Tração}

O procedimento da ASTM D 638 (03): Standard Test Method for Tensile Properties of Plastics, que é tecnicamente equivalente ao da norma ISO 527-1, é muito utilizado para a realização do ensaio de tração em polímeros. Por meio desse procedimento, é feita uma caracterização qualitativa e direcionada à pesquisa e ao desenvolvimento de novos materiais.

O objetivo principal desse ensaio é determinar a resistência no escoamento, obtida pela tensão no escoamento, e o módulo de elasticidade. Também é possível obter a deformação no escoamento, a tensão e deformação na ruptura, a elongação percentual e a tensão máxima. Para obter o módulo de elasticidade o ensaio deve ser conduzido à velocidade de $5 \mathrm{~mm} / \mathrm{min}$. Os demais parâmetro não têm essa exigência, e sim que o ensaio tenha menor duração, entre $1 / 2$ e 5 minutos. 
A escolha da velocidade depende do tipo de material e da geometria do corpo-de-prova, conforme a tabela 1 da norma consultada.

De acordo com a ASTM D 638 (03), os corpos-de-prova possuem geometria na forma de halteres. Com relação às dimensões, existem cinco tipos de corpos-de-prova para os plásticos rígidos e semi-rígidos, de modo que a escolha é dada em função do comportamento mecânico do polímero que será ensaiado (Dalfré 2007). O tipo I é preferível quando o corpo-de-prova possui uma espessura de $7 \mathrm{~mm}$ ou menos. O tipo II pode ser utilizado quando o material não rompe na seção delgada. O tipo III deve ser utilizado para todos os materiais com espessura maior ou igual a $7 \mathrm{~mm}$, mas não superior a $14 \mathrm{~mm}$. O tipo IV é utilizado quando se deseja comparar materiais com diferentes casos de rigidez. $\mathrm{O}$ tipo $\mathrm{V}$ deve utilizado quando o material tiver uma limitação de espessura de $4 \mathrm{~mm}$ ou menos ou quando se tem um grande número de corpos-de-prova a ser ensaiado (Parente, 2006).

Dependendo do comportamento do material, pode-se obter o módulo de elasticidade tangente ou secante. Quando um material tem um comportamento hookeano, ou seja, linear, obtém-se o módulo de elasticidade tangencial, que pode ser determinado em qualquer ponto ao longo da reta $\mathrm{CD}$, ilustrada na figura A.6. Ele é dado pelo coeficiente angular da reta tangente, traçada na parte linear da curva.

O ponto $\mathrm{B}$, dado pela intersecção da reta $\mathrm{CD}$ com o eixo de deformação, é considerado como ponto de deformação nula, a partir do qual são medidas as deformações. A tensão de escoamento deslocada é definida no ponto $\mathrm{F}$ (cruzamento da curva tensão $x$ deformação com a reta $\mathrm{EF}$, que está deslocada $1 \%$ paralelamente à reta $\mathrm{BD}$ ). Segundo as normas da ASTM, esse parâmetro não é exigido no ensaio de tração, ao contrário do ensaio de compressão. 


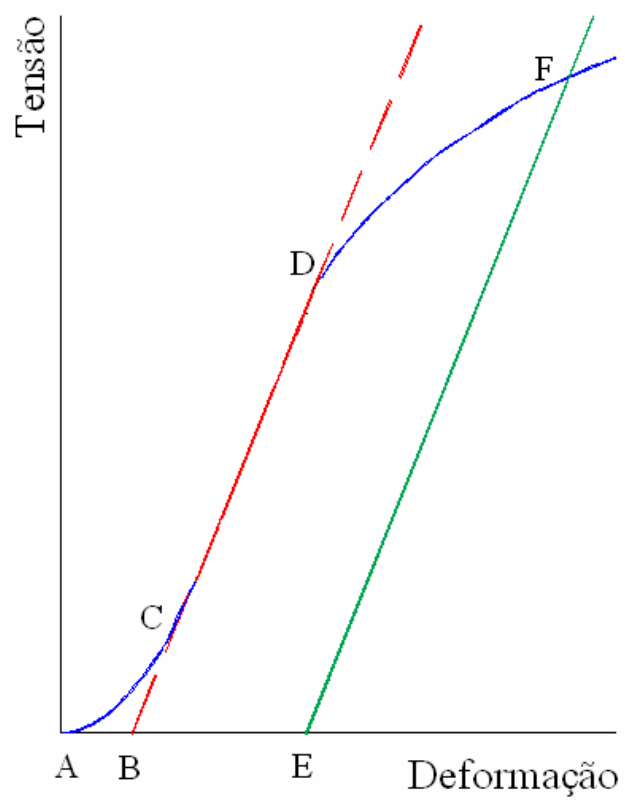

Figura A.6: Curva tensão-deformação para materiais com comportamento hookeano.

Fonte: ASTM D 638 - 03.

A tensão de escoamento é a tensão na qual o material mostra um desvio do limite de elasticidade. Se a tensão for máxima no ponto de escoamento, este termo será a resistência à tração no escoamento. A resistência é dada pela razão entre a máxima força suportada pelo corpo-de-prova e a área inicial da seção transversal.

O segmento $\mathrm{AC}$ da curva tensão $x$ deformação, ilustrada na figura A.6, corresponde ao ajuste inicial do equipamento e do corpo-de-prova, não representando alguma propriedade do material.

No caso de um material que não possuem comportamento hookeano, ilustrado na figura A.7, realiza-se o mesmo procedimento referente a um material que tenha o comportamento linear, traçando uma tangente na máxima inclinação do ponto de inflexão, obtendo-se a reta H'K'. Prolonga-se essa reta até o eixo de deformação, a fim de se obter o ponto B'. Porém o módulo obtido é o módulo secante, que é dado ao longo da reta B'G', ou seja, ligando o ponto B' ao ponto de escoamento, representado por G'. Ele é obtido por meio do cruzamento de uma paralela a reta $H^{\prime} K^{\prime}$ com a curva, a partir do ponto E', que é dado pela soma de $1 \%$ à deformação do ponto B'. 


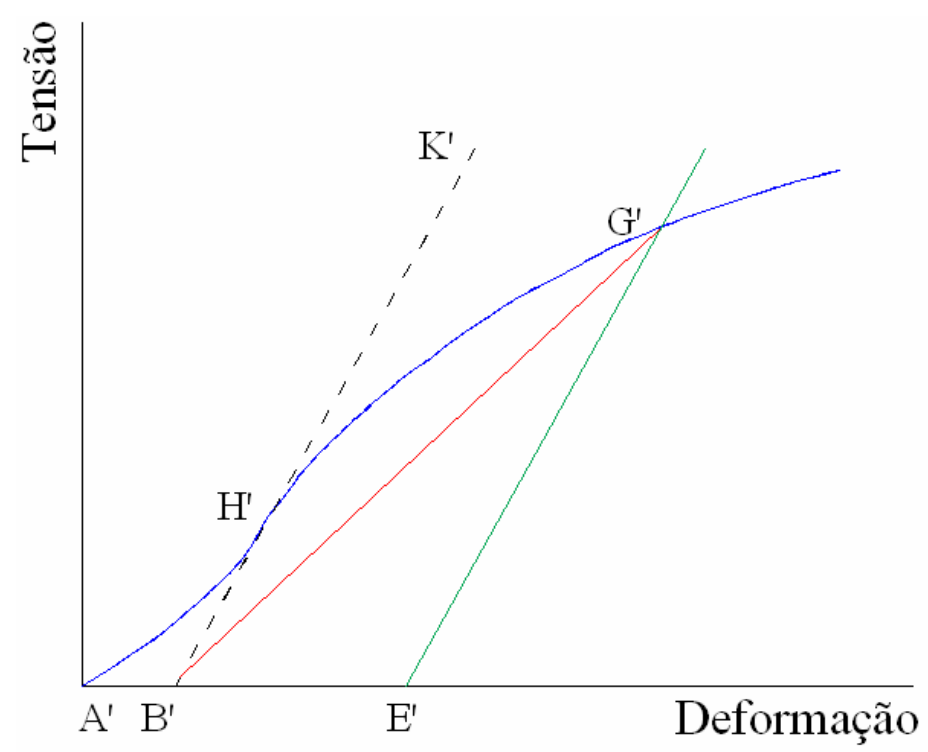

Figura A.7: Curva tensão-deformação para materiais com comportamento não-hookeano. Fonte: ASTM D 638 - 03.

\section{A.3.2- Ensaio de Compressão}

O procedimento da ASTM D 695 2(a): Standard Test Method for Compressive Properties of Rigid Plastics, que é tecnicamente equivalente ao da norma ISO 527-1, é muito utilizado para a realização do ensaio de compressão em polímeros.

O corpo-de-prova padronizado deve possuir a forma de um cilindro ou prisma reto, em que sua altura seja o dobro do diâmetro ou da largura principal. As dimensões mais usuais, segundo a ASTM D 695 2(a) são 12,7mm x 12,7mm x 25,4mm. Porém, quando se deseja obter o módulo de elasticidade e a tensão no ponto de escoamento, as dimensões recomendadas são $12,5 \mathrm{~mm} \times 12,5 \mathrm{~mm} \times 50,8 \mathrm{~mm}$.

O objetivo desse ensaio é determinar a resistência e o módulo de elasticidade. Esses parâmetros são dados como no ensaio de tração. Também é possível obter a tensão e a deformação no escoamento e a tensão de escoamento deslocada.

\section{A.3.3- Ensaio de Flexão}

O procedimento da ASTM D 790 (03): Standard Test Method for Flexural Properties of Unreinforced and Reinforced Plastics and Electrical Insulating Materials, que é tecnicamente 
equivalente ao da norma ISO 178, é muito utilizado para a realização do ensaio de flexão em polímeros. Essa norma da ASTM refere-se ao ensaio de três pontos. Existem dois procedimentos de ensaios, segundo a ASTM D 790 (03):

- $\quad$ Procedimento A - para materiais que quebram para pequenos deslocamentos. É utilizado para medir as propriedades de flexão, como módulo de elasticidade na flexão;

- $\quad$ Procedimento B - para materiais que suportam grandes deslocamentos durante o ensaio. É utilizado para medir somente a resistência à flexão.

O objetivo desse ensaio é determinar a resistência à flexão e o módulo de elasticidade na flexão.

As dimensões do corpo-de-prova utilizado no ensaio de flexão são relacionadas entre si e variam de acordo com o processo de fabricação. Nos materiais em forma de camada, as dimensões são dadas de acordo com a espessura. Para materiais com altura maior ou igual a $3,2 \mathrm{~mm}$ a largura deve ser de $12,5 \mathrm{~mm}$, e não deve exceder um quarto da distância entre os apoios. O comprimento é dado por dezesseis vezes a altura, de acordo com a posição do corpo-de-prova ensaiado, de lâmina ou de perfil. As dimensões mais utilizadas para materiais termoplásticos e termorrígidos são $12,5 \mathrm{~mm}$ de largura e $3,2 \mathrm{~mm}$ ou $6,4 \mathrm{~mm}$ de altura. A norma especifica dimensões preferenciais para os termofixos laminados e os compósitos reforçados de elevada resistência.

As superfícies dos suportes e o ponto de aplicação do carregamento devem ser arredondados, para evitar uma possível ruptura devido ao efeito concentrador de tensão. $\mathrm{O}$ raio mínimo das superfícies em contato com o corpo-de-prova é de 3,2mm para todos os corpos-deprova, e o raio máximo não pode ser maior do que quatro vezes a espessura dele, isto é, $12,8 \mathrm{~mm}$.

A velocidade de carregamento, expressa em $\mathrm{mm} / \mathrm{min}$, deve ser calculada conforme a equação A.3:

$$
R=\frac{Z \times L^{2}}{6 \times d}
$$


L e d são a distância entre os apoios e a altura do corpo-de-prova, respectivamente. $\mathrm{Z}$ representa a taxa de deformação na superfície oposta ao carregamento, $0,01 \mathrm{~mm} / \mathrm{mm} / \mathrm{min}$ para o procedimento A e $0,10 \mathrm{~mm} / \mathrm{mm} / \mathrm{min}$ para o procedimento B.

O ensaio é concluído quando a deformação máxima na superfície oposta ao carregamento do corpo-de-prova, representada por $\mathrm{r}$ na equação A.4, atinge $0,05 \mathrm{~mm} / \mathrm{mm}$, isto é, $5 \%$, ou na ruptura, quando ela ocorre antes de atingir esta deformação. A flecha pode ser calculada por meio da equação A.4.

$$
D=\frac{r \times L^{2}}{6 \times d}
$$

A resistência à flexão é igual à tensão máxima nas fibras externas de um corpo-de-prova de um polímero, no momento de ruptura.

Para os materiais com deformações pequenas, cuja tensão é proporcional à deformação até o ponto de ruptura, a resistência à flexão, expressa em $\mathrm{MPa}$, pode ser calculada pela equação A.5.

$$
\sigma_{f}=\frac{3 \times P \times L}{2 \times b \times d^{2}}
$$

"P" e "b" são a carga em um dado ponto da curva força $x$ deslocamento e a largura do corpo-de-prova, respectivamente.

O módulo de elasticidade tangente, expresso em MPa, é dado pela razão, dentro do limite elástico, entre a tensão e a deformação correspondente, representado pela equação A.6.

$$
E_{f}=\frac{L^{3} \times m}{4 \times b \times d^{3}}
$$

O valor $\mathrm{m}$ é igual a $\mathrm{P} / \Delta$, ou seja, é a inclinação da tangente dentro do limite elástico da curva força $x$ deslocamento, em N/mm.

O módulo secante no ensaio de flexão pode ser calculado pela equação A.6, sendo "m" a inclinação da secante da curva força $x$ deslocamento. 


\section{A.3.4- Ensaio de Impacto}

O procedimento da ASTM 256: Standard Test Method for Determining the Izod Pendulum Impact Resistence of Plastics é muito utilizado para a realização do ensaio de impacto, para os corpos-de-prova providos de entalhe. Existem quatro variantes bastante similares para realizar este ensaio (A, C, D e E), Izod, nas quais os equipamentos e as dimensões dos corpos-deprova são os mesmos. Existe um outro método "B", Charpy, que tem algumas variações em relação aos demais.

No método de ensaio A, impacto Izod, o corpo-de-prova é preso na extremidade inferior, na posição vertical, esquema de uma viga em balanço, sendo fraturado por um único giro de um pêndulo. A linha do contato inicial tem uma distância fixa da linha de centro do entalhe e ocorre na mesma face do entalhe.

$\mathrm{O}$ método de ensaio $\mathrm{C}$ é semelhante ao $\mathrm{A}$, porém há um procedimento para determinar a energia expandida em uma porção do corpo-de-prova. $\mathrm{O}$ método $\mathrm{C}$ é utilizado no lugar do método A, para materiais que têm resistência ao impacto menor do que $27 \mathrm{~J} / \mathrm{m}$.

O método de ensaio D mede a sensibilidade de um material ao entalhe. A concentração de tensão no entalhe aumenta quando o raio do entalhe diminui.

O método de ensaio E é similar ao A, porém o corpo-de-prova é ensaiado com o entalhe na face oposta.

O objetivo principal do ensaio de impacto é determinar a resistência à quebra por choques ou impactos de flexão. A resistência ao impacto é quantificada em termos da energia de impacto absorvida, por unidade de espessura ao longo do entalhe, ou pode ser expressa pela energia de impacto absorvida, dividida pela área da seção resistente do corpo-de-prova.

A largura mínima do corpo-de-prova para o ensaio de impacto deve ser dada de acordo com a especificação do material. Os corpos-de-prova moldados podem ter uma largura entre 3 e $12,5 \mathrm{~mm}$. Todos os corpos-de-prova que tiverem uma dimensão menor do que $12,5 \mathrm{~mm}$ devem ter o entalhe cortado no lado menor. Já aqueles moldados por compressão devem ter o entalhe no lado paralelo à direção de pressão de moldagem. 
Os parâmetros utilizados para realizar o entalhe não irão afetar o estado físico do material, desde que diminua sua temperatura de transição vítrea. A fim de evitar problemas térmicos, durante a execução do entalhe, deve-se utilizar velocidade de corte menor, velocidade de alimentação maior e usar colante, pois velocidades altas de alimentação e de corte causam fissuramento e impacto no corpo-de-prova. Os colantes mais adequados são água e gás comprimido.

O entalhe pode ser feito por meio de usinagem, e deve estar seguindo os padrões normativos. Os ângulos dos equipamentos para realizar o corte devem estar em torno de 15 a $20^{\circ}$. A velocidade para realizar o corte nos materiais termoplásticos deve variar entre 53 e $150 \mathrm{~mm} / \mathrm{min}$, já a velocidade de alimentação é em torno de 89 a $160 \mathrm{~mm} / \mathrm{min}$, quando não se utiliza água como colante, ao realizar o entalhe. Tanto a velocidade de alimentação como a de corte devem ser constantes ao longo da operação.

O ensaio inicia estimando-se a carga de ruptura e escolhendo um pêndulo mais adequado para a energia escolhida, ou seja, o pêndulo padrão mais leve possível, que quebre o corpo-deprova com perda de energia menor do que $85 \%$. O equipamento deve ser ajustado, caso ocorra excesso de atrito.

A ponta do pêndulo pode ser de aço, com uma superfície cilíndrica com raio de curvatura de $0,80 \pm 0,20 \mathrm{~mm}$ com seu eixo horizontal. O comprimento efetivo do pêndulo deve ser entre 0,33 e 0,40m. Portanto, a elevação requerida é conseguida levantando-o com um ângulo entre 30 e $60^{\circ}$ em relação à horizontal. A máquina deve ser provida de um pêndulo básico, capaz de liberar uma energia de 2,7 \pm 0,14J. Pêndulos com energia entre 2,7 a 21,7J são suficientes para os plásticos existentes. Geralmente são utilizados pêndulos mais duros em corpos-de-prova que requerem mais energia para ruptura. As garras fixas e móveis em contato com o corpo-de-prova devem ter um raio de $0,25 \pm 0,12 \mathrm{~mm}$.

O pêndulo, na posição vertical, cai de uma altura de $610 \pm 2 \mathrm{~mm}$, o que provoca uma velocidade de aproximadamente $3,5 \mathrm{~m} / \mathrm{s}$ no momento do impacto (equação A.7). Este mecanismo é construído e operado de modo a não provocar aceleração e vibração.

$$
V=(2 g h)^{0,5}
$$


A grandeza "g" é a aceleração da gravidade local e "h", a altura de queda do pêndulo.

A resistência ao impacto é quantificada em termos da energia de impacto dada em $\mathrm{J} / \mathrm{m}$, $\mathrm{kgf.cm} / \mathrm{cm}$ ou libras.pé/polegada de entalhe.

$$
\text { Energia }=\frac{W}{t}
$$

W e t são a energia de queda do corpo-de-prova entalhado e a espessura do corpo-deprova, respectivamente.

A resistência ao impacto Izod pode também ser fornecida em $\mathrm{J} / \mathrm{m}^{2}, \mathrm{kgf.cm} / \mathrm{cm}^{2}$ ou libras.pé/polegada ao quadrado (equação A.9).

$$
\text { Energia }=\frac{W}{t(b-c)}
$$

A dimensão "c" corresponde à profundidade do entalhe.

Um computador ou um mostrador eletrônico digital pode ser usado no lugar do marcador e do ponteiro, para medir a perda de energia e indicá-la no momento de ruptura do corpo-deprova.

A distância do eixo de suporte ao centro de percussão é determinada experimentalmente por meio de um período de uma pequena amplitude de oscilação, conforme a equação A.10.

$$
\ell=\frac{g \times p^{2}}{4 \pi^{2}}
$$

" $\ell$ " é a distância do eixo de suporte ao centro de percussão e "p", o período de um único giro completo, determinado pela média de pelo menos vinte giros consecutivos e ininterruptos.

O entalhe produz um efeito concentrador de tensão que aumenta a probabilidade de uma fratura frágil e não dúctil, direcionando-a para a região do corpo-de-prova atrás do entalhe. $\mathrm{O}$ tipo de ruptura para um dado corpo-de-prova pode ser dado de acordo com as quatro categorias listadas a seguir: 
- $\quad$ Ruptura completa: quando o corpo-de-prova se divide em dois ou mais pedaços;

- Ruptura articulada: é um tipo de ruptura incompleta, em que o corpo-de-prova não se divide, mas parte dele não se suporta, tendo um ângulo de abertura menor do que $90^{\circ}$.

- Ruptura parcial: consiste de uma ruptura incompleta, porém diferente da articulada. Sua fratura atinge pelo menos $90 \%$ da distância entre o entalhe e o seu lado oposto.

- Sem ruptura: é uma ruptura incompleta, em que a fratura atinge menos do que 90\% da distância entre o entalhe e seu lado oposto.

Nos materiais rígidos, o pêndulo pode não ter a energia necessária para completar a fratura das fibras externas, dividindo o corpo-de-prova em pedaços. Por esse motivo, os resultados obtidos dos corpos-de-prova que não apresentam uma ruptura, podem não representar um resultado padrão. 


\section{RESULTADOS OBTIDOS NOS ENSAIOS}

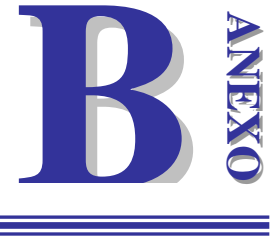

B.1- CALORIMETRIA EXPLORATÓRIA DIFERENCIAL

As curvas de DSC, obtidas para as cinco amostras de PEAD, estão ilustradas nas figuras B.1 a B.5.

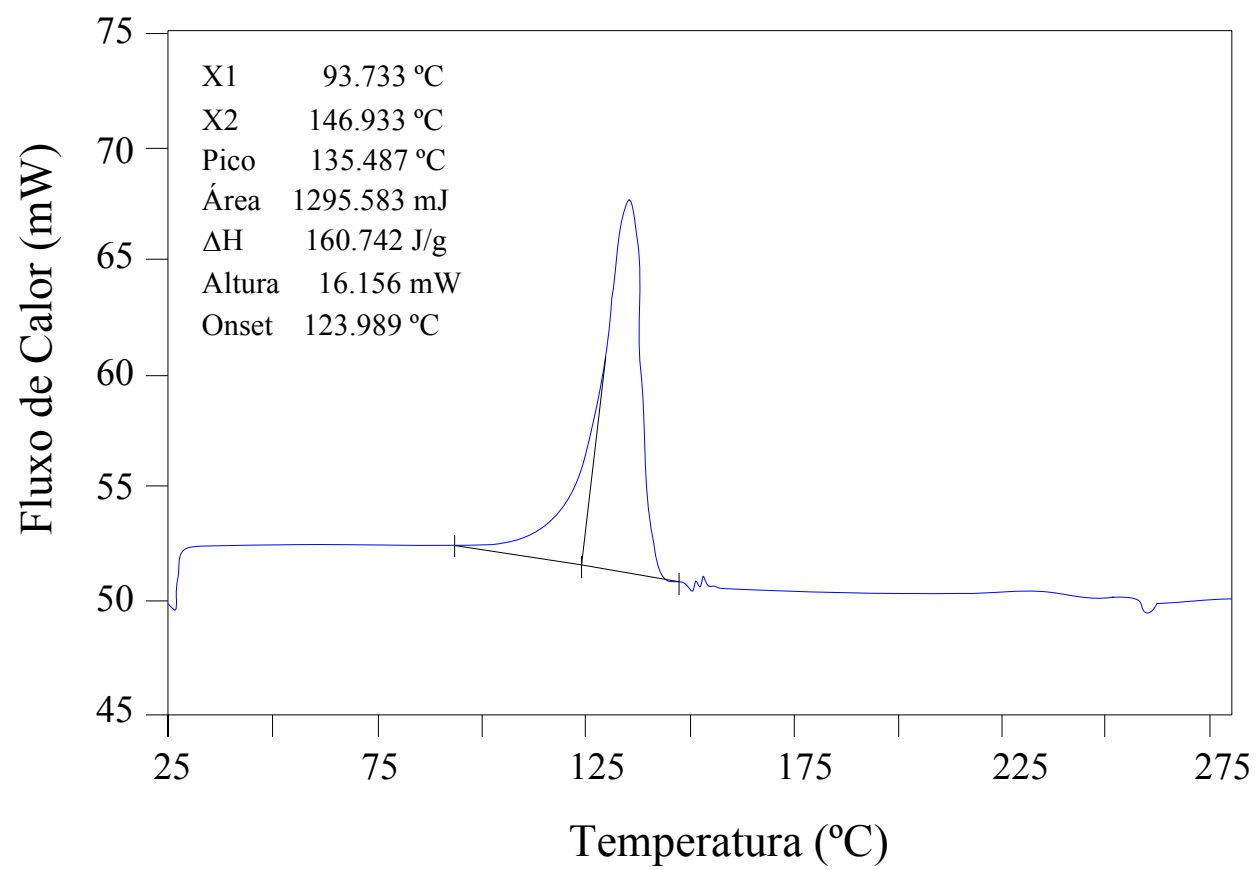

Figura B.1: Curva de DSC da amostra branca de PEAD. 


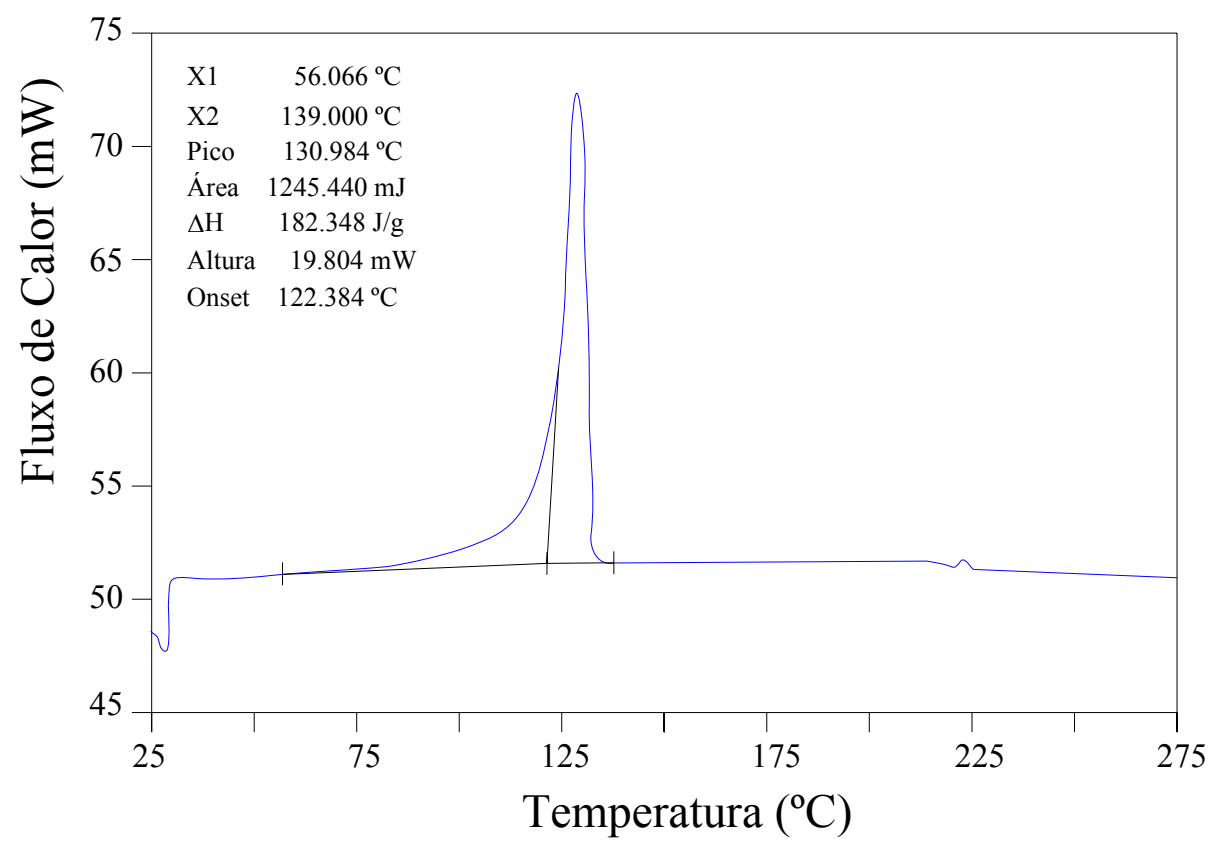

Figura B.2: Curva de DSC da amostra azul de PEAD.

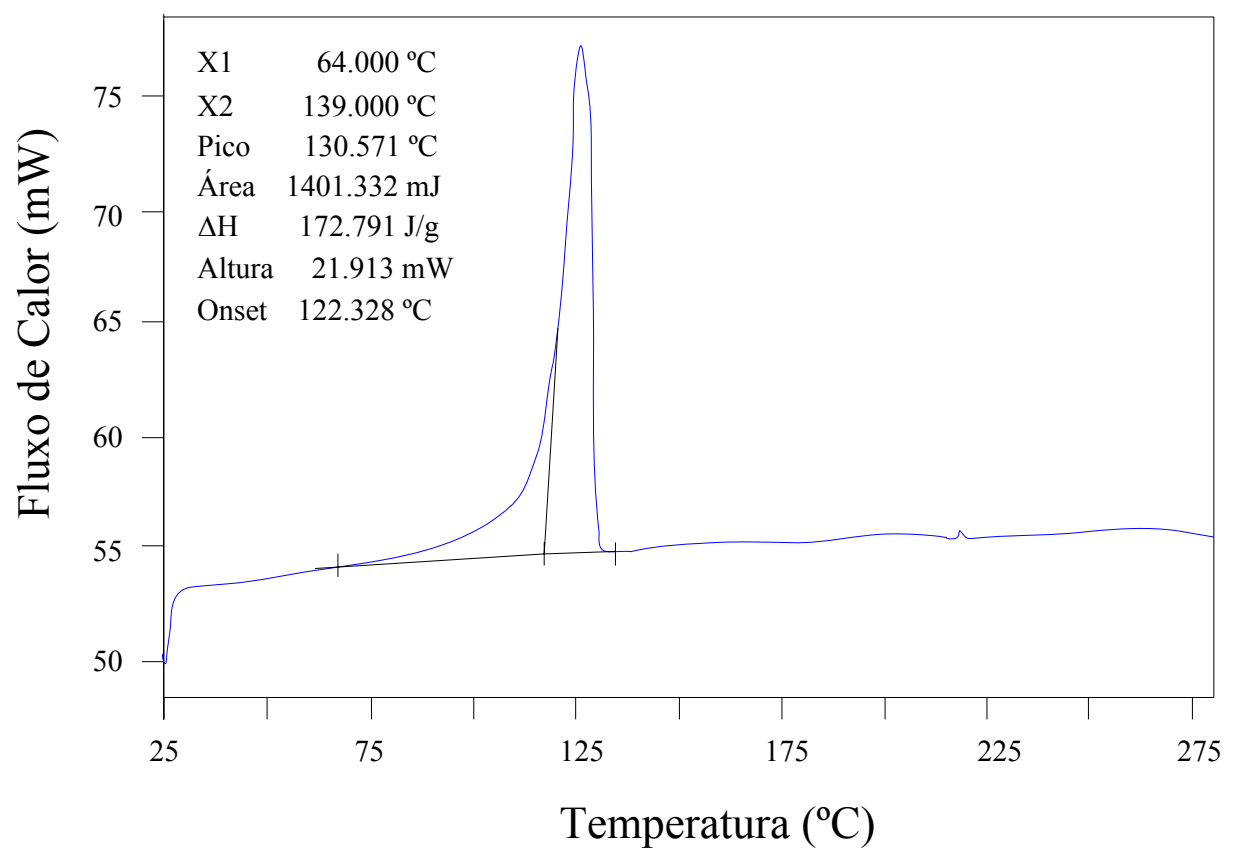

Figura B.3: Curva de DSC da amostra vermelha de PEAD. 


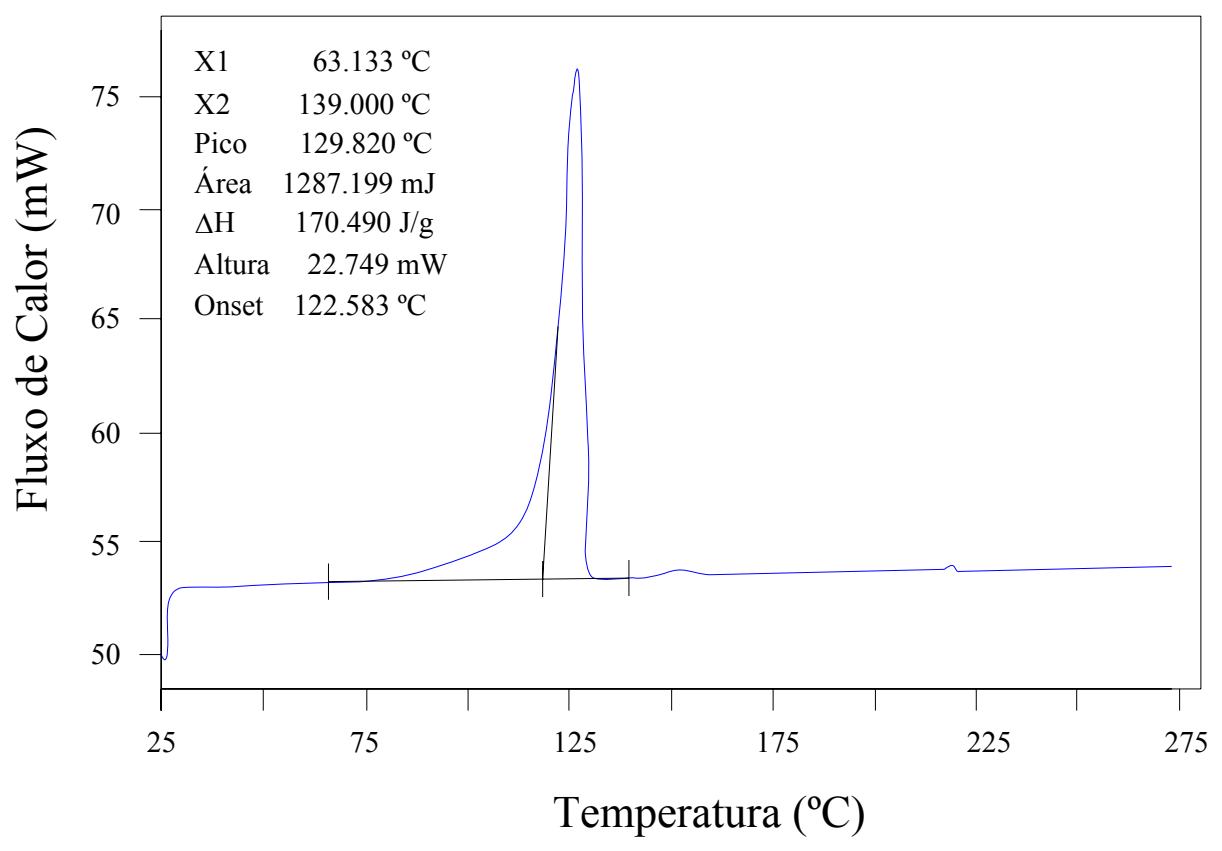

Figura B.4: Curva de DSC da amostra marrom de PEAD.

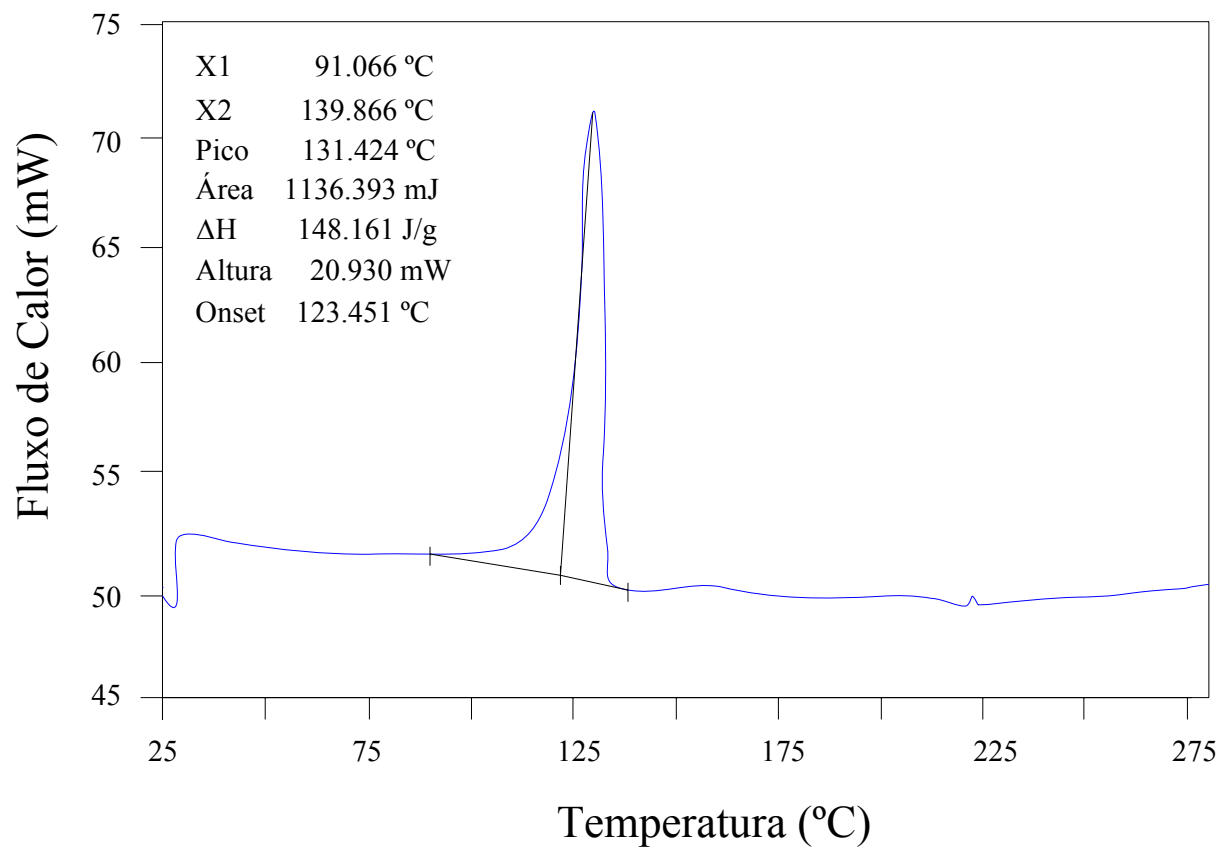

Figura B.5: Curva de DSC da amostra verde de PEAD. 


\section{B.2- ENSAIO DE TRAÇÃO}

As curvas tensão $x$ deformação obtidas para os cinco corpos-de-prova de PEAD, com colorações branca e verde, estão ilustradas nas figuras B.6 e B.7. Esses corpos-de-prova foram submetidos à velocidade de deslocamento de $5 \mathrm{~mm} / \mathrm{min}$, para obter o módulo de elasticidade, relativo ao coeficiente angular da reta vermelha.

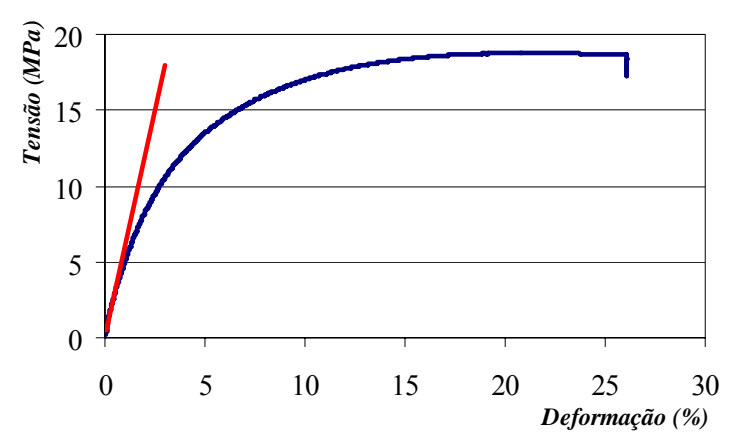

CP1

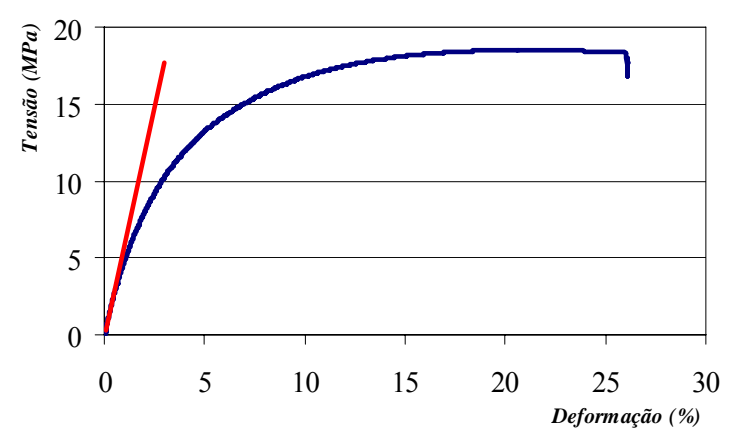

CP3

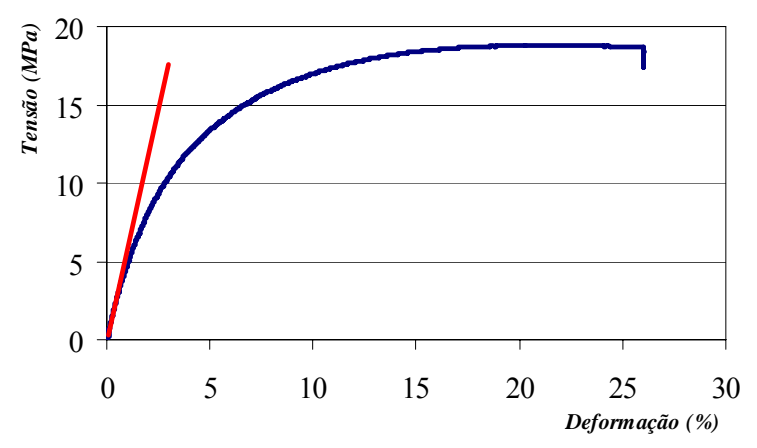

$\mathrm{CP} 2$

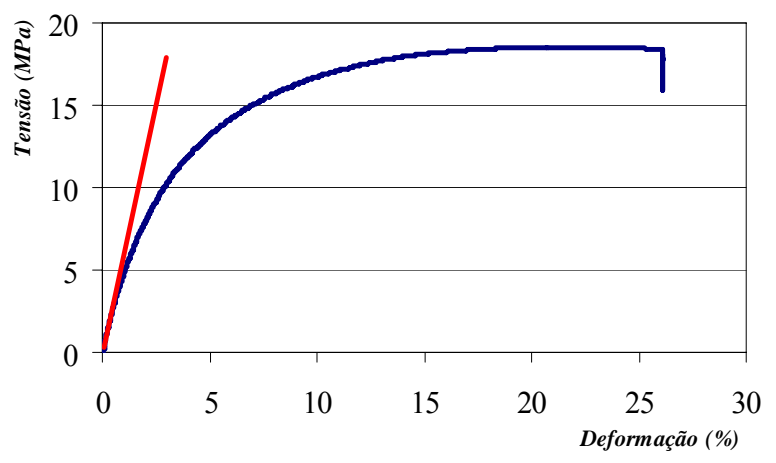

$\mathrm{CP} 4$

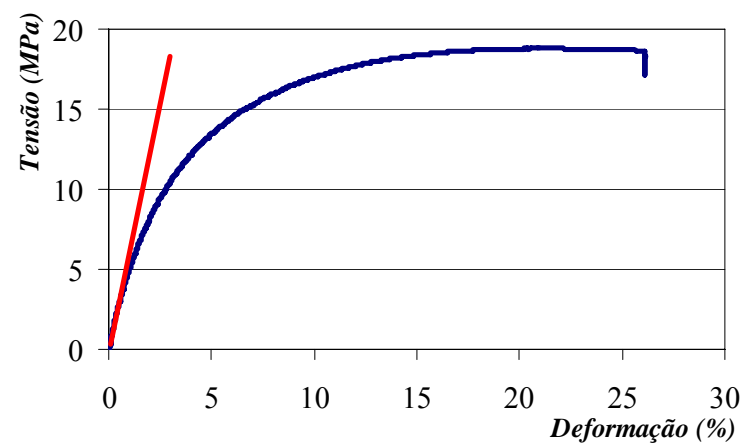

CP5

Figura B.6: Curvas tensão $x$ deformação obtidas para os corpos-de-prova de tração brancos, ensaiados com extensômetro. 


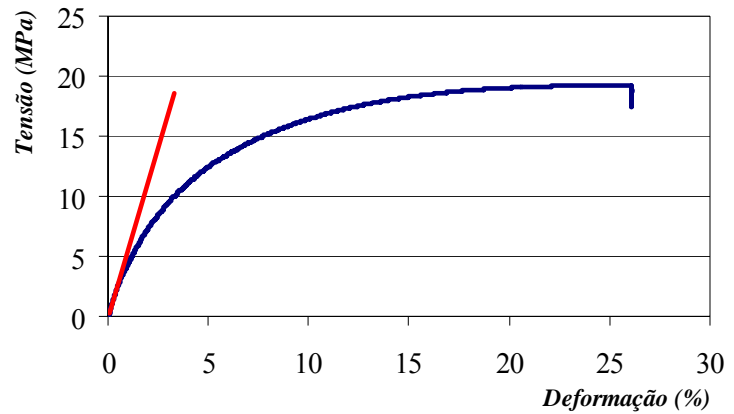

CP1

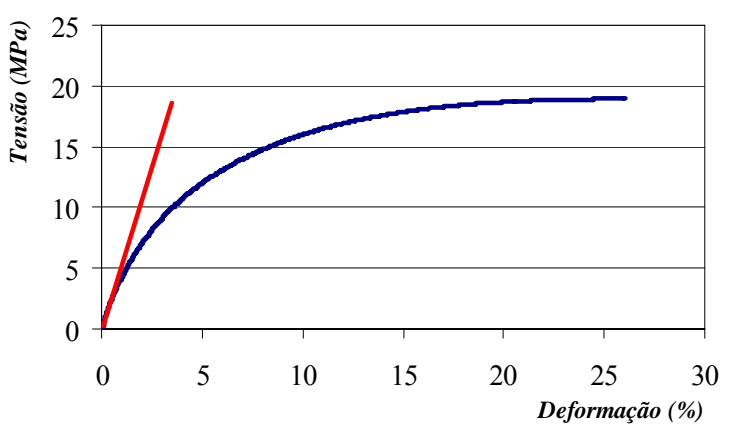

$\mathrm{CP} 3$

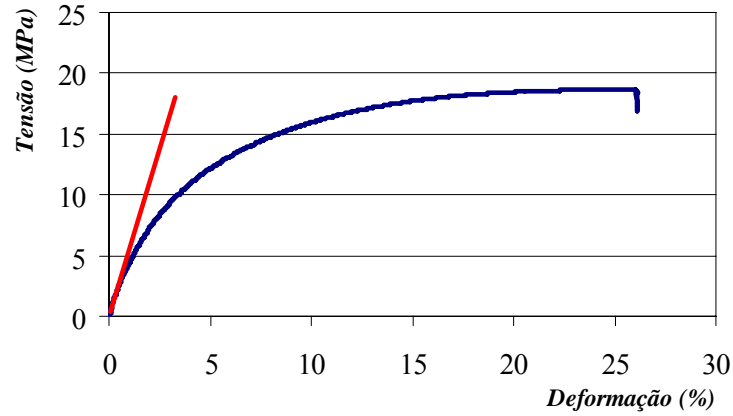

$\mathrm{CP} 2$

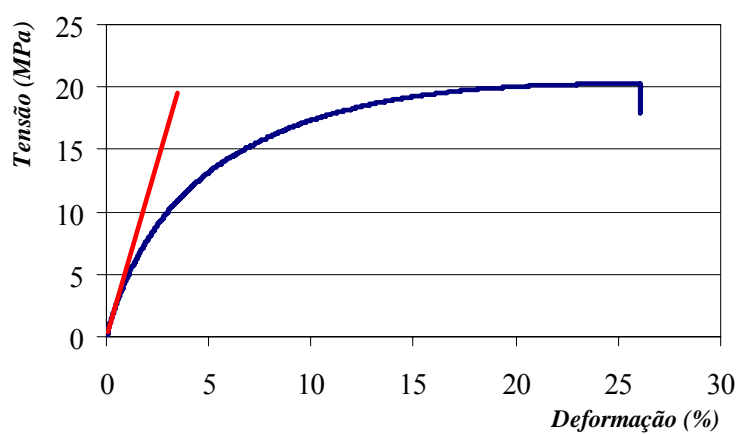

$\mathrm{CP} 4$

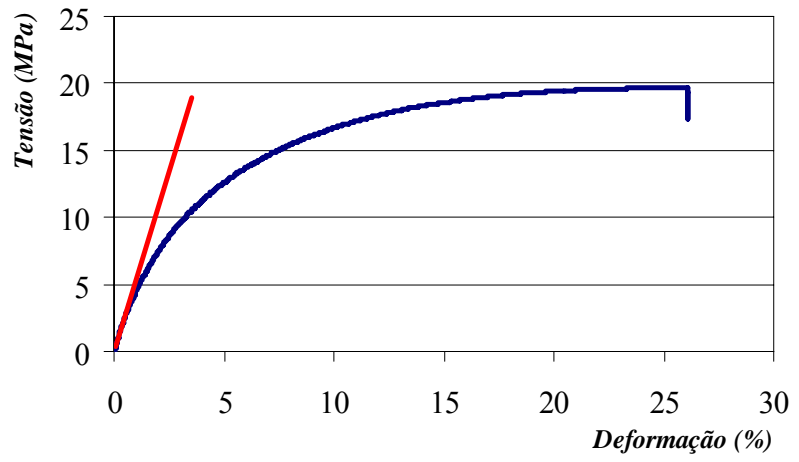

CP5

Figura B.7: Curvas tensão $x$ deformação obtidas para os corpos-de-prova de tração verdes, ensaiados com extensômetro.

As curvas tensão $x$ deformação obtidas para os cinco corpos-de-prova de PEAD com colorações branca e verde estão ilustradas nas figuras B.8 e B.9. Esses corpos-de-prova foram submetidos à velocidade de $50 \mathrm{~mm} / \mathrm{min}$, para obter tensão e deformação no escoamento, tensão e deformação na ruptura e elongação. 


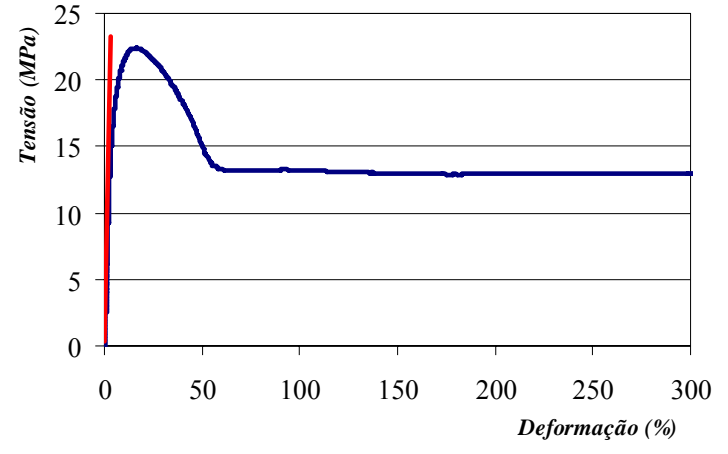

$\mathrm{CP} 1$

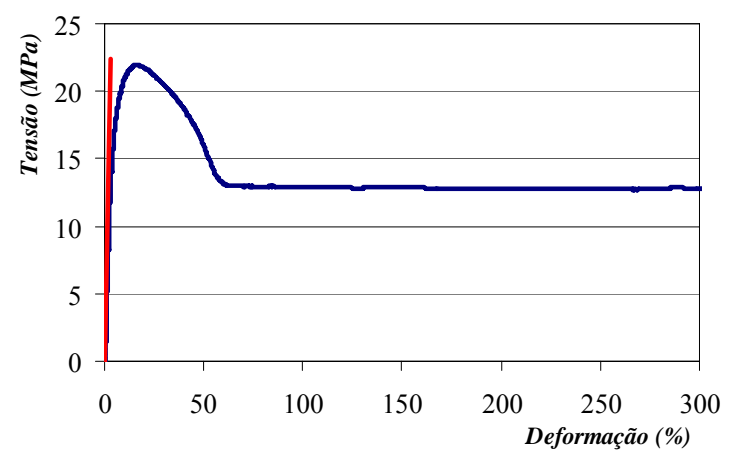

CP3

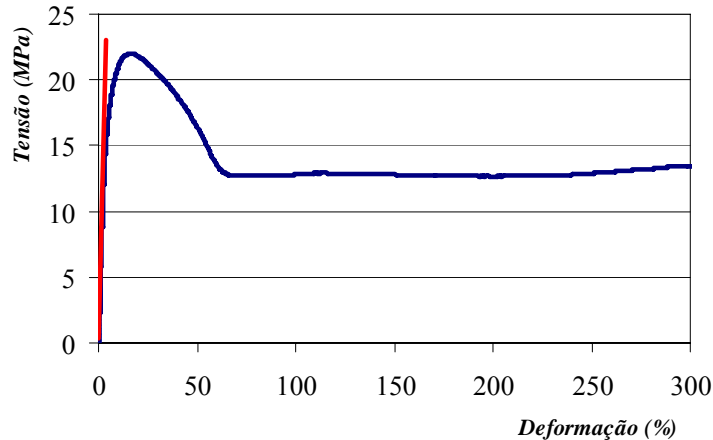

$\mathrm{CP} 2$

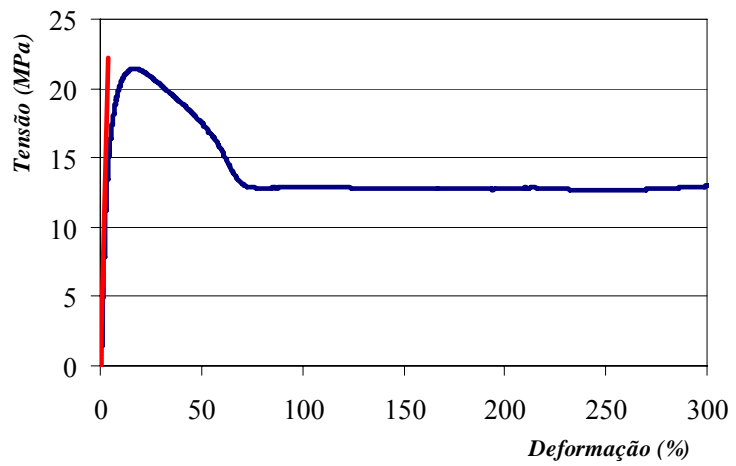

$\mathrm{CP} 4$

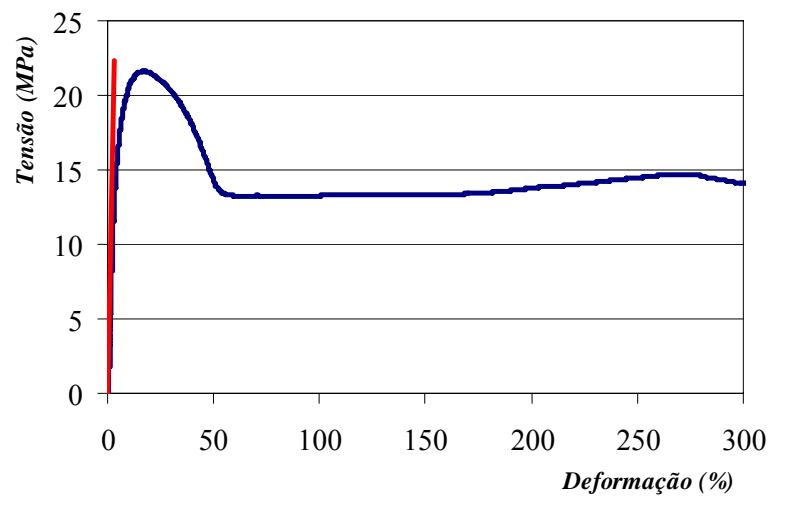

CP5

Figura B.8: Curvas tensão $x$ deformação obtidas para os corpos-de-prova de tração brancos, ensaiados com transdutor indutivo de deslocamento. 


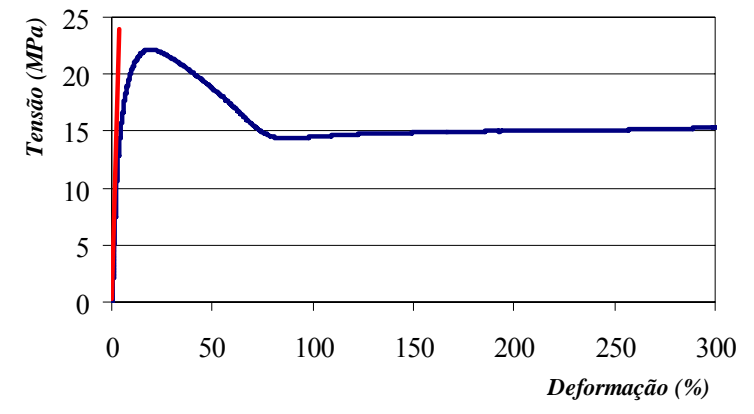

$\mathrm{CP} 1$

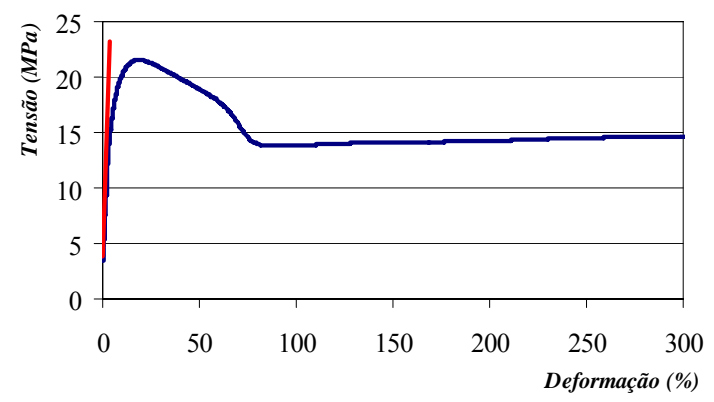

CP3

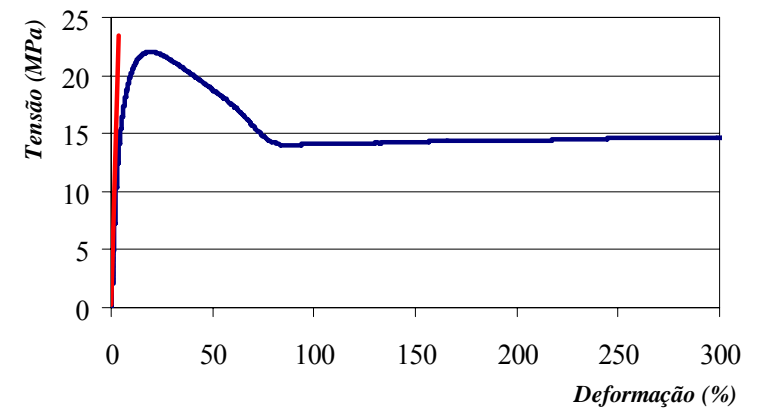

$\mathrm{CP} 2$

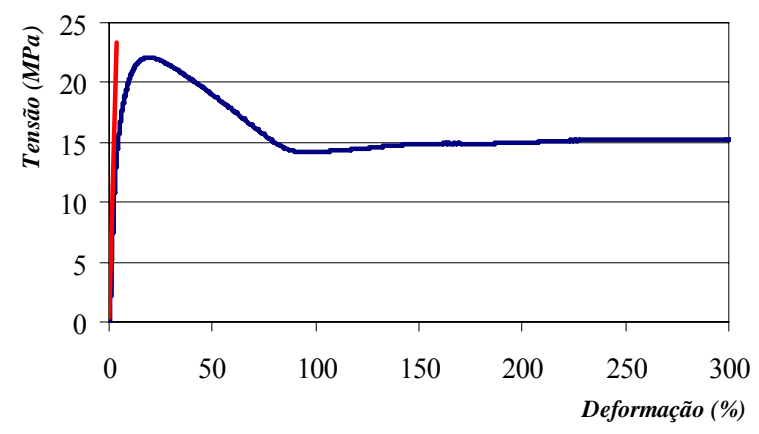

$\mathrm{CP} 4$

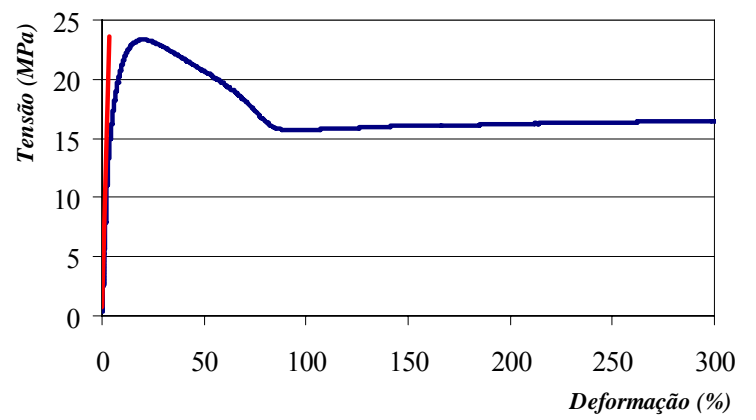

CP5

Figura B.9: Curvas tensão $x$ deformação obtidas para os corpos-de-prova de tração verdes, ensaiados com transdutor indutivo de deslocamento.

Os resultados do ensaio de tração estão ilustrados nas tabelas B.1 e B.2. 
Tabela B.1: Resultados dos corpos-de-prova brancos submetidos à tração.

\begin{tabular}{cccccc}
\hline \multirow{2}{*}{ Propriedades } & \multicolumn{5}{c}{ Corpos-de-Prova Brancos } \\
\cline { 2 - 6 } & CP1 & CP2 & CP3 & CP4 & CP5 \\
\hline $\begin{array}{c}\text { Resistência no escoamento (MPa) } \\
\text { (tensão máxima) }\end{array}$ & 22,37 & 21,97 & 21,92 & 21,40 & 21,60 \\
\hline $\begin{array}{c}\text { Deformação no escoamento } \\
\text { (mm/mm) }\end{array}$ & 0,169 & 0,171 & 0,159 & 0,161 & 0,179 \\
\hline Tensão na ruptura (MPa) & 14,09 & 13,94 & 13,98 & 14,07 & 14,64 \\
\hline Deformação na ruptura (mm/mm) & 6,53 & 6,36 & 6,53 & 6,78 & 6,51 \\
\hline Elongação percentual (\%) & 653 & 636 & 653 & 678 & 651 \\
\hline $\begin{array}{c}\text { Módulo de elasticidade tangente* } \\
\text { (MPa) }\end{array}$ & 600 & 589 & 596 & 595 & 610 \\
\hline
\end{tabular}

* Única propriedade obtida com velocidade de deslocamento de $5 \mathrm{~mm} / \mathrm{min}$. As demais foram obtidas com velocidade de $50 \mathrm{~mm} / \mathrm{min}$.

Tabela B.2: Resultados dos corpos-de-prova verdes submetidos à tração.

\begin{tabular}{cccccc}
\hline Propriedades & \multicolumn{5}{c}{ Corpos-de-Prova Verdes } \\
\cline { 2 - 6 } & CP1 & CP2 & CP3 & CP4 & CP5 \\
\hline $\begin{array}{c}\text { Resistência no escoamento (MPa) } \\
\text { (tensão máxima) }\end{array}$ & 22,16 & 22,03 & 21,55 & 22,10 & 23,34 \\
\hline $\begin{array}{c}\text { Deformação no escoamento } \\
\text { (mm/mm) }\end{array}$ & 0,20 & 0,19 & 0,18 & 0,21 & 0,20 \\
\hline Tensão na ruptura (MPa) & 15,21 & 14,92 & 14,14 & 16,17 & 16,38 \\
\hline Deformação na ruptura (mm/mm) & 2,35 & 4,54 & 3,31 & 9,41 & 2,31 \\
\hline Elongação percentual (\%) & 235 & 454 & 331 & 941 & 231 \\
\hline $\begin{array}{c}\text { Módulo de elasticidade tangente* } \\
\text { (MPa) }\end{array}$ & 562 & 543 & 536 & 555 & 537 \\
\hline
\end{tabular}

* Única propriedade obtida com velocidade de deslocamento de $5 \mathrm{~mm} / \mathrm{min}$. As demais foram obtidas com velocidade de $50 \mathrm{~mm} / \mathrm{min}$.

\section{B.3- ENSAIO DE COMPRESSÃO}

As curvas tensão $x$ deformação obtidas para os dez corpos-de-prova de PEAD com colorações branca e verde estão ilustradas nas figuras B.10 e B.11. Esses corpos-de-prova foram submetidos à velocidade de deslocamento de $1,3 \mathrm{~mm} / \mathrm{min}$, para obter a resistência, a tensão e deformação no escoamento, a tensão de escoamento deslocada e o módulo de elasticidade. 


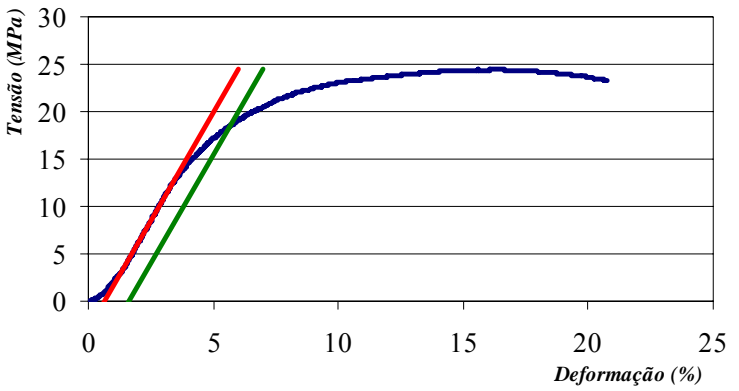

CP 1

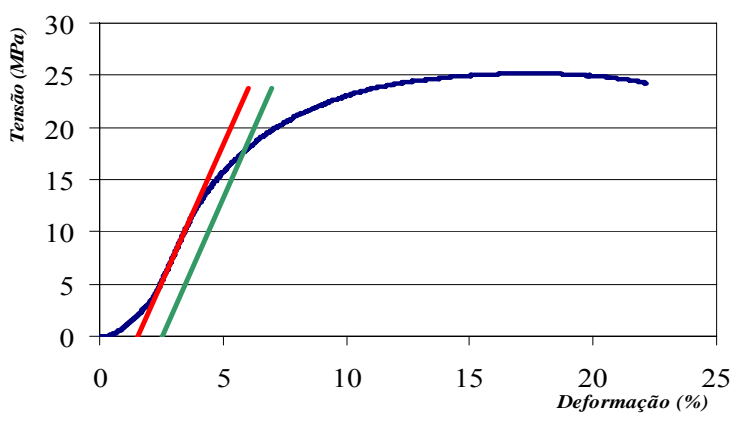

CP 3

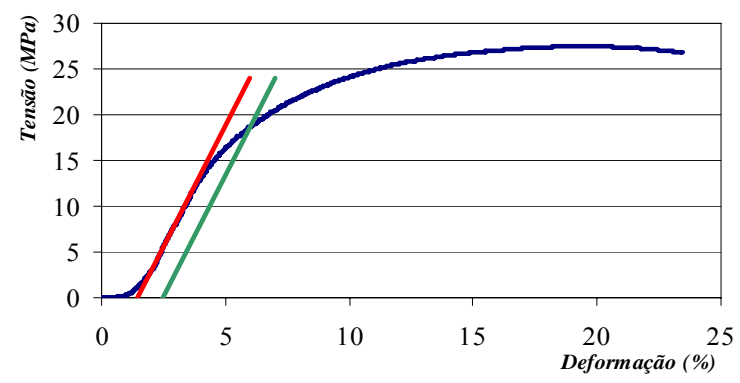

CP 5

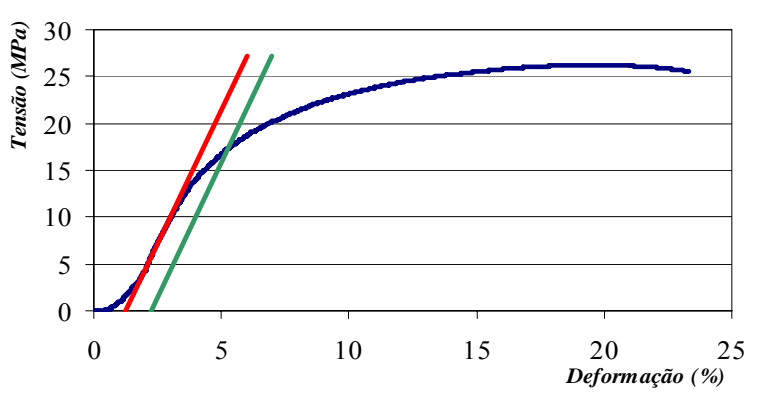

CP 7

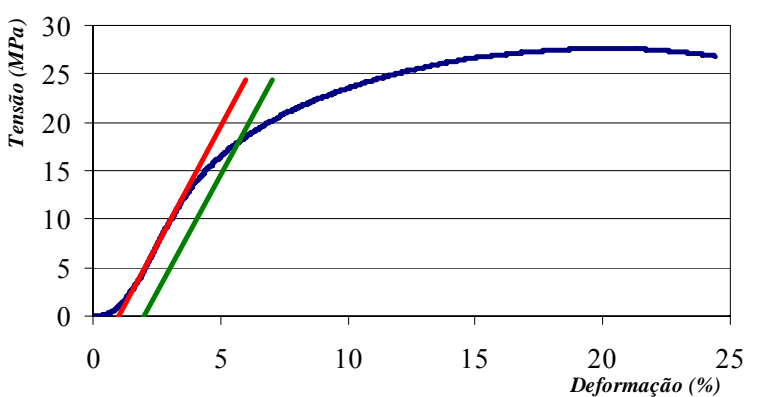

CP 2

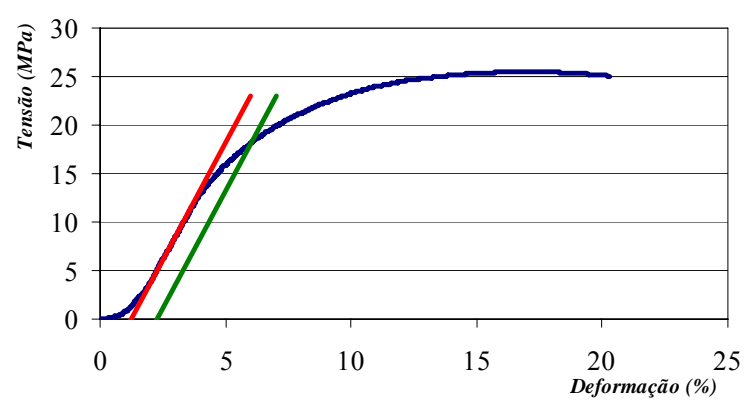

CP 4

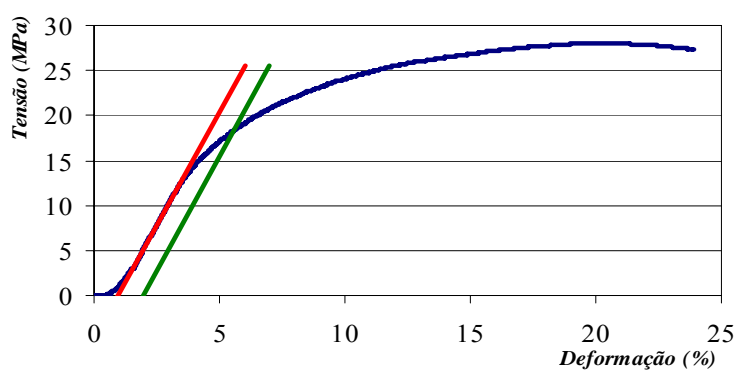

CP 6

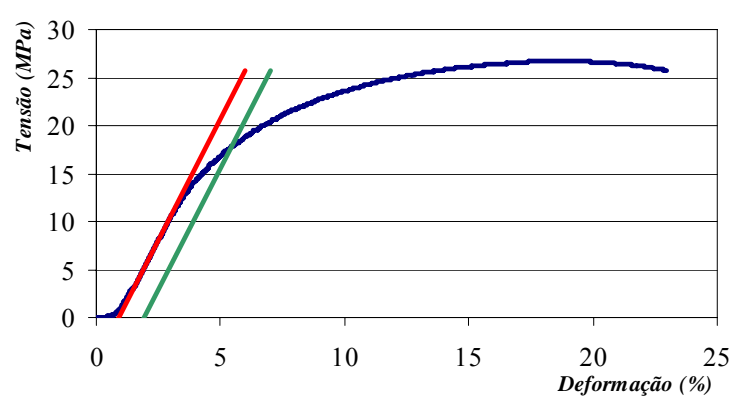

CP 8 


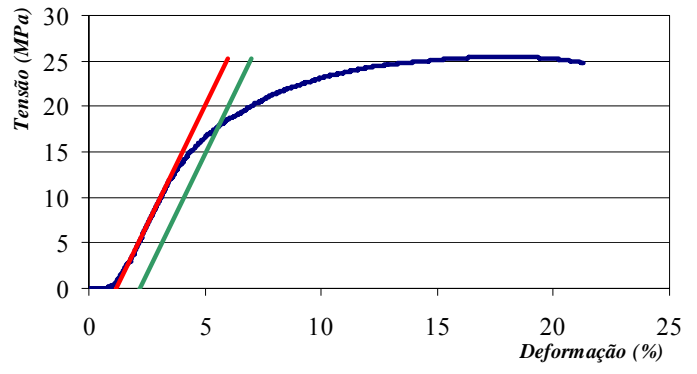

CP 9

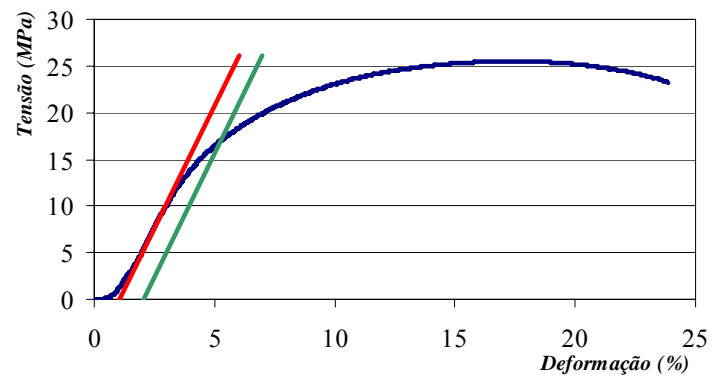

CP 10

Figura B.10: Curvas tensão $x$ deformação obtidas para os corpos-de-prova de compressão brancos.

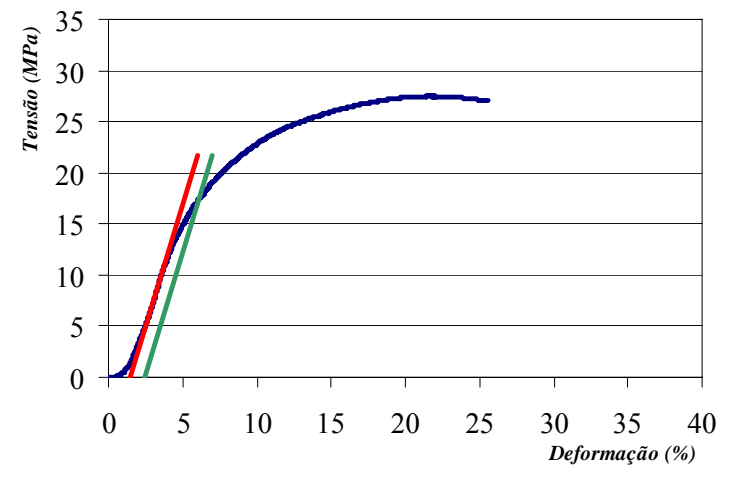

CP 1

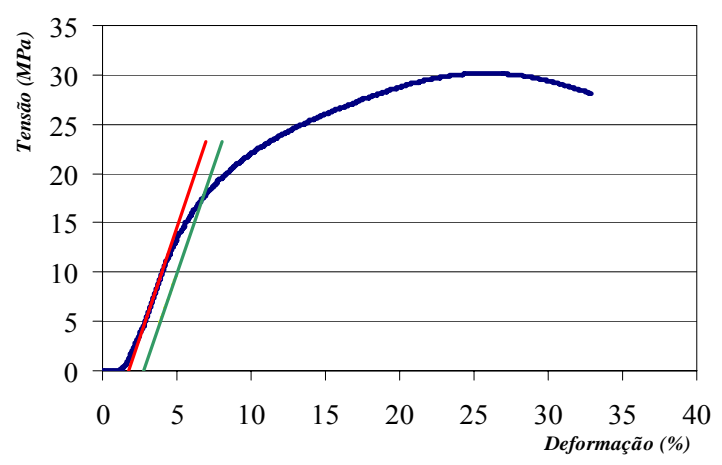

CP 3

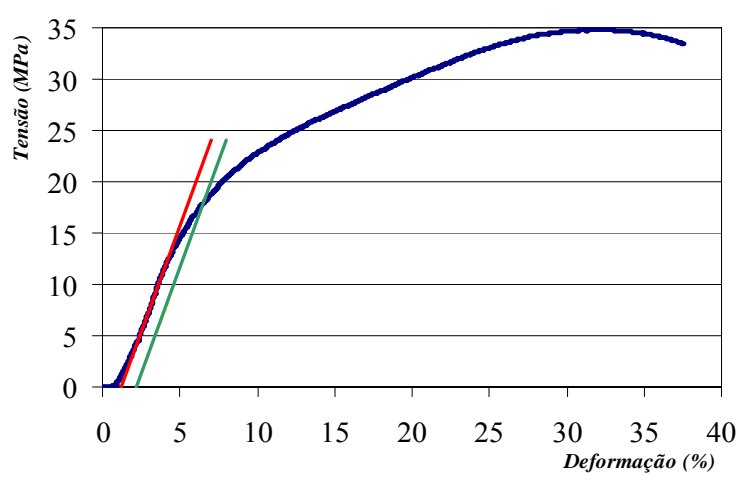

CP 5

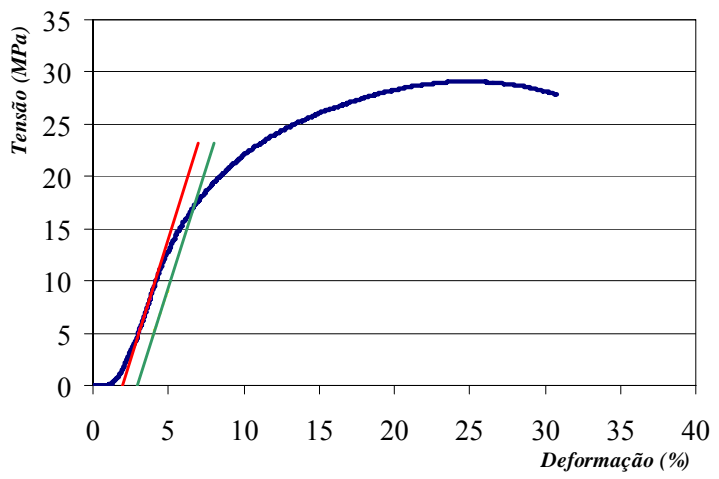

CP 2

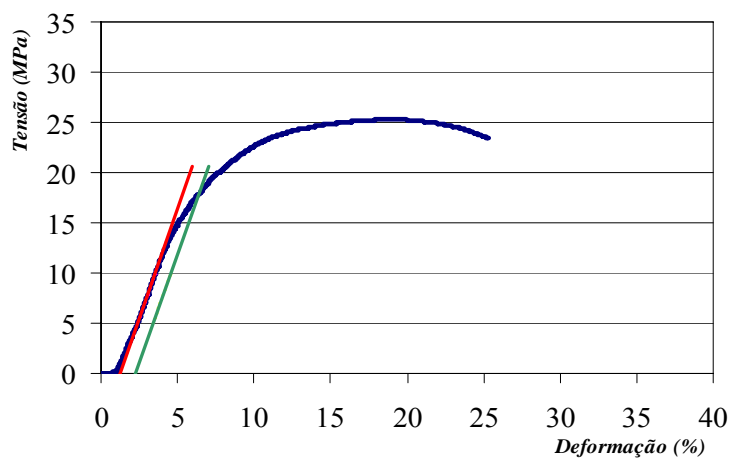

CP 4

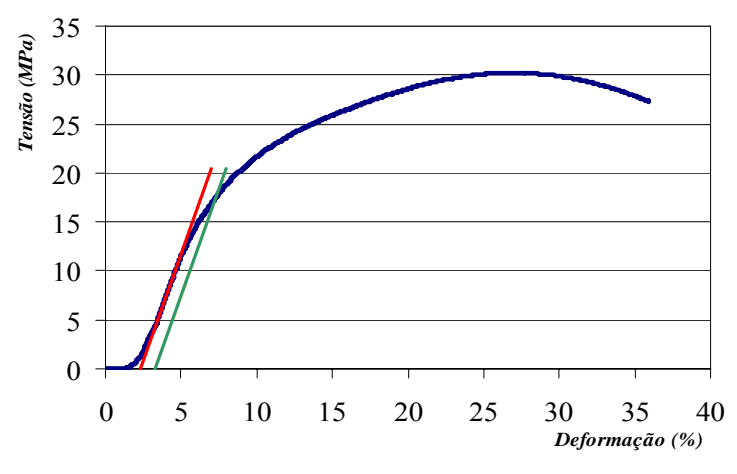

CP 6 


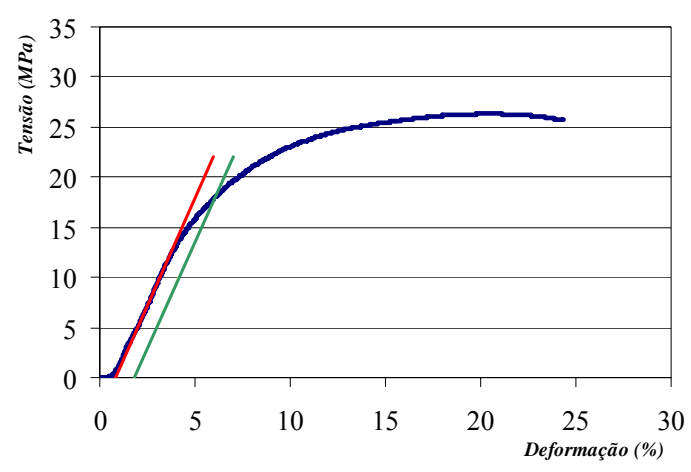

CP 7

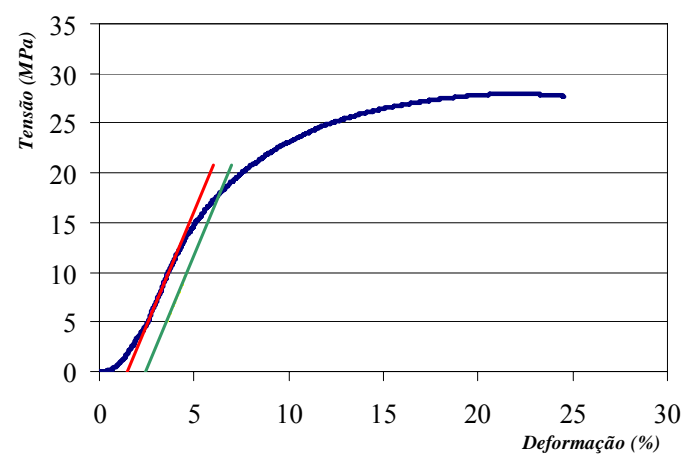

CP 9

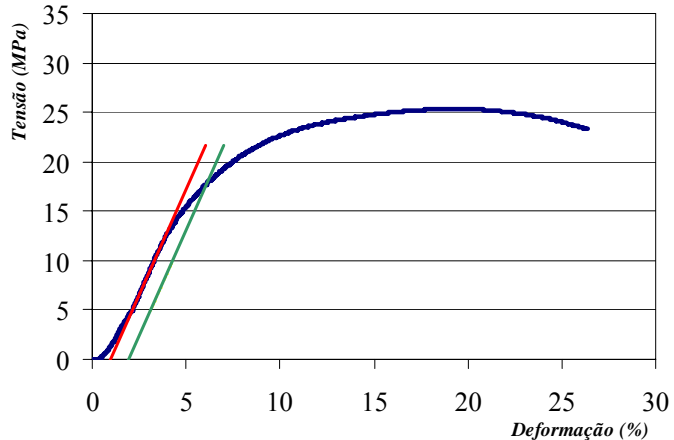

CP 8

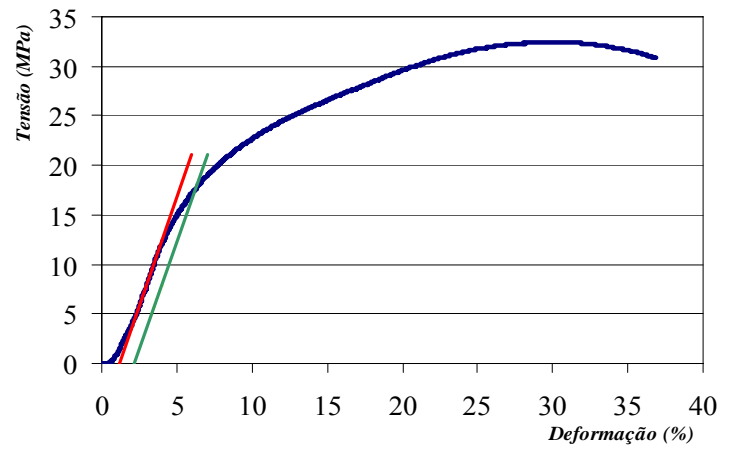

CP 10

Figura B.11: Curvas tensão $x$ deformação obtidas para os corpos-de-prova de compressão verdes.

O módulo de elasticidade é dado pelo coeficiente angular da reta vermelha, tangente traçada na parte linear da curva. A tensão de escoamento deslocada é dada pelo cruzamento da curva tensão $x$ deformação com a reta verde, que está deslocada $1 \%$, paralelamente à reta vermelha.

Os resultados dos ensaios de compressão para os PEAD de colorações branca e verde estão apresentados nas tabelas B.3 e B.4, respectivamente. 
Tabela B.3: Resultados dos corpos-de-prova brancos submetidos à compressão.

\begin{tabular}{cccccc}
\hline $\begin{array}{c}\text { Corpos- } \\
\text { de-Prova } \\
\text { Brancos }\end{array}$ & $\begin{array}{c}\text { Resistência } \\
\text { (MPa) }\end{array}$ & $\begin{array}{c}\text { Tensão no } \\
\text { escoamento } \\
\text { (MPa) }\end{array}$ & $\begin{array}{c}\text { Deformação no } \\
\text { escoamento } \\
\text { (mm/mm) }\end{array}$ & $\begin{array}{c}\text { Tensão de } \\
\text { escoamento } \\
\text { deslocada } \\
\text { (MPa) }\end{array}$ & $\begin{array}{c}\text { Módulo de } \\
\text { elasticidade } \\
\text { (MPa) }\end{array}$ \\
\hline CP 1 & 24,42 & 12,85 & 0,035 & 16,01 & 337 \\
\hline CP 2 & 27,61 & 13,85 & 0,040 & 16,55 & 311 \\
\hline CP 3 & 25,18 & 14,79 & 0,047 & 17,35 & 270 \\
\hline CP 4 & 25,50 & 14,66 & 0,045 & 17,24 & 277 \\
\hline CP 5 & 27,44 & 14,98 & 0,045 & 17,75 & 281 \\
\hline CP 6 & 28,01 & 14,25 & 0,039 & 17,01 & 314 \\
\hline CP 7 & 26,21 & 13,74 & 0,039 & 16,51 & 297 \\
\hline CP 8 & 26,72 & 14,25 & 0,040 & 16,89 & 317 \\
\hline CP 9 & 25,46 & 14,13 & 0,041 & 16,83 & 296 \\
\hline CP 10 & 25,49 & 13,61 & 0,039 & 16,30 & 303 \\
\hline
\end{tabular}

Tabela B.4: Resultados dos corpos-de-prova verdes submetidos à compressão.

\begin{tabular}{cccccc}
\hline $\begin{array}{c}\text { Corpos- } \\
\text { de-Prova } \\
\text { Verdes }\end{array}$ & $\begin{array}{c}\text { Resistência } \\
\text { (MPa) }\end{array}$ & $\begin{array}{c}\text { Tensão no } \\
\text { escoamento } \\
\text { (MPa) }\end{array}$ & $\begin{array}{c}\text { Deformação no } \\
\text { escoamento } \\
(\mathbf{m m} / \mathbf{m m})\end{array}$ & $\begin{array}{c}\text { Tensão de } \\
\text { escoamento } \\
\text { deslocada } \\
\text { (MPa) }\end{array}$ & $\begin{array}{c}\text { Módulo de } \\
\text { elasticidade } \\
\text { (MPa) }\end{array}$ \\
\hline CP 1 & 27,49 & 14,15 & 0,047 & 16,62 & 251 \\
\hline CP 2 & 29,11 & 14,62 & 0,056 & 16,91 & 210 \\
\hline CP 3 & 30,13 & 14,33 & 0,053 & 16,67 & 210 \\
\hline CP 4 & 25,30 & 14,86 & 0,050 & 17,23 & 261 \\
\hline CP 5 & 32,92 & 13,55 & 0,046 & 16,08 & 245 \\
\hline CP 6 & 30,22 & 16,10 & 0,066 & 18,22 & 186 \\
\hline CP 7 & 26,30 & 13,46 & 0,041 & 16,13 & 292 \\
\hline CP 8 & 25,34 & 13,28 & 0,042 & 15,91 & 285 \\
\hline CP 9 & 27,98 & 14,67 & 0,049 & 17,11 & 249 \\
\hline CP 10 & 32,41 & 13,44 & 0,044 & 16,02 & 269 \\
\hline
\end{tabular}

\section{B.4- ENSAIO DE FLEXÃO}

As curvas tensão $x$ deformação obtidas para os 10 corpos-de-prova de PEAD de colorações branca e verde estão ilustradas nas figuras B.12 e B.13. Esses corpos-de-prova foram submetidos à velocidade de deslocamento de $2,8 \mathrm{~mm} / \mathrm{min}$, para obter a força máxima e a resistência correspondente a 5\% de deformação e o módulo de elasticidade. 


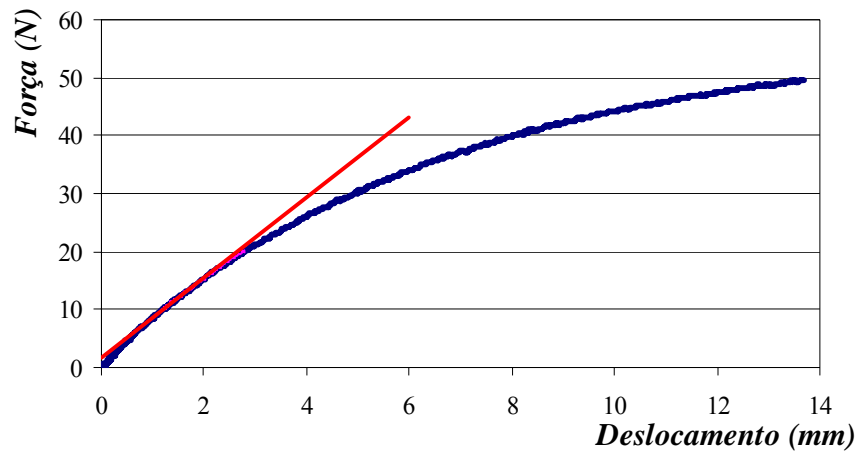

CP 1

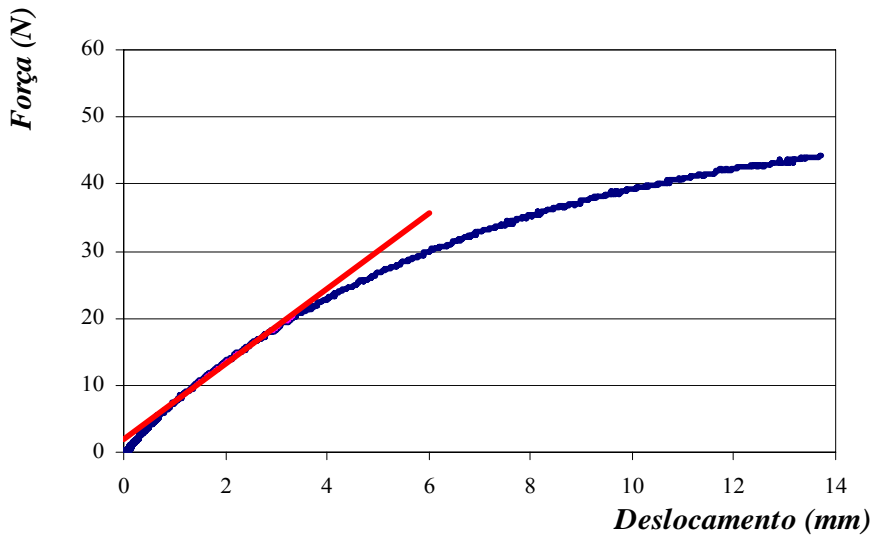

CP 2

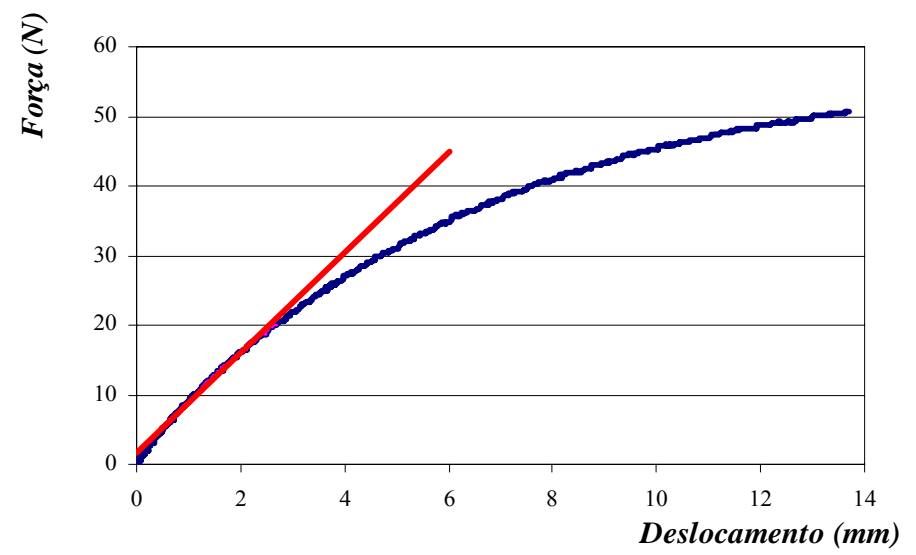

CP 3 


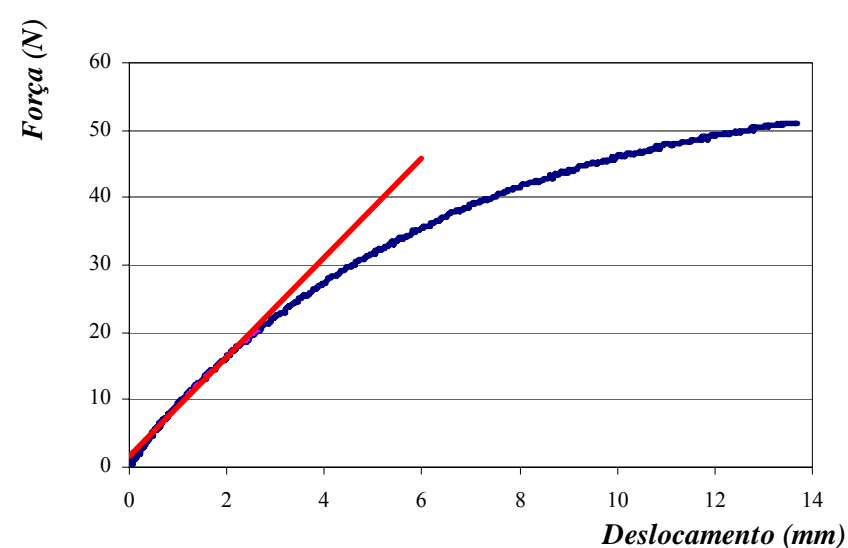

CP 4

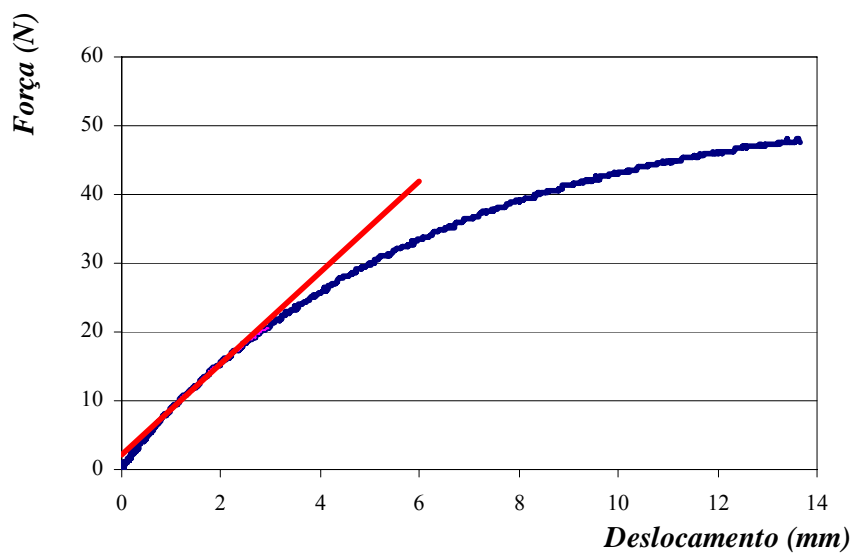

CP 5

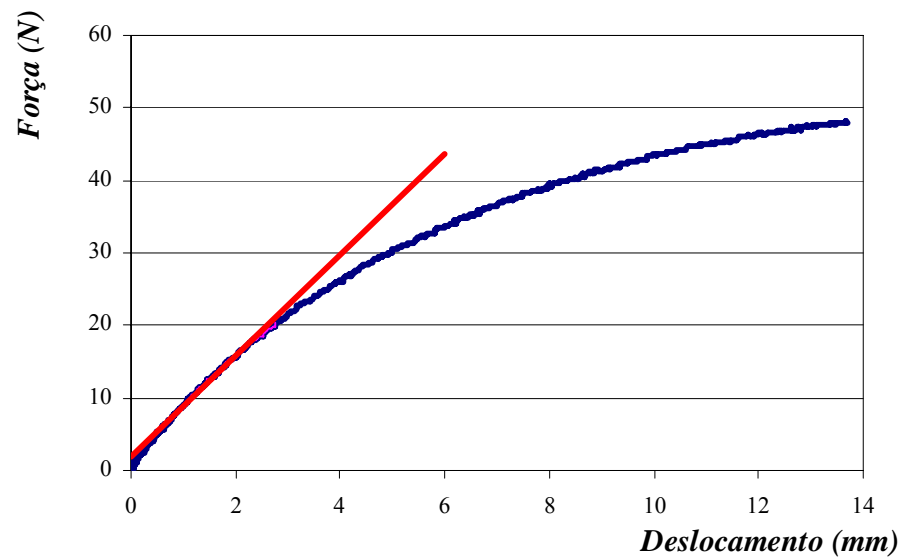

CP 6 


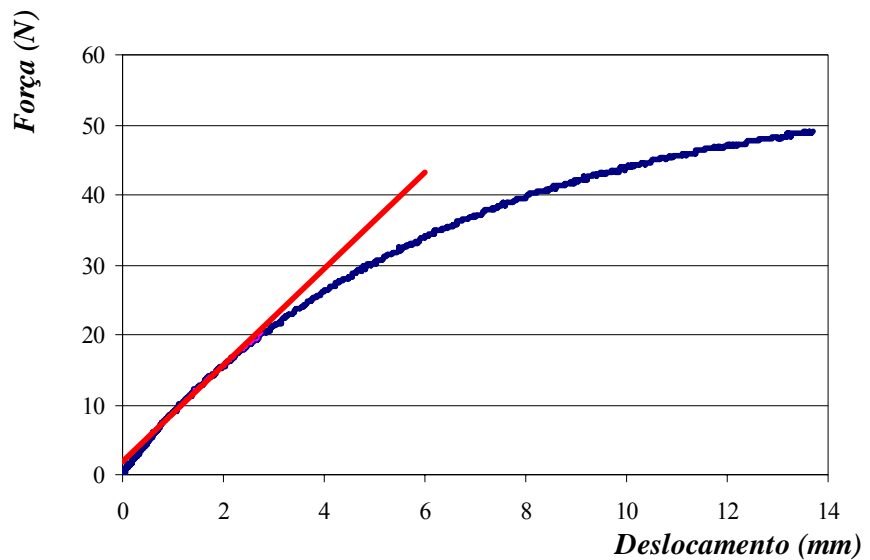

CP 7

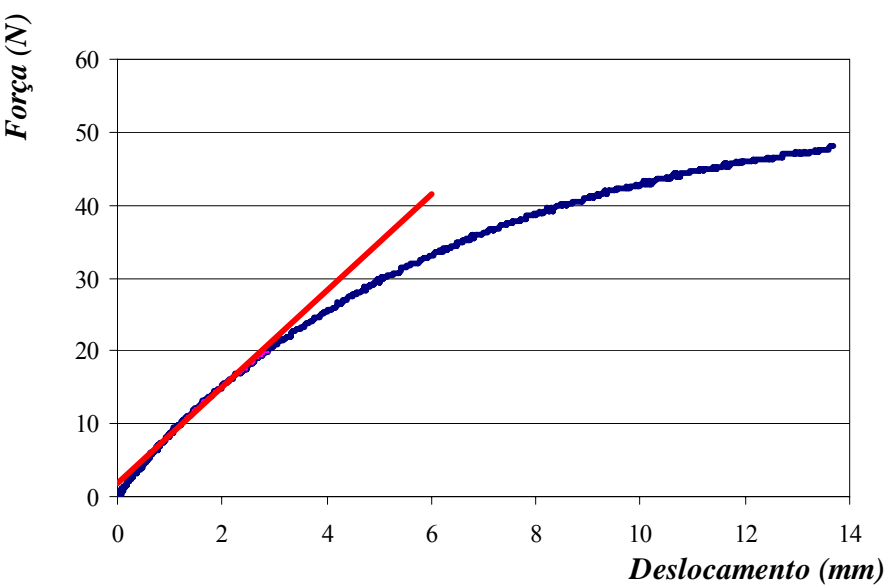

CP 8

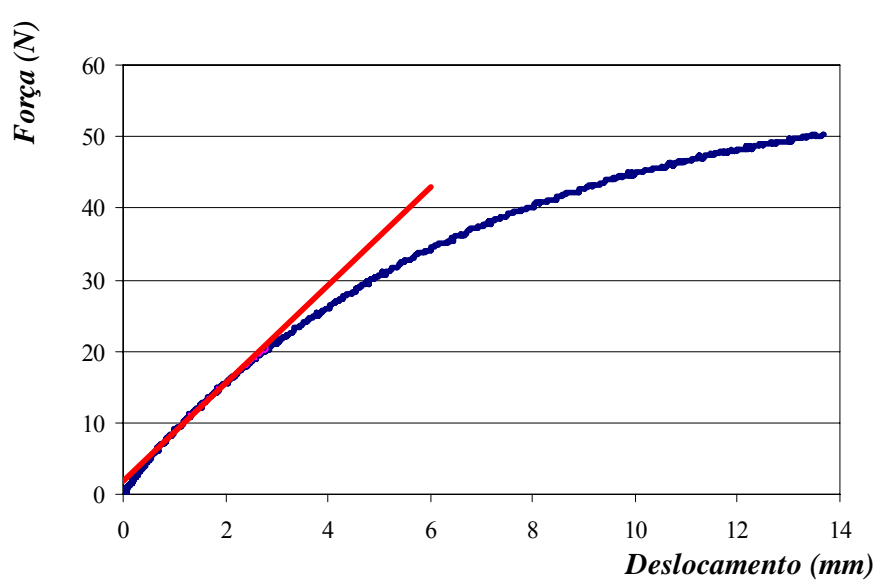

CP 9 


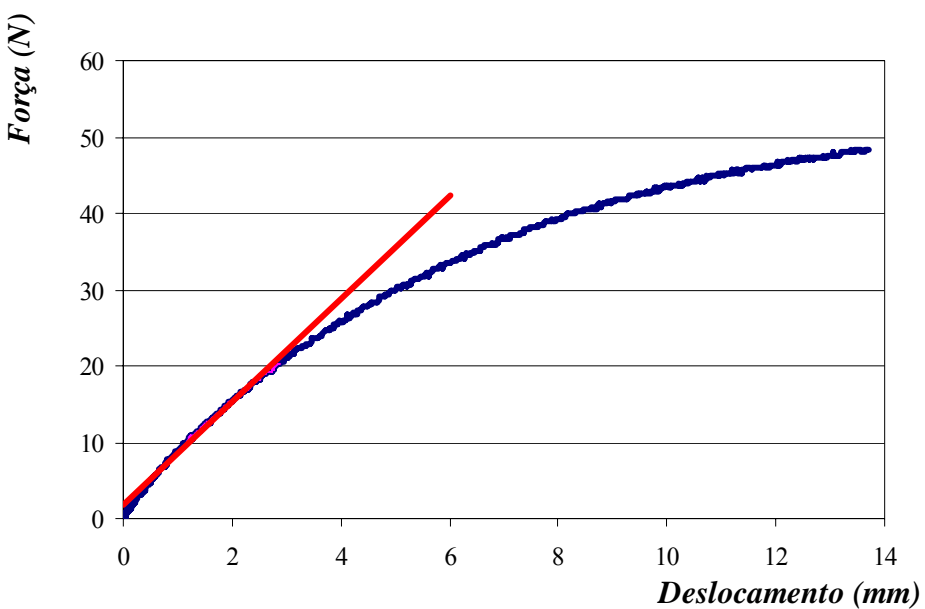

CP 10

Figura B.12: Curvas força $x$ deslocamento obtidas para os corpos-de-prova de flexão brancos.

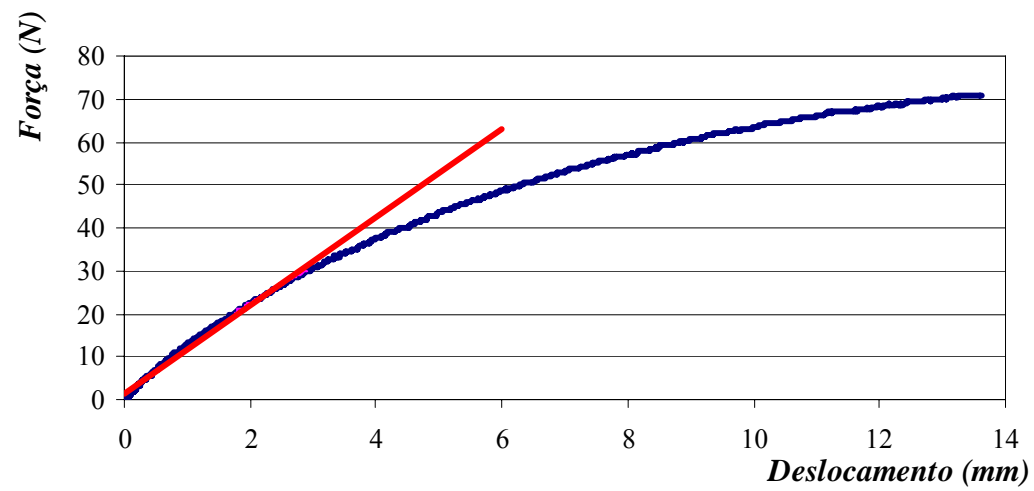

CP 1

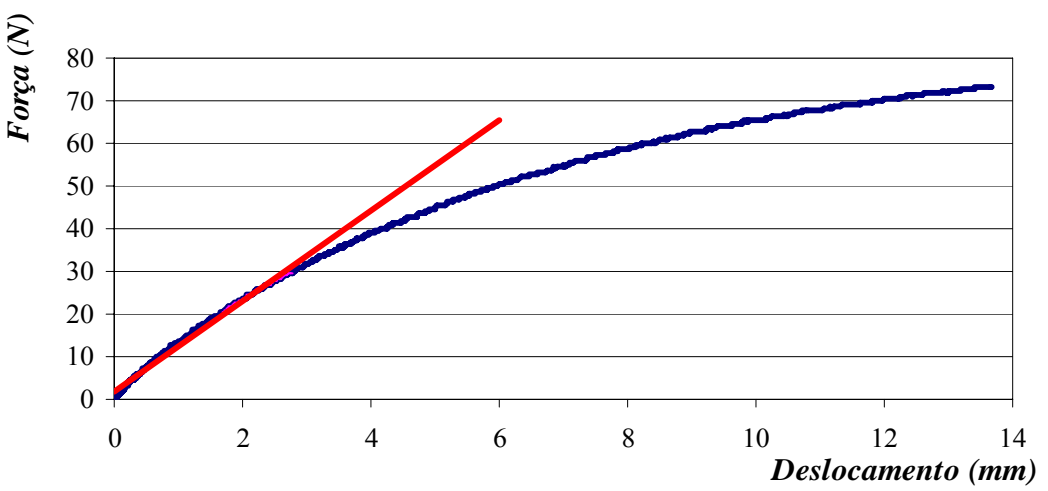

CP 2 


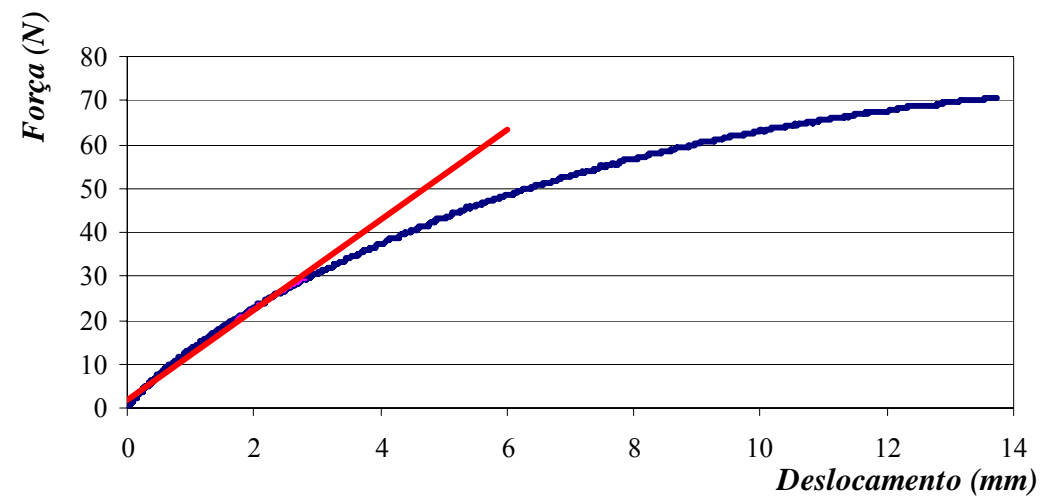

CP 3

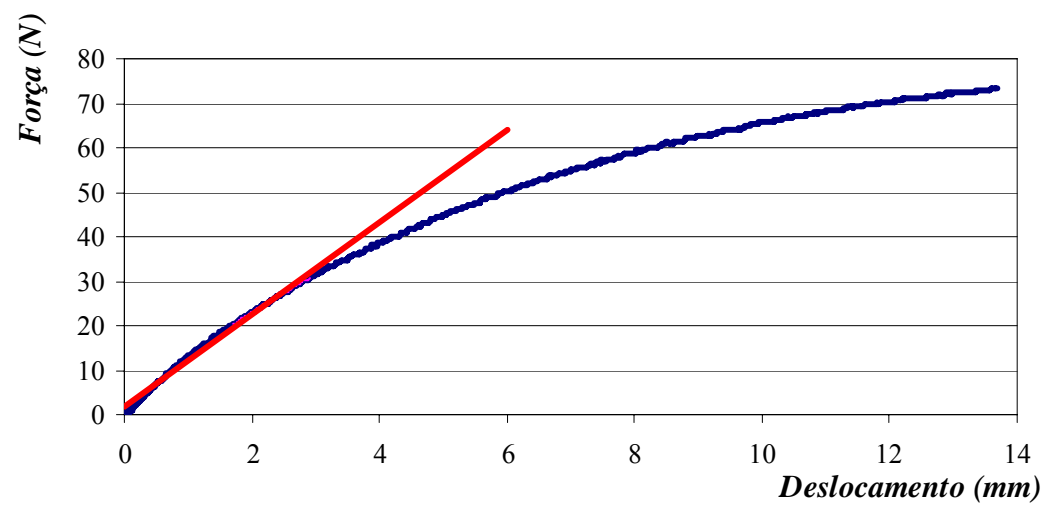

CP 4

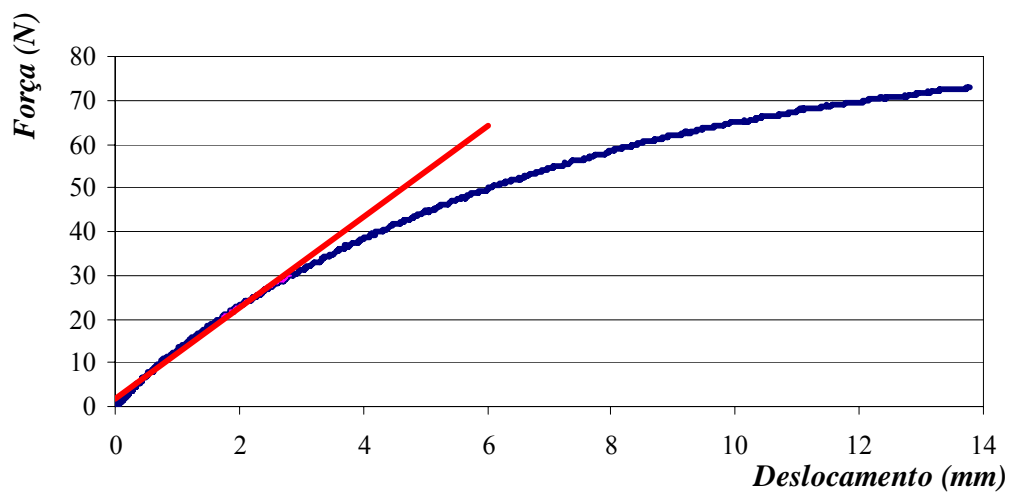

CP 5 


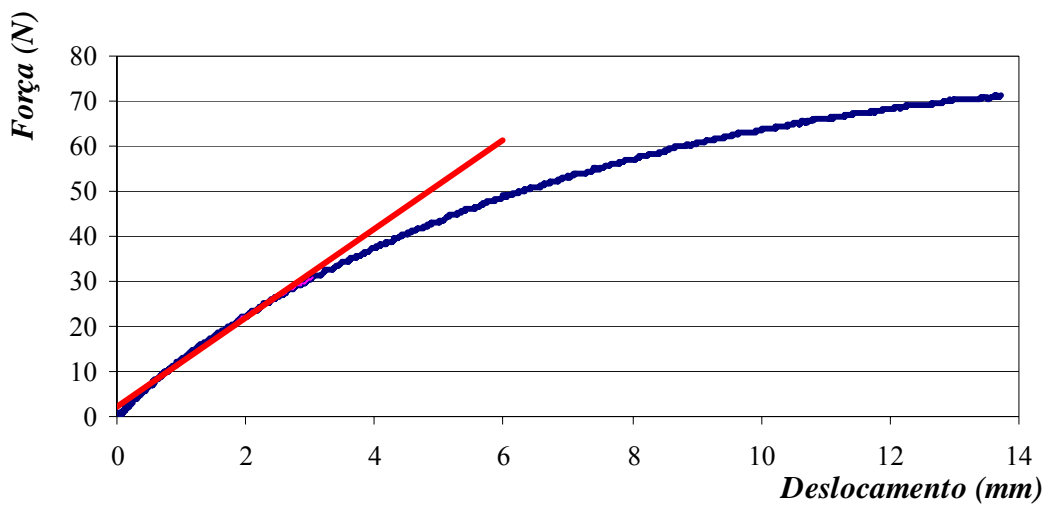

CP 6

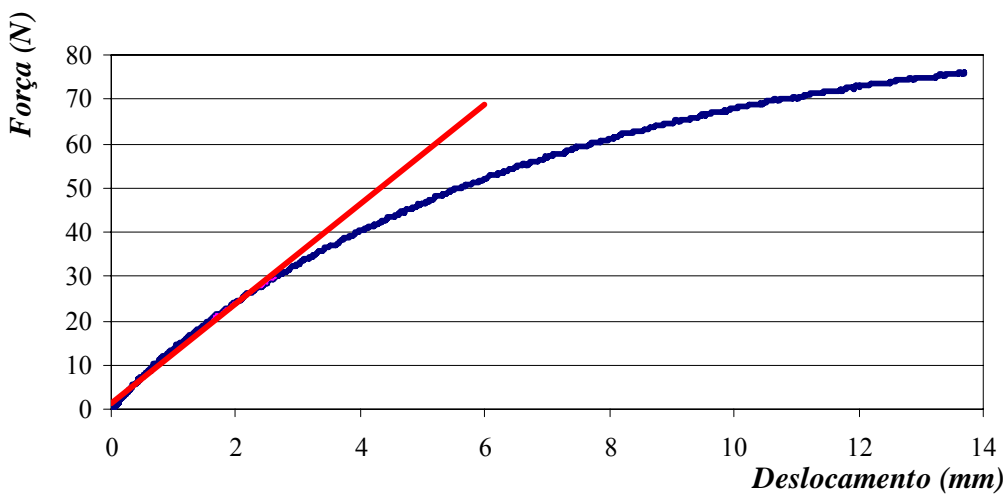

CP 7

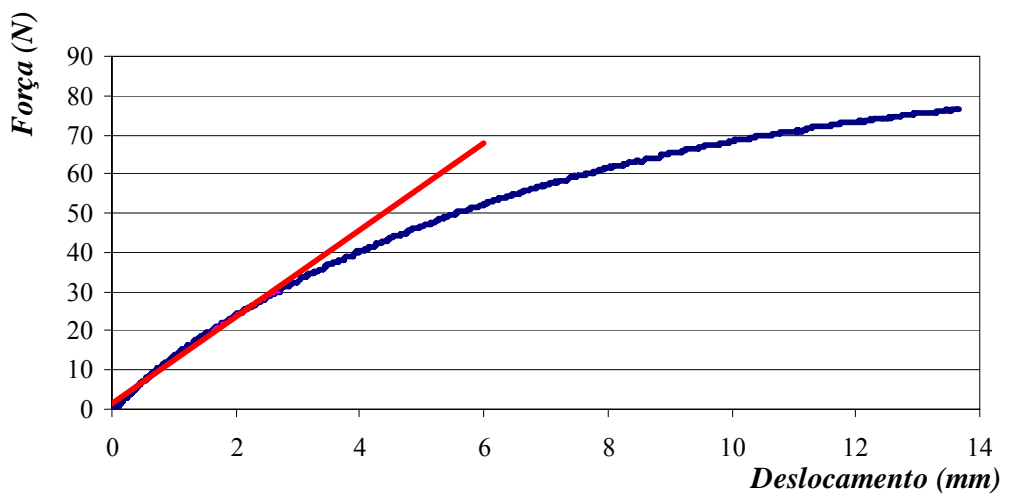

CP 8 


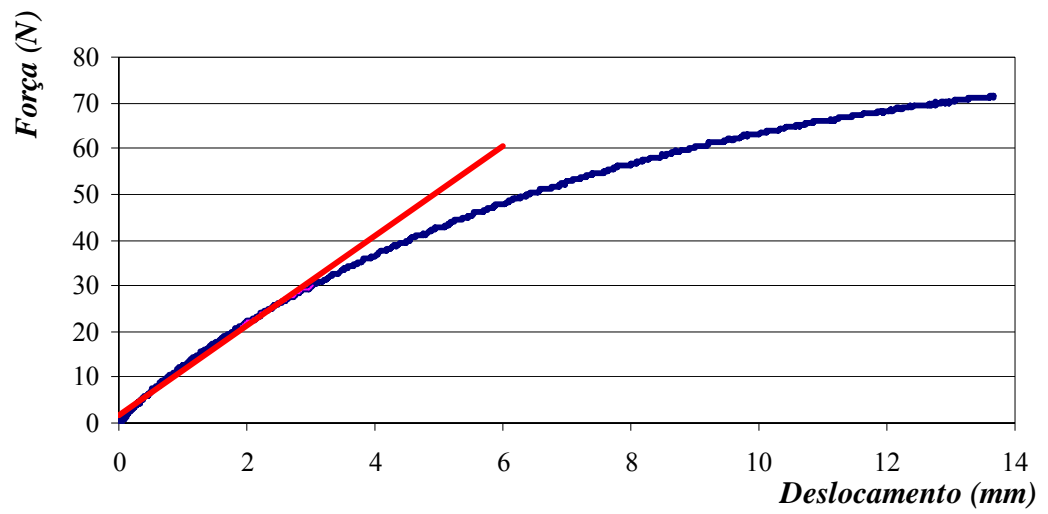

CP 9

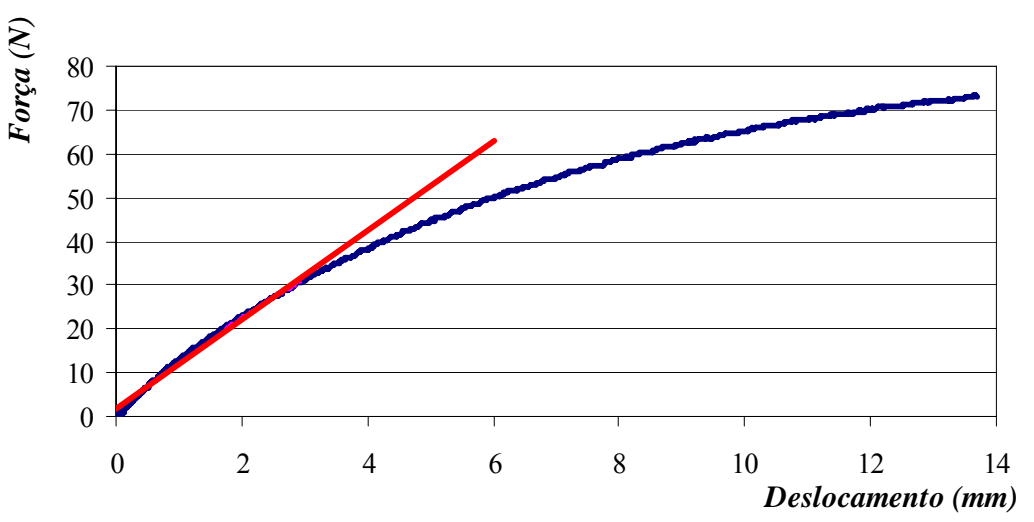

CP 10

Figura B.13: Curvas força $x$ deslocamento obtidas para os corpos-de-prova de flexão verdes.

A reta vermelha representa a tangente traçada na parte linear da curva força $x$ deslocamento.

Os resultados dos ensaios de flexão para os PEAD de coloração branca e verde estão apresentados nas tabelas B.5 e B.6, respectivamente. 
Tabela B.5: Resultados dos corpos-de-prova brancos submetidos à flexão.

\begin{tabular}{cccc}
\hline $\begin{array}{c}\text { Corpos-de- } \\
\text { Prova } \\
\text { Brancos }\end{array}$ & $\begin{array}{c}\text { Força máxima } \\
\text { correspondente a 5\% } \\
\text { de deformação (N) }\end{array}$ & $\begin{array}{c}\text { Resistência } \\
\text { correspondente a } \\
\text { 5\% deformação } \\
\text { (MPa) }\end{array}$ & $\begin{array}{c}\text { Módulo de } \\
\text { Elasticidade } \\
\text { Tangente (MPa) }\end{array}$ \\
\hline CP 1 & 49 & 17,86 & 799 \\
\hline CP 2 & 44 & 17,73 & 787 \\
\hline CP 3 & 50 & 17,41 & 784 \\
\hline CP 4 & 51 & 18,15 & 840 \\
\hline CP 5 & 48 & 16,83 & 765 \\
\hline CP 6 & 48 & 17,56 & 844 \\
\hline CP 7 & 49 & 17,89 & 824 \\
\hline CP 8 & 48 & 17,63 & 794 \\
\hline CP 9 & 50 & 17,79 & 804 \\
\hline CP 10 & 48 & 17,51 & \\
\hline
\end{tabular}

Tabela B.6: Resultados dos corpos-de-prova verdes submetidos à flexão.

\begin{tabular}{cccc}
\hline $\begin{array}{c}\text { Corpos-de- } \\
\text { Prova Verdes }\end{array}$ & $\begin{array}{c}\text { Força máxima } \\
\text { correspondente a 5\% } \\
\text { de deformação (N) }\end{array}$ & $\begin{array}{c}\text { Resistência } \\
\text { correspondente a } \\
\mathbf{5 \%} \text { de deformação } \\
\text { (MPa) }\end{array}$ & $\begin{array}{c}\text { Módulo de } \\
\text { Elasticidade } \\
\text { Tangente (MPa) }\end{array}$ \\
\hline CP 1 & 71 & 18,47 & 713 \\
\hline CP 2 & 73 & 18,92 & 745 \\
\hline CP 3 & 70 & 18,21 & 718 \\
\hline CP 4 & 73 & 18,49 & 704 \\
\hline CP 5 & 73 & 18,89 & 727 \\
\hline CP 6 & 71 & 18,58 & 711 \\
\hline CP 7 & 76 & 19,33 & 728 \\
\hline CP 8 & 76 & 19,07 & 671 \\
\hline CP 9 & 71 & 18,29 & 724 \\
\hline CP 10 & 73 & 19,05 & \\
\hline
\end{tabular}




\section{B.5- ENSAIO DE IMPACTO}

Os resultados dos ensaios de impacto para os PEAD de coloração branca e verde estão apresentados nas tabelas B.7 e B.8, respectivamente.

Tabela B.7: Resultados dos corpos-de-prova brancos submetidos ao impacto Izod.

\begin{tabular}{ccc}
\hline $\begin{array}{c}\text { Corpos-de-Prova } \\
\text { Brancos }\end{array}$ & Resistência $(\mathbf{J} / \mathbf{m})$ & Resistência $\left(\mathbf{k J} / \mathbf{m}^{2}\right)$ \\
\hline CP 1 & 141,9 & 13,68 \\
\hline CP 2 & 135,1 & 12,99 \\
\hline CP 3 & 158,9 & 15,25 \\
\hline CP 4 & 132,5 & 12,69 \\
\hline CP 5 & 133,3 & 12,75 \\
\hline CP 6 & 134,2 & 12,94 \\
\hline CP 7 & 133,8 & 12,78 \\
\hline CP 8 & 133,3 & 12,75 \\
\hline CP 9 & 139,7 & 13,35 \\
\hline CP 10 & 130,7 & 12,49 \\
\hline
\end{tabular}

Tabela B.8: Resultados dos corpos-de-prova verdes submetidos ao impacto Izod.

\begin{tabular}{ccc}
\hline $\begin{array}{c}\text { Corpos-de-Prova } \\
\text { Verdes }\end{array}$ & Resistência (J/m) & Resistência $\left(\mathbf{k J} / \mathbf{m}^{2}\right)$ \\
\hline CP 1 & 139,2 & 13,22 \\
\hline CP 2 & 131,6 & 12,25 \\
\hline CP 3 & 132,9 & 12,57 \\
\hline CP 4 & 142,8 & 13,28 \\
\hline CP 5 & 136,7 & 12,97 \\
\hline CP 6 & 136,7 & 12,72 \\
\hline CP 7 & 141,9 & 13,57 \\
\hline CP 8 & 136,3 & 12,75 \\
\hline CP 9 & 134,2 & 12,62 \\
\hline CP 10 & 139,8 & 13,16 \\
\hline
\end{tabular}

